\title{
Inclusion of autism
}

Citation for published version (APA):

van Kessel, R. (2020). Inclusion of autism: an analysis of education policy in the EU. [Doctoral Thesis, Maastricht University]. Gildeprint Drukkerijen. https://doi.org/10.26481/dis.20201210rk

\section{Document status and date:}

Published: 01/01/2020

DOI:

10.26481/dis.20201210rk

Document Version:

Publisher's PDF, also known as Version of record

\section{Please check the document version of this publication:}

- A submitted manuscript is the version of the article upon submission and before peer-review. There can be important differences between the submitted version and the official published version of record.

People interested in the research are advised to contact the author for the final version of the publication, or visit the DOI to the publisher's website.

- The final author version and the galley proof are versions of the publication after peer review.

- The final published version features the final layout of the paper including the volume, issue and page numbers.

Link to publication

\footnotetext{
General rights rights.

- You may freely distribute the URL identifying the publication in the public portal. please follow below link for the End User Agreement:

www.umlib.nl/taverne-license

Take down policy

If you believe that this document breaches copyright please contact us at:

repository@maastrichtuniversity.nl

providing details and we will investigate your claim.
}

Copyright and moral rights for the publications made accessible in the public portal are retained by the authors and/or other copyright owners and it is a condition of accessing publications that users recognise and abide by the legal requirements associated with these

- Users may download and print one copy of any publication from the public portal for the purpose of private study or research.

- You may not further distribute the material or use it for any profit-making activity or commercial gain

If the publication is distributed under the terms of Article $25 \mathrm{fa}$ of the Dutch Copyright Act, indicated by the "Taverne" license above, 


\section{Inclusion of Autism}

An Analysis of Education Policy in the EU

By Robin van Kessel 
The research for this dissertation was performed at the Department of International Health within CAPHRI, the Care and Public Health Research Institute, Faculty of Health, Medicine and Life Sciences, Maastricht University in close collaboration with the Institute of Public Health, University of Cambridge and the Autism Research Center, Department of Psychiatry, University of Cambridge.

Dissertation: Inclusion of Autism: An Analysis of Education Policy in the EU

Author: Robin van Kessel

Cover Design: Dewi Hombergen

Layout Design: Robin van Kessel

(C) Copyright: Robin van Kessel, Maastricht 2020

All rights reserved. No part of this publication may be reproduced without permission of the copyright owner.

ISBN: 978-94-641-9090-8

Printed by Gildeprint B.V. 


\section{Inclusion of Autism}

An Analysis of Education Policy in the EU

\section{DISSERTATION}

To obtain the degree of Doctor at Maastricht University, on the authority of the Rector

Magnificus Prof. dr. Rianne M. Letschert, in accordance with the decision of the Board of Deans to be defended in public on Thursday, 10 December 2020, at 12:00 hours.

by

Robin van Kessel 


\section{Supervisor}

Dr. Katarzyna Czabanowska

\section{Co-supervisor}

Dr. Andres Roman-Urrestarazu (University of Cambridge, United Kingdom)

\section{Assessment Committee}

Prof. dr. Leopold Curfs (Chair)

Prof. dr. Helmut Brand

Dr. Stavroula Kalaitzi

Prof. dr. Anastasia Vlachou (University of Thessaly, Greece)

Prof. dr. William Sherlaw (École des hautes études en santé publique [EHESP], France) 


\section{Participating Institutions}

Maastricht University

Autism Research Centre, University of Cambridge

Cambridge University Institute of Public Health

King's College London

Aarhus University

University of Oulu

University of Gothenburg

Autism-Europe

University of Malta

University of Northampton

University of Debrecen

University Hospital of L. Pasteur

Lithuanian University of Health Sciences

Riga Stradins University

University of Nottingham 


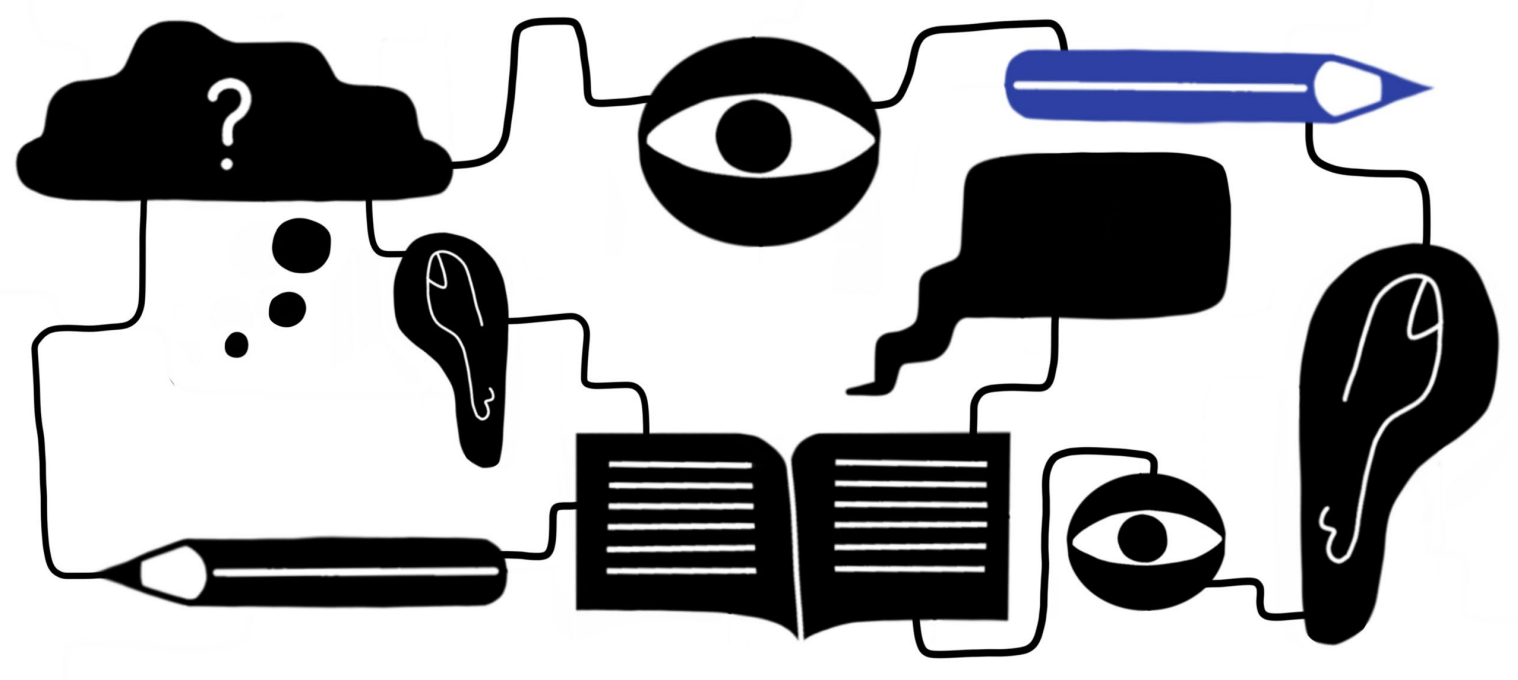

Table of Contents 
Foreword

Chapter Zero 11

$\begin{array}{ll}\text { Chapter One } & 39\end{array}$

$\begin{array}{ll}\text { Chapter Two } & 81\end{array}$

$\begin{array}{ll}\text { Chapter Three } & 121\end{array}$

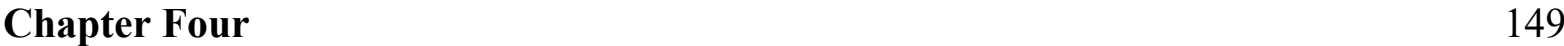

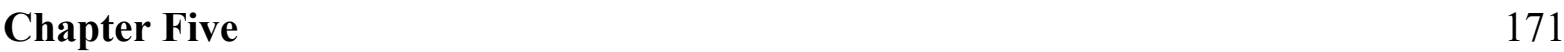

$\begin{array}{ll}\text { Chapter Six } & 199\end{array}$

Chapter Seven $\quad 223$

$\begin{array}{ll}\text { Valorization } & 233\end{array}$

$\begin{array}{ll}\text { Summary } & 251\end{array}$

$\begin{array}{ll}\text { Acknowledgements } & 255\end{array}$

$\begin{array}{ll}\text { Curriculum Vitae } & 257\end{array}$

List of Publications $\quad 259$ 


\section{Foreword}

I am proud to present my $\mathrm{PhD}$ thesis to you: "Inclusion of Autism: An Analysis of Education Policy in the EU." This work is the direct continuation of the endeavors I started during my BSc European Public Health, where I identified my passion for mental health policy, and my MSc Governance and Leadership in European Public Health, which allowed me to join the European Consortium for Autism Researchers in Education (EDUCAUS) in Cambridge. Both the BSc and MSc programs discussed various health policy issues from a comparative perspective. In the MSc placement, this skillset was put to use in the face of autism and education policy, taking the European Union as a research laboratory, and ultimately laying a foundation for a chapter of this thesis. Following the placement, I was invited to collaborate on a second publication in the field of autism and education policy. It was at this point that I also decided to want to pursue academia. After some consultation with both Dr Andres Roman-Urrestarazu and Dr Katarzyna Czabanowska, we agreed that I would take on the autism policy mapping project as my $\mathrm{PhD}$ and play a key role in developing EDUCAUS.

I would like to thank Dr Andres Roman-Urrestarazu and Dr Katarzyna Czabanowska for their wonderful guidance during this process. I also want to thank Sebastian Walsh, Paula Steinhoff, and Wiki Dijkstra for their collaborations on the respective papers. I want to thank all (country) experts who helped verify the interpretations of the policy translations and the completeness of the data. Finally, I want to thank Ines Siepmann for her input and feedback when drafting the final part of this thesis.

Outside the work floor, I would like to thank my friends and family for their continued support during the writing process_-particularly Marc Nijsten and Teun van Dam for providing their perspectives as fellow academics from different fields and Dewi Hombergen for her unconditional assistance in the creation of all the images for this thesis. Finally, I would like to thank my parents especially for their unyielding support and assistance on all aspects.

I hope you enjoy reading this work.

Robin van Kessel

Maastricht, 22 November 2020 


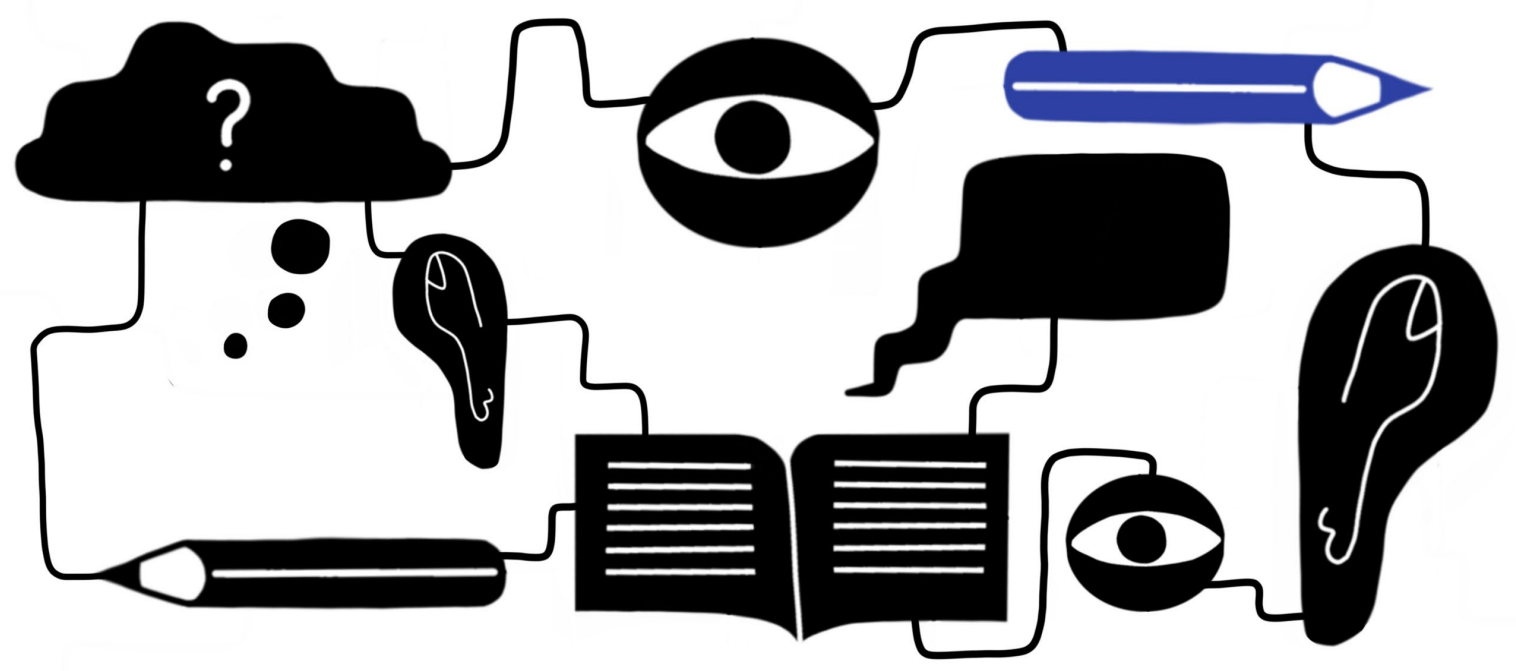

\section{Chapter Zero}

Introduction, Background, and Research Objectives 
Over the last two decades, inclusive education has become a focal point in international policy [1]. Documents such as the United Nations' Salamanca Statement and Convention on the Rights of Persons with Disabilities have stressed that education systems should be developed towards including all children into a single educational environment that addresses the special education needs (SEN) of children in-classroom [2,3]. One particular group of children that often has SEN - and thus could benefit from a system of inclusive education-is the group of autistic children $[4,5]$.

Autism is associated with adverse educational and employment outcomes and many have significant health needs [6-8] and has been a focal point within the European Union (EU) since the early days of its inception. The Charter for Persons with Autism [9], adopted as a Written Declaration by the European Parliament in 1996, set out several rights for people on the spectrum, such as the rights to accessible and appropriate education and to the equipment, assistance and support services necessary to live a fully productive life with dignity and independence. Unfortunately, little specific action followed this Declaration. Two decades later, in 2015, the European Parliament published the Written Declaration on Autism [10]. In the fifth point, it states that "a European strategy should aim at encouraging research on autism, prevalence studies and exchange of best practices regarding evidence-based interventions for autistic children, as well as support and habilitation services for adults." As of yet, most initiatives have focused on establishing a better understanding of autism (e.g. the Autism Spectrum Disorders in the European Union [ASDEU] project and the European Autism Interventions - A Multicentre Study for Developing New Medications [EU-AIMS]) or progressing the rights of people with autism (e.g. work done by Autism-Europe).

Specifically looking at education, one of the responses to the fifth point of the Written Declaration was the creation of the European Consortium for Autism Researchers in Education (EDUCAUS) [11]. The focus of EDUCAUS was to establish an EU-wide autism network that uncovered and shared good practices to improve the environment for people with autism in both education and employment. This thesis contributes to one EDUCAUS objective, namely the analysis and description of education policy in the EU covering 20 out of 28 Member States in order to identify areas of improvement in inclusion policy for autistic children. The key findings allow for the identification of essential drivers that can affect the development of inclusion policy in the EU and specify the directions of future policy and research endeavours for education policy pertaining to autism and inclusion. 


\section{Core Concepts}

This thesis includes an array of abstract concepts with extensive definition(s) that need prior explanation, namely autism, special education needs, inclusive education, and the right to education. In this section, these concepts are explained individually. Additionally, where applicable, it is explained how a concept will be used and/or interpreted in the rest of the thesis.

\section{Autism}

Autism — clinically referred to as Autism Spectrum Conditions — refers to a set of neurodevelopmental conditions characterised by difficulties in communication, social interaction, and unusually narrow interests and/or repetitive behavioural patterns, starting in early childhood and continuing throughout life $[12,13]$. Autism is further associated with adverse educational and employment outcomes, with many having significant health needs [6-8]. More specifically, mental health problems (e.g. anxiety and depression) [14,15], and other health conditions (e.g. epilepsy, gastrointestinal problems and immune dysregulation) are common comorbidities in autism $[8,16]$, making it a significant public health challenge [17].

Furthermore, autism has considerable impact on families and carer due to the diagnosis still carrying considerable stigma across Europe [18-21]. Serious economic challenges often occur in families with a member with autism [18]. In addition to the financial aspects, the support of a family member with autism impacts the daily lives of their families in several ways, such as in their relationships outside the family, higher levels of distress and family obligation, or their employment situation [16,22-24]. Besides various health care challenges, many people with autism remain lifelong dependent on their parents or carers, particularly in terms of their living and occupational situation $[24,25]$.

The global prevalence of autism is estimated to be one percent of the population based on a review of prevalence studies across the world [8] with a male-to-female ratio between 3:1 and 4:1 [8,26]. Additionally, data from the World Health Organisation states that one in 160 children has autism [27]. Over the last decades, autism diagnoses increased steadily. This increase has predominantly been linked to new screening and assessment tools (e.g. moving from the DSM-IV to DSM-5) but also to a greater awareness in the general population [28]. 
Early identification of autism and subsequent personalised help if needed in early life have been shown to benefit autistic people by improving language development, as well as behavioural and cognitive skills [29]. A key part of these therapies lies with the approach taken towards the child's educational and developmental needs, especially considering children in general spend a large amount of time in schools and education, historically, has been as one of the key intervention options for people with autism [4,30]. However, the characteristics of autism are best represented in a dimensional approach [31,32], meaning there is no natural classification on whether a person has a mild, moderate, or severe form of autism. Instead, classification systems (e.g. the Diagnostic and Statistical Manual of Mental Disorders and International Statistical Classification of Diseases and Related Health Problems) are relied upon to make distinctions between severities of autism [12,13]. As such, the corresponding educational needs can differ significantly across persons, location, and time.

\section{Special Education Needs}

The term SEN has no universal definition, but it generally refers to children with "various (combinations of) impairments and/or difficulties in participating in education" [33]. Another interpretation of SEN is "students who need considerably more care and attention than the other students in the class" [34]. The umbrella term of SEN has reportedly been commonly used in the UK for nearly 30 years to address "all children who have developmental difficulties that affect: their learning; their behavioural, emotional, and social development; their communication, and their ability to care for themselves and gain independence" [35]. Further variability across SEN definitions is highlighted by Banks and McCoy [36], where a comparison of the definitions in France, Germany, Greece, Spain, Turkey, Finland, Italy, and the United Kingdom shows that all countries factor disability as part of their SEN definition and either learning difficulty or disadvantage - rarely both. However, a factor that is rarely reflected in the definition of SEN is the needs of students that are particularly gifted - only being found in the Spanish and Turkish definitions [36].

The ambiguity among SEN definitions is reflected in the prevalence rates, which vary heavily across the EU [36] — ranging from estimates of 0.9-1.5\% in the Southern-European countries to $15-17.8 \%$ in Scandinavia. Aside from the ambiguity in definition, the variance is also partially attributable to the inconsistency with which SEN are classified. On average, countries differentiate between six and ten SEN categories, including students who are deaf 
or partially hearing; who are blind or partially sighted; with physical disabilities; with emotional and behavioural difficulties; with speech and language problems; who are in hospital; with moderate or severe learning problems; with a combination of disabilities; and with specific learning difficulties [37]. An alternative to the classification-based system is a resource-based system, which generally refers to the process of a diagnosis being omitted and focus being laid on the needs of the child and services that should be provided [37].

The evidence base of SEN support has been reported previously [4]. It was identified that support in the areas of cognition and learning, social, emotional and mental health, and communication and interaction can lead to significant benefits for the development of children with SEN, while also acknowledging that the SEN for autistic children may differ significantly per person. Examples of SEN as defined by Carrol and colleagues [4] include, but are not limited to linguistic difficulties, problems in communication, or learning disabilities that require additional support provision.

Family support and engagement in both policymaking and education play a key role in supporting children with SEN and improving health outcomes [39]. For example, Northern Ireland was the first country to explicitly stress the importance of education and policy engagement of family members in their Autism Strategy (2013-2020). The Autism Strategy was aimed at involving parents in the education process of their child with autism [40]. In the National Plan for Autism in Children in the UK, active family involvement was one of the core policy principles in taking care of an child with autism [41]. It specifies that families and carers, in the form of parent-professional partnerships, are involved in the accomplishment of development goals set for the child with autism. The extent to which other Member States in the EU have implemented family involvement in their autism policy in SEN is currently unknown, although previous work by Roleska and Roman-Urrestarazu and colleagues has investigated EU SEN policy overall [42].

\section{Inclusive Education}

Inclusive education has widely emerged as a key topic as a result of international developments [1,3]. It incorporates ideas on how education should be organised and can thus be regarded as an educational philosophy [43]. Even though the philosophy of inclusive education is widely accepted, the concept itself remains ambiguous [44] — having several different definitions that range from "inclusion as concerned with disability and SEN" to 
"inclusion as a principled approach to education and society." Other portrayals of inclusion consist of "a matter of placement by substituting the former term 'integration' for inclusion" [45], which emphasises established procedures to meet the needs of children with SEN mainstream education [46]; enhancement of human diversity and actions against discrimination and exclusion - often at the international level [47]; the framework of inclusion being a process, which "entails that inclusion has to be seen as a never-ending search to find better ways of responding to student diversity. It is about learning how to live with difference and learning how to learn from difference" [47]; and that inclusion relates to the identification and removal of barriers, such as school organisation, teaching methodology, and progress evaluation [47].

Much like its definition, the conceptualization of inclusion also varies. Ainscow, Booth, and Dyson [44] summarised inclusive education in six core categories: (1) inclusion as concerned with disability and SEN, (2) inclusion as a response to disciplinary exclusions, (3) inclusion as about all groups vulnerable to exclusion, (4) inclusion as the promotion of the school for all, (5) inclusion as 'Education for All', and (6) inclusion as a principled approach to education and society. While the categories themselves show a certain overlap, they do encapsulate the perspectives from which inclusion is most commonly addressed [48]. Additionally, a report by the United Nations Educational, Scientific, and Cultural Organization (UNESCO) [49] explained that the concept of inclusive education has evolved towards "the idea that all children and young people, despite different cultural, social and learning backgrounds, should have equivalent learning opportunities in all kinds of schools." In this context, an inclusive setting is defined by “(a) respecting, understanding and taking care of cultural, social and individual diversity; (b) the provision of equal access to quality education; and (c) close co-ordination with other social policies." Ultimately, all definitions and concepts share a common element with regards to inclusive education, namely that a child with SEN has to have access to all the necessary support and services he or she needs to fully participate in mainstream education [50].

A review by van Mieghem and colleagues [43] found that five themes were investigated most commonly in regards to inclusive education: (1) attitudes towards inclusive education, (2) teachers' professional development in inclusive education, (3) inclusive education practices, (4) student participation, and (5) critical reflections on inclusive education research —of which the first four are relevant to the actual implementation of inclusion. Firstly, attitudes 
towards inclusive education was measured separately between teachers, parents, and typically developing students. It was found that, on average, the attitudes of teachers towards inclusive education are fairly negative, conversely to the attitudes of parents and peers. Teachers, however, play a fundamental part in the implementation of inclusive education, so it is paramount to positively affect their attitudes. Positive attitudes of teachers, parents and typically developing students are related to their knowledge of SEN and their experience with inclusive education. An interesting finding in this part was that there is a generally less positive attitude towards children with cognitive impairment and severe behavioural conditions compared to children with sensory impairment and physical conditions. Secondly, professional development of teachers, was found to be more effective if it focusses on specific SEN or disabilities, rather than inclusive education in general. Training programmes for teachers that focus on specific concerns of teachers and their teaching context are the most beneficial in supporting change in teachers' practice.

Thirdly, supplementary support for teachers and support from peers for children with SEN were found to be practices that enhance inclusive education and can be provided by other teachers in the form of co-teaching or by teaching assistants. This additional support is to help teachers create more opportunities to directly instruct children with SEN and specifically focus on their development goals. Peer support practices — such as peer tutoring and cooperative learning - were found to increase the social competence of children with emotional and behavioural conditions and strengthen the reading comprehension and phonological skills of children with reading and/or moderate learning disabilities. Finally, student participation focused on the academic and social participation of children with SEN within mainstream schools. Social participation, in this context, involved the presence of mutual positive social contact or interaction, acceptance and friendships between typical children and their peers with SEN. Mixed classes consistent of a larger number of typically developing peers and a minority of children with SEN were found to foster positive relationships. Results on academic performance of typical children were too scarce in this review to make an informed statement on the effect of inclusion. Academic performance of children with SEN, on the other hand, was found to flourish in inclusive education.

Experiences and learning outcomes for typical children in inclusive education were focused on by Dell'Anna, Pelligrini, and Ianes [51]. In terms of experiences, they found that peer attitudes and beliefs are affected both by the type of school and individual factors, such as gender. Attending inclusive education could have a positive impact, 
while the placement of a special education department in a school could have a negatively one. Peers who have or at one point had direct experience with people with disabilities were found to be more cognizant of the impact of a disability on the social and emotional wellbeing of the person and had a better understanding of their real abilities. Contradicting results were found with regards to the impact of age on the attitudes towards SEN. Some reviewed studies indicated that older children had more positive attitudes towards their peers with SEN, while other studies concluded the opposite. The nature of SEN was also found to be a matter that impacts attitude towards SEN. A positive correlation was found between the severity of a condition and peer attitude. Furthermore, behavioural intentions and attitudes were found to be more positive towards physical conditions than their mental counterparts. Concerns raised by typical children involve the probability that the behaviour and difficulties of children with SEN could affect their own learning and achievement, fears that lessen if they take the support offered to children with SEN into consideration. In terms of learning outcomes, little literature was about peers in inclusive settings, and most of the studies used qualitative methods. Since a few experimental studies on the effects of inclusion in a controlled setting were selected, a causal relationship between the use of inclusive practices and peer attitudes and achievement could not be inferred. Even though the learning outcomes could not be mapped by this review, some interesting findings were still reported, namely the previously mentioned lack of a common definition of inclusion (most studies included in the review used a narrow and ambiguous view of the concept of school inclusion, mostly associated with the presence of children with SEN) and the lack of agreement on the meaning of quality of inclusion and which criteria define it.

There are complications with regards to the implementation of inclusive systems. Education systems typically develop in very specific contexts, both in policy and practice, making them highly individual [52], thus - by extension - making it difficult to provide general guidelines that are applicable to various education systems. Systems of inclusion are also typically embedded in a combination of mainstream and special education frameworks [52]. While international guidelines tend to be translated into country-specific settings, it is the establishment of an explicit definition of inclusion that usually benefits this process [47], which can be troubling given its ambiguity. Furthermore, teachers - who play a key role as they have to realise implemented inclusion policies-generally support the concept of inclusion from a policy standpoint $[53,54]$. However, from a practical point of view there is much concern about the implementation of it $[55,56]$. There are still widespread negative 
attitudes towards the inclusion of children with SEN among many mainstream schools teachers [57]. Moreover, in several studies investigating the attitude of teachers towards inclusive education, it became apparent that, on average, teachers have greater aversions towards children with learning, behavioural and emotional difficulties [54,57-60]. Additional factors which were found to improve the attitude towards inclusion are higher expertise and improved training teachers received and the availability of support facilities $[61,62]$.

\section{Right to Education}

An universal framework for human rights started being developed after the introduction of the Universal Declaration of Human Rights by the UN [63] in which it is outlined that the rights set out in this document are "not a reward for good behaviour. They are not countryspecific, or particular to a certain era or social group. They are the inalienable entitlements of all people, at all times, and in all places - [...], whether or not they are disabled." It then proceeds to establish a framework of the fundamental rights of people, including but not limited to a prohibition on discrimination on any ground, the right to life and liberty, a prohibition to degrading treatment, equality before the law for all people, the right to employment without discrimination, and the right to education without discrimination. Roleska and Roman-Urrestarazu also identified other UN documents that added to this framework, such as the Declaration on the Rights of Disabled Persons, and the CRPD [3,64]. The former stresses the right of people with intellectual, developmental and learning conditions specifically to receive appropriate education in order to develop themselves to their maximum potential, while the latter emphasises that children with disabilities should be able to fully enjoy all human rights and fundamental freedoms on an equal basis with other children and expresses the need for inclusive education to be developed.

Several studies have investigated the tension between big and small European Union (EU) Member States in their approach towards European involvement in aspects of policy traditionally left to Member States including health and education [65-68]. In two analyses of health systems reforms in small EU Member States, it is explained how, when contemplating a reform, "small states determine what is feasible to be accomplished at national level versus relying on technical capacity and resources found in larger countries" [65] and how "small states benefit disproportionately from the existence of effective regional organisations and 'soft' security aspects, including public health, have been described amongst such benefits" 
[66]. Thorhallsson and Wivel [67] explain that the power dynamic between big and small states has shifted due to the introduction of regulations that apply to interstate relations in the EU. As a result, under these regulations, big and small EU Member States are considered sovereign and equal before the law. Consequently, big EU Member States can no longer dictate international law without the interference of their smaller counterparts. Ultimately, this led to the creation of a dilemma for small EU Member States: Do they focus on preserving their national autonomy or do they attempt to influence EU affairs through participation and European integration and thus achieve a sense of stability at the potential cost of their national autonomy? Haugevik and Rieker [68] explain that, while the decision between autonomy and integration is an important one for all EU Member States, it may be comparatively more important for the smaller ones. They also note that small EU Member States, when compared to their larger neighbours, almost always be more limited in the policy options available to them.

Additionally, various EU Member States (e.g. Latvia, Lithuania, Estonia, Eastern Germany, Czech Republic, Slovakia) have been under influence of the former Soviet Union for distinct periods of time. In order for the former Soviet-influenced countries to join the UN and EU, they had to adopt a new ideology — moving from a Soviet-based approach to a UN human rights-based approach. In short, both forms of tensions are critical in the development of education for autistic children, yet have not been investigated to date.

The investigation of the right to education for autistic children was pioneered by Roleska and Roman-Urrestarazu and colleagues [42]. In their work, which analysed the United Kingdom, France, Spain, and Poland, they recognised that people with autism should be given opportunities to develop their full potential, preferably within a mainstream/inclusive school setting. They also showed all four countries under study have been influenced extensively by $\mathrm{UN}$ and EU policies over the years and that the right and various levels of access to education for autistic children have been established as a result of this international influence. However, they also acknowledge their results cannot be generalised as their review only included four countries. Therefore, the goal of this thesis is to build upon this work and provide evidencebased guidelines on how the policy environment for autistic children can be improved. 


\section{Goals and Objectives}

The main objective of this thesis is in line with one of the core objectives of EDUCAUS, namely the analysis of (special) education policy and human rights policy to determine how the right and access to education for autistic children in the EU can best be improved-with a particular focus on inclusive education. This main objective is operationalized by the following themes: (1) Right to Education; (2) Access to Education; (3) Support; (4) Tension; and (5) Trends. It has to be noted that EDUCAUS includes two additional dimensions, namely the impact of Europeanization and austerity on the development of education. While these factors are definitely important to consider, they do not fall under the scope of inclusive education directly and are therefore not part of this thesis.

Each of these themes has one or more specific objectives that it incorporates. Right to Education assess the influence of international guidelines on national policy, building upon the work of Roleska and Roman-Urrestarazu [42]. Note that throughout this thesis, the terms "international policy" and "international guidelines" refer to the policies drafted by the UN and its constituent bodies (e.g. UNESCO, UNICEF, etc.). Access to Education determines how national policies contribute to an environment in which a child with autism can follow education needs to be continued, also building upon the work of Roleska and RomanUrrestarazu [42]. Support has two specific focal points: it determines the extent to which Member States in the EU have implemented family involvement in their autism and (special) education policy, and it investigates how teachers are facilitated and/or enabled to develop themselves in the face of inclusive education on a policy level and how this reflects back on autistic children in the EU. Tension also explores two distinct topics: it examines how small states fare in the implementation of international guidance on the topic of education and it investigates the effects of the former Soviet Union on how education systems of countries that were under its influence were shaped. Finally, Trends discerns what factors either aid or obstruct the development of inclusive education for autistic children on a policy level within the EU. In Chapter Seven, these themes will be used again to discuss the findings of the paper.

One piece of terminology that needs to be considered is the use of drafted, implemented, ratified, and adopted throughout the chapters of this thesis. The scope of this thesis is strictly written policy-based. As such, when using these terms, it refers to the fact that the policy in question has been entered into the law, rather than implemented in practice. 


\section{Core Theoretical Models}

\section{United Nations Convention on the Rights of Persons with Disabilities}

A decade after the ratification of the Convention on the Rights of Persons with Disabilities (CRPD), the United Nations Committee on Rights of Persons with Disabilities published, in the fourth General Comment [69], four overarching educational approaches that schools can adopt (Figure 1): a) exclusion, which indicates an environment where children are denied access to education in any way; b) segregation, which happens when children with SEN are being educated in a separated environment; c) integration, which describes the environment where children with SEN are included in mainstream education, yet have to completely adapt to its standardised requirements; and d) inclusion (also known as inclusive education), which entails going beyond simply integrating children with SEN into mainstream education, to a process of systemic educational reform with a vision of providing equitable learning experiences for all children. They find that inclusive education conveys "clear and consistent evidence [of] substantial short- and long-term benefits for children with and without disabilities" [30]. When looking at the children with disabilities specifically, they reported improved social and cognitive development, along with better integration into post-secondary education or employment.

This model was used in an earlier synthesis of evidence on inclusive education [30], in which it functioned as a guideline to assess the educational environments for children with Down syndrome specifically. This model in particular was chosen for its close connection to the UN human rights foundation, on which the policy efforts of EDUCAUS - and thus this thesiswere based. In this thesis, it is used similarly to how it was used by Hehir and colleagues [30], namely as a means of comparison and analysis. Based on the contents of the policies that are identified in Chapters One through Five, we can identify to what extent inclusion-as defined by the United Nations [69] - is in place in the countries under study. Subsequently, the four educational approaches are used in Chapter Six as an outcome measure for the identification of trends that are associated with inclusive education. Finally, in Chapter Seven, it is determined if the findings of this research are in line with the model and whether the model needs adjustments in case the explanation as a result of the model is incomplete. 


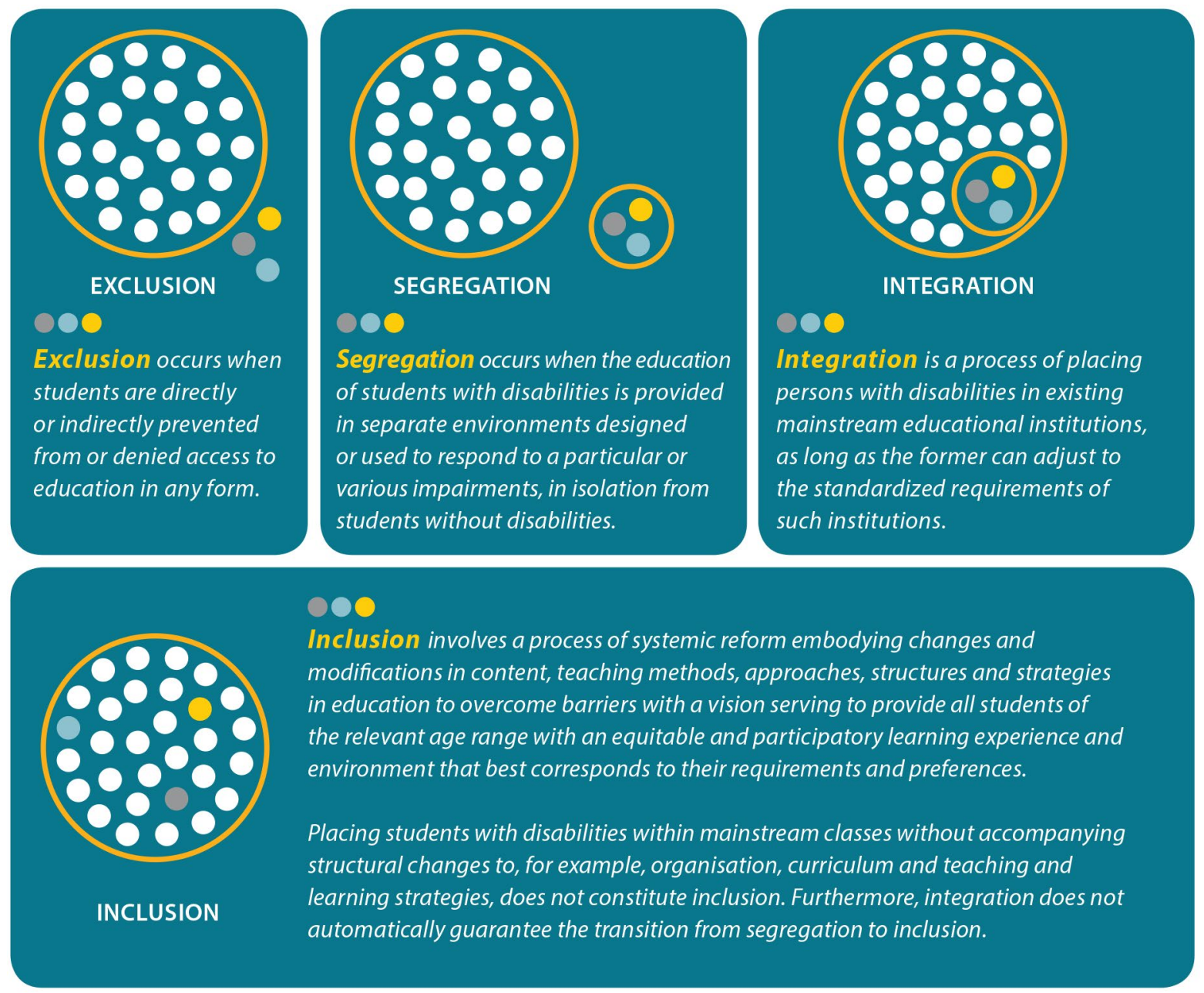

Figure 1. An illustration of the four steps of inclusion that a school can take. Source: United Nations Committee on the Rights of Persons with Disabilities (text) and Hehir and colleagues (visualization) [30,69].

\section{Disability Rights in Education Model}

While the UN Convention on the Rights of Persons with Disabilities clearly explains the different settings that an education system can have, it does not explore the complexities and interrelations between factors that are required to achieve inclusion. For that, the Disability Rights in Education Model (DREM) [70] is a more viable model to use. The DREM explains that three levels of action are interdependent in the development of inclusive education: local/regional, national, and international action.

Policy stands at the center of the national level as a factor that enables inclusion by providing basic conditions needed for inclusion to be effective. It points out that teacher training, childcentered pedagogy, collaborations, sensitization, community involvement, and representation are key for developing inclusion. In this thesis, these elements are all covered under the 
Support section. It also establishes that basic human rights, such as the rights to health and education, need to be met at the international level. These are represented by Right to Education and Access to Education. Finally, the DREM establishes that context is a crucial factor at every level. Countries in the EU have developed differently over time or at different speeds (i.e. some were heavily influenced due to Soviet occupation, others may have prioritized their policy developments differently as a result of having a smaller population size and, by extension, less children with SEN). These elements are represented in this thesis under the Tension section.

\section{Methodologies}

The methodologies in this thesis aim at exploring the written policies in the countries under study. In doing so, the path dependence analyses focus on determining the chronological development of (special) education policy in the countries under study. These chronological developments are narratively compared in the respective chapters. The qualitative comparative analysis then aims to make a more systematic analysis of policy environments in order to determine key elements that can (further) facilitate the development of inclusion. Please note that the use of these methodologies is fully focused on the written policy environments and cannot make statements regarding the practical situations in the countries under study. Further details of the specific methodologies are explained below.

\section{Path Dependence Analysis}

In Chapters One through Five, the same methodology is used every time in order to guarantee that data is acquired that is comparable for analysis. This methodology consists of three parts every time: a scoping review for data acquisition, a path dependence analysis, and a collaboration with country experts. Firstly, a scoping review was used as it is particularly useful for swift mapping of key concepts that underpin a wide research area and is especially suitable for investigating complex matters that have not been comprehensively reviewed $[71,72]$. Secondly, the path dependence analysis is performed. Thirdly, to account for possible translation errors and/or interpretation bias, country experts were involved in determining the completeness and correctness of the dataset and its interpretation.

The analysis of policy path interdependency draws on past and current UN, EU, and national policies in the field of SEN and autism from 1948 up to date. Path dependence approaches allow the identification of policymaking patterns and establish influences and interrelations 
among policies in linear layers of temporality [73]. It also enables policy process-tracing, which (1) aims to explain what factors are present in critical policy junctures, (2) aims to create a reference framework and depict how decision processes come to conclusions, and (3) aims to describe how behaviour that takes place in different stakeholders as a response to external factors (e.g. a change in the policy environment) affects different institutional arrangements [74,75]. In these cases, the Universal Declaration of Human Rights [63] is taken as the starting point, a milestone document that influenced the creation and the content of EU and national policies. We used a timeline to show connection and overlap between policies to enable further analysis. This enabled the interpretation of policy creation as historical sequences and patterns and allowed for the identification of path dependence [73]. Current disability, inclusion, and autism policies are a result of previous events that were tracked with the use of this framework. All policies were analysed by identifying their input in the field of education, advantages and disadvantages, and their relation to other policies.

This comparative policy analysis based on the scoping reviews and path dependence analyses leads to obtaining the results that can be considered individual case studies on the development of access to (inclusive) education for autistic children, each EU Member State forming its own case. One particular challenge of comparative studies on inclusion is to capture the complexity of the terminology and show different possible pathways and interpretations and discuss their respective consequences for practice [52]. The dataset that the reviews output consists of a medium number of cases, which enables the use of systematic comparison and intensified case-based methodologies, such as a Qualitative Comparative Analysis (QCA) [76-78] in order to identify patterns in data that can potentially point towards factors that positively or negatively influence the development of inclusive education.

\section{Qualitative Comparative Analysis}

Chapter Six involves the synthesis of the policy data of Chapters One through Five by means of a qualitative comparative analysis (QCA). QCA is a mixed-method approach developed by Ragin [78] and used to explore and analyze quantitative and qualitative data from a medium number of case studies by using set theory and Boolean minimization to identify patterns in data $[77,78]$. Set theory refers to either a branch of mathematics or a branch of symbolic logic that handles the nature and relations of sets. It allows for QCA to take an alternative approach to causality compared to probabilistic methods (such as regression models) [79]. QCA 
instead considers what variables (henceforth conditions) — individual or combined — are required to produce an outcome $[79,80]$. Boolean minimization can be summarized as follows: "if two Boolean expressions differ in only one causal condition yet produce the same outcome, then the causal condition that distinguishes the two expressions can be considered irrelevant and can be removed to create a simpler, combined expression" $[78,80]$.

QCA typically uses case studies in which cause and effect are determined and explained. The conditions are classified as either necessary or sufficient [81]. Necessary conditions are essential for consistently producing an outcome, though require other (sufficient) conditions to be present. Sufficient conditions, on the other hand, can individually produce an outcome, though inconsistently [81].

The comparative importance of conditions can be evaluated either by (1) their identification as necessary conditions with higher consistency scores pointing to a stronger relationship with the outcome, or (2) the presence of conditions in multiple causal pathway of sufficient causes [82]. Additionally, QCA incorporates two approaches to causation: conjunctural causation and equifinal causation. Conjunctural causation recognizes that the conditions that produce an outcome do not work isolated but complementary, while equifinal causation acknowledges the possibility of more than one set of conditions to produce an outcome [82].

\section{Outline of the thesis}

The abovementioned objectives will be discussed through the inclusion of the six scientific papers that were written in preparation for this thesis, respectively Chapters One through Six. The entire structure of this thesis can be depicted in a single model, in which the right and the access to education form the roof and the individual factors that are discussed in Chapters One through Five form the pillars, which is all based on the foundation of the international documents that determine human rights, such as the Universal Declaration of Human Rights and the Convention on Rights of Persons with Disabilities [3,63]. This image is shown in Figure 2. 


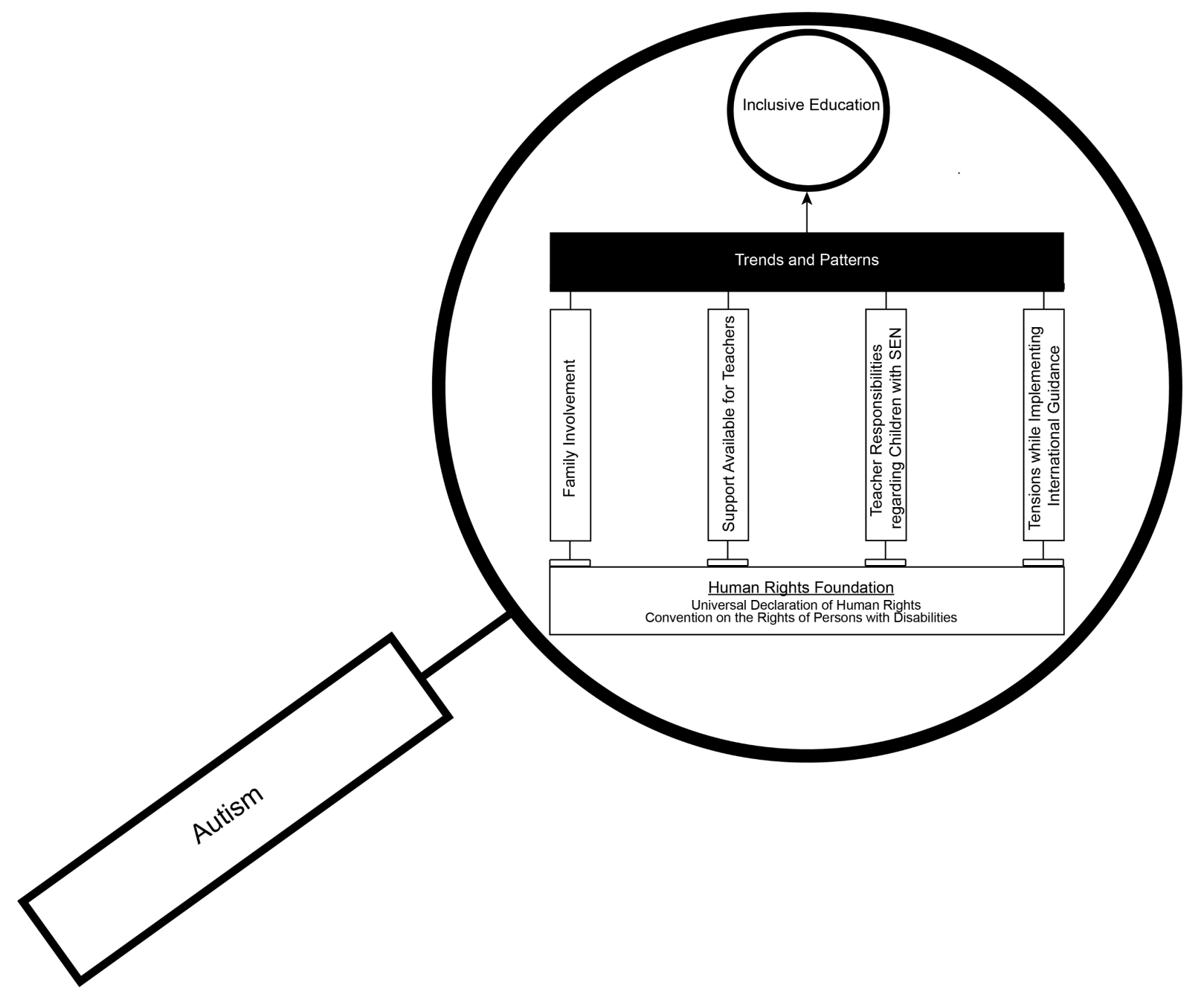

Figure 2. A visual representation of the structure of this thesis, explaining what elements of inclusion are investigated through the perspective of autism. Source: author's own creation.

\section{Chapter One}

This chapter discusses family involvement in autism and education policy. It is a continuation of the analysis of United Nations (UN) and EU policy and expands the Member State coverage by investigating the Netherlands, Germany, and Belgium on their education policy. It showcases how families are involved in the education of autistic children on a policy level, differences between unified and federal states, as well as how the size of a legislative region can impact the approach it takes towards (special) education policy.

\section{Chapter Two}

This chapter investigates how inclusion is integrated into the national policy environment of Denmark, Sweden, and Finland. It elaborates how international guidance was involved in the 
development of the education system, as well as how teachers are trained to work with children with SEN.

\section{Chapter Three}

This chapter examines the responsibilities that teachers are given on a policy level with regards to children with SEN. In particular, it investigates the policy environments of Austria, Hungary, Slovakia, and the Czech Republic. This paper also explores the effect that different supranational influences have had on the shaping on the respective education system (e.g. the Soviet regime, the division of Czechoslovakia into two independent states, and the accession to the EU).

\section{Chapter Four}

This chapter explores possible tensions between large and small EU Member States in adhering to international guidance. This paper does so by analysing the policy environments of Malta, Cyprus, Luxembourg, and Slovenia. By comparing their policy approaches to the approaches already found in larger Member States, it is determined whether tension exists or not.

\section{Chapter Five}

This chapter specifically reports on the influence that the former USSR had in shaping national education systems in the Baltic States: Estonia, Latvia, and Lithuania. Since these countries remained a part of the former Soviet Union until its collapse, they were deemed best suitable to determine the impact that the Soviet Regime had on the development of the education system for children with SEN.

\section{Chapter Six}

This chapter synthesizes the findings of all previous chapter, combined with the findings of Roleska and Roman-Urrestarazu and colleagues [42]. Due to the fact that all previous chapters involve their separate selection of countries (essentially cases), a comparative methodology is used that allows the analysis of qualitative data in a quantitative fashion: a qualitative comparative analysis [78,83]. 


\section{Chapter Seven}

This final chapter discusses the findings of all previous chapters in the form of a General Discussion. As such, it consists of the findings of the twenty Member States that are included in this thesis - sixteen Member States covered by the previously discussed Chapters and four covered by the work mentioned in the Preface [42]. The reason this additional work is also referred to, is because it represents a significant portion of the EU population that is affected by its policy. As such, the conclusions drawn by this thesis will only be fortified by also considering the findings of this article. Subsequently, an interpretation of these findings is made in light of empirical data that focuses on the practical situation, limitations are acknowledged, and future policy scenarios for the improvement of access to education and inclusive education for children on the autism spectrum are explored.

It is important to note that the right to education is an element that is not discussed in a single chapter specifically. Instead, it is covered by Chapters One through Five. This is because the papers corresponding to these chapters all have the same overarching goal: to determine how the right to education for autistic children is regulated in the EU and its constituent Member States. 


\section{References}

1. UNESCO. Inclusion in Education: The Participation of Disabled Learners. Dakar; 2000. Available from: https://unesdoc.unesco.org/ark:/48223/pf0000123486

2. UNESCO. The Salamanca Statement and Framework for Action on Special Needs Education. 1994 [cited 2018 May 19]. Available from: http://www.unesco.org/education/pdf/SALAMA_E.PDF

3. United Nations. Convention on the Rights of Persons with Disabilities. 2006. Available from: http://www.ohchr.org/EN/HRBodies/CRPD/Pages/ConventionRightsPersonsWithDisa bilities.aspx\#3

4. Carroll J, Bradley L, Crawford H, Hannant P, Johnson H, Thompson A. SEN support: A rapid evidence assessment. 2017. Available from:

https://assets.publishing.service.gov.uk/government/uploads/system/uploads/attachme nt_data/file/628630/DfE_SEN_Support_REA_Report.pdf

5. Baron-Cohen S. Editorial Perspective: Neurodiversity - a revolutionary concept for autism and psychiatry. J Child Psychol Psychiatry Allied Discip. 2017;58(6):744-7.

6. Ganz M. The lifetime distribution of the incremental societal costs of autism. Arch Pediatr Adolesc Med. 2007 Apr 1;161(4):343-9. Available from:

http://dx.doi.org/10.1001/archpedi.161.4.343

7. Shattuck PT, Narendorf SC, Cooper B, Sterzing PR, Wagner M, Taylor JL. Postsecondary Education and Employment Among Youth With an Autism Spectrum Disorder. Pediatrics. 2012 May 14; Available from: http://pediatrics.aappublications.org/content/early/2012/05/09/peds.2011-2864.abstract

8. Lai M-C, Lombardo M V, Baron-Cohen S. Autism. Lancet. 2013/10/01. 2014;383(9920):896-910. Available from: https://www.sciencedirect.com/science/article/pii/S0140673613615391?via\%3Dihub

9. Autism-Europe. Charter for Persons with Autism. 1992. Available from: http:/www.autismeurope.org/wp-content/uploads/2017/08/charter-for-persons-withautism-1.pdf

10. European Parliament. Written Declaration on Autism. 2015 [cited 2018 May 3]. Available from: http://www.autismeurope.org/wp-content/uploads/2017/08/writtendeclaration-on-autism-to-the-ep.pdf

11. EDUCAUS. European Consortium for Autism Researchers in Education. 2019 [cited 2019 Jun 19]. Available from: https://www.educaus.eu/ 
12. American Psychiatric Association. Diagnostic and statistical manual of mental disorders (5th ed.). Washington, DC; 2013.

13. World Health Organisation. International Statistical Classification of Diseases and Related Health Problems 10th Revision. 2016 [cited 2018 Nov 15]. Available from: http://apps.who.int/classifications/icd10/browse/2016/en\#/F84.5

14. Croen LA, Zerbo O, Qian Y, Massolo ML, Rich S, Sidney S, et al. The health status of adults on the autism spectrum. Autism. 2015 Oct;19(7):814-23.

15. Simonoff E, Pickles A, Charman T, Chandler S, Loucas T, Baird G. Psychiatric Disorders in Children With Autism Spectrum Disorders: Prevalence, Comorbidity, and Associated Factors in a Population-Derived Sample. J Am Acad Child Adolesc Psychiatry. 2008 Aug;47(8):921-9.

16. Gurney JG, Mcpheeters ML, Davis M. Parental Report of Health Conditions and Health Care Use Among Children With and Without Autism Article in Archives of Pediatrics and Adolescent Medicine $\cdot$ Child Care Center Illness Policies View project Outcomes and Survivorship in Childhood Cancer View . 2006;

17. Newschaffer CJ, Curran LK. Autism: An Emerging Public Health Problem. Vol. 118, Public Health Reports. 2003.

18. Knapp M, Romeo R, Beecham J. Economic cost of autism in the UK. Autism. 2009;13(3):317-36. Available from: http://journals.sagepub.com/doi/pdf/10.1177/1362361309104246

19. Howlin P, Goode S, Hutton J, Rutter M. Adult outcome for children with autism. J Child Psychol Psychiatry. 2004;45(2):212-29. Available from: http://onlinelibrary.wiley.com/doi/10.1111/j.1469-7610.2004.00215.x/abstract

20. van Heijst BFC, Geurts HM. Quality of life in autism across the lifespan: A metaanalysis. Autism. 2015;19(2):158-67. Available from: http://journals.sagepub.com/doi/pdf/10.1177/1362361313517053

21. World Health Organisation. Autism spectrum disorders. 2017 [cited 2018 Apr 25]. Available from: http://www.who.int/mediacentre/factsheets/autism-spectrumdisorders/en/

22. Eskow K, Pineles L, Summers JA. Exploring the Effect of Autism Waiver Services on Family Outcomesj ppi_284 28..35. 2011.

23. Gau SS-F, Chou M-C, Chiang H-L, Lee J-C, Wong C-C, Chou W-J, et al. Parental adjustment, marital relationship, and family function in families of children with autism. Res Autism Spectr Disord. 2012 Jan;6(1):263-70. 
24. Lee L-C, Harrington RA, Louie BB, Newschaffer CJ. Children with Autism: Quality of Life and Parental Concerns. J Autism Dev Disord. 2008 Jul;38(6):1147-60.

25. Billstedt E, Gillberg C, Gillberg C. Aspects of quality of life in adults diagnosed with autism in childhood: A population-based study. Autism. 2011;15(1):7-20.

26. Loomes R, Hull L, Mandy WPL. What Is the Male-to-Female Ratio in Autism Spectrum Disorder? A Systematic Review and Meta-Analysis. J Am Acad Child Adolesc Psychiatry. 2017 Jun 1 [cited 2018 Aug 23];56(6):466-74. Available from: http://www.ncbi.nlm.nih.gov/pubmed/28545751

27. World Health Organisation. Autism spectrum disorders. 2019 [cited 2020 Feb 14]. Available from: https://www.who.int/en/news-room/fact-sheets/detail/autismspectrum-disorders

28. Cervantes PE, Matson JL, Goldin RL. Diagnosing ASD in Very Early Childhood. In 2016. p. 157-73.

29. Warren Z, McPheeters ML, Sathe N, Foss-Feig JH, Glasser A, Veenstra-VanderWeele J. A Systematic Review of Early Intensive Intervention for Autism Spectrum Disorders. Pediatrics. 2011 May 1 [cited 2018 Aug 23];127(5):e1303-11. Available from: http://www.ncbi.nlm.nih.gov/pubmed/21464190

30. Hehir T, Grindal T, Freeman B, Lamoreau R, Borquaye Y, Burke S. A Summary of the Research Evidence on Inclusive Education. São Paulo: Instituto Alana; 2016. Available from: https://www.abtassociates.com/sites/default/files/201903/A_Summary_of_the_evidence_on_inclusive_education.pdf

31. Allison C, Auyeung B, Baron-Cohen S. Toward Brief "Red Flags" for Autism Screening: The Short Autism Spectrum Quotient and the Short Quantitative Checklist in 1,000 Cases and 3,000 Controls. J Am Acad Child Adolesc Psychiatry. 2012 Feb 1 [cited 2018 Apr 30];51(2):202-212.e7. Available from: https:/www.sciencedirect.com/science/article/pii/S0890856711010331?via\%3Dihub

32. Grzadzinski R, Huerta M, Lord C. DSM-5 and autism spectrum disorders (ASDs): an opportunity for identifying ASD subtypes. Mol Autism. 2013 May 15 [cited 2018 Apr 25];4(1):12. Available from: http://www.ncbi.nlm.nih.gov/pubmed/23675638

33. Pijl SJ, Frostad P, Flem A. The social position of pupils with special needs in regular schools. Scand J Educ Res. 2008;52(4):387-405.

34. Dijk W Van, Verheul I, Klompe M. Zorgleerlingen en de PCL. Een onderzoek naar het functioneren van de PCL en de kenmerken van zorgleerlingen [Special educationial needs and the Permanent Committee for Student Care]. Utrecht; 2003. 
35. Lindsay G. Educational psychology and the effectiveness of inclusive education/mainstreaming. Br J Educ Psychol. 2007;77(1):1-24.

36. Banks J, McCoy S. A Study on the Prevalence of Special Educational Needs. Trim; 2011. Available from:

https://www.researchgate.net/profile/Selina_Mccoy2/publication/258506132_A_Study _on_the_Prevalence_of_Special_Educational_Needs/links/53ed02320cf23733e805325 7/A-Study-on-the-Prevalence-of-Special-Educational-Needs.pdf

37. Meijer C, Soriano V, Watkins A. Special Needs Education in Europe. Middelfart, Brussels; 2003.

38. Department for Education. Special educational needs and disability code of practice: 0 to 25 years. 2015 .

39. The Autism Strategy and Action Plan (2013-20). 2013 [cited 2018 May 13]. Available from: https://www.health-ni.gov.uk/sites/default/files/publications/dhssps/autismstrategy-action-plan-2013_0.pdf

40. NIASA. National Autism Plan for Children (NAPC). The National Autistic Society. 2003.

41. Roleska M, Roman-Urrestarazu A, Griffiths S, Ruigrok AN V., Holt R, van Kessel R, et al. Autism and the right to education in the EU: Policy mapping and scoping review of the United Kingdom, France, Poland and Spain. Jan Y-K, editor. PLoS One. 2018 Aug 30 [cited 2019 Apr 26];13(8):e0202336. Available from: http://dx.plos.org/10.1371/journal.pone.0202336

42. Van Mieghem A, Verschueren K, Petry K, Struyf E. An analysis of research on inclusive education: a systematic search and meta review. Int J Incl Educ. 2018;1-15. Available from: https://doi.org/10.1080/13603116.2018.1482012

43. Ainscow M, Booth T, Dyson A. Improving Schools, Developing Inclusion. Abingdon: Routledge; 2006 [cited 2020 Jan 22]. Available from: https://elib.umkendari.ac.id/eb_el/\%5BAinscow_Dyson_B\%5D_Improving_Schools, Developing_In(BookFi.org).pdf

44. Amor AM, Hagiwara M, Shogren KA, Thompson JR, Verdugo MÁ, Burke KM, et al. International perspectives and trends in research on inclusive education: a systematic review. Int J Incl Educ. 2018;23(12):1277-95. Available from: https://doi.org/10.1080/13603116.2018.1445304

45. Nilholm C, Göransson K. What is meant by inclusion? An analysis of European and North American journal articles with high impact. Eur J Spec Needs Educ. 2017 Jul 3 
[cited 2020 Jan 22];32(3):437-51. Available from:

https://www.tandfonline.com/doi/full/10.1080/08856257.2017.1295638

46. IBE-UNESCO. Training Tools for Curriculum Development - Reaching Out to All Learners: A Resource Pack for Supporting Inclusive Education. Geneva, Switzerland; 2016.

47. Messiou K. Research in the field of inclusive education: time for a rethink? Int J Incl Educ. 2017;21(2):146-59.

48. IBE-UNESCO. International Conference on Education; 48th; Inclusive education: the way of the future, reference document; 2008. Geneva; 2008 [cited 2020 Jan 22]. Available from:

http://www.ibe.unesco.org/fileadmin/user_upload/Policy_Dialogue/48th_ICE/CONFI NTED_48-3_English.pdf

49. Kurth JA, Gross M. The Inclusion Toolbox: Strategies and Techniques for all Teachers. California: Corwin Press; 2014.

50. Dell'Anna S, Pellegrini M, Ianes D. Experiences and learning outcomes of students without special educational needs in inclusive settings: a systematic review. Int J Incl Educ. 2019;1-16. Available from: https://doi.org/10.1080/13603116.2019.1592248

51. D'alessio S, Watkins A. International Comparisons of Inclusive Policy and Practice: are we talking about the same thing? Res Comp Int Educ. 2009 [cited 2020 Jan 24];4. Available from: www.wwwords.co.uk/RCIE

52. Boyle C, Topping K, Jindal-Snape D. Teachers' attitudes towards inclusion in high schools. Teach Teach. 2013 Oct;19(5):527-42.

53. De Boer A, Pijl SJ, Minnaert A. Regular primary schoolteachers' attitudes towards inclusive education: A review of the literature. Int J Incl Educ. 2011;15(3):331-53.

54. Rouse M. Developing Inclusive Practice: A Role for Teachers and Teacher Education? Educ North. 2008;16:6-13.

55. Humphrey N, Symes W. Inclusive education for pupils with autistic spectrum disorders in secondary mainstream schools: Teacher attitudes, experience and knowledge. Int J Incl Educ. 2013;17(1):32-46.

56. MacFarlane K, Woolfson LM. Teacher attitudes and behavior toward the inclusion of children with social, emotional and behavioral difficulties in mainstream schools: An application of the theory of planned behavior. Teach Teach Educ. 2013;29(1):46-52. Available from: http://dx.doi.org/10.1016/j.tate.2012.08.006

57. Avramidis E, Norwich B. Teachers' attitudes towards integration/inclusion: a review 
of the literature. Eur J Spec Needs Educ. 2002;17(2):129-47.

58. Forlin C, Loreman T, Sharma U, Earle C. Demographic differences in changing preservice teachers' attitudes, sentiments and concerns about inclusive education. Int $\mathbf{J}$ Incl Educ. 2009;13(2):195-209.

59. Monsen JJ, Ewing DL, Kwoka M. Teachers' attitudes towards inclusion, perceived adequacy of support and classroom learning environment. Learn Environ Res. 2014 Apr;17(1):113-26.

60. Costello S, Boyle C. Pre-service Secondary Teachers' Attitudes Towards Inclusive Education. Aust J Teach Educ. 2013;38(4).

61. Boyle C, Scriven B, Durning S, Downes C. Facilitating the learning of all students: The "professional positive" of inclusive practice in Australian primary schools. Support Learn. 2011;26(2):72-8.

62. United Nations. Universal Declaration of Human Rights. 1948. Available from: http://www.un.org/en/udhrbook/pdf/udhr_booklet_en_web.pdf

63. United Nations. Declaration on the Rights of Disabled Persons. 1975. Available from: http://www.ohchr.org/EN/ProfessionalInterest/Pages/RightsOfDisabledPersons.aspx

64. Azzopardi-Muscat N, Funk T, Buttigieg SC, Grech KE, Brand H. Policy challenges and reforms in small EU member state health systems: a narrative literature review. Eur J Public Health. 2016 Dec 1 [cited 2019 Aug 22];26(6):916-22. Available from: https://academic.oup.com/eurpub/article-lookup/doi/10.1093/eurpub/ckw091

65. Azzopardi-Muscat N, Sorensen K, Aluttis C, Pace R, Brand H. Europeanisation of health systems: a qualitative study of domestic actors in a small state. BMC Public Health. 2016 Dec 14 [cited 2019 Aug 22];16(1):334. Available from: http://bmcpublichealth.biomedcentral.com/articles/10.1186/s12889-016-2909-0

66. Thorhallsson B, Wivel A. Small States in the European Union: What Do We Know and What Would We Like to Know? Cambridge Rev Int Aff. 2006;19(4):651-68. Available from: http://www.tandfonline.com/doi/full/10.1080/09557570601003502

67. Haugevik K, Rieker P. Autonomy or integration? Small-state responses to a changing European security landscape. Glob Aff. 2017 May 27 [cited 2019 Feb 16];3(3):21121. Available from: https://www.tandfonline.com/doi/full/10.1080/23340460.2017.1377625

68. United Nations Committee on the Rights of Persons with Disabilities. Convention on the Rights of Persons with Disabilities General Comment No. 4. 2016. Available from: http://www.ohchr.org/Documents/HRBodies/CRPD/GC/RighttoEducation/CRPD-C- 
GC-4.doc

69. Peters S, Johnstone C, Ferguson P. A Disability Rights in Education Model for evaluating inclusive education. Int J Incl Educ. 2005;9(2):139-60.

70. Arksey H, O’Malley L. Scoping studies: towards a methodological framework. Int J Soc Res Methodol. 2005 Feb;8(1):19-32.

71. Levac D, Colquhoun H, O'Brien KK. Scoping studies: advancing the methodology. Implement Sci. 2010 Dec;5(1):69.

72. Mahoney J. Path dependence in historical sociology. Theory Soc. 2000;29(4):507-48. Available from:

http://webarchiv.ethz.ch/soms/teaching/OppFall09/MahoneyPathDependence.pdf

73. Pierson P. Increasing Returns, Path Dependence, and the Study of Politics. Am Polit Sci Rev. 2000;94(02):251-67. Available from:

http://www.journals.cambridge.org/abstract_S0003055400221059

74. Collier R, Collier D. Shaping the Political Arena Critical Junctures, the Labor Movement, and Regime Dynamics in. 2002 [cited 2018 May 15]; Available from: https://cloudfront.escholarship.org/dist/prd/content/qt8qr1z7gc/qt8qr1z7gc.pdf?t=ok97 a8

75. Bandelow NC, Vogeler CS, Hornung J, Kuhlmann J, Heidrich S. Learning as a Necessary but Not Sufficient Condition for Major Health Policy Change: A Qualitative Comparative Analysis Combining ACF and MSF. J Comp Policy Anal Res Pract. 2019 Mar 15 [cited 2020 Jan 24];21(2):167-82. Available from: https://www.tandfonline.com/doi/full/10.1080/13876988.2017.1393920

76. Rihoux B, Ragin C. Configurational Comparative Methods: Qualitative Comparative Analysis (QCA) and Related Techniques. New York: SAGE Publications; 2009 [cited 2020 Jan 28]. Available from: http://methods.sagepub.com/book/configurationalcomparative-methods

77. Ragin CC. The comparative method. Moving beyond qualitative and quantitative strategies. Los Angeles: University of California Press; 1987.

78. Kane H, Lewis MA, Williams PA, Kahwati LC. Using qualitative comparative analysis to understand and quantify translation and implementation. TBM. 2014 [cited 2020 Jan 24];4:201-8. Available from:

https://www.ncbi.nlm.nih.gov/pmc/articles/PMC4041929/pdf/13142_2014_Article_25 1.pdf

79. Verweij S, Gerrits LM. Understanding and researching complexity with Qualitative 
Comparative Analysis: Evaluating transportation infrastructure projects. Evaluation. 2013;19(1):40-55.

80. Schneider CQ, Wagemann C. Set-Theoretic Methods for the Social Sciences: A Guide to Qualitative Comparative Analysis. Cambridge: Cambridge University Press; 2012.

81. Warren J, Wistow J, Bambra C. Applying qualitative comparative analysis (QCA) in public health: a case study of a health improvement service for long-term incapacity benefit recipients. J Public Health (Bangkok). 2013 [cited 2020 Jan 28];36(1):126-33. Available from: https://academic.oup.com/jpubhealth/articleabstract/36/1/126/1571864

82. Ragin CC. Qualitative Comparative Analysis using Fuzzy Sets (fsQCA). In: Configurational Comparative Methods: Qualitative Comparative Analysis (QCA) and Related Techniques. London: SAGE Publications; 2009 [cited 2020 Jan 28]. p. 87122. Available from: http://methods.sagepub.com/book/configurational-comparativemethods/n5.xml 


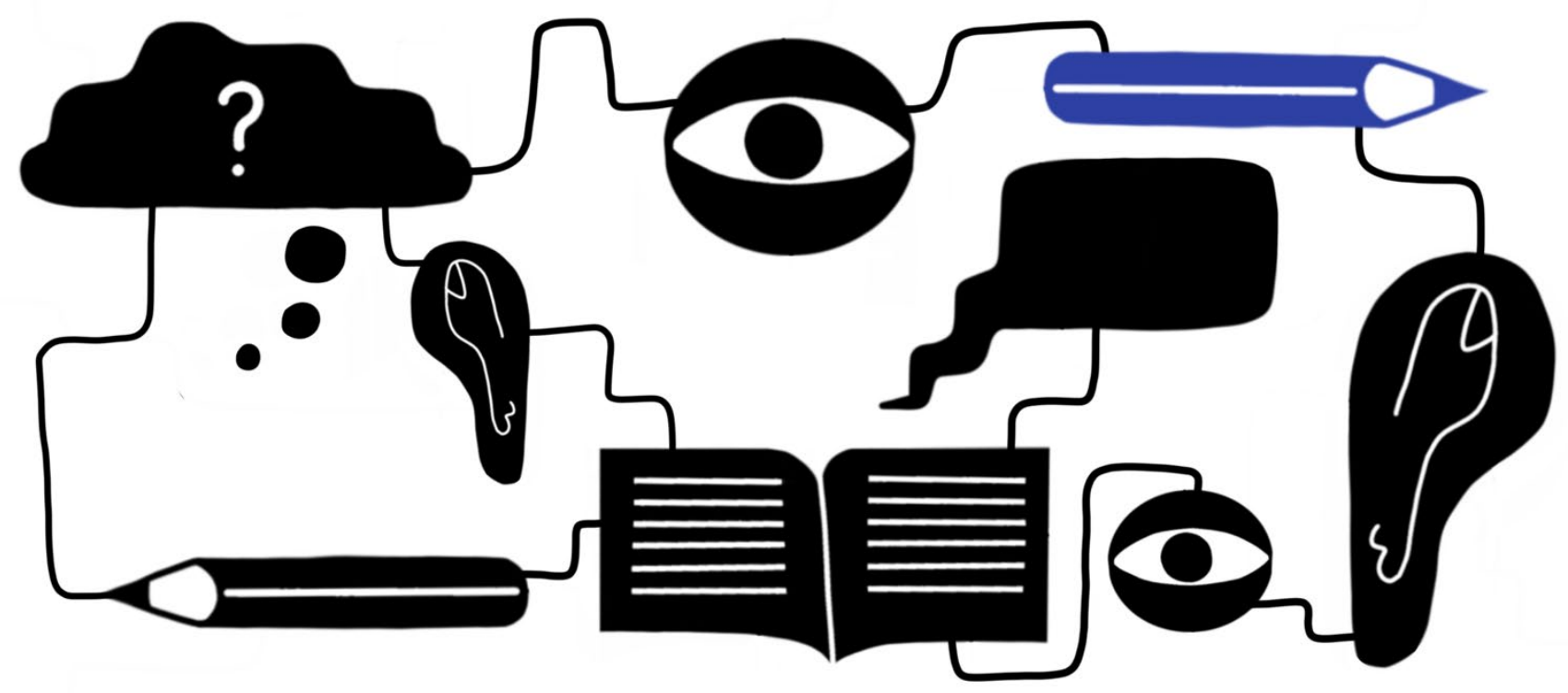

\section{Chapter One}

Family Involvement

\section{Published as:}

van Kessel, R., Roman-Urrestarazu, A., Ruigrok, A., Holt, R., Commers, M., Hoekstra, A., Czabanowska, K., Brayne, C., \& Baron-Cohen, S. (2019). Autism and family involvement in the right to education in the EU: policy mapping in the Netherlands, Belgium and Germany. Molecular Autism, 10(1). DOI:10.1186/s13229-019-0297-x [IF(2019): 5,712] 


\begin{abstract}
Introduction: In recent years, the universal right to education has been emphasised by the Universal Declaration on Human Rights and the Convention on the Rights of Persons with Disabilities. In this paper, we mapped policies relevant to special education needs and parental involvement of children with autism at an international level and in the Netherlands, Germany and Belgium.

Methods: A policy path analysis was performed using a scoping review as an underlying methodological framework. This allowed for a rapid gathering of available data from which a timeline of adopted policies was derived.

Results and Discussion: Internationally, the universal right to education has been reinforced repeatedly and the values of the Universal Declaration of Human Rights have been reiterated with every reinforcement. Also, the additional support that a child with special education needs requires is acknowledged and measures are taken to facilitate access to any education for all children. There are slight cross-country differences between the countries under study, attributable to differences in national regulation of education. However, all countries have progressed to a state where the right to education for all children is integrated on a policy level and measures are taken to enable children with special needs to participate in education. Recently, an attempt to implement a form of inclusive education was made as a form of SEN provision. Nevertheless, nowhere has this been implemented successfully yet.

Conclusion: The Universal Declaration of Human Rights was a critical juncture in international policy and created an environment where the universal right to education has been implemented for all children in the countries under study.
\end{abstract}




\section{Introduction}

Autism Spectrum Conditions (ASCs, henceforth autism) are lifelong developmental conditions that cause difficulties in reciprocal social interaction and communication, alongside unusually repetitive behaviours and narrow interests, sensory hyper- or hyposensitivity, and difficulties in adjusting to unexpected change [1]. Autism affects approximately $1 \%$ of the population with a male-to-female ratio between $3: 1$ and $4: 1[2,3]$. Autistic individuals may be more prone to serious health and other functional difficulties, which may lead to financial problems for families and carers, and can carry considerable stigma [4-7]. To address these issues and increase the quality of life and inclusion of people with autism and the autism community across Europe, the application of fundamental rights of education in the European Union (EU) is paramount [8].

Consequently, it is crucial for EU Member States to provide special education needs (SEN) services from early childhood onward, and throughout school years, while supporting people in life-long education to allow people with autism to achieve their full potential $[2,9]$. Examples of SEN as defined by Carrol and colleagues [10] include linguistic difficulties, problems in communication, or learning disabilities that require additional support provision. Schools play a vital role in the provision of SEN services, such as providing support with language, planning, social interactions, and communication. An example of SEN service provision in schools is inclusive education. For this paper, the term inclusion is best explained by Grindal and colleagues [11]: "a process of systemic reform embodying changes and modifications in content, teaching methods, approaches, structures and strategies in education to overcome barriers with a vision serving to provide all students of the relevant age range with an equitable and participatory learning experience and environment that best corresponds to their requirements and preferences." In other words, the necessary SEN services are provided in mainstream education (conventional education that neurotypical children also attend), along with other structural changes, thus enabling children with autism to participate with their peers $[10,11]$. The vital role of schools is further stressed by the large amount of time children spend in an educational setting and, by extension, the potential that education has as an essential place to address the difficulties that children with autism experience $[10,11]$. Providing these services appropriately and adequately can yield significant short- and long-term benefits for a child's cognitive and social development [11]. Significant improvements in the development of social skills have been found in children with autism attending mainstream or mixed schools [12], with enhanced engagement with the 
environment [13], allowing for opportunities for improvement in independence and selfsufficiency [14]. Furthermore, children that receive proper SEN services are twice as likely to enrol in secondary post-education. For example, in an independent large-scale study in the US [15], with $11 \%$ of children being more likely to be employed [16], and $10 \%$ being more likely to be able to live independently $[12,16]$. Currently, approximately $9.3 \%$ of children receive SEN services in the Netherlands [17], and Belgium is split between $6.2 \%$ in Flanders and $4.5 \%$ in Wallonia [18]. The proportion in Germany is currently unknown, as it has not yet been investigated.

SEN services are implemented differently across countries [19]. In the Netherlands, there is a distinction between mainstream, mixed, and special schools [20]. Within the Dutch system, there are schemes in place that can provide financial support to obtain additional care when attending a mainstream or mixed school. In the EU's largest nation, Germany, the main focus is towards inclusion of all children into a single school system, while also providing special schools for those that find the provision of special needs in mainstream schools to be insufficient [21]. Local and regional dynamics play an important role as, for example, the SEN provision system in Belgium is shared between the regions of Flanders, Wallonia, and the German community [22]. Similarly, each Federal State (Land) in Germany is responsible for their own implementation of SEN services [23]. In Flanders, a clear separation between mainstream and special schools remains, even though new incentives to create room for mixed schools were introduced in 2014 [24]. Wallonia, on the other hand, created a step-wise system of inclusion into mainstream schooling that depends on the ability of a child and the severity of the condition [25].

Family support and engagement in both policymaking and education play a key role in supporting children with SEN and improving health outcomes [26]. For example, Northern Ireland was the first country to explicitly stress the importance of education and policy engagement of family members in their Autism Strategy (2013-2020). The Autism Strategy was aimed at involving parents in the education process of their child with autism [27]. In the National Plan for Autism in Children in the UK, active family involvement was one of the core policy principles in taking care of an child with autism [28]. It specifies that families and carers, in the form of parent-professional partnerships, are involved in the accomplishment of development goals set for the child with autism. The extent to which other Member States in the EU have implemented family involvement in their autism policy in SEN is currently 
unknown, although previous work by Roleska \& Roman-Urrestarazu and colleagues has investigated EU SEN policy overall [29].

This paper is a continuation of the European Consortium for Autism Researchers in Education (EDUCAUS) project [30] and builds upon previous work that started mapping EU SEN policy in all 28 Member States [29,31] by expanding the scope with 3 EU Member States to look specifically at family involvement in autism policy. Through a scoping review, we comparatively assess and map family involvement in EU and local policymaking in the Netherlands, Germany, and Belgium. Both the Universal Declaration of Human Rights (UDHR) [32] and the Convention on the Rights of Persons with Disabilities (CRPD) [33] play a key role in the EU disability policy through their respective endorsement of inclusive education of people with autism and the fact that both documents have been signed by all EU Member States. Therefore, we employ these as underlying principles when conducting the policy path dependence analysis. In doing so, the main policy outcomes are shown, as well as to what extent these outcomes are connected between various levels of policymaking (e.g. international, national, and regional). Ultimately, our goal is to establish a clear policy perspective on how families are integrated in policy that ensures the right to education is established, as well as how SEN interventions might affect public health outcomes for people with autism across three Western EU countries: The Netherlands (17.1 million people) [34], Germany (82.5 million people) [34], which is represented by Bavaria, North Rhein Westphalia, Saxony, and Lower Saxony in this scoping review, and Belgium (11.3 million people) [34], which is divided in Flanders (6.4 million people) [35], Wallonia (3.6 million people) [35], the German-speaking region (75.2 thousand people) [35], and the BrusselsCapital region (1.1 million people) [35]. Since Germany is a federal republic, meaning every Land is responsible for regulating education within its respective territory, Bavaria, North Rhein Westphalia, and Lower Saxony were chosen since they are the largest Länder in terms of population [36]. Saxony, being a former Eastern German Land, was added as a comparison point to account for the former separation of Germany, since it has a population size similar to Lower Saxony. As a result, an adequate representation of the overall German environment is ensured. Further reasons for the selection of these countries are their proximity, similar income levels and standards of living, comparable health and social welfare systems, cultural likeness, their autism prevalence (The Netherlands, $0.6-2.3 \%$, Germany $0.4 \%$, Belgium $0.6 \%$ ) $[20,37,38]$, and their demographic weight. Together, they represent a considerable portion (21.6\%) of the total EU population (511.5 million people) [34] that might be affected 
by autism-specific policies $[39,40]$. A table showcasing all this data is included in an additional file [see Additional File 1]. Ultimately, this study adds to the existing body of literature on autism treatment by providing a social policy perspective. It also adds to the epidemiological body of literature by highlighting differences in vulnerability across countries and, in particular, the need to focus on differential evidence bases for public health policies directed towards different levels of need across different regions.

\section{Methods}

The study uses the policy mapping framework previously used and validated by Roleska \& Roman-Urrestarazu and colleagues [29]. It is well suited for the scope of this research based on the implementation and development of public health policy. Also, a scoping review allows for the rapid mapping of the key concepts underpinning a broad research area that is particularly valuable for complex issues which have not been reviewed comprehensively to date $[41,42]$. In other words, this methodology encompasses the structural and systematic nature that a systematic literature review would bring, while it disregards the quality assessment of data gathering due to the scarce body of existing literature. This scoping review and mapping exercise were conducted by means of a policy path dependence analysis [43]. This methodology is particularly suited for analysing the development of policy based on preexisting legislation (e.g. the UDHR and CRPD) combined with contingent factors, such as external coercive pressure [43]. It also integrates competing ideas and values (e.g. international versus national priorities), which allows for the exploration of interactions among different countries as well as how they follow supranational guidance (e.g. United Nations or EU guidance). Because there is no single, representative data source in the EU with regards to autism and SEN policy, we adopted a modular approach to legislative and policy work across the different educational policy layers of analysis (International, EU, and Dutch, German, and Belgian-specific). We used the PRISMA framework to report our findings [44].

\subsection{Theoretical Framework for Data Analysis and Path Dependency}

An analysis of policy path interdependency was performed drawing on current and past international, EU, and national policies in the field of education and autism. Path dependence technique enables the identification of policy-making patterns and establishes influences and interrelations among policies in linear layers of temporality [43]. It also allows for policy process-tracing, which firstly aims to clarify what factors are present in critical policy 
junctures. Secondly, it aims to create a reference framework and illustrate how decision processes come to conclusions. Thirdly, it aims at clarifying how behaviour that occurs in different stakeholders as a response to external factors (e.g. the adoption of new policy) affects various institutional arrangements (e.g. collaborations between institutions) [45,46]. In this case, the UDHR was the initial policy (1948), a milestone document that influenced both the creation and the content of EU as well as national policies. Time and policy were two variables presented on a timeline to show their linkage and overlap to facilitate further analysis. This enabled us to see policy creation as historical sequences and patterns and identify path dependence [43]. Current disability and autism policies are a result of previous events that were tracked using this framework. Each policy was analysed by identifying its input in the field of education, pros and cons, as well as in relation to other policies.

\subsection{Eligibility Criteria}

Since this report expands the work on EU SEN policy mapping of the 28 EU Member States, the scope of policies was limited to autism and SEN policies that relate to the national education system, the right to education, special needs education, and disability laws. Additionally, policies and documents relating to autism and educational policy of those younger than 18 years, with any comorbid health condition in any setting were eligible for inclusion. Legal documents provided by governments were included, whereas programs and strategies developed by non-governmental organizations were excluded. Furthermore, legislation was eligible for inclusion as long as it was published after 1945. Constitutions were included regardless of publication date, because of their fundamental role in legislation.

\subsection{Data Collection and Search Strategy}

The first step in this policy mapping was to review and extract relevant policies and legislation that address the right to education of people with autism directly from original governmental sources. Several databases were used in the collection of data. The United Nations database (http://www.ohchr.org) was used for the retrieval of its policy documents. Eur-Lex (http://eur-lex.europa.eu) and N-Lex (http://eur-lex.europa.eu/n-lex/) were used to search for EU and national governmental documents respectively. Additionally, Kluwer Navigator (https://www.navigator.nl) was used for more detailed searches in Dutch legislation, JURIS (https://www.juris.de) was used to search for national and regional German legislation, and BelgiëLex (http://belgielex.be) was used to access the Belgian legislation 
(divided in Flanders, Wallonia, and the German community). No limits were put on language. Moreover, no time limit was used during the searches, as the goal was to create a timeline of policies. The second step was to develop a multi-faceted search strategy for electronic databases (PubMed and Google Scholar) that was executed by a single researcher. A selection of key terms was created to use as the foundation of the search terms: "autism; disability; SEN; education; law; policy; right to education; special needs; special education; inclusive education". Next, the academic databases PubMed and Google Scholar were searched using the following combinations of search terms: "autism \& disability"; "autism \& SEN"; "autism \& education"; "autism \& law"; "autism \& policy"; "SEN \& disability”; "SEN \& law"; "SEN \& policy"; “disability \& law”; “disability \& policy”. The final search query is shown in Table 1 , along with its constituent terms. The national policy depositories were searched using the separate key terms, as combining the search terms yielded little results. Adaption of the policy search strategy was done through the translation of the search terms in Dutch, German, and French respectively. The third step consisted of merging policy and academic publications according to the eligibility criteria. The fourth step was acquiring further information through searching reference lists and grey literature (e.g. the website of the European Agency for Special Needs and Inclusive Education and the Eurydice Network [47,48]). Policy documents and governmental strategies in the countries under study were compared to the EU disability and educational policy. In case documents were not present, general disability policies and legislation were analysed. The data collection was built on the appraisal of three searches: one looking for autism and educational policy internationally, one at the EU level, and one at the national level. In the cases of Germany and Belgium, the sub-national level was analysed as well, considering their identity as federal states. The final step was unifying the three searches into one single data repository for the purpose of the scoping review. The final dataset was then verified by both lead authors to maximise screening reliability.

Table 1. The build-up of the final search query for academic databases.

\begin{tabular}{|l|l|}
\hline & Search Query \\
\hline Term 1 & $\begin{array}{l}(((((((((\text { autism \& law) OR autism \& policy) OR autism \& SEN) OR autism \& education) } \\
\text { OR autism \& disability) OR SEN \& policy) OR SEN \& law) OR disability \& law) OR } \\
\text { disability \& policy) })\end{array}$ \\
\hline Term 2 & $\begin{array}{l}((\text { Netherlands OR Belgium OR Germany) }) \\
\text { Final Query }\end{array}$ \\
$\begin{array}{l}\text { OR autism \& disability) OR SEN \& policy) OR SEN \& law) OR disability \& law) OR } \\
\text { disability \& policy) }) \text { AND ((Netherlands OR Belgium OR Germany) })\end{array}$ \\
\hline
\end{tabular}




\section{Results}

We identified 661 sources through academic database searching and 1169 through policy databases. A PRISMA flowchart illustrates this process in Figure 1 where policy databases are referred to as 'other sources'. Four duplicates were identified and removed, leaving 1826 sources to be analysed using the eligibility criteria. After analysing titles and abstracts, 115 sources were considered eligible for full-text screening. An example of an excluded item is the annual report on the overall spending of the Ministry of Education. It matches the search criteria (keyword 'Education'), yet does not fall within the scope of this report, since it is not directly policy-related. The full-text screening resulted in the exclusion of another 60 articles, due to lack of relevance, difference in scope, and unavailability of the full text. The remaining 55 articles were included in the scoping review. It has to be noted that the number of documents identified through policy searches far exceeds the number that was found using the academic databases. There are two explanations for this: (1) the two databases were searched using different search terms, as the search terms for the academic databases were not transferable to the policy databases and the single key terms had to be used to access the data; and (2) the current body of literature on SEN policy is still heavily in development. 


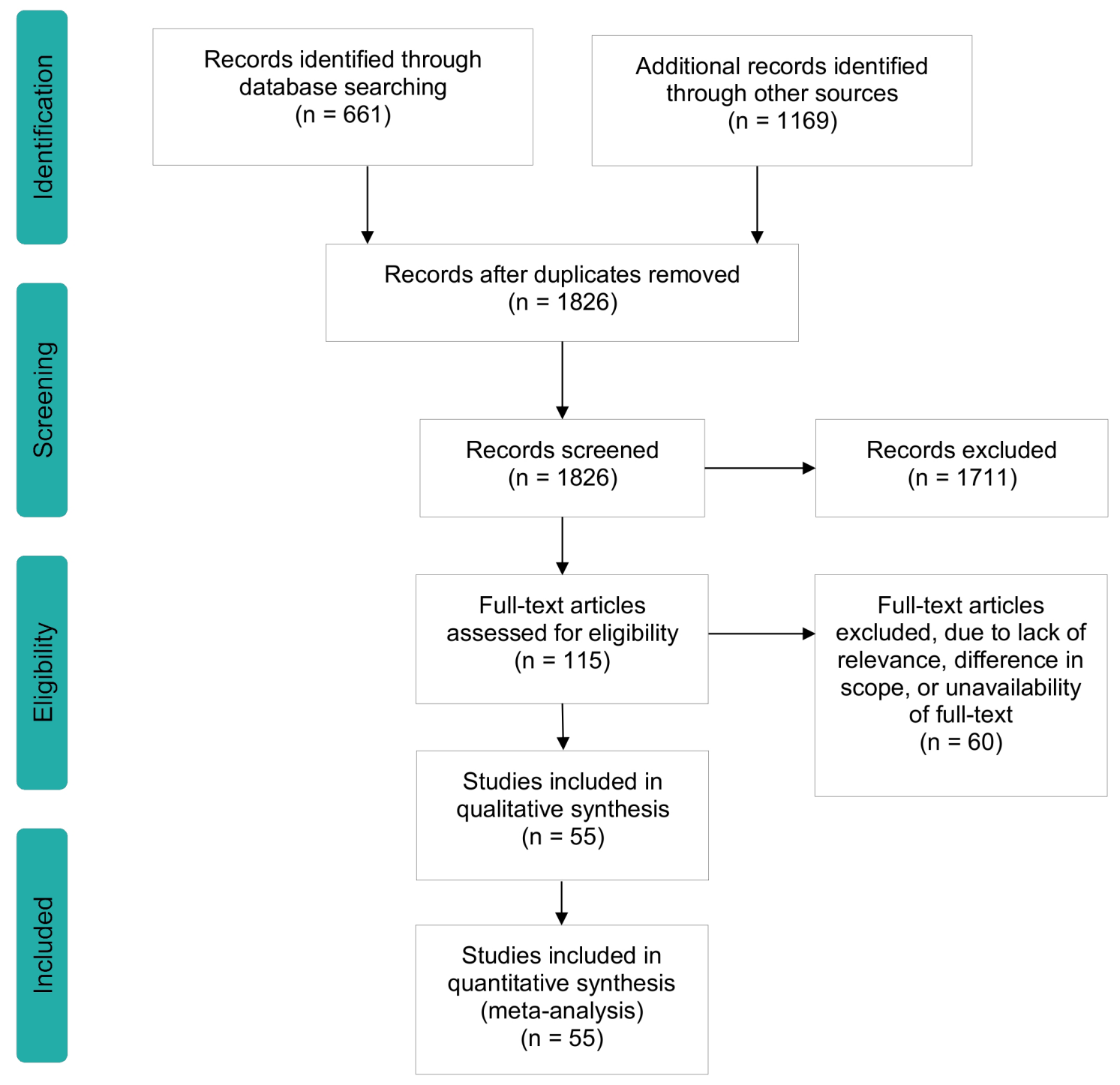

Figure 1. An overview of the data collection process.

A timeline was constructed to illustrate the adopted policies relating to family involvement and right to education in autism, both internationally and nationally. Figure 2 illustrates the timeline of the international policy, while Figures 3 captures the timelines of the individual countries. A concise overview of the findings is provided in two additional tables (see Additional File 2 and Additional File 3). The preeminent act that stresses the importance of right to education is the UDHR [32]. It stipulates in Article 26 that everyone is entitled to free education in the elementary and fundamental stages and that education should be aimed at fully developing the individual. This right is expanded in the Declaration on the Rights of the Child [49], where Article 24 states that special needs of children should be met when it comes to treatment, education, and care. Finally, the CRPD emphasises that children with disabilities should be able to fully enjoy all human rights and fundamental freedoms on an equal basis 
with other children, thus including the right to education once more as one of its central tenets and therefore cementing any future development of children and people with disabilities and their right to education [33].

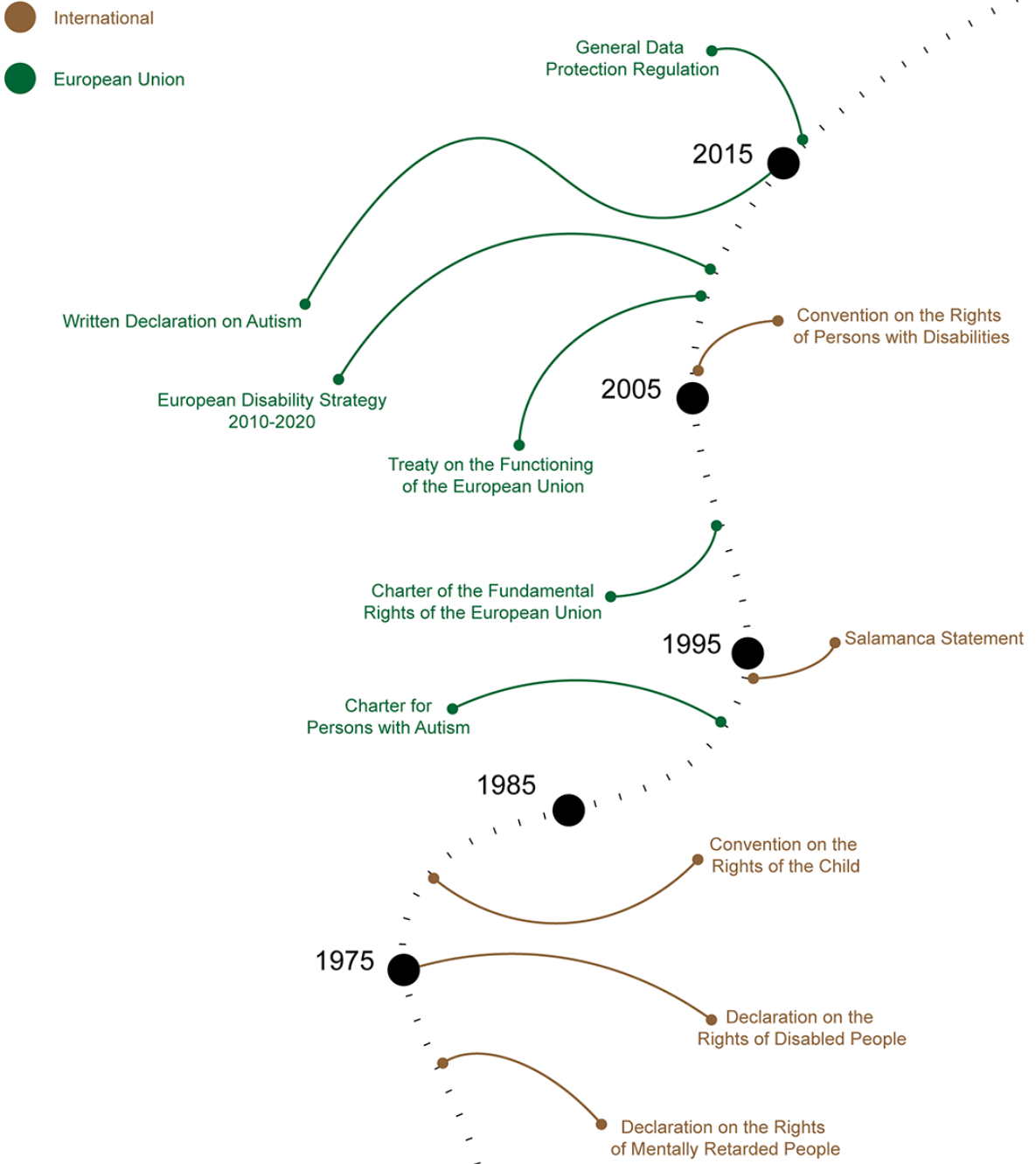

1965

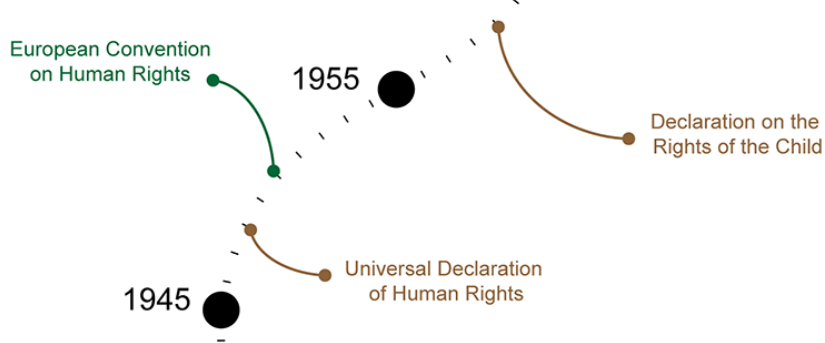

Figure 2. A chronological illustration of international and EU policies in the field of SEN. 


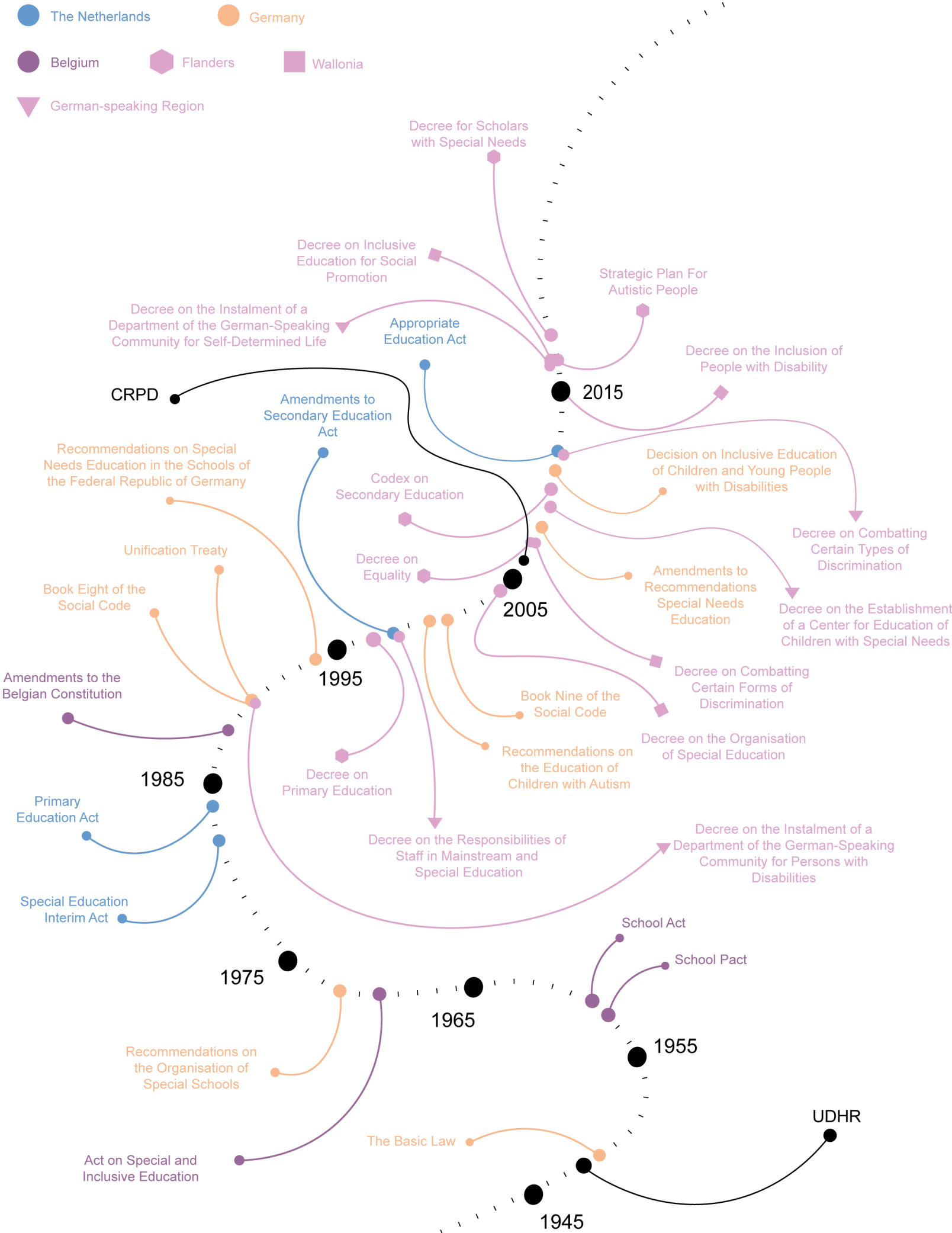

Figure 3. An illustration of all included national and subnational policies with regards to SEN. 


\subsection{International Policy}

The UDHR can be considered the critical juncture upon which the current SEN policy environment is based, since it is the first international document to specify the right to education for everyone, the right for each individual to fully develop his or her potential, and the right of parents to be included in the educational process of their child. While the UDHR acknowledges that everyone has the right to education, the United Nations also acknowledges that children may require special care and support [49]. Consequently, the Declaration on the Rights of the Child was adopted in 1959. In the fifth principle of this Declaration, it is explicitly stated that a child who is physically, mentally, or socially handicapped should be given appropriate treatment, education, and care that matches the particular condition. After the adoption of these two legislative acts, children with special needs in all signatory countries were entitled to education without discrimination based upon, for example, their disability or autism status. While there was a solid foundation for general human rights at this point, the rights of people with disabilities was not specifically addressed. This changed with the adoption of the Declaration on the Rights of Mentally Retarded Persons in 1971 and the Declaration on the Rights of Disabled Persons in 1975 [50,51]. Article 2 of the Declaration on the Rights of Mentally Retarded Persons stresses the right of people with intellectual, developmental, and learning conditions specifically to receive appropriate education in order to develop themselves to their maximum potential [50]. In addition, Article 4 covers the necessity for people with neurodevelopmental conditions to live with their own family where possible, as well as the need for the families with whom they live to receive assistance. Nevertheless, the scope of this Declaration is limited to people with intellectual, developmental, or learning conditions only. The Declaration on the Rights of Disabled Persons was signed shortly after to expand this scope to people with disabilities in general [51]. The definition of 'disabled person' that was established in this Declaration allowed the inclusion of autism as a disability. The Convention on the Rights of the Child expands on the principles of the Declaration on the Rights of the Child and the rights and duties of the parents to provide direction to the child with regards to its development [52]. After its adoption in 1989 , the role of the parents in the development of their child was closely explained from a human rights perspective. Previously, it had only been established that parents play a general role in the development of the child. Moreover, United Nations Educational, Scientific and Cultural Organization (UNESCO) published the Salamanca Statement in 1994 [53], which reemphasises the fundamental right to education for every child. Moreover, the Statement acknowledges the unique characteristics and learning needs for every child and calls for 
education systems to be designed to take this wide diversity of characteristics and needs into account, making it so that children with SEN can follow mainstream education with additional supportive services.

\subsection{European Union}

Shortly after the adoption of the UDHR by the United Nations, the Council of Europe adopted the European Convention on Human Rights in 1952. Its Protocol laid down the right to education for every person in what later came to be the European Union [54]. As a response to the shift of the international discussion on human rights to rights for persons with disabilities, the Charter for Persons with Autism was created in 1992 by Autism-Europe and was adopted as a Written Declaration by the European Parliament in 1996 [55]. It directly refers back to the Declarations on the Rights of Mentally Retarded Persons and the Rights of Disabled Persons. Furthermore, its scope is specifically aimed at people with autism, as it emphasises their rights to accessible and appropriate education (Point 3) and the equipment, assistance and support services necessary to live a fully productive life with dignity and independence (Point 6). When the Treaty of Amsterdam was signed in 1997, the aim to combat any form of discrimination was reiterated once again, while explicitly specifying discrimination on basis of disability (Article 6a) [56].

With the adoption of the Charter of Fundamental Rights of the European Union in 2000, all rights and freedoms that were previously protected by different legislative pieces were pooled into one legally binding document in an attempt to create a closer Union with common values (Preamble) [57]. The right to education for everyone is stated in Article 14, although disabilities and autism are not specifically mentioned in this document. However, it does state that the pedagogical convictions of the parents need to be respected with regards to the education of the child, as long as it remains in accordance with national laws. When applied to the case of SEN service provision, it would allow parents to adopt a decisive role when choosing the form of education, as long as it remains within the boundaries of national law. Additionally, the competence of education was delegated completely to the EU Member States after the ratification of the Treaty on the Functioning of the European Union (2009) [58]. It states that the role of the EU is to encourage cooperation and provide support where necessary (Article 165). This would allow every Member State to regulate its own education system and, by extension, its approach to SEN. However, in doing so, it creates a 
heterogeneous environment in the approach to SEN service provision, as education systems vary from country to country.

The European Disability Strategy 2010-2020 builds upon the Charter of Fundamental Rights of the European Union, the Treaty on the Functioning of the European Union, and the Convention on the Rights of Persons with Disabilities. The Strategy aims to empower people with disabilities so that they can enjoy their full rights. It acknowledges that children with disabilities are often not included in mainstream education and calls for them to be integrated appropriately through the use of inclusive education, along with individual support [8]. Additionally, the Written Declaration on Autism was adopted by the European Parliament in 2015 [59]. It calls for an EU Strategy on autism specifically, as it recognises that early detection is still lacking across Europe, despite the importance of early diagnosis to provide appropriate and adequate support and education (Point 3). Furthermore, it attempts to encourage research on autism, prevalence studies, and exchange of best practices regarding evidence-based interventions for children with autism, as well as support services and services for adults that teach and improve their skills for addressing and coping with autism in daily life (Point 5). Finally, with the introduction of the General Data Protection Regulation in 2018 [60], the data on health conditions is prohibited to be used in any way without the consent of the parents or guardians (Article 9). As a result, implementation of SEN services has become more complex when it involves multiple stakeholders, as health data cannot be shared as freely as before. Consequently, the institution that is responsible for the provision of SEN services is tasked with the collection of informed consent of the parents before the process of determining appropriate SEN services based on the condition of the child can be started.

All in all, EU legislation early on mainly focused on creating a binding basic human rights framework. Autism has also been acknowledged early on in the history of the EU as part of establishing rights for people with disabilities. However, further action on empowering people with autism did not happen until the EU Strategy in 2010 and the Written Declaration in 2015. Finally, the focus of EU legislation is put predominantly on the individual with disability, while the direct environment is mostly disregarded so far.

\subsection{The Netherlands}

Compulsory education has been implemented for all children in the Netherlands since 1901 [61]. This education takes the form of mainstream schooling or home schooling. A framework 
for schools that focus specifically on special education is laid down in the Special Education Interim Act (ISOVSO, 1982) [62]. With this Act, special needs were first recognised and addressed within the Dutch education system. It also acknowledges the importance of the role of the parents by implementing pathways for the parents to partake in the education of their child, while simultaneously being educated themselves on their child's condition (Articles $41 \mathrm{a}(4), 44$, and 48). The role of the parents is mainly supportive, since the way of teaching is structured in the Act. Consequently, primary education was split between mainstream education and special education, with both being regulated by the government. The separation facilitated the inclusion of all children ages four to twelve in the education system. Amendments to the Secondary Education Act in 1998 resulted in the coverage of secondary special education for children with learning and behavioral difficulties and for students with moderate learning difficulties [63]. The educational trajectory for all children aged four to eighteen was henceforth determined by three legislative acts, namely the Primary Education Act for mainstream primary education, the Secondary Education Act for secondary mainstream and special education, and the Expertise Centers Act (previously ISOVSO) for special primary education. In an attempt to integrate special education into mainstream education, major reforms were made to these three Acts in 2012 in the Appropriate Education Act [64]. The reforms were aimed at broadening the scope of provision of services from carebased to support-based. This implied that the provision of special needs services was no longer restricted to medical needs. Instead, it could now address the full range of special education needs that limited children from fully participating in the education system. Nevertheless, there are still major barriers to the implementation of inclusive education.

A notable characteristic of the education system in the Netherlands is the freedom for any person to start a school and, by extension, organise its teaching, and determine the ideological, educational, and religious principles on which the teaching is based. This freedom was included in the amendments to the Dutch Constitution in 1917 [65]. As a result, the Organisation for Economic Co-operation and Development (OECD) reports a high number of schools (especially primary schools) with a subsequent high diversity in educational perspective [66]. In order to determine the appropriate governmental funds for such a high number of different schools, the OECD reports that the Netherlands has adopted a scheme where the funds that a school receives is based on the number of students enrolled in that institution [66]. However, when relating back to the provision of SEN support in schools, this 
disadvantages schools smaller in size, as they receive less funding out of this scheme, while the costs of the SEN support provision remain the same.

Ultimately, SEN education in the Netherlands is fully integrated in national legislation and there is no specific action plan or strategy with regards to autism. Also, the universal right to education was addressed implemented well before the UDHR was established and adopted. The funding scheme can be considered a weakness that can form a barrier in the provision of SEN support, which applies mostly for smaller schools. Parental involvement is largely expressed through the freedom of choice of schools, especially primary schools. The law states schools should involve parents in the educational trajectory of children with SEN, yet there are no concrete guidelines in this regard. Schools can decide this for themselves.

\subsection{Germany}

The right to equal treatment of people with disability is highlighted in Article 3 of the Basic Law (1949) [67], which was signed a year after the implementation of the UDHR. It also lays down the foundations for a system for special education in Article 7, while declaring in the same Article that the regulation of the education system is a responsibility of the Länder. At this point, the Basic Law only applied to the Federal Republic of Germany. The Basic Law became binding for Länder within the previous German Democratic Republic after the adoption of the Unification Treaty in 1990 [68]. In addition to the Basic Law on national level, each Land has its own constitution as well. For example, when Bavaria adopted its constitution in 1946 [69], it already included the right to education for all (Article 129). In North Rhein Westphalia, where the constitution was adopted in 1950, it states that every child has the right to education (Article 8), as well as that parents have the right to determine the education of their children, which forms the foundation of the education and school system (Article 10). The constitution of Lower Saxony was made to closely resemble the Basic Law in 1951 [70]. Because of its close resemblance, it avoided repetition of, for example, civil rights that were already mentioned in the Basic Law. Therefore, the right to education is not included in this document. Finally, since Saxony was part of Eastern Germany, which fell under the Soviet regime, it did not have a constitution comparable to the one in Western Germany until the first version was implemented in 1992 [71].

The education systems for the Länder are specifically laid down in their respective Education Acts (Bavaria, Article 19 [72]; North Rhein Westphalia, Article 20 [73]; Saxony, Article 13 
[74]; Lower Saxony, Article 14 [75]). While each Act acknowledges the existence of SEN schools and their importance, there are slight differences in the regulation on how these schools should be implemented. Bavaria (Article 2), North Rhein Westphalia (Article 20), and Lower Saxony (Article 4) aim at including as many children in mainstream education and providing SEN services there, while still retaining specific SEN schools for children that are unable to attend mainstream education due to their disability. In contrast, the system in Saxony remains strongly split between mainstream and special education with the only overlap being the degrees that can be acquired. There are also other subtle differences between the Education Acts. Firstly, the Education Act of Bavaria lays down the conditions for a child to be eligible for admission into a SEN school in Article 19, stating that access is warranted when either a child cannot be supported or insufficiently supported and taught in mainstream education. Next, Article $30 \mathrm{~b}$ discusses the aim to include as many children in mainstream education as possible, providing special education services where applicable and necessary. It also emphasizes the right of parents to choose the type of school for the child in Article 44. Secondly, the Act of North Rhein Westphalia provides a specific definition of SEN, the general conditions for which SEN services are provided, and the role of the educational institution towards the parents in Article 19. Article 20 specifies that the parents can deviate from the SEN service provision in mainstream schools and send the child to a special school. Thirdly, the Education Act of Saxony incorporates counseling centers in SEN schools in Article 13, whose responsibility is early detection and facilitate early interventions for children with disabilities, as well as offer disability-specific counselling for parents and teachers. Notably, active parental involvement is not included in this Education Act. Finally, the Education Act of Lower Saxony is similar to the Acts of Bavaria and North Rhein Westphalia, except that it provides an in-depth description on the establishment of inclusive education (Article 183c).

Even though the competence of education lies with the Länder, the Standing Conference of the Ministers of Education and Cultural Affairs (SCMECA) harmonised the development and organisation of special education by adopting several resolutions, most notably the Recommendations on the Organisation of Special Schools in 1972 [76]. Book Eight of the Social Code (1990) implemented youth services to assist parents in the development of the child and to support the child in his or her development and education [77]. It also identifies a wide range of supporting services in Articles 27 through 40 that can be used to provide assistance, based on the condition of the child with special needs and the environment it lives 
in. In Chapter 3 of the Recommendations on Special Needs Education in the Schools of the Federal Republic of Germany (1994) [78], developments were formulated that aimed to dismantle barriers and promote the equal participation of young people with disabilities in mainstream education and special education. Additionally, schools were given part of the responsibility to involve and educate parents with regards to the condition of their child and how to address this condition adequately outside of school. It also addresses the crucial role of the parents in helping a child establish sustained relationships with others over time. The SCMECA published recommendations on the education of children with autism in 2000 [79]. This document addresses the diagnostic criteria to be used for autism in schools in Chapter 3 , the goals for the education system in general in Chapter 4, and the key points for every educational institution separately in Chapter 5. Book Nine of the Social Code on the rehabilitation and participation of people with disabilities (2001) specify in Articles 46 and 79 that early medical screening intervention is paramount in addressing disabilities as adequately as possible [80]. The term "medical screening" does include non-medical social-paediatric, psychological, curative, psychosocial services and counselling of guardians using interdisciplinary services and facilities. Book Twelve of the Social Code, adopted in 2003, adds that the special circumstances in the family of the beneficiaries should be taken into account in the case of social assistance benefits [81]. Social assistance should encourage the family to help themselves and consolidate the cohesion of the family. In 2008, the SCMECA decided to amend the Recommendations on Special Needs Education in the Schools of the Federal Republic of Germany in order to respect the intentions of the CRPD in the Länder. The SCMECA adopted the Decision on Inclusive Education of Children and Young People with Disabilities in schools in 2011 [82]. The aim was to enable children and young people to be educated and trained together in mainstream education and to guarantee and develop the standards achieved in special education teaching, advisory, and support services.

Even though German SEN policy is harmonised, it still gives sufficient room for interpretation for the Länder, resulting in subtle differences. Saxony is notably less developed in terms of SEN policy, possibly because of the separation between Western and Eastern Germany after the Second World War and consequently differential development of their respective educational systems. With the Basic Law of the Federal Republic of Germany becoming binding for all of Germany since 1990, former Eastern German States were incentivised to develop similarly to Western Germany. Additionally, the provision of support and education for parents on the SEN or disability of the child is regulated through the 
harmonised law, yet the active involvement of parents in education is generally limited to the decision on school choice.

\subsection{Belgium}

The right to education for all has been included in the Belgian constitution since 1831 (Article 24) $[83,84]$. Over time, the regulation of education has been an area of tension in Belgium, as the government, linguistic communities, and the church struggled for power. This struggle ended with the adoption of the School Pact in 1958 [83]. In the School Pact, a division was made between state-regulated schools and schools that were led by non-governmental institutions. Consequently, the School Act, adopted in 1959, laid down the foundation of all primary and secondary education systems in Belgium, including special education [85]. The need for special education for people with physical and mental disabilities started developing once the right to education for everyone was implemented [83]. This resulted in the adoption of the Act on Special and Inclusive Education in 1970 [86], which laid down the conditions under which children would be eligible to attend special schools, as well as the organisation of various levels of education. The amendments to the constitution of Belgium in 1988 resulted in the delegation of the competence of education to the individual regions in Belgium (Flanders, Wallonia, and the German speaking community) [22]. The right to education remained emphasised in Article 24. However, the article was expanded with the notion that parents have the ability to decide on the education of their child in order to guarantee his or her development [84]. Even though Belgium recognises a fourth legislative region (the Brussels-Capital region), it does not formulate its own legislation regarding education. Instead, it is a combination of the Flemish and the Wallonian system, depending on the core language of the school (e.g. Dutch-speaking schools fall under the Flemish system, while French-speaking schools belong to the Wallonian system) [87].

\subsubsection{Flanders}

The Decree on Primary Education, signed in 1997, built upon the foundation laid down by the Act on Special and Inclusive Education and states in Article 8 that mainstream education is responsible to educate all students between the ages of six and twelve and that schools can opt into a systematic and transparent cooperation with parents in case of additional needs [88]. Article 9 then explains that special education is provided to children whose development cannot be guaranteed by mainstream education, with Article 10 differentiating the several types of special education, taking the needs of the child into account (e.g. whether the child 
has an intellectual disability, impairment in motor skills, or autism). The CRPD is directly referenced in national law in the Decree on Equality, signed in 2008. The Decree states that any form of discrimination in the sector of education is prohibited in Article 20 [89]. Special education services in secondary education were implemented in 2010 through the ratification of the Codex on Secondary Education [90]. Article 357 specifies that SEN support can be provided for children that are able to partake in mainstream education [90]. Furthermore, parents are involved in the expansion of care based on SEN of the child, according to Article 3(44). The involvement includes both the care aimed from the parents to the child as well as the assistance a school can offer the parents. With the adoption of the Decree for Scholars with Special Education Needs was adopted in 2014 [91], measures were taken to create a more inclusive environment in primary and secondary education. The measures aimed to allow children with SEN to participate fully, effectively and on equal terms in mainstream education. Finally, a strategic plan for people with autism was passed by the Flemish Parliament in 2017 [92]. This strategic plan was developed in close relation with parents, using their insight to formulate the aims and goals of the plan. It aims to create and increase the opportunities for people with autism to actively participate in society and to increase their quality of life through the establishment of four principles: (1) the establishment of actions designed to be executed by people with and without autism; (2) participation and inclusion of people with autism in general society; (3) shared engagement between stakeholders; (4) and the investment on a select few interventions that have a clear focus and appropriate scale.

Ultimately, SEN service provision and right to education are repeatedly addressed in education policy. While a division between mainstream and special schools remain, actions have been put forward to develop a more inclusive school system, where segregation is less pronounced. Also, with the adoption of the autism-specific strategy, the needs of people with autism are recognised with an aim toward improvement. However, legislation has not incorporated a clear definition of the responsibilities for the diagnostic process of SEN. It only implies (rather than specifies) that mainstream schools are responsible for this, since this is the place where children can opt into additional support as well. Furthermore, mainstream education encourages parents to engage in the development of the child by providing education on SEN as well as counselling services. 


\subsubsection{Wallonia}

The Act on Special and Inclusive Education was followed by the Decree on Primary Education in 2004 [93], which regulates and implements special primary and secondary education specifically for children with SEN. It states in Articles 25 (primary education) and 65 (secondary education) that a child can switch from a SEN school to a mainstream school based on the decision of the parents, given that the SEN school approves of this decision. The necessity of consent from the parents in the integration of the child with SEN into regular education is expressed in Article 134. Much like the Decree on Equality in Flanders, the Decree on Combatting Certain Forms of Discrimination, signed in 2008, specifies that discrimination on grounds of disability in the sector of education is strictly prohibited [94]. In doing so, it implements the aim of the CRPD in Wallonian law, although the CRPD is never directly referenced in the Decree. In 2014, the Decree on the Inclusion of People with Disability was ratified, which directly references the CRPD [95]. It specifies the responsibilities of support services towards children with disabilities in educational and extracurricular settings in Article 42. Article 43 specifies the scope of the support services by formulating four broad target groups. Children who belong to those groups are considered eligible for the support services specified by this Decree. Finally, the Decree on Inclusive Education for Social Promotion was signed in 2016 with the aim to include more children with SEN in mainstream education [96]. It acknowledges in Article 7 that SEN support can be materialistic, pedagogic, or organisational, as well as specifies that inclusive education is best achieved by working towards the developmental goals that are set for the children with disabilities, rather than question those aims.

In short, while the education system in Wallonia started with a strict division between mainstream and special schools, recent legislation has aimed at bridging these two in order to create an environment of inclusive education. The right to education is notably less stipulated than in Flanders. Nevertheless, it is repeatedly reinforced by the adopted legislation on SEN. Additionally, parental involvement is limited, as it is only incorporated in the school choice of whether a child should switch from one education form to another, yet the latter still requires consent from the school that is currently attended. Furthermore, unlike the case in Flanders, there is no strategy in place that specifically focuses on the improvement of the environment for people with autism. 


\subsubsection{German-speaking region}

In 1990, a social service for people with disabilities was implemented through the Decree on the Installment of a Department of the German-Speaking Community for Persons with Disabilities [97]. This decree states in Article 4(4) that the aim was to offer early support for children with disabilities and their families, along with supporting the uptake in social systems, like the education system. However, due to the wide scope of this decree, it did not elaborate on specific parts of education (e.g. special needs education). A decree that regulates the responsibilities of staff in mainstream education was signed in 1998 [98], although specific parts of the decree are reported in Article 1 to be applicable to special education as well. In Article 23, it is stated that parents that raise the child can decide on the education trajectory of the child (being mainstream education, special education, or home-schooling). Additionally, Article 24 specifies that special needs support may be provided through a collaboration of multiple institutions with the aim to coordinate and complement the education provided. This was followed by the Decree on the Establishment of a Center for Education of Children with Special Needs in order to Improve Education for Children with Special Needs in 2009 [99]. The Center for Education for Children with Special Needs is introduced and regulated in Article 5. Article 6 specifies that the responsibilities include the provision of support to children with SEN in primary and secondary education, as well as to provide assistance to mainstream schools in order to improve the quality and inclusivity of education for children with SEN. Furthermore, Article 16 amends the aforementioned Decree of 1998, installing the aim of education for children with SEN, which is to enable them to live an independent and social life. On top of that, it formulates a clear definition of children with SEN and specified the responsibilities of school staff towards the parents that raise the child. Article 17 then amends the Decree on Primary Education to facilitate better distribution of resources based on the distribution of children with SEN. Following the aims set in the CRPD, the Decree on Combatting Certain Types of Discrimination was implemented in 2012 [100]. In Articles 3 and 4, it is stated that any form of discrimination on the grounds of disability is strictly prohibited in the education sector. Finally, the Decree on the Instalment of a Department of the German-Speaking Community for Self-Determined Life was ratified in 2016 [101]. It refers directly to the CRPD and replaced the Department of the GermanSpeaking Community for Persons with Disabilities installed by the decree in 1990. With the instalment of this department, the scope was increased significantly compared to its previous iteration, as is specified in Articles 6 and 11. More specifically, Article 6 states that the responsibilities towards the general public include creating awareness for SEN and its current 
support provision, as well as to conduct research to improve these services moving forward. Article 11 proceeds to specify that the responsibilities of the department towards children with SEN focus on providing guidance and support in their development, education, and social integration.

In summary, the provision of SEN services is largely disconnected from the education system. Since the division of Belgium in three legislative areas, a separate institution has been put in charge of this provision in the German speaking community. This separation of SEN service provision is reinforced repeatedly by newly adopted legislation, with the only exception being the adoption of the decree in 2009 , which had as an aim to facilitate a better environment for inclusion in education for children with SEN. This creates a situation unique to the German community in Belgium, where schools are not in charge of the provision of SEN services, yet still have to facilitate a learning environment to incorporate them. Moreover, parental involvement has received little attention in the adopted legislation. The only statement of active parental involvement was the right to decide in which school a child will be enrolled. However, parents are taken into consideration when it comes to the implications of raising a child with SEN, as the independent institutions that provide SEN also have the responsibility to provide information and guidance to parents. Finally, the general public is put in a position to be more cognisant of the impact of SEN on children and their families when compared to Flanders and Wallonia, because recent policy adoptions have included measures to raise awareness on SEN and its implications.

\section{Discussion}

This study aimed to map relevant autism and SEN policies in the Netherlands, Germany and Belgium and to investigate to what extent family was involved in the provision of special needs and the creation of SEN policy on autism nationally and internationally. In doing so, we found that all regions under study have taken significant action to empower children with SEN in their development. Additionally, the critical role of parents in the development of children with SEN is acknowledged by the UN and all Member States under study. Interestingly, there is very little mention of parental involvement in EU legislation.

Firstly, the UDHR can be considered the critical juncture that led to the current state of universal right to education internationally and in the three countries under study. Since the adoption of the UDHR, legislative documents have referred to and reinforced the right to 
education for everyone nationally and internationally by implementing measures to allow children from all backgrounds and with any condition or disability to access the education system. More specifically, the implementation of the universal right to education started with the adoption of the Special Education Interim Act in the Netherlands, the consecutive measures to harmonise special education across Germany in order to make education more accessible for children with SEN, and the ratification of the Act on Special and Inclusive Education in Belgium respectively. After several decades of implementing and regulating access to education for everyone nationally, the CRPD was adopted and proceeded to emphasise children with SEN as core recipients of the universal right to education. As a response, the countries under study aimed to adopt a system of inclusive education, where children with and without SEN could participate in education together. In hindsight, the adoption of the UDHR and CRPD have set the pathway for the current environment of the right to education. In terms of family involvement, it is interesting to note that $\mathrm{UN}$ policy recognises the importance of family in the development of children with disabilities, yet it remains untranslated in the EU initiatives. Regardless, the countries under study do mention parents in their policy to various degrees, which will be discussed later.

Secondly, legislation that focuses specifically on SEN or developmental conditions acknowledges the barriers to implementing inclusivity in mainstream education and aims to target these barriers by implementing respective measures, such as assisting mainstream schools in the provision of SEN services and providing education for teachers and parents on the implications of having SEN as a child.

Thirdly, the responsibilities of providing SEN services is almost unanimously within the school system, with the only exception being the German speaking community in Belgium. Consequently, financing schemes for schools have become more relevant for the provision of SEN systems. Taking the Netherlands as an example, schools receive funding based on a capitation formula of the number of children that attends a school, while the costs of providing SEN services remain the same. Consequently, schools that have a lower number of attending children are disadvantaged due to receiving less funding, while it is expected of them to offer similar quality of education to all attending children. For them, the financing mechanism forms a significant barrier to providing SEN services. On the other hand, schools that have a high number of attendees will have a comparatively easier time financing additional services for children with SEN. 
Fourthly, family involvement in mainstream education is generally limited to the parents or guardians of the child, who receive the right to choose the type of school that their child attends. In the legislation on special needs education, the education of parents has been acknowledged as an important element and is often facilitated by the institution that is responsible for the provision of SEN services. Furthermore, parents in the Netherlands and Flanders are included in the provision of SEN services, taking on a supportive role, while the other countries or regional governments do not include them in the provision of SEN services, but only educate them on how to address the SEN outside the school environment. Finally, the introduction of the General Data Protection Regulation has formed new barriers to take into account when implementing SEN services, which can hinder the access to education for children with SEN.

There are some contrasts that need to be addressed as well. Firstly, the definition of SEN that is implemented in the legislation of some countries under study does not refer to a common consensus of a definition for SEN. Therefore, it is possible that a heterogenous cross-country environment is created where one country may identify SEN different from another. Secondly, the responsibility for policy making in education lies on different levels in the countries under study. The Netherlands decides and implements nationally, Germany decides nationally, but the Länder have to implement in regionally, and Belgium decides and implements regionally. The difference in these approaches is that regions that are relatively small (like the German-speaking community in Belgium) or come from a different legislative background (like Saxony in Germany) are put in a position where priorities need to be considered when allocating time and resources to a relatively small group of people. When looking at the German-speaking community, specifically, it becomes apparent that every adoption of new legislation is preceded by an adoption of binding legislation by the $\mathrm{UN}$ or EU.

When examining the influence of the UDHR more closely, it becomes apparent that the values of the UDHR have been integrated in every constitution under study and have been repeatedly referred to and reinforced by the subsequent policy adoptions, especially policies that address right to education and empowerment of people with disabilities. The Charter on the Fundamental Rights of the European Union, upon adoption, became binding in its entirety for all EU Member States, ensuring the adoption of the legislation pooled into this document 
at national level. Furthermore, the CRPD has been widely referenced and implemented in education policy of Member States. The Salamanca Statement, however, has taken nearly a decade to catch on at the national level, as countries were still adapting to the implementation of SEN support in general. Therefore, progression towards inclusive education has been delayed until the services were properly implemented. Ultimately, the implementation of the aims of the Salamanca Statement has been lacklustre, while the UDHR and the CRPD have been integrated significantly better. Possible reasons for the diminished implementation of the Salamanca Statement include the variance in education systems and the lack awareness of the benefits of inclusive education to people with SEN. When aligning the outcomes of this paper with the outcomes of the work by Roleska and Roman-Urrestarazu and colleagues [29], it becomes apparent that all countries included thus far in the mapping project have attempted to create an environment of inclusive education. However, in doing so, they try to fuse two systems that differ significantly in scale and regulation. Hence, the feasibility of an EU guideline that addresses the common aspects of mainstream and special education when attempting to implement inclusive education should be looked into.

While mapping relevant policies with regards to SEN internationally and in countries under study, it became apparent that the values and goals of the UDHR and CRPD have been translated into national policy and are being reinforced in the most recent policy initiatives as well. The attempts at implementing inclusive education further is a prime example of this, as it further aims to realise horizontal equity and facilitate access to education and growth for all children. Also, the role of family involvement in the educational trajectory of children with SEN in each country has been reported, which came down to the involvement of parents and guardians. More specifically, there is some guidance on international level on the involvement of parents. Each country under study involves parents in start of the education process by allowing them to choose the school. Additionally, parents with children of SEN in Germany and Flanders actively receive guidance on how to address the SEN of their child at home. Other countries have not implemented such measures for parents.

However, this study did not come without its limitations. Firstly, the scope of the study only included three counties, and therefore, the results cannot be generalised to countries not included in this analysis. It is also difficult to produce clear conclusions on the average level of the fulfilment of the right to education considering the qualitative nature of this work. Secondly, non-governmental organisations were not included in this study, unless their work 
was laid down in legislation in some way, like the Charter for Persons with Autism by Autism-Europe. Finally, the scope of this study only included children with autism. As a result, adults with autism that are still in an educational environment are not included in this analysis, while they may experience learning difficulties all the same.

This study also provides some opportunities for further research. Firstly, mapping the autism SEN policy relevant to adult education would extend the approach to understand how this population group's needs can be met better. Secondly, the prevalence of autism and SEN in children in Germany should be mapped. Thirdly, while an overview of policy is provided in this research, adherence to and implementation of policy was not addressed. Therefore, a survey-based study on adherence to SEN policy in autism may contribute valuable insight to improving policymaking, so barriers can be accounted for moving forward. Fourthly, aside from education, employment is an area that can also be heavily affected by SEN and autism. A policy analysis in the employment sector and how SEN in autism are accounted for in this sector can contribute to the process of improving the employment possibilities of people with autism. Fifthly, the cognitive and social impacts of inclusive education in autism have been extensively investigated. However, it is not reported whether those results are universal for children with autism and SEN or whether that is offset by a degree of learning difficulties among children with autism. This is especially important considering the high proportion of people with autism with intellectual disabilities. Investigating how learning disabilities with autism and inclusive education can aid in tailoring better fitted education for children with SEN. Sixthly, one of the most common problems that inclusive education encounters is that a teacher cannot address the difficulties of a child with SEN, because there are too many other children to address as well. Therefore, a longitudinal evaluation that assesses the outcomes of children with and without SEN in inclusive education when assigned to smaller classes could provide major insight in determining the feasibility of integrating inclusive education in the education system currently in place. Finally, the effects of the General Data Protection Regulation have the potential to significantly complicate collaborations between institutions that deal with SEN data. A proper study to map these difficulties and address solutions should be conducted.

Finally, there are two major policy recommendations that can be extrapolated from these findings. Firstly, the current trend of inclusive education is to systematically introduce children with SEN into mainstream schools without changing the structure of the mainstream 
education. However, the structure of that system is a leading factor in why children with SEN were not able to participate fully. While additional services are made available, it may be more feasible to push incremental changes (e.g. smaller class sizes, individual learning trajectories) to the education system to alleviate stress from teachers, who can then attend to the needs of the children properly, thus increasing the quality of assistance that is advocated for in both international and national policy. Secondly, our findings indicate that some countries still operate under different definitions of SEN. Therefore, we recommend official guidelines on the definition and impacts of groups of SEN to be drafted at an international level. The report by Carroll and colleagues [10] already makes a division between several types of SEN and this could be used as underlying framework. As a result, it could benefit the transferability of SEN policy, since it removes the potential limiting factor of differing terminologies across countries.

\section{Conclusion}

This study provided information on the right to education of people with autism in the Netherlands, Germany, and Belgium. In all three countries, the values of the UDHR on the right to education have been integrated in national legislation. Appropriate SEN services and special schools are in place so that all children can enjoy their right to education. All countries regulated the provision of SEN through schools, except for the German speaking community in Belgium, which implemented a separate department for this. Active parental involvement is included in the legislation of the Netherlands and Flanders, while the other regions involve them through providing education for the SEN of the child and by leaving them the decision which school the child will attend. To this day, research on education and autism policies is limited, both in the EU and globally and is an important gap in autism research.

\section{References}

1. American Psychiatric Association. Diagnostic and statistical manual of mental disorders (5th ed.). Washington, DC; 2013.

2. Lai MC, Lombardo M V, Baron-Cohen S. Autism. Lancet [Internet]. 2013/10/01. 2014;383:896-910. Available from: https://www.sciencedirect.com/science/article/pii/S0140673613615391?via\%3Dihub 3. Loomes R, Hull L, Mandy WPL. What Is the Male-to-Female Ratio in Autism Spectrum Disorder? A Systematic Review and Meta-Analysis. J Am Acad Child Adolesc Psychiatry [Internet]. Elsevier; 2017 [cited 2018 May 29];56:466-74. Available from: 
https://www.sciencedirect.com/science/article/pii/S0890856717301521?via\%3Dihub

4. Knapp M, Romeo R, Beecham J. Economic cost of autism in the UK. Autism [Internet]. 2009;13:317-36. Available from:

http://journals.sagepub.com/doi/pdf/10.1177/1362361309104246

5. Howlin P, Goode S, Hutton J, Rutter M. Adult outcome for children with autism. J Child Psychol Psychiatry [Internet]. 2004;45:212-29. Available from:

http://onlinelibrary.wiley.com/doi/10.1111/j.1469-7610.2004.00215.x/abstract

6. van Heijst BFC, Geurts HM. Quality of life in autism across the lifespan: A meta-analysis. Autism [Internet]. 2015;19:158-67. Available from:

http://journals.sagepub.com/doi/pdf/10.1177/1362361313517053

7. World Health Organisation. Autism spectrum disorders [Internet]. 2017. Available from: http://www.who.int/mediacentre/factsheets/autism-spectrum-disorders/en/

8. European Commission. European Disability Strategy 2010-2020: A Renewed Commitment to a Barrier-Free Europe [Internet]. 2010 p. 1-9. Available from: http://eurlex.europa.eu/LexUriServ/LexUriServ.do?uri=CELEX:52010DC0636:en:NOT\#top

9. Baron-Cohen S. Editorial Perspective: Neurodiversity-a revolutionary concept for autism and psychiatry. J Child Psychol Psychiatry. 2017;58:744-7.

10. Carroll J, Bradley L, Crawford H, Hannant P, Johnson H, Thompson A. SEN support: A rapid evidence assessment. 2017.

11. Grindal T, Hehir T, Freeman B, Lamoreau R, Borquaye Y, Burke S. A Summary of the Research Evidence on Inclusive Education [Internet]. 2016. Available from:

https://www.abtassociates.com/sites/default/files/2019-

03/A_Summary_of_the_evidence_on_inclusive_education.pdf

12. Marder C, Wagner M, Sumi C. The social adjustment of youth with disabilities. Achiev. Youth With Disabil. Dur. Second. Sch. A Rep. From Natl. Longitud. Transit. Study-2 (NLTS2). Menlo Park, CA; 2003.

13. Katz J, Mirenda P. Including students with developmental disabilities in general education classrooms: Educational benefit. Int J Spec Educ [Internet]. 2002 [cited 2018 May 10];17.

Available from:

https://achieve.lausd.net/cms/lib08/CA01000043/Centricity/domain/168/research you can use/Education Benefits of Inclusion for Disabled and Non-Disabled Students.pdf 14. Sumi C, Marder C, Wagner M. The Social Adjustment of Elementary and Middle School Students with Disabilities. 2005 [cited 2018 May 10]; Available from:

https://seels.sri.com/designdocs/engagement/05_SEELS_outcomes_C5_10-3-05.pdf 
15. Baer RM, Daviso AW, Flexer RW, McMahan Queen R, Meindl RS. Students With Intellectual Disabilities. Career Dev Except Individ [Internet]. SAGE PublicationsSage CA: Los Angeles, CA; 2011 [cited 2018 May 13];34:132-41. Available from: http://journals.sagepub.com/doi/10.1177/0885728811399090

16. Wagner M, Blackorby J, Cameto R, Newman L. What Makes a Difference? Influences on Postschool Outcomes of Youth with Disabilities. The Third Comprehensive Report from the National Longitudinal Transition Study of Special Education Students. [Internet]. Menlo Park, CA: SR International; 1993 Dec. Available from: https://eric.ed.gov/?id=ED365085 17. Nederlands Centrum Onderwijs en Jeugdzorg. Feiten \& cijfers: leerlingen met speciale onderwijsbehoeften 2015/'16 [Internet]. 2018. [cited 2018 May 29]. Available from: https://www.ncoj.nl/factsfigures/onderwijs/2016/fc2016_onderwijsbehoeften.php 18. Riddell S. Education and Disability/Special Needs-policies and practices in education, training and employment for students with disabilities and special educational needs in the EU [Internet]. 2012. Available from: www.nesse.fr

19. UNESCO. Policy guidelines on inclusion in education in all. Unesco [Internet]. 2009;136. Available from: http://unesdoc.unesco.org/images/0014/001402/1

20. Roelfsema MT, Hoekstra RA, Allison C, Wheelwright S, Brayne C, Matthews FE, et al. Are autism spectrum conditions more prevalent in an information-technology region? A school-based study of three regions in the Netherlands. J Autism Dev Disord [Internet]. 2012;42:734-9. Available from: https://link.springer.com/content/pdf/10.1007\%2Fs10803011-1302-1.pdf

21. European Agency for Special Needs and Inclusive Education. Country information for Germany - Systems of support and specialist provision | European Agency for Special Needs and Inclusive Education [Internet]. 2018 [cited 2018 Apr 30]. Available from: https://www.european-agency.org/country-information/germany/systems-of-support-andspecialist-provision

22. Wijzigingen aan de Grondwet [Internet]. 1988. p. 2-3. Available from: http://reflex.raadvst-consetat.be/reflex/pdf/Mbbs/1988/07/19/19964.pdf

23. Standing Conference of the Ministers of Education and Cultural Affairs. The Education System in the Federal Republic of Germany 2014/2015 [Internet]. 2017. Available from: https://www.kmk.org/fileadmin/Dateien/pdf/Eurydice/Bildungswesen-englpdfs/support_and_guidance.pdf

24. European Agency for Special Needs and Inclusive Education. Country information for Belgium (Flemish) - Systems of support and specialist provision | European Agency for 
Special Needs and Inclusive Education [Internet]. 2018 [cited 2018 Apr 30]. Available from: https://www.european-agency.org/country-information/belgium-flemish/systems-of-supportand-specialist-provision

25. European Agency for Special Needs and Inclusive Education. Country information for Belgium (French) - Systems of support and specialist provision | European Agency for Special Needs and Inclusive Education [Internet]. 2018 [cited 2018 Apr 30]. Available from: https://www.european-agency.org/country-information/belgium-french/systems-of-supportand-specialist-provision

26. Department for Education. Special educational needs and disability code of practice: 0 to 25 years. 2015 .

27. The Autism Strategy and Action Plan (2013-20) [Internet]. 2013 [cited 2018 May 13]. Available from: https://www.health-ni.gov.uk/sites/default/files/publications/dhssps/autismstrategy-action-plan-2013_0.pdf

28. NIASA. National Autism Plan for Children (NAPC). Natl. Autistic Soc. 2003.

29. Roleska M, Roman-Urrestarazu A, Griffiths S, Czabanowska K, Sherlaw W, Brayne C. Autism and the Right to Education in the EU: Policy Mapping in the United Kingdom, France, Poland and Spain. 2017;

30. EDUCAUS [Internet]. [cited 2019 Jun 19]. Available from: https://www.educaus.eu/ 31. Objectives and Coverage [Internet]. [cited 2019 Jun 19]. Available from: https://www.educaus.eu/objectives-and-coverage.html

32. United Nations. Universal Declaration of Human Rights [Internet]. 1948. Available from: http://www.un.org/en/udhrbook/pdf/udhr_booklet_en_web.pdf

33. United Nations. Convention on the Rights of Persons with Disabilities [Internet]. 2006. Available from:

http://www.ohchr.org/EN/HRBodies/CRPD/Pages/ConventionRightsPersonsWithDisabilities. $\operatorname{aspx} \# 3$

34. Eurostat. Population change - Demographic balance and crude rates at national level [Internet]. 2018 [cited 2018 Apr 30]. Available from:

http://appsso.eurostat.ec.europa.eu/nui/show.do?dataset=demo_gind\&lang=en

35. Belgian Federal Government. A statistical overview of the Belgian population |

Belgium.be. 2016.

36. Germany: States and Major Cities - Population Statistics, Maps, Charts, Weather and Web Information [Internet]. 2016 [cited 2018 Jun 11]. Available from:

http://www.citypopulation.de/Deutschland-Cities.html 
37. Bachmann CJ, Gerste B, Hoffmann F. Diagnoses of autism spectrum disorders in Germany: Time trends in administrative prevalence and diagnostic stability. Autism. 2018;22:283-90.

38. Dereu M, Warreyn P, Raymaekers R, Meirsschaut M, Pattyn G, Schietecatte I, et al. Screening for Autism Spectrum Disorders in Flemish Day-Care Centres with the Checklist for Early Signs of Developmental Disorders. J Autism Dev Disord [Internet]. 2010 [cited 2018 Apr 25];40:1247-58. Available from: http://www.ncbi.nlm.nih.gov/pubmed/20198413 39. Eurostat. National accounts and GDP - Statistics Explained [Internet]. 2017 [cited 2018 May 23]. Available from: http://ec.europa.eu/eurostat/statisticsexplained/index.php?title=National_accounts_and_GDP 40. European Association of Service Providers for Persons with Disabilities. Social welfare systems across Europe [Internet]. 2014. Available from:

http://www.easpd.eu/sites/default/files/sites/default/files/SensAge/d4social_welfare_systems_across_europe.pdf 41. Arksey H, O’Malley L. Scoping studies: towards a methodological framework. Int J Soc Res Methodol [Internet]. Taylor and Francis Group Ltd; 2005 [cited 2018 Apr 25];8:19-32. Available from: http://www.tandfonline.com/doi/abs/10.1080/1364557032000119616 42. Levac D, Colquhoun H, O’Brien KK. Scoping studies: advancing the methodology. Implement Sci [Internet]. 2010 [cited 2018 Apr 25];5:69. Available from: http://www.ncbi.nlm.nih.gov/pubmed/20854677 43. Mahoney J. Path dependence in historical sociology. Theory Soc [Internet]. 2000;29:50748. Available from:

http://webarchiv.ethz.ch/soms/teaching/OppFall09/MahoneyPathDependence.pdf 44. Moher D, Liberati A, Tetzlaff J, Altman DG, PRISMA Group. Preferred reporting items for systematic reviews and meta-analyses: the PRISMA statement. BMJ [Internet]. British Medical Journal Publishing Group; 2009 [cited 2018 May 13];339:b2535. Available from: http://www.ncbi.nlm.nih.gov/pubmed/19622551 45. Pierson P. Increasing Returns, Path Dependence, and the Study of Politics. Am Polit Sci Rev [Internet]. 2000;94:251-67. Available from: http://www.journals.cambridge.org/abstract_S0003055400221059 46. Collier R, Collier D. Shaping the Political Arena Critical Junctures, the Labor Movement, and Regime Dynamics in. 2002 [cited 2018 May 15]; Available from: https://cloudfront.escholarship.org/dist/prd/content/qt8qr1z7gc/qt8qr1z7gc.pdf?t=ok97a8 47. European Agency for Special Needs and Inclusive Education. Country Information 
[Internet]. 2018. Available from: https://www.european-agency.org/country-information 48. European Commission. Eurydice Network [Internet]. 2018. Available from: https://eacea.ec.europa.eu/national-policies/eurydice/home_en 49. United Nations. Declaration on the Rights of the Child [Internet]. 1959. Available from: https://www.unicef.org/malaysia/1959-Declaration-of-the-Rights-of-the-Child.pdf 50. United Nations. Declaration on the Rights of Mentally Retarded Persons [Internet]. 1971. Available from:

http://www.ohchr.org/EN/ProfessionalInterest/Pages/RightsOfMentallyRetardedPersons.aspx 51. United Nations. Declaration on the Rights of Disabled Persons [Internet]. 1975. Available from: http://www.ohchr.org/EN/ProfessionalInterest/Pages/RightsOfDisabledPersons.aspx 52. United Nations. Convention on the Rights of the Child [Internet]. 1989 [cited 2018 May 2]. Available from: http://www.ohchr.org/Documents/ProfessionalInterest/crc.pdf 53. UNESCO. The Salamanca Statement and Framework for Action on Special Needs Education [Internet]. 1994 [cited 2018 May 19]. Available from: http://www.unesco.org/education/pdf/SALAMA_E.PDF

54. Council of Europe. European Convention on Human Rights [Internet]. 1950 [cited 2018 May 1]. Available from: www.echr.coe.int 55. Autism-Europe. Charter for Persons with Autism [Internet]. 1992. Available from: http://www.autismeurope.org/wp-content/uploads/2017/08/charter-for-persons-with-autism1.pdf

56. European Commission. Treaty of Amsterdam amending the Treaty on European Union, the Treaties establishing the European Communities and certain related acts [Internet]. 1997 [cited 2018 May 3]. Available from: http://www.europarl.europa.eu/topics/treaty/pdf/amsten.pdf

57. European Commission. Charter of Fundamental Rights of the European Union [Internet]. 2000. Available from: http://www.europarl.europa.eu/charter/pdf/text_en.pdf 58. European Commission. Treaty on the Functioning of the European Union [Internet]. 2009. Available from: http://eur-lex.europa.eu/legalcontent/EN/TXT/PDF/?uri=CELEX:12012E/TXT

59. European Parliament. Written Declaration on Autism [Internet]. 2015 [cited 2018 May 3]. Available from: http://www.autismeurope.org/wp-content/uploads/2017/08/writtendeclaration-on-autism-to-the-ep.pdf 60. The European Parliament, The European Council. GDPR - General Data Protection Regulation [Internet]. Off. J. Eur. Union. 2016 [cited 2018 May 31]. p. 20-30. Available 
from: https://eur-lex.europa.eu/legal-

content/EN/TXT/?uri=uriserv:OJ.L_.2016.119.01.0001.01.ENG

61. Ministry of Education, Culture and S. Geschiedenis | Ministerie van Onderwijs, Cultuur en Wetenschap | Rijksoverheid.nl [Internet]. [cited 2018 May 16]. Available from:

https://www.rijksoverheid.nl/ministeries/ministerie-van-onderwijs-cultuur-en-

wetenschap/organisatie/geschiedenis

62. Staatsblad van het Koninkrijk der Nederlanden. Wet op de expertisecentra [Internet]. 1982 [cited 2018 May 5]. Available from: http://wetten.overheid.nl/BWBR0003549/2018-02-01

63. Staatsblad van het Koninkrijk der Nederlanden. Wet op het voortgezet onderwijs [Internet]. 1963 [cited 2018 May 5]. Available from:

http://wetten.overheid.nl/BWBR0002399/2018-02-01

64. Staatsblad van het Koninkrijk der Nederlanden. Wet Passend Onderwijs [Internet]. 2012 [cited 2018 May 1]. Available from: https://www.passendonderwijs.nl/wpcontent/uploads/2012/11/Wet-passend-onderwijs.pdf 65. Nederlandse Grondwet - Tiende Hoofdstuk. Van het Onderwijs en het Armbestuur. [Internet]. 1917 [cited 2018 May 21]. Available from:

https://www.denederlandsegrondwet.nl/id/vi7hh3915sze/tiende_hoofdstuk_van_het_onderwij S_en

66. OECD. School choice and school vouchers [Internet]. 2017. Available from: http://www.oecd.org/education/School-choice-and-school-vouchers-an-OECDperspective.pdf

67. Bundesrepublik Deutschland. Grundgesetz für die Bundesrepublik Deutschland [Internet]. 1949 [cited 2018 May 4]. Available from: www.juris.de

68. The Unification Treaty between the FRG and the GDR [Internet]. CVCE.EU by UNI.LU; 1990 [cited 2018 May 7]. Available from:

https://www.cvce.eu/en/obj/the_unification_treaty_between_the_frg_and_the_gdr_berlin_31_ august_1990-en-2c391661-db4e-42e5-84f7-bd86108c0b9c.html

69. Verfassung des Freistaates Bayern [Internet]. 1946 [cited 2018 May 18]. Available from: http://www.dircost.unito.it/cs/docs/bayern1946.htm

70. The constitution of Lower Saxony - Niedersächsischer Landtag [Internet]. 1993 [cited 2018 May 18]. Available from: http://www.landtagniedersachsen.de/the_constitution_of_lower_saxony/

71. REVOSax Landesrecht Sachsen - Sächsische Verfassung [Internet]. 1992 [cited 2018 May 18]. Available from: https://www.revosax.sachsen.de/vorschrift/3975/33328 
72. Bayerisches Gesetz über das Erziehungs- und Unterrichtswesen in der Fassung der Bekanntmachung [Internet]. 2000 [cited 2018 May 18]. Available from: http://www.gesetzebayern.de/Content/Document/BayEUG/true

73. Schulgesetz für das Land Nordrhein-Westfalen [Internet]. 2005 [cited 2018 May 18]. Available from:

https://recht.nrw.de/lmi/owa/br_bes_text?anw_nr=2\&gld_nr=2\&ugl_nr=223\&bes_id=7345\& menu=1\&sg=0\&aufgehoben=N\&keyword=schulgeset $\#$ det 0

74. Landesrecht Sachsen - Sächsisches Schulgesetz [Internet]. 2004 [cited 2018 May 18]. Available from: https://www.revosax.sachsen.de/vorschrift/4192-Saechsisches-Schulgesetz 75. Niedersächsisches Schulgesetz [Internet]. 1998 [cited 2018 May 18]. Available from: http://www.nds-

voris.de/jportal/;jsessionid=5B0EBD84D2CC606349B2AAA1FDB49767.jp15?quelle=jlink\& query $=$ SchulG+ND\&psml=bsvorisprod.psml\&max=true\&aiz=true\#jlr-SchulGNDV45P14 76. Standing Conference of the Ministers of Education and Cultural Affairs. Empfehlung zur Ordnung des Sonderschulwesens. 1972.

77. Bundesministerium des Justiz und für Verbraucherschutz. Sozialgesetzbuch - Achtes Buch (VIII) - Kinder- und Jugendhilfe [Internet]. 1990 [cited 2018 May 7]. Available from: https://www.gesetze-im-internet.de/sgb_8/BJNR111630990.html

78. Standing Conference of the Ministers of Education and Cultural Affairs. Empfehlungen zur sonderpädagogischen Förderung in den Schulen in der Bundesrepublik Deutschland [Internet]. 1994 [cited 2018 May 7]. Available from:

https://www.kmk.org/fileadmin/Dateien/pdf/PresseUndAktuelles/2000/sopae94.pdf

79. Standing Conference of the Ministers of Education and Cultural Affairs. Erziehung und Unterricht von Kindern und Jugendlichen mit autistischem Verhalten [Internet]. 2000 [cited 2018 May 7]. Available from:

https://www.kmk.org/fileadmin/Dateien/veroeffentlichungen_beschluesse/2000/2000_06_16Empfehlung-autistisches-Verhalten.pdf

80. Bundesministerium des Justiz und für Verbraucherschutz. Sozialgesetzbuch Neuntes Buch - Rehabilitation und Teilhabe von Menschen mit Behinderungen [Internet]. 2001 [cited 2018 May 7]. Available from: https://www.gesetze-iminternet.de/sgb_9_2018/BJNR323410016.html

81. Bundesministerium des Justiz und für Verbraucherschutz. Sozialgesetzbuch (SGB) Zwölftes Buch (XII) - Sozialhilfe [Internet]. 2003. Available from: https://www.gesetze-iminternet.de/sgb_12/BJNR302300003.html 
82. Standing Conference of the Ministers of Education and Cultural Affairs. Inklusive Bildung von Kindern und Jugendlichen mit Behinderungen in Schulen [Internet]. 2011 [cited 2018 May 7]. Available from:

https://www.kmk.org/fileadmin/veroeffentlichungen_beschluesse/2011/2011_10_20-

Inklusive-Bildung.pdf

83. Verhoeven JC. Het onderwijssysteem in België - Vlaamse Gemeenschap. Brussels; 2002.

84. Nationaal Congres. De Belgische Grondwet [Internet]. 1994 [cited 2018 May 6].

Available from: https://www.senate.be/doc/const_nl.html

85. Wet tot wijziging van sommige bepalingen van de onderwijswetgeving [Internet]. 1959

[cited 2018 May 19]. Available from: https://data-

onderwijs.vlaanderen.be/edulex/document.aspx?docid=12373

86. Wet op het buitengewoon en geïntegreerd onderwijs [Internet]. 1970 [cited 2018 May 19]. Available from: https://data-onderwijs.vlaanderen.be/edulex/document.aspx?docid=12930

87. Région de Bruxelles-Capitale. Special needs education - Région bruxelloise - Brussels Gewest [Internet]. [cited 2018 May 23]. Available from: http://be.brussels/education-andtraining/special-needs-education?set_language $=$ en

88. Flemish Parliament. Decreet basisonderwijs [Internet]. 1997 [cited 2018 May 6].

Available from: http://data-onderwijs.vlaanderen.be/edulex/document.aspx?docid=12254

89. Flemish Parliament. Decreet houdende een kader voor het Vlaamse gelijkekansen- en gelijkebehandelingsbeleid [Internet]. 2008 [cited 2018 May 6]. Available from:

https://codex.vlaanderen.be/Portals/Codex/documenten/1017082.html

90. Flemish Parliament. Besluit van de Vlaamse Regering houdende de codificatie betreffende het secundair onderwijs [Internet]. 2010 [cited 2018 May 6]. Available from: http://dataonderwijs.vlaanderen.be/edulex/document.aspx?docid=14289

91. Flemish Parliament. Decreet betreffende maatregelen voor leerlingen met specifieke onderwijsbehoeften [Internet]. 2014 [cited 2018 May 6]. Available from:

https://codex.vlaanderen.be/Portals/Codex/documenten/1024474.html

92. Verhoogde participatiekansen voor personen met autisme creëren - strategisch plan [Internet]. 2017 [cited 2018 May 19]. Available from: https://www.vlaanderen.be/fr/nbwanews-message-document/document/09013557801bf9bc

93. Secrétariat général. Décret organisant l'enseignement spécialisé [Internet]. 2004 [cited 2018 May 6]. Available from: http://www.gallilex.cfwb.be/document/pdf/28737_030.pdf 94. Parliament of the French Community. Decreet betreffende de bestrijding van sommige vormen van discriminatie [Internet]. 2008. Available from: 
http://www.ejustice.just.fgov.be/cgi_loi/change_lg.pl?language $=$ nl\&la=N\&cn=2008121248\& table_name=wet

95. Parliament of the French Community. Decreet betreffende de inclusie van personen met een handicap. 2014.

96. Parliament of the French Community. Decreet betreffende het inclusief onderwijs voor sociale promotie. 2016.

97. Parliament of the German Community. Decreet houdende oprichting van een "Dienststelle der Deutschsprachige Gemeinschaft für Personen mit einer Behinderung” [Internet]. 1990 [cited 2018 May 7]. Available from:

http://www.ejustice.just.fgov.be/cgi_loi/arch_a1.pl?N=\&sql=(text+contains $+(\% 27 \% 27)) \& l a n$ guage $=$ nl\&rech $=1 \&$ tri $=\mathrm{dd}+\mathrm{AS}+\mathrm{RANK} \&$ value $=\&$ table_name $=$ wet $\& \mathrm{cn}=1990061933 \& \mathrm{caller}=$ archive \&fromtab=wet\&la $=$ N\&ver_arch $=001$

98. Decreet betreffende de opdrachten toevertrouwd aan de inrichtende machten en aan het schoolpersoneel en houdende algemene pedagogische en organisatorische bepalingen voor het gewoon onderwijs [Internet]. 1998 [cited 2018 May 20]. Available from:

http://www.etaamb.be/nl/decreet-van-31-augustus-1998_n1998033100.html

99. Decreet over het centrum voor onderwijs aan leerlingen met specifieke behoeften ter bevordering van het onderwijs aan leerlingen met specifieke behoeften in de gewone scholen en de scholen voor onderwijs aan leerlingen met specifieke behoeften evenals ter [Internet]. 2009 [cited 2018 May 20]. Available from:

http://www.ejustice.just.fgov.be/eli/decreet/2009/05/11/2009202854/staatsblad 100. Parliament for German Community. Decreet ter bestrijding van bepaalde vormen van discriminatie [Internet]. 2012 [cited 2018 May 7]. Available from: https://www.unia.be/nl/wetgeving-aanbevelingen/wetgeving/dg-decreet-ter-bestrijding-vanbepaalde-vormen-van-discriminatie

101. Decreet tot oprichting van een dienst van de Duitstalige Gemeenschap voor zelfbeschikkend leven [Internet]. 2016. Available from:

http://www.ejustice.just.fgov.be/cgi_loi/change_lg.pl?language $=$ nl\&la $=$ N\&cn $=2016121307 \&$ table_name $=$ wet 


\section{Additional Files}

Additional File 1

Title: An overview of the demographics of the countries under study.

\begin{tabular}{|c|c|c|c|c|c|c|c|c|}
\hline & \multirow{2}{*}{ The Netherlands } & \multicolumn{4}{|c|}{ Germany } & \multicolumn{3}{|c|}{ Belgium } \\
\hline & & $\mathrm{BA}$ & NRW & $\mathrm{S}$ & LS & FL & WA & $\mathrm{GC}$ \\
\hline Population size & $17.1 \mathrm{mln} *$ & $\begin{array}{l}12.9 \\
\text { mln* }\end{array}$ & $\begin{array}{c}17.8 \\
\mathrm{mln} *\end{array}$ & $4 \mathrm{mln} *$ & $\begin{array}{c}7.9 \\
\mathrm{mln} *\end{array}$ & $6.4 \mathrm{mln} *$ & $3.6 \mathrm{mln} *$ & 75.2 thousand* \\
\hline $\begin{array}{c}\text { Autism } \\
\text { prevalence }(\%)\end{array}$ & $0.6-2.3 * *$ & \multicolumn{4}{|c|}{ German total: $0.4^{* *}$} & \multicolumn{3}{|c|}{ Belgian total: $0.6^{* *}$} \\
\hline
\end{tabular}

Description: BA = Bavaria; NRW = North Rhein Westphalia; $\mathrm{S}=$ Saxony; LS = Lower

Saxony; FL = Flanders; WA $=$ Wallonia; $\mathrm{GC}=$ The German Speaking Community in

Belgium. * Dutch population size was found using data from Eurostat [32], the size of the

Länder was reported by the German Statistics Office [34], and the Belgian population size

was reported by the Belgian Federal Government [33]. ** Autism prevalence rates in the

Netherlands were reported by Roelfsema and colleagues [20], in Germany by Bachmann and colleagues [35], and in Belgium by Dereu and colleagues [36].

\section{Additional File 2}

Title: An overview of the countries under study with regards to demographics, autism prevalence, and SEN policy.

\begin{tabular}{|c|c|c|c|c|c|c|c|c|}
\hline & \multirow{2}{*}{ The Netherlands } & \multicolumn{4}{|c|}{ Germany } & \multicolumn{3}{|c|}{ Belgium } \\
\hline & & BA & NRW & $\mathrm{S}$ & LS & FL & WA & $\mathrm{GC}$ \\
\hline Population size & $17.1 \mathrm{~m} \ln *$ & $\begin{array}{l}12.9 \\
\mathrm{~m} \ln *\end{array}$ & $\begin{array}{l}17.8 \\
\mathrm{mln} *\end{array}$ & $4 \mathrm{mln} *$ & $\begin{array}{c}7.9 \\
\mathrm{mln} *\end{array}$ & $6.4 \mathrm{mln} *$ & $3.6 \mathrm{mln} *$ & 75.2 thousand* \\
\hline Autism prevalence (\%) & $0.6-2.3 * *$ & \multicolumn{4}{|c|}{ German total: $0.4^{* *}$} & \multicolumn{3}{|c|}{ Belgian total: $0.6^{* *}$} \\
\hline Type of education & $\begin{array}{l}\text { Mainstream, mixed, } \\
\text { special }\end{array}$ & $\begin{array}{l}\text { Mixed, } \\
\text { special }\end{array}$ & $\begin{array}{l}\text { Mixed, } \\
\text { special }\end{array}$ & $\begin{array}{l}\text { Mainstream, } \\
\text { special }\end{array}$ & $\begin{array}{l}\text { Mixed, } \\
\text { special }\end{array}$ & $\begin{array}{l}\text { Mainstream, mixed, } \\
\text { special }\end{array}$ & $\begin{array}{l}\text { Mainstream, mixed, } \\
\text { special }\end{array}$ & Mainstream, mixed, special \\
\hline $\begin{array}{l}\text { Education funding } \\
\text { scheme }\end{array}$ & $\begin{array}{l}\text { Based on number of } \\
\text { students }\end{array}$ & \multicolumn{4}{|c|}{ Defined in respective Education Act } & \multicolumn{3}{|c|}{ National subsidies for schools in all legislative regions } \\
\hline $\begin{array}{l}\text { Level of education } \\
\text { policy }\end{array}$ & National & \multicolumn{4}{|c|}{ Harmonised nationally } & \multicolumn{3}{|c|}{ Regional } \\
\hline $\begin{array}{l}\text { Family involvement in } \\
\text { education }\end{array}$ & School choice & \multicolumn{4}{|c|}{$\begin{array}{l}\text { School choice, support and social } \\
\text { assistance for parents }\end{array}$} & $\begin{array}{l}\text { School choice, parents } \\
\text { encouraged to engage } \\
\text { in education }\end{array}$ & School choice & School choice \\
\hline Right to education & $\begin{array}{l}\text { Constitution, Education } \\
\text { Acts }\end{array}$ & \multicolumn{4}{|c|}{$\begin{array}{l}\text { The Basic Law, individual Constitutions, } \\
\text { Book Twelve of the Social Code }\end{array}$} & $\begin{array}{l}\text { Belgian Constitution, } \\
\text { School Act, Decree on } \\
\text { Primary Education, } \\
\text { Codex Secondary } \\
\text { Education }\end{array}$ & $\begin{array}{c}\text { Belgian Constitution, } \\
\text { Decree on Primary } \\
\text { Education, Decree on } \\
\text { Combatting Certain } \\
\text { Forms of } \\
\text { Discrimination } \\
\end{array}$ & $\begin{array}{c}\text { Belgian Constitution, } \\
\text { Decree on the Instalment of } \\
\text { a Department o for Persons } \\
\text { with Disabilities, Decree on } \\
\text { Combatting Certain Types } \\
\text { of Discrimination }\end{array}$ \\
\hline Autism policy & Not specified & \multicolumn{4}{|c|}{$\begin{array}{l}\text { Recommendations on the Education of } \\
\text { Children with Autism }\end{array}$} & $\begin{array}{l}\text { Strategic Plan for } \\
\text { Autistic People }\end{array}$ & Not specified & Not specified \\
\hline SEN policy & $\begin{array}{l}\text { Special Education Interim } \\
\text { Act, Appropriate } \\
\text { Education Act }\end{array}$ & \multicolumn{4}{|c|}{$\begin{array}{l}\text { Recommendations on the Organisation } \\
\text { Special Schools, on the Special Needs } \\
\text { Education and its amendments, Decision } \\
\text { on Inclusive Education, Book Eight of the } \\
\text { Social Code, }\end{array}$} & $\begin{array}{l}\text { Decree on Primary } \\
\text { Education, Codex } \\
\text { Secondary Education, } \\
\text { Decree for Scholars } \\
\text { with Special Education } \\
\text { Needs }\end{array}$ & $\begin{array}{l}\text { Decree on Primary } \\
\text { Education, Decree on } \\
\text { the Inclusion of People } \\
\text { with Disability, Decree } \\
\text { on Inclusive Education } \\
\text { for Social Promotion }\end{array}$ & $\begin{array}{l}\text { Decree on Responsibilities } \\
\text { of Education Staff, Decree } \\
\text { on the Establishment of a } \\
\text { Center for Education of } \\
\text { Children with Special } \\
\text { Needs, Decree on the } \\
\text { Instalment of a Department } \\
\text { for Self-Determined Life }\end{array}$ \\
\hline SEN service provision & Schools & \multicolumn{4}{|c|}{ Schools } & Schools & Schools & Independent department \\
\hline
\end{tabular}

Description: $\mathrm{BA}=$ Bavaria; NRW $=$ North Rhein Westphalia; $\mathrm{S}=$ Saxony; $\mathrm{LS}=$ Lower

Saxony; FL = Flanders; WA = Wallonia; $\mathrm{GC}=$ The German Speaking Community in

Belgium. * Dutch population size was found using data from Eurostat [32], the size of the

Länder was reported by the German Statistics Office [34], and the Belgian population size 
was reported by the Belgian Federal Government [33]. ** Autism prevalence rates in the Netherlands were reported by Roelfsema and colleagues [20], in Germany by Bachmann and colleagues [35], and in Belgium by Dereu and colleagues [36].

\section{Additional File 3}

Title: An overview of the specific policies and impacts of the countries under study. 


\begin{tabular}{|c|c|c|c|}
\hline & Year & Policy Name & Brief Description of Implications \\
\hline \multirow{6}{*}{ United Nations } & 1948 & Universal Declaration of Human Rights & Lays down the right to education for every child in the United Nations, including children with SEN. \\
\hline & 1959 & Declaration on the Rights of the Child & Establishes the right for children to receive appropriate treatment that corresponds to their condition. \\
\hline & 1971 & $\begin{array}{l}\text { Declaration on the Rights of Mentally Retarded } \\
\text { Persons }\end{array}$ & $\begin{array}{l}\text { Defines the right for people with developmental, intellectual, and learning conditions to receive appropriate education to } \\
\text { maximise their potential. }\end{array}$ \\
\hline & 1975 & Declaration on the Rights of Disabled Persons & Expands the scope of the 1975 Declaration to include all children with disabilities. \\
\hline & 1989 & Convention on the Rights of the Child & Expands the role of parents in the development of a child with SEN. \\
\hline & 1994 & Salamanca Statement & $\begin{array}{l}\text { Reemphasizes the fundamental right to education for all children, as well as acknowledges that a wide diversity in special } \\
\text { education needs exist and that they should be addressed properly. }\end{array}$ \\
\hline \multirow{8}{*}{ European Unior } & 1952 & European Convention on Human Rights & $\begin{array}{l}\text { A binding version of the Universal Declaration of Human Rights that applies to all European States. Adopted by the Council of } \\
\text { Europe. }\end{array}$ \\
\hline & 1992 & Charter for Persons with Autism & $\begin{array}{l}\text { Emphasises the right to accessible and appropriate education for children with autism. Adopted formally by the European } \\
\text { Parliament in } 1996 \text {. }\end{array}$ \\
\hline & 1997 & Treaty of Amsterdam & Reiterates that discrimination of any kind on the basis of disability is prohibited. \\
\hline & 2000 & $\begin{array}{l}\text { Charter of Fundamental Rights of the European } \\
\text { Union }\end{array}$ & Pooles all previously stated rights and freedoms into a single document that unifies values across the EU. \\
\hline & 2009 & $\begin{array}{l}\text { Treaty on the Functioning of the European } \\
\text { Union }\end{array}$ & Delegates the competence of education completely to the EU Member States. \\
\hline & 2010 & European Disability Strategy 2010-2020 & $\begin{array}{l}\text { Aims to empower people with disabilites, acknowledges that children with SEN are often not included in mainstream education, } \\
\text { calls for inclusion. }\end{array}$ \\
\hline & 2015 & Written Declaration on Autism & Calls for an autism-specific EU strategy with the main focus to better understand autism. \\
\hline & 2018 & General Data Protection Regulation & $\begin{array}{l}\text { Consent is required to access health data, which can complicate the communication between the many parties involved in } \\
\text { addressing health and SEN of a child with autism. }\end{array}$ \\
\hline \multirow{4}{*}{ Netherlands } & 1917 & Dutch Constitution & $\begin{array}{l}\text { Any person can start a school, organise teachings, and determine the ideological, educational, and religious principles on which } \\
\text { the teaching is based. }\end{array}$ \\
\hline & 1982 & Special Education Interim Act & Special education is split from primary education and special education needs are first recognised in the Dutch education system. \\
\hline & 1998 & Amendments to Secondary Education Act & $\begin{array}{l}\text { Secondary education now also covers special education. As a result, all children aged } 4 \text { to } 18 \text { are covered by the Dutch education } \\
\text { system. }\end{array}$ \\
\hline & 2012 & Appropriate Education Act & $\begin{array}{l}\text { Inclusive education is introduced, children with mild special education needs are able to attend mainstream education with } \\
\text { additional assistance. }\end{array}$ \\
\hline \multirow{12}{*}{ Germany } & -1992 & Constitutions of individual Länder & Each consitution either states or refers to the right to education for children in that specific region. \\
\hline & 1949 & The Basic Law & $\begin{array}{l}\text { The responsibility of managing education is put predominantly with the Länder. Lays down the foundation on which a system for } \\
\text { special education can be built. }\end{array}$ \\
\hline & 1972 & $\begin{array}{l}\text { Recommendations on the Organisation of } \\
\text { Special Schools }\end{array}$ & Harmonises the development and organisation of special education across the Länder \\
\hline & 1990 & Unification Treaty & $\begin{array}{l}\text { Laws that previously only applied to the Federal Republic of Germany now also apply to the German Democratic Republic, } \\
\text { unifying Germany back to a single state. }\end{array}$ \\
\hline & 1990 & Book Eight of the Social Code & $\begin{array}{l}\text { Implements youth services to assist parents in the development of the child and to support the child in his or her development and } \\
\text { education. Also establishes a range of support services that can be utilised to provide assistance to children with SEN. }\end{array}$ \\
\hline & 1994 & $\begin{array}{l}\text { Recommendations on Special Needs Education } \\
\text { in the Schools of the Federal Republic of } \\
\text { Germany }\end{array}$ & $\begin{array}{l}\text { Formulates developments to dismantle barriers to education for children with SEN. Promotes equal participation of children with } \\
\text { disabilities in mainstream and special education. }\end{array}$ \\
\hline & \begin{tabular}{r|r|}
$1998-$ \\
2005 \\
\end{tabular} & Education Acts of the individal Länder & $\begin{array}{l}\text { Each Act acknowledges the existence of SEN. Implementation of SEN support can differ per region, varying from inclusion in } \\
\text { mainstream schools to a split between mainstream and special education. }\end{array}$ \\
\hline & 2000 & $\begin{array}{l}\text { Recommendations on the Education of Autistic } \\
\text { Children }\end{array}$ & $\begin{array}{l}\text { Addresses the diagnostic criteria to be used for autism in schools, goals for the education system in general, and the key points for } \\
\text { institutions at every educational level separately. }\end{array}$ \\
\hline & 2001 & Book Nine of the Social Code & Reemphasizes the importance of early medical screening in addressing disabilities as good as possible. \\
\hline & 2003 & Book Twelve of the Social Code & $\begin{array}{l}\text { When addressing special needs at home, the special circumstances in the family of the beneficiaries have to be taken into account } \\
\text { in the case of social assistance benefits. }\end{array}$ \\
\hline & 2008 & $\begin{array}{l}\text { Amendments to the Recommendations on } \\
\text { Special Needs Education in the Schools of the } \\
\text { Federal Republic of Germany }\end{array}$ & Translates the values of the Convention on Rights op Persons with Disabilities to the Länder. \\
\hline & 2011 & $\begin{array}{l}\text { Decision on Inclusive Education of Children and } \\
\text { Young People with Disabilities in schools }\end{array}$ & Introduces inclusion in the education system of Germany and develops standards in special education services. \\
\hline \multirow{5}{*}{ Belgium } & 1831 & Belgian Constitution & Establishes the right to education for children. \\
\hline & 1958 & School Pact & Creates a division between state-led schools and schools led by non-governmental organisations. \\
\hline & 1959 & School Act & Lays down the foundation of primary and secondary education in all of Belgium. \\
\hline & 1970 & Act on Special and Inclusive Education & $\begin{array}{l}\text { Lays down the conditions under which children would be eligible to attend special schools, as well as the organisation of various } \\
\text { levels of education. }\end{array}$ \\
\hline & 1988 & Constitutional Amendments & $\begin{array}{l}\text { Education is delegated to the federal states of Flanders, Wallonia, the German-Speaking Community, and the Brussels-Capital } \\
\text { Region. The Brussels-Capital Region adopts policies from Flanders or Wallonia based on the core language of the school. }\end{array}$ \\
\hline \multirow{5}{*}{ Flanders } & 1997 & Decree on Primary Education & $\begin{array}{l}\text { Mainstream education effectively becomes responsible for the education of all children between ages } 6 \text { and 12. Children only join } \\
\text { special education when the mainstream schools cannot guarantee the development of the child. }\end{array}$ \\
\hline & 2008 & Decree on Equality & Translates the values of the Convention on Rights op Persons with Disabilities to Flanders \\
\hline & 2010 & Codex on Secondary Education & Additional support is required to be made available for children with SEN in secondary education. \\
\hline & 2014 & $\begin{array}{l}\text { Decree for Scholars with Special Education } \\
\text { Needs }\end{array}$ & Primary and secondary education are changed incrementally to now facilitate the inclusion of children with SEN. \\
\hline & 2017 & Strategic Plan for Autistic People & Aims to create and increase opportunities of participation for people with autism. \\
\hline \multirow{4}{*}{ Wallonia } & 2004 & Decree on Primary Education & Implements and regulates special primary and secondary education for children with SEN. \\
\hline & 2008 & $\begin{array}{l}\text { Decree on Combatting Certain Forms of } \\
\text { Discrimination }\end{array}$ & Translates the values of the Convention on Rights op Persons with Disabilities to Wallonia. \\
\hline & 2014 & Decree on the Inclusion of People with Disability & Explains responsibilities of support services towards children with disabilities in educational and extracurricular settings. \\
\hline & 2016 & $\begin{array}{l}\text { Decree on Inclusive Education for Social } \\
\text { Promotion }\end{array}$ & Provides measures that aim to include more children with SEN in mainstream education. \\
\hline \multirow{5}{*}{$\begin{array}{l}\text { German- } \\
\text { speaking } \\
\text { Community }\end{array}$} & 1990 & $\begin{array}{l}\text { Decree on the Instalment of a Department of the } \\
\text { German-Speaking Community for Persons with } \\
\text { Disabilities }\end{array}$ & $\begin{array}{l}\text { Establishes a social service for people with disabilities, which offers offer early support for children with disabilities and their } \\
\text { families, along with supporting the uptake in social systems, like the education system. }\end{array}$ \\
\hline & 1998 & $\begin{array}{l}\text { Decree on the Responsibilities of Staff in } \\
\text { Mainstream and Special Education }\end{array}$ & $\begin{array}{l}\text { Explains that special needs support may need to be provided through a collaboration of multiple institutions in order to achieve } \\
\text { the necessary quality to aid the child. }\end{array}$ \\
\hline & 2009 & $\begin{array}{l}\text { Decree on the Establishment of a Center for } \\
\text { Education of Children with Special Needs in } \\
\text { order to Improve Education for Children with } \\
\text { Special Needs }\end{array}$ & $\begin{array}{l}\text { Establishes the Center for Education for Children with Special Needs, which is responsible for the provision of support to children } \\
\text { with SEN in primary and secondary education, as well as to provide assistance to mainstream schools in order to improve the } \\
\text { quality and inclusivity of education for children with SEN. It also provides a clear definition of children with SEN. }\end{array}$ \\
\hline & 2012 & $\begin{array}{l}\text { Decree on Combatting Certain Types of } \\
\text { Discrimination }\end{array}$ & Translates the values of the Convention on Rights op Persons with Disabilities to the German-speaking Community. \\
\hline & 2016 & $\begin{array}{l}\text { Decree on the Instalment of a Department of the } \\
\text { German-Speaking Community for Self- } \\
\text { Determined Life }\end{array}$ & $\begin{array}{l}\text { Replaces the department established in 1990. This new iteration has a vastly increased scope. It focuses on public awareness, } \\
\text { research, and providing guidance and support for children with SEN. }\end{array}$ \\
\hline
\end{tabular}

Description: This overview provides a comprehensive version of the results section. 


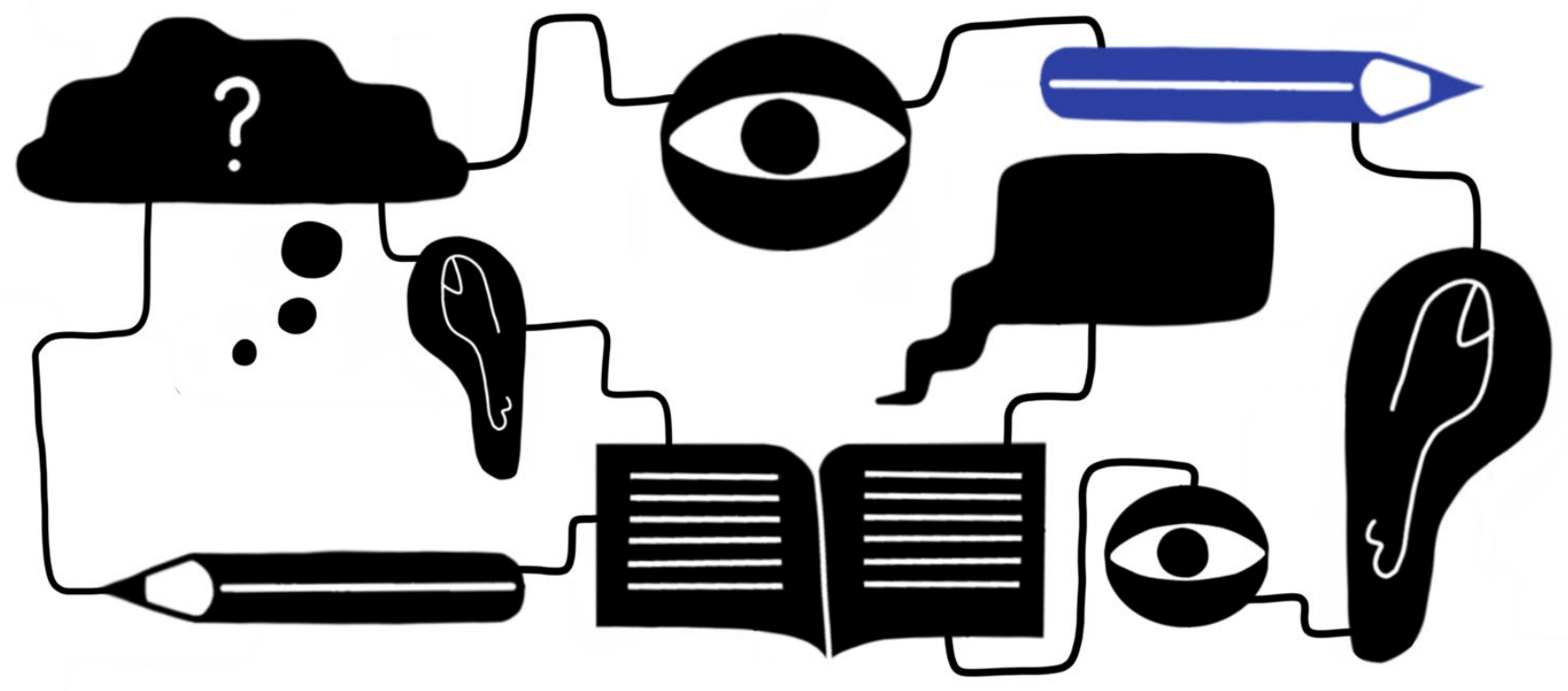

\section{Chapter Two}

Inclusion in Autism and Education Policy

\section{Published as:}

van Kessel, R., Walsh, S., Ruigrok, A.N.V., Holt, R., Yliherva, A., Kärnä, E., Moilanen, I., Hjörne, E., Johansson, S.T., Schendel, D., Pedersen, L., Jørgensen, M., Brayne, C., BaronCohen, S., \& Roman-Urrestarazu, A. (2019). Autism and the right to education in the EU: policy mapping and scoping review of Nordic countries Denmark, Finland, and Sweden. Molecular Autism, 10(1). DOI:10.1186/s13229-019-0290-4 [IF(2019): 5,712] 


\begin{abstract}
Introduction: The universal right to education for people with disabilities has been highlighted by the Universal Declaration on Human Rights and the Convention on the Rights of Persons with Disabilities. In this paper, we mapped policies addressing the right to education and special education needs of autistic children in Denmark, Sweden, and Finland. Methods: A policy path analysis was carried out using a scoping review as an underlying framework for data gathering. Policy mapping was performed independently by both lead authors to increase reliability.

Results and Discussion: The values of the Universal Declaration of Human Rights and the Convention on the Rights of Persons with Disabilities have been closely translated into the respective education systems of the countries under study, offering special education needs services and support in mainstream education with the aim of including as many children into mainstream education as possible. Even though the education systems are comparable, the approaches between the countries under study are slightly different. Denmark and Sweden have passed several policies specifically geared towards special education needs, while Finland incorporates this more in general education policy.

Conclusion: All countries under study have incorporated the values of the Universal Declaration of Human Rights and the Convention on the Rights of Persons with Disabilities in their respective education systems, while emphasising the need to include as many children in the mainstream system as possible.
\end{abstract}




\section{Introduction}

Autism Spectrum Conditions (ASCs, henceforth referred to as autism) are a set of neurodevelopmental conditions characterised by difficulties in communication, social interaction, and unusually narrow interests and/or repetitive behavioural patterns, starting in early childhood and continuing throughout life [1,2]. The global prevalence of autism is estimated to be 1 percent of the population based on a review of prevalence studies across the world [3] with a male-to-female ratio between 3:1 and 4:1 [3,4]. Autism is associated with adverse educational and employment outcomes, and many have significant health needs $[3,5,6]$.

Early identification of autism and subsequent personalised help if needed in early life have been shown to benefit autistic people by improving language development, as well as behavioural and cognitive skills [7]. A key part of these therapies lies with the approach taken towards the child's educational and developmental needs. The evidence base for special educational needs (SEN) support has been reported previously [8]. It was identified that support in the areas of cognition and learning, social, emotional and mental health, and communication and interaction can lead to significant benefits for the development of children with SEN, while also acknowledging that the SEN for autistic children may differ significantly per person.

Grindal and colleagues [9] describe four overarching educational approaches that schools can adopt: a) exclusion, which indicates an environment where children are denied access to education in any way; b) segregation, which happens when children with SEN are being educated in a separated environment; c) integration, which describes the environment where children with SEN are included in mainstream education, yet have to completely adapt to its standardised requirements; and d) inclusion (also known as inclusive education), which entails going beyond simply integrating children with SEN into mainstream education, to a process of systemic educational reform with a vision of providing equitable learning experiences for all children. They find that inclusive education conveys "clear and consistent evidence [of] substantial short- and long-term benefits for children with and without disabilities" [10]. When looking at the children with disabilities specifically, they reported improved social and cognitive development, along with better integration into post-secondary education or employment. 
The evidence base for the importance of equal and inclusive education for autistic children has steadily been reflected in the production of global, and more specifically European-wide, educational policies supporting the rights of autistic children in education. The crucial policy that protects and promotes the rights of autistic children was produced by the United Nations in the Universal Declaration of Human Rights (UDHR) [11], which states that everyone has a fundamental human right to an education "directed to the full development of the human personality". After its ratification, it became the foundation of human rights policy, strategies, and actions in decades to come. It was followed up by the Convention on the Rights of Persons with Disabilities (CRPD) [12] which declares that "persons with disabilities can access an inclusive, quality, and free primary and secondary education on an equal basis with others in the communities in which they live".

Even though the rights of people with disabilities had already been declared in the UDHR, the CRPD produced clear guidelines and rules that adopters had to adhere to. Consequently, it had significant impact in both international strategies and national policies that sought to address the conditions for people with disabilities. Whilst the CRPD has been signed by all Member States of the European Union (EU), the competence needed to implement the values covering the educational rights of autistic people lie exclusively with the individual EU Member States. This is the result of the ratification of the Treaty on the Functioning of the European Union [13], which delegated the competence to regulate the education system (thus also the inclusion of children with SEN in that system) completely to the EU Member States.

Here, we will map the autism and SEN policies aimed at children under the age of 18 in the Nordic countries, namely: Denmark (5.7 million people), Sweden (10.1 million people), and Finland (5.5 million people) [14]. We aim to investigate how these Nordic EU countries approached the implementation of an education policy that promotes the rights of an autistic child to a fair and inclusive education. We will examine this by mapping SEN and disability policies in the context of key policy documents such as the UDHR and CRPD. Furthermore, this paper aims to specifically investigate how and to what extent the concept of inclusive education is implemented in national legislation. Inclusive education can have significant benefits for autistic children $[8,10]$ and the need for inclusive education to be introduced and developed in the national education systems has been endorsed at the international level as well in the Salamanca Statement [15] and more specifically in the CRPD [12]. Finally, an 
overview of the educational structure of the three countries under study is included in an additional file [see Additional File 1].

This work is part of a larger project of the European Consortium for Autism Researchers in Education (EDUCAUS) with an overarching aim of a systematic comparison of policy across all EU countries against the vision of an education system which supports autistic children to fulfil their potential. Like the previous work by EDUCAUS [16,17], this was done by investigating how the values set out in UN documents like the UDHR and CRPD were translated into national education policy over time. We chose to focus on the abovementioned countries because of their shared geographical and cultural characteristics, as well as similar policy values, which should make for an equal comparison between the countries.

Furthermore, these three countries account for $4.2 \%$ of the total EU population (512.6 million people) [14] influenced by autism and SEN policies.

\section{Methods}

Previous work by Roleska and Roman-Urrestarazu and van Kessel and Roman-Urrestarazu established the theoretical framework and validated the methodology that we used in this policy mapping exercise $[17,18]$. The scoping review methodology allows for swift mapping of the key concepts underpinning a wide research area. This methodology is especially suitable for investigating complex matters that have not been comprehensively reviewed $[19,20]$. Additionally, this scoping review and mapping project were performed through the means of a policy path dependence analysis [21]. This methodology is particularly useful for investigating the development of policy based on preceding legislation (such as the UDHR and CRPD) combined with conditional factors [21]. It also amalgamates competing ideas and values, which allows for the examination of interactions among different countries as well as how they follow supranational guidance (e.g. United Nations or EU guidance).

Because there is no single, representative data source in the EU with regards to autism and SEN policy, we adopted a qualitative modular approach to legislative and policy work across the different educational policy layers of analysis (Danish, Swedish, and Finnish specific). This approach divided the searches into two categories: (1) legislation and policy, and (2) scientific literature. Both categories were independently searched in duplication by two of the main authors. By independently executing the search strategy and comparing results afterwards, replicability could be warranted, thus increasing the reliability of the work [22]. 
After the searches were completed, the results were compared and synthesised into a single dataset, from which further analysis was derived. We used the PRISMA framework to report our findings [23].

\subsection{Theoretical Framework for Data Analysis and Path Dependency}

An analysis of policy path interdependency was carried out drawing on past and current international, EU, and national policies in the field of SEN and autism from 1948 up to date as part of the EDUCAUS project. Path dependence approaches allow the identification of policymaking patterns and establish influences and interrelations among policies in linear layers of temporality [24]. It also enables policy process-tracing, which (1) aims to explain what factors are present in critical policy junctures, (2) aims to create a reference framework and depict how decision processes come to conclusions, and (3) aims to describe how behaviour that takes place in different stakeholders as a response to external factors (e.g. a change in the policy environment) affects different institutional arrangements [25,26]. In this case, the UDHR is taken as the starting point, a milestone document that influenced the creation and the content of EU and national policies. We used a timeline to show connection and overlap between policies to enable further analysis. This enabled the interpretation of policy creation as historical sequences and patterns and allowed for the identification of path dependence [24]. Current disability, inclusion, and autism policies are a result of previous events that were tracked with the use of this framework. All policies were analysed by identifying their input in the field of education, advantages and disadvantages, and their relation to other policies.

\subsection{Eligibility Criteria}

In order to remain consistent with the work previously done by EDUCAUS [17,18], the eligibility criteria displayed in Table 1 were used during the data collection of this study. 
Table 1. A summary of the eligibility criteria.

\begin{tabular}{ll}
\hline Inclusion Criteria & Exclusion Criteria \\
\hline - Scope related to the right to education, the & - Policies by non-governmental \\
national education systems, disability laws, & organisations. \\
inclusion, and special education needs; & \\
- Aimed at those under 18 years of age; & \\
- Documents drafted by a governmental & \\
institution; \\
- Publication date after 1948.
\end{tabular}

\subsection{Data Collection and Search Strategy}

The first step in this policy mapping was to review and extract relevant policies and legislation that address the right to education of autistic people directly from original governmental sources. Several databases were used in the collection of data. The national Danish policy website (https://www.retsinformation.dk), Swedish policy repositories (https://beta.lagrummet.se/ and https://www.government.se/), and the Finnish policy repository (FinLex; https://www.finlex.fi/en/) were used for the retrieval of Danish, Swedish, and Finnish policy documents respectively. Additionally, the EU database for national policy (N-Lex; http://eur-lex.europa.eu/n-lex/) was also used to search for the national governmental documents. No limit was put on language and no time limit was used during the searches, as the goal was to create a timeline of policy development, implementation and interaction. As a result, these search criteria allowed our search strategy to find relevant constitutions that date prior to 1948 as well. In order to adequately gauge the impact that the UDHR and subsequent policy have had on national policy, it was important to include these national constitutions as reference points.

The second step was to develop a multi-layered search strategy for electronic databases (PubMed and Google Scholar). A selection of key terms was created to use as the foundation of the search terms: "autism; disability; SEN; education; law; policy; right to education; special needs; special education; inclusive education". Next, the academic databases PubMed and Google Scholar were searched using the following combinations of search terms: "autism \& disability"; "autism \& SEN"; "autism \& education"; "autism \& law”; "autism \& policy”; "SEN \& disability"; "SEN \& law"; "SEN \& policy”; "disability \& law"; "disability \& 
policy". The final search query is shown in Table 2, along with its constituent terms. The national policy depositories were searched using the separate key terms, as combining the search terms yielded little results. The third step consisted of merging policy and academic publications according to the eligibility criteria.

The fourth step was to acquire further information through searching reference lists of key articles (e.g. scientific articles, policy documents, governmental documents) and grey literature. Policy documents and governmental strategies in the countries under study were compared to the already mapped EU disability and educational policy. In case documents were not present, general disability policies and legislation were analysed. The data collection was built on the appraisal of three searches: one for every country under study. The final step was to merge the three searches into one single data repository for the purpose of this scoping review and to compare it to the already mapped policy of the United Nations and the EU for further analysis.

Table 2. The build-up of the final search query for academic databases.

\begin{tabular}{ll}
\hline & Search Query \\
\hline Term 1 & $((((((((($ autism \& law) OR autism \& policy) OR autism \& SEN) OR autism \\
& \& education) OR autism \& disability) OR SEN \& policy) OR SEN \& law) \\
& OR disability \& law) OR disability \& policy) $)$ \\
\hline Term 2 & $(($ Denmark OR Sweden OR Finland $))$ \\
\hline Final Query & $((((((((($ autism \& law) OR autism \& policy) OR autism \& SEN) OR autism \\
& $\&$ education) OR autism \& disability) OR SEN \& policy) OR SEN \& law) \\
& OR disability \& law) OR disability \& policy)) AND ((Denmark OR Sweden \\
& OR Finland))
\end{tabular}

\subsection{Data Analysis}

\subsubsection{Inter-rater Reliability}

Since the data collection of this paper is performed in duplication by the two main authors, it is crucial to determine inter-rater reliability. This was done by determining Cohen's Kappa for each country under study separately. The analysis was performed using R [27], particularly using the 'psych' package [28]. 


\subsubsection{Determination of Path Dependency}

After the search strategy was completed, the gathered data was compared to the data that was already gathered on UN and EU policy in the previous work of EDUCAUS [17,18]. As a result, the extent to which the values of international policies are integrated in the national policies could be established. An overview of international policies and their respective values is provided in an additional file [see Additional File 2].

\section{Results}

We identified 1888 sources (437 for Denmark, 1032 for Sweden, 419 for Finland) through database searching and 6 through other sources. No duplicates were identified; therefore 1894 sources were analysed against the eligibility criteria. After reviewing abstracts, 77 sources were considered eligible for full-text screening. Examples of excluded items included a legislative piece on how education for adults with SEN is regulated, a regulation on addressing deaf-blind and visually impaired children specifically, and legislation that only applied to children with SEN outside the educational institution. Even though these items matched the search criteria, they fall outside the scope of this report. The full-text screening concluded in the further exclusion of 29 articles, with difference in scope, lack of relevance, and unavailability of the full text being the most common factors. The remaining 48 articles (43 policy documents and 5 scientific sources) were included in this review. Also, the Danish policy repository only included policy post-1985. Therefore, we used a non-scientific database (Google) to search for documents that reported on Danish education policy pre1985. In doing so, we identified 1 report by the Danish Ministry of Education that is considered grey literature, which is represented in the 6 sources mentioned above. A PRISMA flowchart illustrates the entire process in Figure 1. Additionally, since the search was independently conducted by the two main authors, Cohen's Kappa was used to ensure inter-reliability [29] in the database searches. This was done by appraising the searches and outcomes of each country under study separately. The results of this analysis are shown in Table 3. In order to account for the lower outcomes for Sweden and Finland, country experts were involved to ensure the completeness and correctness of the policy analysis. 


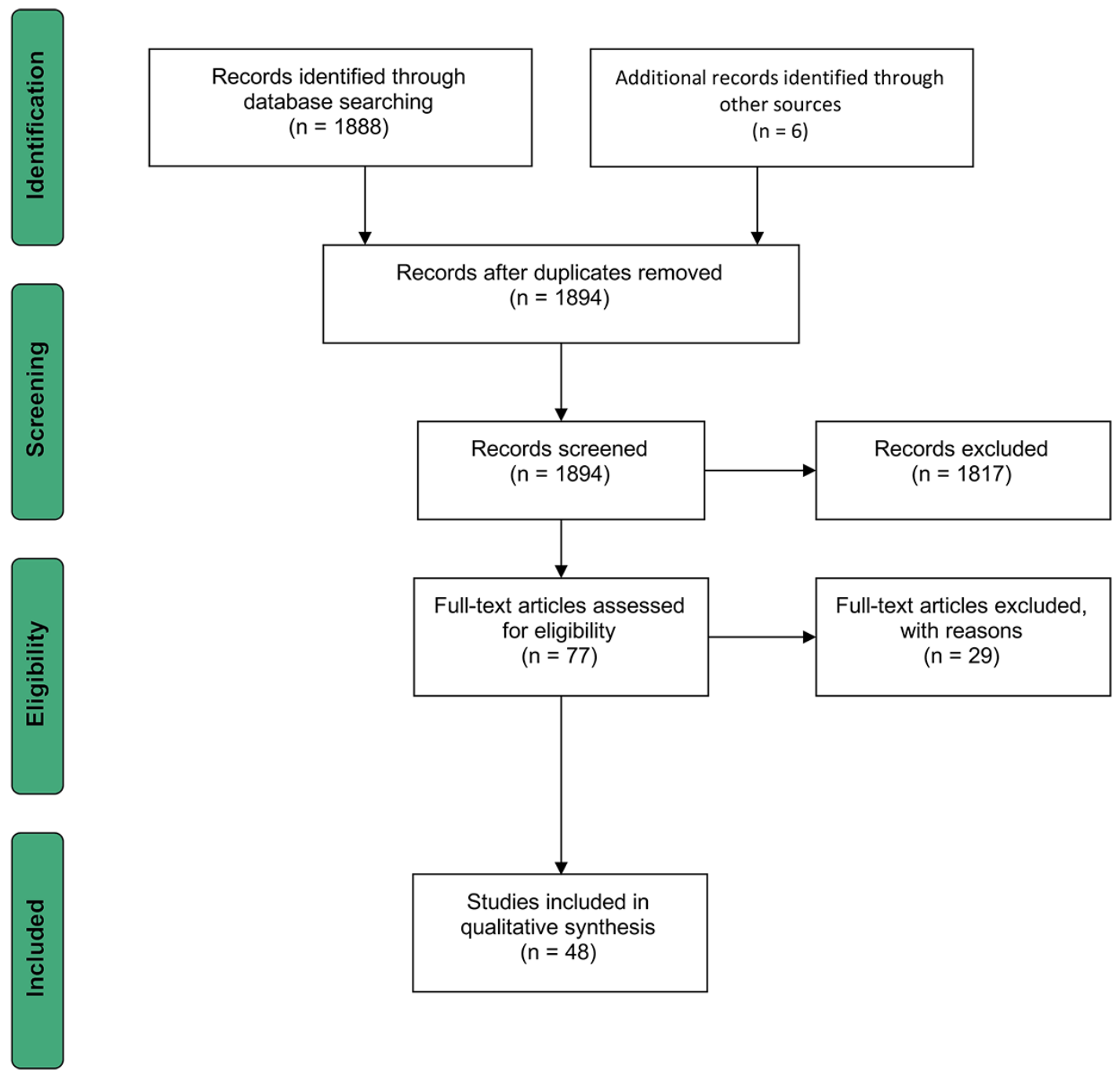

Figure 1. An overview of the data collection process using a PRISMA flowchart. 


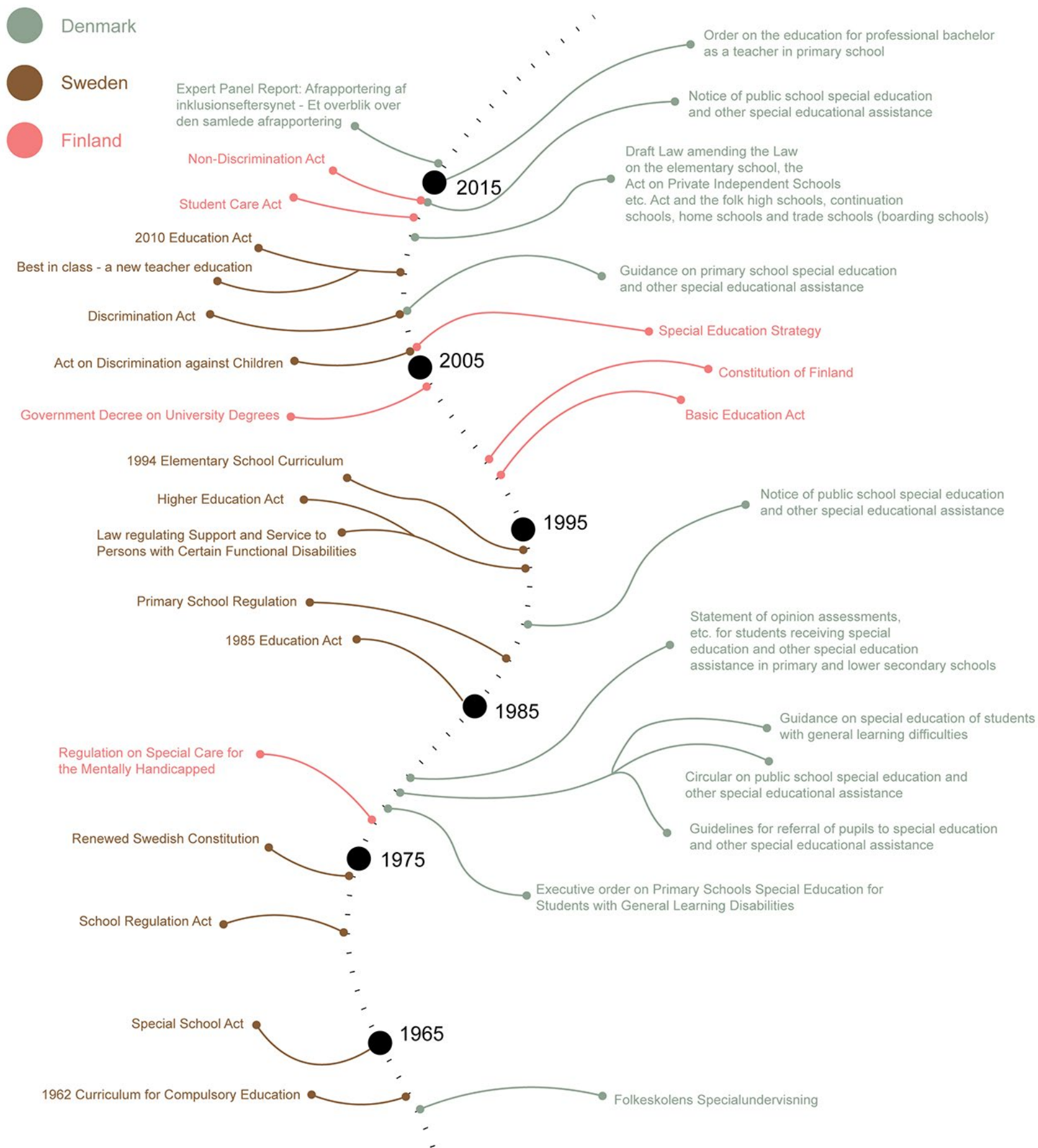

Figure 2. A chronological overview of Danish, Swedish, and Finnish policies with regards to SEN and autism. 
Table 3. An analysis of inter-reliability of the policy database searches using Cohen's Kappa.

\begin{tabular}{lllll}
\hline & & Denmark & Sweden & Finland \\
\hline Investigator 1 & Eligible & 33 & 25 & 13 \\
\cline { 2 - 5 } & Not eligible & 404 & 1007 & 406 \\
\hline Investigator 2 & Eligible & 38 & 27 & 20 \\
\cline { 2 - 5 } & Not eligible & 399 & 1005 & 399 \\
\hline Total included & & 25 & 12 & 6 \\
\hline Total excluded & & 412 & 1020 & 413 \\
\hline Cohen's Kappa & & 0.81 & 0.51 & 0.39 \\
\hline
\end{tabular}

\subsection{Denmark}

Denmark has adopted numerous policies that have shaped their education system to incorporate and include children with SEN. A full summary with descriptions of policies is included in an additional file [see Additional File 4].

The development of the Danish education system for SEN can be divided into two parts, based on the policies included. On one hand, documents up until 1979 had a general theme of establishing a definition for SEN and clarifying that children with SEN should be identified as early as possible in order to be able address their conditions as adequately as possible. More specifically, the Constitution [30] specified the access to education for children with SEN and 'Folkenskolens Specialundervisning' [31] recognised that children with SEN have particular needs that need to be addressed. Subsequently, the Executive Order on Primary Schools Special Education for Students with General Learning Disabilities [32] set out a number of options for the educational environment for these children ranging from: having all teaching take place within a mainstream classroom but with additional support (i.e. an inclusive approach); to being educated partly within mainstream classrooms and partly within the special needs classroom (i.e. an integrative approach); and finally, to being solely educated separately from their peers, which could take place either within mainstream or special schools (i.e. a segregate approach). The accompanying Circular on public school special education and other special educational assistance [33] further developed these options by prescribing class sizes for SEN education and enabling the extension of mandatory education when necessary. 
On the other hand, documents from 1980 onward generally had the theme of shaping the education system to better include the children with SEN, so that they are not isolated in special education, away from their typical peers. The first step towards this was making sure that the progress of children with SEN was able to be measured without being compared to their typical peers. In the Statement of opinion assessments, etc. for students receiving special education and other special education assistance in primary and lower secondary schools, it is explained that, for children with SEN, a separate declaration can be made available that is indicative of them achieving their progress in a certain topic [34]. Next, all existing legislation on SEN education was unified into a single document: The Special Education and Other Special Assistance in Folkeskolen [35]. It 're-humanised' the children with SEN, as it specifically emphasised that the needs of a child should be focused on, rather than the diagnosis, and that children with SEN should no longer be viewed in categories. It also stressed the role of the pedagogical-psychological service (PPR) in deciding if a student needs special education or other special assistance. The two last policies in this theme both aimed at fostering a more inclusive environment, moving away from segregation as much as possible. The measures set out in the Guidance on primary school special education and other special educational assistance [36] encapsulate the essence of truly inclusive education of children with SEN. It is not just simply legislating for the presence of children with SEN into mainstream education, but also a change across the whole culture and organisation of the school that embraces the whole worth of the child for the benefit of that child, their peers, and the school. Finally, the Folkeskole Law amending the Law on the elementary school, the Act on Private Independent Schools etc. Act and the folk high schools, continuation schools, home schools and trade schools (boarding schools) recognised the increase of children in special education [37]. Its aim was to reduce the number of children admitted to special education and the provisions set out to achieve that were (1) redefining when a child would be considered a child with SEN; and (2) giving the municipality and school's director a more decisive role in judging when a child is to be placed in special education.

One notable detail about access to free education is that it has been a legal right of all children in Denmark as far back as 1814 and compulsory since 1855 [38]. In 1814, education access covered only 7 years of education (from age 6-7 years to 14 years), however, the coverage has been extended through the course of the $20^{\text {th }}$ Century to apply to children from age 5-6 years until the age of 16 years [39]. This right was later re-affirmed in the Danish Constitution of 1953 [30]. 
It is mentioned above that the Special Education and Other Special Assistance in Folkeskolen unified previous legislation on SEN education. These prior documents were the first available legal documents to recognise the specific requirements of children with specific conditions. It started with a report on special education from a commission under the Danish Ministry of Education concerning students with intellectual disabilities and students with reading-, speech-, visual- or hearing problems [31]. This report was followed up with specific circulars [40-49] concerning the education of students not able to attend the regular school due to behavioural and psychological conditions (1972), dyslexia (1974), deaf and hearingimpaired, blindness and disability involving vision, physical handicap, language and speech problems (all in 1979).

Grants for SEN are available in Denmark for additional teaching hours and materials to support the pupils, practical assistance to aid assimilation into school life more broadly, and for counselling support for parents and teachers [50]. Referral to regional authorities is generally done by the school, although this process can be triggered by the parents or healthcare staff. Where necessary, assistance in determining the individual needs of the child are available from a national knowledge and advisory service. Provision is also laid out for children whose needs would be best served in a school outside of their locality, with a funding arrangement between the municipality where they are resident and that of the school.

Given responsibilities of the primary school teachers to address SEN in class, the education for teachers was examined as well. The Order on the education for professional bachelor as a teacher in primary school gives a complete overview on the competences that a primary school teacher should be proficient in [51]. From these competences, three focus on or involve the education of children with SEN, which are respectively called 'student learning and development', 'general teaching competence', and 'special education'. Whereas the first two tracks involve the general ability of a teacher to recognise and act upon the behaviour, capabilities, and environment of a child, the special education track sets out specific details for teachers to learn in order to best address SEN in their classroom environment (e.g. reasoned planning and executing an adapted teaching strategy).

Despite progress, and although the Danish Parliament argued for the 2012 "inclusion-law" [37] in light of the Salamanca Statement [15], the 'inclusion law' was also motivated by economic considerations. While the changes in SEN policy in Denmark over the years have 
been for the most part motivated by new insight into the needs of SEN students, this weakened in the wake of the 2008 financial crisis and the coinciding public sector reform in Denmark that shifted all of the economic costs of SEN services solely to the local municipality. The Executive Orders and Guidance documents in 2012 -2014 accompanying the Folkeskole law [52-54] that dropped the crucial provision that a decision on a student's need for special education service and assistance should never be based on economic resources, placed the over-all decision-making power with the school principal (on behalf of the municipal authorities) and reduced the role of the PPR, parents and teacher in the decision process must also be viewed in an economic light apart from educational and didactic considerations.

The 2012 'inclusion law' sparked a strong, and ongoing, public debate on its effects, in response to which the government appointed an expert panel to characterize the student population affected by the transition to inclusion, identify key problems and make recommendations for practical implementation of inclusion. In the expert report published in 2016 [55], the panel's overall impression was that inclusion had inaugurated positive trends in students' overall welfare but substantial challenges remained to be met. The report further detailed 8 major challenge areas and many associated recommendations around strengthening inclusive learning environments; focusing on students' needs in learning and well-being and engaging students; better prioritization of efforts and resources at all levels; strengthening proactive rather than reactive measures; improving access to professional knowledge and help such as PPR; strengthening competencies of teaching staff in working with children with special needs; and strengthening parental involvement and responsibility.

Although these recent events illustrate the potential for SEN policy setbacks in real time, in the larger picture, Denmark has made significant steps in moving from a segregated approach to educating children with SEN towards a more inclusive approach. Free education for all children has always been implemented in the Danish system; a clear definition of SEN was established early on, as well as the right that these children should receive an education like other children; and school systems and teacher education were changed incrementally over time to better support children with SEN. 


\subsection{Sweden}

Sweden has adopted several elaborate policies in order to form its education system to its current state. An overview of all included policies with their descriptions has been added in an additional file [see Additional File 5].

Compulsory education in Sweden was already implemented before the implementation of the UDHR in 1948. The universal Elementary school was introduced as far back as 1842 and six years of schooling was made compulsory for all children in 1882 [56]. This implied that pupils from all social strata entered the school, including children with special education needs and/or developmental disabilities, although they were offered only minimum courses (i.e. a very short period of schooling). The first step in developing the Swedish education system after the ratification of the UDHR by the UN was to clearly establish the rights of children with SEN. This was done firstly by the 1962 Curriculum for Compulsory Education $[57,58]$, which tasked schools to actively contribute in the development of their children into independent, individual, and harmonious adults as much as possible. Additionally, it stressed the need for children with SEN to attend special classes and established eight of these for children with disabilities to attend. The Special School Act [59] subsequently specified developmental delay as a condition that required SEN services to be distributed to. The Swedish Constitution [60] solidified the right to free and accessible education for all children covered by compulsory education and put the institutions in charge of taking care of the children during their stay.

The first mention of an integrative or inclusive school system came right before the implementation of the Swedish Constitution in the School Regulation Act [61], which also addressed the roles of the teachers and specialised equipment in attending to the SEN of children. This was later elaborated by the 1985 Education Act [62], which also laid down the foundation for the current education system. The Act itself covers a lot of different aspects of the education system, most notably (1) right and access to education; (2) the option of special education only for children unable to attend mainstream education due to the severity of their condition; (3) provisions specifically for developmentally delayed children; and (4) the notion that children with autism specifically are included in the scope of legislation that focuses on children with intellectual/learning conditions. Additionally, the Education Act regulated funding for primary, secondary, and special education. It states that the municipalities are the principles of the public schools in their respective areas. This also 
implies that the financing of these institutions is regulated through governmental pathways. With regards to the provision of SEN support, it also explains that there is funding available for municipalities to use, as well as that the municipalities have the right to be reimbursed by the state for their expenditures on SEN support. The Primary School Regulation [63], which closely followed the 1985 Education Act, further elaborated on SEN, SEN services, and special education. It laid out that additional support needs to be provided for children that have difficulties at school and should ideally be given in the regular environment that the child would belong in, though it also acknowledged several groups that special classes can be arranged for.

Afterwards, in the 1994 Elementary School Curriculum, the necessity to meet the rights and needs of children in school is stressed again. What this document expands on, though, is the role of the teachers, specifying that they should consider the needs, requirements, experiences, and thoughts of a child while teaching them. Finally, a new Education Act was implemented in 2010 [64]. Compared to the previous Act (which it still built upon), the way autism was handled changed slightly, i.e. it was no longer being treated identically to intellectual disabilities in all cases, but only when an intellectual disability is actually present. According to the Act, everyone should be included in mainstream schooling and placement in special teaching groups should be used only as a provision of last resort. Moreover, the Act prescribes that the student health should become a central activity with a strengthened mandate to prevent the emergence of problems and promote student health and welfare.

The environment for children with autism and their families received some developments over the years as well, starting with the Law regulating Support and Service to Persons with Certain Functional Disabilities [65]. Its contents are focused on improving the environment in which the children with autism live, which, by extension, can have positive effects for their educational performance. It creates opportunities for parents/guardians to relax by providing services that temporarily take care of their child with autism. Alternatively, it also puts measures in place that enables a child with autism to be placed elsewhere if it cannot live at home due to its condition. The Act on Discrimination against Children and the Discrimination Act $[66,67]$ predominantly addressed stigma and discrimination on basis of disability. Their scope includes education, making it so that children with disabilities have as equal an opportunity as possible when attending mainstream education. The only difference 
between the two Acts is that the Discrimination Act expanded the scope of the Act on Discrimination against Children.

Since teachers are predominantly responsible for addressing the SEN of their children in classroom, their education was investigated as well. The Higher Education Ordinance sets out the requirements for teacher training at all levels [68]. In terms of addressing SEN, the curriculum recognizes two different types of special educators: Special Education Needs Coordinators (SENCOs) and special education teachers. Göransson, Lindqvist, and Nilhom explain that the education of both types of special educators is the same in many aspects [69]. According to them, both education paths should lead to a skillset that is needed to work for and with children with SEN, as well as knowledge to develop and lead educational work with the goal to address the needs of all children. They further elaborate that the difference between the two types is that special education teachers are schooled to work in compulsory schools while SENCOs are schooled to work in preschools as well as compulsory schools with the child's whole education environment. In terms of teacher education, this is reflected by the fact that special education teachers receive more individualcentred learning goals (e.g. knowledge of assessment and grading as well as language- and conceptual development), while the education for SENCOs focuses on schools' organisation and learning environment. They finally note that both groups are trained to be able to work in schools for children with intellectual disability. Later on, when implementing the 'Best in class - a new teacher education' proposal [70], mainstream teacher training was changed. Whereas previously teacher training applied to all of mainstream education, it is now subdivided into four categories: pre-primary education, primary education, subject education, and vocational education, each specialising on that specific part of the educational trajectory.

Ultimately, SEN services have existed in the Swedish education system since before the adoption of the UDHR. They also recognised and classified autism as a condition on par with developmental disorders as early as 1985 and later differentiated it from intellectual disabilities in 2010. Additionally, the Swedish system is structured in its approach towards SEN. According to the mapped legislation, SEN should first be addressed in mainstream classrooms to the best of the teacher' abilities. Only when it is no longer feasible to keep a child with SEN in a mainstream classroom, can a transferral to special education be considered. Also, since the municipalities are in charge of their respective primary and secondary schools, the financing of SEN support in these schools is state-governed. 


\subsection{Finland}

Finland has adopted various policies since the UDHR was implemented by the UN. A synopsis of the policies in included in an additional file [see Additional File 6].

When the UDHR was implemented, Finland already had some resemblance of an education system in place [71]. The first elementary schools were established in 1866, though home and church were responsible for a basic education (e.g. reading and writing) before a child would be accepted in an elementary school, which was completely free. Compulsory education was introduced shortly after the First World War, in 1921. After the Second World War, education of children started with elementary school for everybody. Upon completion, there was a choice between two educational trajectories: upper comprehensive schooling, which led to studying in university; or senior primary schooling, which led to studying in vocational schools.

The first notice of allowing children with SEN to follow education came in the Regulation on Special Care for the Mentally Handicapped [72], which allowed for children that were unable to attend mainstream education to receive training separately until the end of their compulsory school age. Though in order for this to apply, they would need to be assessed by trained professionals in order to gauge their possibilities and capabilities. A more inclusive approach to the education of children with SEN came with the ratification of the Basic Education Act [73]. This Act addressed many different aspects of education and the incorporation of children with SEN in the education system. It sets out goals for teaching, clarifies what SEN services are and that, when possible, they should be provided in a mainstream classroom, sets out conditions under which a child may be partially or completely moved to special education, and explains what the personal plans for the organisation of teaching should include, along with whom should be included while drafting. Subsequently, the renewed Finnish Constitution [74] re-emphasized several basic human rights for children with SEN, such as that all children should be treated equally and their right to free basic education.

Over time, special education continued to grow in size, to the point that the Special Education Strategy [75] was drafted in order to create a proposal for a long-term strategy that would improve pre-primary and basic special education. In this Strategy, it was proposed that the primary form of support would need to shift to an earlier support and prevention-based 
approach. The aim of this approach was to reinforce learning and growth and to prevent the magnification and/or escalation of problems relating to learning, development, or social interaction. Additionally, the Strategy urged for the content of special education to improve in a way that decisions on whether a child needs special education would become binding, including resources required, group size of the class, the adaptation of the syllabus, and the capacities of the child. However, it also recognises that it would be necessary to change the process of coming to a decision on SEN slightly, in a way that it should include pedagogic experts as well.

The final document that addressed the provision of services to children with SEN among others is the Student Care Act [76], which can be divided in three themes: its aims, allocating responsibilities, and the student health plan. The aims all refer back to the rights of the children set out in the previously covered documents. In terms of responsibilities, the municipalities in which the educational institution is located are allocated responsibility over the children, the involvement of psychologists or social workers, and, albeit optionally, provide support in organising additional services for educational institutions. Lastly, it introduced a student health plan, which includes details such as the amount of healthcare the child requires, the initiatives to protect the child from bullying, harassment, and a cooperation of different stakeholders that contribute to the child's well-being. Even though it does not specifically target potential SEN of children, it can be useful to keep track of the additional health needs that many of the conditions that cause the SEN require. As such, it has the potential to indirectly benefit the education of children with SEN.

With teachers being predominantly responsible for addressing the SEN of their children, it is crucial to investigate their training as well. The Government Decree on University Degrees [77] sets out the courses in which teachers in Finland are trained. During teacher training, aspiring teachers follow courses on each potential step of the education system: early and pre-primary education, basic education, special education, etc. As such, every teacher has at least a basic understanding of what SEN are and how to approach them in a classroom.

In short, the SEN policy in Finland is incorporated in general education policy. There are few policies aimed towards SEN or disability specifically, yet these topics are broadly covered in the overarching policies that regulate education (e.g. the Basic Education Act). Nevertheless, some form of equity is achieved through the referenced articles from the Constitution and the 
way SEN services are set up in the Acts. This is because legislation dictates that every child should be given the resources and services they need in order to develop themselves to their fullest. It is not specified how SEN services are financed in educational institutions. However, since educational institutions are funded by the state, it is implied that the provision of SEN services falls under this funding as well. Overall, as Finnish basic education system is based on the philosophy of inclusion and all children are supported individually so that they can successfully complete their basic education.

\section{Discussion}

This study aimed to map autism, SEN, and education policies that cover the right and access to education for autistic children, as well as the assistance provided during their education in Denmark, Sweden, and Finland. Additionally, it investigated how inclusion was integrated into respective national education policy using a policy path dependence analysis. This data was compared to the reference framework of UN and EU policy that was already available prior to this study $[17,18]$. As a result, we mapped all relevant SEN policies that affect the education of autistic children as well as their universal right to education in an attempt to create a comprehensive report once the EU mapping exercise is complete with the aim of unveiling both bad and good practices when it comes to SEN education.

As already established in previous work $[17,18]$, the UDHR marked a critical juncture for policy, both internationally and in the EU. When comparing the legislation adopted in the different policy layers to the Danish, Swedish, and Finnish policy environment, this also holds true for these countries. Notably, in the case of Denmark and Sweden, all children were already legally entitled to education prior to the ratification of the UDHR. Also, the approach towards the education of people with disabilities in Denmark and Sweden involved the ratification of policy that specifically addressed this topic on top of the coverage in basic education policy, while Finland has integrated its approach fully in basic education policy. Even though the approaches may differ slightly, the results are comparable.

All three countries have made significant efforts to adapt their education system to offer a place for all children (regardless of physical, mental, or social state), as well as to offer SEN services and support in mainstream education. That is up until the point it stops being in the child's best interest, according to a group of experts that will assess each case individually, to attend mainstream education. In doing so, the UDHR's values on the right to education is 
comprehensively considered in the three Nordic countries. Additionally, the values of UN and EU policy are reflected back in the national policy of these countries. Even though the international documents are not referenced in national policy, the measures that are taken are comparable in that similar outcomes are achieved: an improved education system that is appropriate and accessible for children with and without disability.

One of the aims of this study was to investigate to what extent the education system of the countries under study incorporated inclusive education. While the term itself is never mentioned in any of the legislative documents, the ideology is being adopted in all three countries. All three education systems aim to include as many children in their mainstream education as possible, with additional services, support, or equipment offered where required. This is reinforced by the notion that all educational institutions receive funding from their respective municipality, and by extension from their respective state, to accommodate as many children in their educational institution as possible, taking the health and educational needs of the child into account. Only if the child is burdened by their condition to such an extent that it is no longer feasible to attend mainstream education, will they be transferred to a special educational arrangement (e.g. special school setting, special teaching group, etc). As such, it is safe to say that, while significant steps have already been made towards an inclusive environment, there is still a certain amount of segregation present in the Nordic education systems. Nevertheless, this is not necessarily a fault. While it is important for children with SEN to be included as much as possible in mainstream education for mutual benefit [10], it is also crucial that the education of typical children does not suffer from inclusion practices. As such, exclusion practices should be removed as soon as possible, but measures of segregation may still have a place in the current education system.

It is interesting to note that all three countries under study approach inclusive education from the perspective of the child with SEN. Even though the benefits for typical children to be in contact with children with SEN is well documented [10], it is notable how, for example, guidelines on the guidance of neurotypical children are left out of inclusive education policy, while they do play a crucial factor in inclusive education. Additionally, all three countries emphasise the role of the teacher in addressing SEN in classroom. Therefore, we investigated the teacher training curricula as well and found that all three countries under study include courses on SEN and how to address them in a classroom. Unfortunately, the exact contents of the respective courses could not be reviewed at the time of writing this paper. As such, we 
can assert that teachers in Denmark, Sweden, and Finland all have at least a basic understanding of SEN and how to address them in a classroom.

It has to be noted that there are some contrasts between the three countries. As previously mentioned, Finland incorporates its SEN strategy more in general education policy, while Denmark and Sweden also passed several policies specifically geared towards SEN and disability policy. As a result, the environment in Finland has become less regulated and there are fewer guidelines to help schools formulate their SEN strategies. While this is not an inherently negative situation, it poses the risk that schools fill in the inevitable gaps in legislation locally without national guidance, which may result in a heterogeneous environment for children with SEN to study and develop. Also, while Danish and Swedish education policies strongly imply that their focal point is children, Finnish policy explicitly states so. Consequently, potential room for (mis)interpretation is removed in the application of these policies: children are the focal point and all measures taken by schools or other educational institutions should support them and their development. Additionally, even though all countries under study aim to address SEN for children with disabilities, Finland and Denmark operate without a clear definition of 'disability'. Their policies generally refer to disabilities as 'conditions that inhibit education' and structurally state that teachers should 'take measures to address the corresponding needs', without going into detail as to what kind of needs should be met in what way. Furthermore, while Denmark and Finland predominantly put the educational institutions in charge of the decision-making processes that pertain the child with SEN, Sweden includes family member in the process as well. The inclusion of family in the decision-making process is a factor that has already been reviewed in previous work of EDUCAUS [17]. One particular detail that should be noted in the Swedish system when considering how autism is addressed in education, is its disconnection from intellectual disabilities in recent times, unless the child with autism actually has an intellectual disability. As a result, children with autism no longer run the risk of being sent to a special school based on their condition and have better access to education. Moreover, Finland has taken additional steps to support children with SEN. Instead of starting the process while the child attends primary school, it implemented measures that target preprimary education and special education. In doing so, it aimed to create an educational environment in which learning and developmental conditions could be better addressed. Finally, in recent years, Danish policy has reconsidered the scope of SEN in an attempt to facilitate more children in mainstream classrooms. Now, children that require less than 9 
teaching hours of additional support are not considered to be children with SEN and are to be assisted primarily by the teacher in charge. According to the 2012 "inclusion law" [37], the child must be given additional education, support or personal assistance if needed to solve practical issues attending school, aiding their fundamental right to maximum development. Nevertheless, these measures put more responsibilities on the classroom teachers. The Danish government's expert panel report in 2016 highlighted strengthening of teachers' competencies in working with children with special needs and access to relevant professional support as one of the key challenge areas in the implementation of inclusion.

This scoping review has some limitations that should be accounted for. Firstly, the results of this study cannot be generalized across countries, only within the three countries explored. Secondly, it is challenging to determine how the approaches to SEN are put into practice. Therefore, the results of this paper remain strictly theoretical. Thirdly, during the execution of the search strategy, the N-Lex database was unavailable for Denmark and Finland. A large advantage of using the N-Lex is that it will automatically translate an index term from English to the respective language of the country under investigation. However, since this service was unavailable, we relied on manual translations of index terms. While all synonyms of the translated index term were included, it does not rule out the possibility that some meaning was lost in translation and that that might have affected the outcomes of this paper. To account for this limitation, Danish, Swedish, and Finnish experts were asked to assist in searching and interpreting the legislation for their respective countries. Fourthly, the Danish policy repository only included limited entries pre-1985. As a result, we had to rely on synopses of legislations that predates 1985 or had to acknowledge that the policy path dependence for Denmark would be incomplete. As it stands, there was only one completely unavailable policy document, namely the 1975 law on primary and lower secondary schools. Fifthly, only governmental documents were included in this research. Consequently, potential actions by NGOs were disregarded by this paper, unless their work was adopted in national legislation (e.g. the Charter for Persons with Autism, drafted by Autism-Europe and adopted by the European Parliament). Finally, the scope of this study was limited to autistic children. In other words, autistic adults that are part of the education system were not covered by the contents of this paper, even though they may experience similar challenges in their educational endeavours. 
Lastly, there are some opportunities for further work as well. For instance, it would be beneficial to investigate how inclusion policies are translated in practice in the countries under study. At the time of writing this report, no such investigation has been done, even though it could provide significant improvements either in policy recommendations and/or in the education environment. Also, teacher training should be investigated beyond these Nordic countries. With inclusion becoming more prevalent in the EU, it is crucial that teachers have the knowledge, skills, and competences to adequately address SEN in their classrooms.

\section{Conclusion}

This study provided insight in the SEN policy environment of Denmark, Sweden, and Finland. The values of the UDHR and CRPD were integrated in all education systems under study through national legislation. Mainstream schools offer SEN services and support until participation in mainstream education ceases to be in the child's best interest due to the severity of their SEN. Also, the provision of SEN services is done exclusively through schools. There are no other institutions involved in providing these services. Inclusive education, while not mentioned specifically in national legislation, is a guiding factor in the education systems of the countries under study.

\section{References}

1. American Psychiatric Association. Diagnostic and statistical manual of mental disorders (5th ed.). Washington, DC; 2013.

2. World Health Organisation. International Statistical Classification of Diseases and Related Health Problems 10th Revision [Internet]. 2016 [cited 2018 Nov 15]. Available from: http://apps.who.int/classifications/icd10/browse/2016/en\#/F84.5

3. Lai MC, Lombardo M V., Baron-Cohen S. Autism. Lancet. 2014;383(9920):896-910.

4. Loomes R, Hull L, Mandy WPL. What Is the Male-to-Female Ratio in Autism Spectrum Disorder? A Systematic Review and Meta-Analysis. J Am Acad Child Adolesc Psychiatry [Internet]. 2017 Jun 1 [cited 2018 Aug 23];56(6):466-74. Available from: http://www.ncbi.nlm.nih.gov/pubmed/28545751

5. Ganz M. The lifetime distribution of the incremental societal costs of autism. Arch Pediatr Adolesc Med [Internet]. 2007 Apr 1;161(4):343-9. Available from: http://dx.doi.org/10.1001/archpedi.161.4.343

6. Shattuck PT, Narendorf SC, Cooper B, Sterzing PR, Wagner M, Taylor JL. Postsecondary Education and Employment Among Youth With an Autism Spectrum 
Disorder. Pediatrics [Internet]. 2012 May 14; Available from: http://pediatrics.aappublications.org/content/early/2012/05/09/peds.2011-2864.abstract

7. Warren Z, McPheeters ML, Sathe N, Foss-Feig JH, Glasser A, Veenstra-VanderWeele J. A Systematic Review of Early Intensive Intervention for Autism Spectrum Disorders. Pediatrics [Internet]. 2011 May 1 [cited 2018 Aug 23];127(5):e1303-11. Available from: http://www.ncbi.nlm.nih.gov/pubmed/21464190

8. Carroll J, Bradley L, Crawford H, Hannant P, Johnson H, Thompson A. SEN support: A rapid evidence assessment. 2017.

9. Grindal T, Hehir T, Freeman B, Lamoreau R, Borquaye Y, Burke S. A Summary of the Research Evidence on Inclusive Education. 2016.

10. Grindal T, Hehir T, Freeman B, Lamoreau R, Borquaye Y, Burke S. A Summary of the Research Evidence on Inclusive Education [Internet]. 2016. Available from: https://www.abtassociates.com/sites/default/files/201903/A_Summary_of_the_evidence_on_inclusive_education.pdf

11. United Nations. Universal Declaration of Human Rights [Internet]. 1948. Available from: http://www.un.org/en/udhrbook/pdf/udhr_booklet_en_web.pdf

12. United Nations. Convention on the Rights of Persons with Disabilities [Internet]. 2006. Available from:

http://www.ohchr.org/EN/HRBodies/CRPD/Pages/ConventionRightsPersonsWithDisa bilities.aspx\#3

13. European Commission. Treaty on the Functioning of the European Union [Internet]. 2009. Available from: http://eur-lex.europa.eu/legalcontent/EN/TXT/PDF/?uri=CELEX:12012E/TXT

14. Eurostat. Population change - Demographic balance and crude rates at national level [Internet]. 2018 [cited 2018 Apr 30]. Available from: http://appsso.eurostat.ec.europa.eu/nui/show.do?dataset=demo_gind\&lang=en

15. UNESCO. The Salamanca Statement and Framework for Action on Special Needs Education [Internet]. 1994 [cited 2018 May 19]. Available from: http://www.unesco.org/education/pdf/SALAMA_E.PDF

16. Roleska M, Roman-Urrestarazu A, Griffiths S, Ruigrok AN V., Holt R, van Kessel R, et al. Autism and the right to education in the EU: Policy mapping and scoping review of the United Kingdom, France, Poland and Spain. Jan Y-K, editor. PLoS One [Internet]. 2018 Aug 30 [cited 2019 Apr 26];13(8):e0202336. Available from: http://dx.plos.org/10.1371/journal.pone.0202336 
17. van Kessel R, Roman-Urrestarazu A, Ruigrok A, Holt R, Commers M, Hoekstra RA, et al. Autism and Family Involvement in the Right to Education in the EU: Policy Mapping in the Netherlands, Belgium, and Germany. 2018;

18. Roleska M, Roman-Urrestarazu A, Griffiths S, Czabanowska K, Sherlaw W, Brayne C. Autism and the Right to Education in the EU: Policy Mapping in the United Kingdom, France, Poland and Spain. 2017;

19. Arksey H, O’Malley L. Scoping studies: towards a methodological framework. Int J Soc Res Methodol. 2005 Feb;8(1):19-32.

20. Levac D, Colquhoun H, O’Brien KK. Scoping studies: advancing the methodology. Implement Sci. 2010 Dec;5(1):69.

21. Mahoney J. Path dependence in historical sociology. Theory Soc. 2000;29(4):507-48.

22. Leung L. Validity, reliability, and generalizability in qualitative research. J Fam Med Prim care [Internet]. 2015 [cited 2018 Oct 1];4(3):324-7. Available from: http://www.ncbi.nlm.nih.gov/pubmed/26288766

23. Moher D, Liberati A, Tetzlaff J, Altman DG, PRISMA Group. Preferred reporting items for systematic reviews and meta-analyses: the PRISMA statement. BMJ. 2009 Jul;339:b2535.

24. Mahoney J. Path dependence in historical sociology. Theory Soc [Internet]. 2000;29(4):507-48. Available from:

http://webarchiv.ethz.ch/soms/teaching/OppFall09/MahoneyPathDependence.pdf

25. Pierson P. Increasing Returns, Path Dependence, and the Study of Politics. Am Polit Sci Rev [Internet]. 2000;94(02):251-67. Available from:

http://www.journals.cambridge.org/abstract_S0003055400221059

26. Collier R, Collier D. Shaping the Political Arena Critical Junctures, the Labor Movement, and Regime Dynamics in. 2002 [cited 2018 May 15]; Available from: https://cloudfront.escholarship.org/dist/prd/content/qt8qr1z7gc/qt8qr1z7gc.pdf?t=ok97 a8

27. R Core Team. R: A Language and Environment for Statistical Computing [Internet]. Vienna, Austria; 2018. Available from: https://www.r-project.org/

28. Revelle W. psych: Procedures for Psychological, Psychometric, and Personality Research [Internet]. Evanston, Illinois; 2018. Available from: https://cran.rproject.org/package $=$ psych

29. Cohen J. A Coefficient of Agreement for Nominal Scales. Educ Psychol Meas [Internet]. 1960 Apr 2 [cited 2019 Aug 2];20(1):37-46. Available from: 
http://journals.sagepub.com/doi/10.1177/001316446002000104

30. Folketing. The Constitutional Act of Denmark [Internet]. Folketinget; 1953. Available from:

https://www.thedanishparliament.dk/Publications/ /media/PDF/publikationer/English/ The_Constitutional_Act_Of_Denmark_2013.pdf.ashx

31. Danish Ministry of Education. Folkeskolens Specialundervisning [Internet]. 1961. Available from:

https://www.foxylex.dk/media/betaenkninger/Folkeskolens_specialundervisning.pdf

32. Danish Ministry of Education. Executive Order on Primary Schools Special Education for Students with General Learning Disabilities [Internet]. Danish Ministry of Education; 1978. Available from:

https://www.retsinformation.dk/Forms/R0710.aspx?id=73318

33. Danish Ministry of Education. Circular on public school special education and other special educational assistance [Internet]. 1979. Available from: https://www.retsinformation.dk/Forms/R0710.aspx?id=74569

34. Danish Ministry of Education. Statement of opinion assessments, etc. for students receiving special education and other special education assistance in primary and lower secondary schools [Internet]. Danish Ministry of Education; 1980. Available from: https://www.retsinformation.dk/Forms/R0710.aspx?id=72959\#

35. Danish Ministry of Education. Notice of public school special education and other special educational assistance [Internet]. 1990 [cited 2018 Dec 12]. Available from: https://www.retsinformation.dk/Forms/R0710.aspx?id=73491

36. Danish Ministry of Education. Guidance on primary school special education and other special education assistance [Internet]. 2008. Available from: https://www.retsinformation.dk/Forms/R0710.aspx?id=114197

37. Danish Parliament. Folkeskole Law amending the Law on the elementary school, the Act on Private Independent Schools etc. Act and the folk high schools, continuation schools, home schools and trade schools (boarding schools). [Internet]. 2012 [cited 2018 Dec 12]. Available from: https://www.ft.dk/samling/20111/lovforslag/L103/som_vedtaget.htm\#dok

38. Danish Ministry of Education. About the Folkeskole [Internet]. Danish Ministry of Education; 2018. Available from: http://eng.uvm.dk/primary-and-lower-secondaryeducation/the-folkeskole/about-the-folkeskole

39. Danish Ministry of Education. Law on Primary Education [Internet]. Aarhus 
University; 1975. Available from: https://danmarkshistorien.dk/leksikon-ogkilder/vis/materiale/lov-om-folkeskolen-26-juni-1975/

40. Danish Ministry of Education. Circular on public school special education of pupils with behavioral problems and mental disorders [Internet]. 1972 [cited 2018 Dec 12]. Available from: https://www.retsinformation.dk/Forms/R0710.aspx?id=74072

41. Danish Ministry of Education. Circular on public school special education of learning disabled students [Internet]. 1974 [cited 2018 Dec 12]. Available from: https://www.retsinformation.dk/Forms/R0710.aspx?id=74130

42. Danish Ministry of Education. Order on notification obligations for voice disorders, severe cases of dyslexia and reading weakness [Internet]. 1978 [cited 2018 Dec 12]. Available from: https://www.retsinformation.dk/Forms/R0710.aspx?id=73142

43. Danish Ministry of Education. Circular on special education for students in the 8th10th grade who need special support in the subject Danish [Internet]. 1978 [cited 2018 Dec 12]. Available from: https://www.retsinformation.dk/Forms/R0710.aspx?id=74637

44. Danish Ministry of Education. Circular on amending the Law on the elementary school, the law on special education for adults and amending the Law on leisure education, etc. [Internet]. 1978 [cited 2018 Dec 12]. Available from: https://www.retsinformation.dk/Forms/R0710.aspx?id=74179

45. Danish Ministry of Education. Notice of public school special education of students with general learning disabilities [Internet]. 1978 [cited 2018 Dec 12]. Available from: https://www.retsinformation.dk/Forms/R0710.aspx?id=73318

46. Danish Ministry of Education. Notice of public school special education and other special educational assistance to students with language or speech problems [Internet]. 1979 [cited 2018 Dec 12]. Available from: https://www.retsinformation.dk/Forms/R0710.aspx?id=73344

47. Danish Ministry of Education. Notice of public school special education and other special educational assistance for the hearing impaired pupils [Internet]. 1979 [cited 2018 Dec 12]. Available from: https://www.retsinformation.dk/Forms/R0710.aspx?id=73348

48. Danish Ministry of Education. Notice of public school special education and other special educational assistance to visually impaired students [Internet]. 1979 [cited 2018 Dec 12]. Available from: https://www.retsinformation.dk/Forms/R0710.aspx?id=73347 
49. Danish Ministry of Education. Notice of public school special education and other special educational assistance for disabled students [Internet]. 1979 [cited 2018 Dec 12]. Available from: https://www.retsinformation.dk/Forms/R0710.aspx?id=73345

50. Danish Ministry of Education. Notice of public school special education and other special educational assistance [Internet]. 2014 [cited 2018 Dec 12]. Available from: https://www.retsinformation.dk/Forms/R0710.aspx?id=163941

51. Danish Ministry of Education and Research. Order on the education for professional bachelor as a teacher in primary school [Internet]. 2015. Available from: https://www.retsinformation.dk/Forms/R0710.aspx?id=174218

52. Danish Ministry of Education. Guidance on primary school special education and other special educational assistance [Internet]. 2013 [cited 2019 Aug 22]. Available from: https://www.retsinformation.dk/Forms/R0710.aspx?id=145638

53. Danish Ministry of Education. Executive Order: Notice of public school special education and other special educational assistance [Internet]. 2012. Available from: https://www.retsinformation.dk/Forms/R0710.aspx?id=141578

54. Danish Ministry of Education. Executive Order on Primary Schools Special Education and Other Special Educational Assistance [Internet]. 2014. Available from: https://www.retsinformation.dk/Forms/R0710.aspx?id=163980

55. Danish Ministry of Children, Education and GE. Afrapportering af inklusionseftersynet: Et overblik over den samlede afrapportering [Internet]. 2016 [cited 2019 Aug 27]. Available from: https://www.altinget.dk/misc/160511 PIXI version inklusion040516WEB.pdf

56. Nordström S. Hjälpskolan och särskolan i Sverige t.o.m. 1921 [The School for the Back- ward and Severely Mentally Retarded in Sweden up to 1921]. [Internet]. Vol. 119, Årsböcker i svensk undervisningshistoria. Stockholm: Almqvist \& Wiksell; 1968 [cited 2018 Dec 5]. Available from: http://www.tam-arkiv.se/share/proxy/alfresconoauth/tam/content/workspace/SpacesStore/b9ef3ccf-f549-444a-a3d72f9dea8055e0/download/ASU_119.pdf

57. Fischer M, Karlsson M, Nilsson T. The Sooner the Better? Compulsory Schooling Reforms in Sweden * [Internet]. 2014 [cited 2018 Dec 11]. Available from: https://www.ed.lu.se/media/ed/seminar_papers/reform_ulf_150212.pdf

58. Swedish Ministry of Education. Curriculum for Compulsory Education. 1962.

59. Swedish Ministry of Education. Special School Regulation [Internet]. Sweden; 1965. Available from: https://beta.lagrummet.se/rinfo/publ/sfs/1965:478/konsolidering/1994- 
07-01

60. Sveriges Riksdag. The Constitution of Sweden [Internet]. 1974. Available from: http://www.equalrightstrust.org/ertdocumentbank/CONSTITUTION OF SWEDEN.pdf

61. Swedish Ministry of Education. School Regulation Act [Internet]. Sweden; 1971. Available from: https://beta.lagrummet.se/rinfo/publ/sfs/1971:235/konsolidering/199007-01

62. Swedish Ministry of Education. Education Act [Internet]. Sweden; 1985. Available from: http://rkrattsbaser.gov.se/sfst?bet=1985:1100

63. Swedish Ministry of Education. Primary School Regulation [Internet]. 1988 [cited 2018 Oct 9]. Available from:

https://beta.lagrummet.se/rinfo/publ/sfs/1988:655/konsolidering/1994-07-01

64. Swedish Ministry of Education. Education Act [Internet]. 2010 [cited 2018 Dec 12]. Available from: https://beta.lagrummet.se/rinfo/publ/sfs/2010:800/konsolidering/2017$11-01$

65. Swedish Ministry of Social Affairs. Law regulating Support and Service to Persons with Certain Functional Disabilities [Internet]. 1993 [cited 2018 Dec 12]. Available from: https://beta.lagrummet.se/rinfo/publ/sfs/1993:387/konsolidering/2017-07-01

66. Swedish Ministry of Education. Act on Discrimination against Children [Internet]. 2006. Available from: http://rkrattsbaser.gov.se/sfst?bet=2006:67

67. Swedish Ministry of Culture. Discrimination Act [Internet]. 2008 [cited 2018 Dec 12]. Available from: https://beta.lagrummet.se/rinfo/publ/sfs/2008:567/konsolidering/201707-01

68. Swedish Ministry of Education. Higher Education Ordinance [Internet]. 1993. Available from: https://beta.lagrummet.se/rinfo/publ/sfs/1993:100/konsolidering/201710-01

69. Göransson K, Lindqvist G, Nilholm C. Voices of special educators in Sweden: A totalpopulation study. Educ Res [Internet]. 2015;57(3):287-304. Available from: http://dx.doi.org/10.1080/00131881.2015.1056642

70. Swedish Ministry of Education. Best in class - a new teacher education (Government Bill 2009/10:89) [Internet]. 2010. Available from: https://riksdagen.se/sv/dokumentlagar/dokument/proposition/bast-i-klassen---en-ny-lararutbildning_GX0389/html

71. Kärnä E. History of special education in Finland.pdf. Int J Spec Educ. 1995;10(2):3753. 
72. Finnish Ministry of Social Affairs and Health. Regulation on Special Care for the Mentally Handicapped [Internet]. Oikeusministeriö, Edita Publishing Oy; 1977. Available from:

https://www.finlex.fi/fi/laki/smur/1977/19770988?search\%5Bkohdista\%5D=koko\&se $\operatorname{arch} \% 5 \mathrm{Ball} \% 5 \mathrm{D}=\&$ search $\% 5 \mathrm{Bany} \% 5 \mathrm{D}=$ koulutus opetus\&search $\% 5 \mathrm{Bphrase} \% 5 \mathrm{D}=\&$ search $\% 5 \mathrm{~B}$ without $\% 5 \mathrm{D}=\&$ search $\% 5 \mathrm{Btype} \% 5 \mathrm{D}=$ te kstihaku

73. Finnish Ministry of Education. Basic Education Act [Internet]. 1998. Available from: https://www.finlex.fi/en/laki/kaannokset/1998/en19980628.pdf

74. Finnish Ministry of Justice. The Constitution of Finland [Internet]. 1999. Available from: https://www.finlex.fi/fi/laki/kaannokset/1999/en19990731.pdf

75. Finnish Ministry of Education. Special Education Strategy [Internet]. 2006 [cited 2018 Nov 20]. Available from:

http://julkaisut.valtioneuvosto.fi/bitstream/handle/10024/79498/tr47.pdf

76. Finnish Ministry of Education, Finnish Ministry of Culture. Student Care Act [Internet]. 2013. Available from: https://www.finlex.fi/fi/laki/ajantasa/2013/20131287

77. Finnish Ministry of Education. Government Decree on University Degrees (794/2004) [Internet]. 2004. Available from:

https://www.finlex.fi/en/laki/kaannokset/2004/en20040794.pdf 


\section{Additional Files}

Additional File 1

Title: Key characteristics of the Nordic education systems.

\begin{tabular}{|c|c|c|c|c|}
\hline & $\begin{array}{l}\text { Compulsory } \\
\text { Education }\end{array}$ & Centralization & General Outline of Education & Key Features \\
\hline Denmark & Age 6 to 16 & Centralized & $\begin{array}{l}1 \text { pre-school year } \\
9 \text { years of integrated primary } \\
\text { and lower secondary education } \\
\text { with an optional tenth year } \\
3 \text { years of secondary education; } \\
\text { length of other education } \\
\text { programs depends on study of } \\
\text { choice }\end{array}$ & $\begin{array}{l}\text { Education for everyone } \\
\text { Education is focuedon } \\
\text { life-long learning }\end{array}$ \\
\hline Sweden & Age 7 to 16 & Decentralized & $\begin{array}{l}1 \text { pre-school year } \\
9 \text { years of primary education } \\
\text { equal to the length of } \\
\text { compulsory education }\end{array}$ & $\begin{array}{l}\text { Government sets goals } \\
\text { for the education system } \\
\text { Education is based } \\
\text { around life-long }\end{array}$ \\
\hline Finland & Age 7 to 16 & Centralized & $\begin{array}{l}1 \text { (optional) year of early } \\
\text { childhood education } \\
9 \text { years of primary education in } \\
\text { a single structure } \\
4 \text { years of upper secondary } \\
\text { education }\end{array}$ & $\begin{array}{l}\text { Equity in education } \\
\text { A system based on trust } \\
\text { and responsibility } \\
\text { A major focus on life- } \\
\text { long learning } \\
\text { Good learning outcomes } \\
\text { are achieved at average }\end{array}$ \\
\hline
\end{tabular}

Data gathered from the Eurydice Network: https://eacea.ec.europa.eu/nationalpolicies/eurydice/national-description_en

Description: This table gives a brief overview of the core components of the Nordic education systems. 


\section{Additional File 2}

Title: An overview of the specific policies and their values of the United Nations and

European Union

\begin{tabular}{|c|c|c|c|}
\hline & Year & Policy & Brief Description of Values \\
\hline \multirow{6}{*}{ United Nations } & 1948 & Universal Declaration of Human Rights & Lays down the right to education for every child in the United Nations, including children with SEN. \\
\hline & 1959 & Declaration on the Rights of the Child & Establishes the right for children to receive appropriate treatment that corresponds to their condition. \\
\hline & 1971 & $\begin{array}{l}\text { Declaration on the Rights of Mentally Retarded } \\
\text { Persons }\end{array}$ & $\begin{array}{l}\text { Defines the right for people with developmental, intellectual, and learning conditions to receive appropriate education to } \\
\text { maximise their potential. }\end{array}$ \\
\hline & 1975 & Declaration on the Rights of Disabled Persons & Expands the scope of the 1975 Declaration to include all children with disabilities. \\
\hline & 1989 & Convention on the Rights of the Child & Expands the role of parents in the development of a child with SEN. \\
\hline & 1994 & Salamanca Statement & $\begin{array}{l}\text { Reemphasizes the fundamental right to education for all children, as well as acknowledges that a wide diversity in special } \\
\text { education needs exist and that they should be addressed properly. }\end{array}$ \\
\hline \multirow{8}{*}{ European Union } & 1952 & European Convention on Human Rights & $\begin{array}{l}\text { A binding version of the Universal Declaration of Human Rights that applies to all European States. Adopted by the Council } \\
\text { of Europe. }\end{array}$ \\
\hline & 1992 & Charter for Persons with Autism & $\begin{array}{l}\text { Emphasises the right to accessible and appropriate education for children with autism. Adopted formally by the European } \\
\text { Parliament in } 1996 \text {. }\end{array}$ \\
\hline & 1997 & Treaty of Amsterdam & Reiterates that discrimination of any kind on the basis of disability is prohibited. \\
\hline & 2000 & $\begin{array}{l}\text { Charter of Fundamental Rights of the European } \\
\text { Union }\end{array}$ & Pools all previously stated rights and freedoms into a single document that unifies values across the EU. \\
\hline & 2009 & $\begin{array}{l}\text { Treaty on the Functioning of the European } \\
\text { Union }\end{array}$ & Delegates the competence of education completely to the EU Member States. \\
\hline & 2010 & European Disability Strategy 2010-2020 & $\begin{array}{l}\text { Aims to empower people with disabilites, acknowledges that children with SEN are often not included in mainstream } \\
\text { education, calls for inclusion. }\end{array}$ \\
\hline & 2015 & Written Declaration on Autism & Calls for an autism-specific EU strategy with the main focus to better understand autism. \\
\hline & 2018 & General Data Protection Regulation & $\begin{array}{l}\text { Consent is required to access health data, which can complicate the communication between the many parties involved in } \\
\text { addressing health and SEN of a child with autism. }\end{array}$ \\
\hline
\end{tabular}

Description: This overview provides a list of the core values of the policies that involved

human rights, autism, and special education that were implemented by the United Nations

and the European Union.

\section{Additional File 3}

Title: The source code used to calculate the inter-rater reliability.

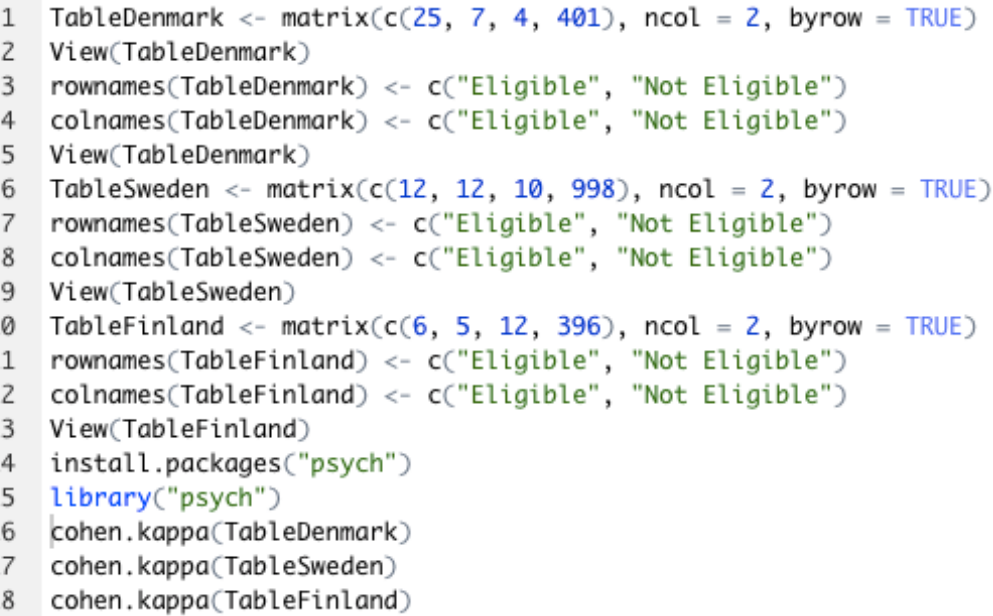

Description: This source code shows the number of articles deemed eligible and non-eligible

by both authors, how many they agreed on, and includes all details on how Cohen's Kappa

was calculated for all three countries to determine inter-rater reliability. 


\section{Additional File 4}

\section{Title: A chronological overview and description of the Danish policies on education and SEN}

\begin{tabular}{|c|c|c|}
\hline Year & Policy & Description \\
\hline 1953 & Danish Consititution & Reaffirmed that all children of school age shall be entitled to free instruction in primary schools \\
\hline 1961 & Folkeskolens Specialundervisning & Recognised that children with SEN have additional needs that need to be met \\
\hline 1978 & $\begin{array}{l}\text { Executive Order on Primary Schools } \\
\text { Special Education for Students with } \\
\text { General Learning Disabilities }\end{array}$ & $\begin{array}{l}\text { Acknowledged the importance of supporting children with SEN with the explicit aim of promoting their } \\
\text { development into economically active adults }\end{array}$ \\
\hline 1979 & $\begin{array}{l}\text { Circular on public school special education } \\
\text { and other special educational assistance }\end{array}$ & $\begin{array}{l}\text { Recognised the importance of organising SEN education in a way that considered the "total needs" of } \\
\text { each individual } \\
\text { Specified a maximum class size of } 6 \text { children } \\
\text { It was made possible to extend the duration of mandatory education by up to } 1 \text { year, where this was } \\
\text { deemed to be in the individual's best interest }\end{array}$ \\
\hline 1979 & $\begin{array}{l}\text { Guidance on special education of students } \\
\text { with general learning difficulties and } \\
\text { Guidelines for referral of pupils to special } \\
\text { education and other special educational } \\
\text { assistance }\end{array}$ & $\begin{array}{l}\text { Developed the SEN environment by: } \\
\text { (1) emphasizing the importance of recognising SEN early; } \\
\text { (2) outlining that a second tier of support should be provided at a county level next to the municipal } \\
\text { level; and } \\
\text { (3) stressing the importance of always including the parents of the child in discussions with the schools } \\
\text { and the authorities }\end{array}$ \\
\hline 1980 & $\begin{array}{l}\text { Statement of opinion assessments, etc. for } \\
\text { students receiving special education and } \\
\text { other special education assistance in } \\
\text { primary and lower secondary schools }\end{array}$ & $\begin{array}{l}\text { Quantified how success was measures for children with SEN, as benchmarking against typical children } \\
\text { would be inappropriate } \\
\text { Where there was agreement between school, student and parents, formal grading could be omitted in } \\
\text { favour of a "written opinion" which detailed the extent to which the student with SEN had achieved their } \\
\text { individual goals in each subject }\end{array}$ \\
\hline 1990 & $\begin{array}{l}\text { Special Education and Other Special } \\
\text { Assistance in Folkeskolen }\end{array}$ & $\begin{array}{l}\text { Replaced all specific guidelines for all specific conditions that were set out earlier with one overarching } \\
\text { document } \\
\text { Emphasised the need to look at the individual student's specific needs and less attention on the specific } \\
\text { diagnosis or type of handicap } \\
\text { De-categorized the way to talk about students with special needs } \\
\text { The role of the pedagogical-psychological service (PPR) in the municipality was emphasised such that } \\
\text { the local PPR should decide if a student needed special education or other special assistance }\end{array}$ \\
\hline 2008 & $\begin{array}{l}\text { Guidance on primary school special } \\
\text { education and other special educational } \\
\text { assistance }\end{array}$ & $\begin{array}{l}\text { Development towards a holistic approach to SEN } \\
\text { A specified focus on the child's academic, personal and social potentials and competencies in the } \\
\text { community } \\
\text { Recognition that these objectives were largely an issue involving the whole teaching team and the entire } \\
\text { school's activities, rather than a task for the individual teacher }\end{array}$ \\
\hline 2012 & $\begin{array}{l}\text { Folkeskole Law amending the Law on the } \\
\text { elementary school, the Act on Private } \\
\text { Independent Schools etc. Act and the folk } \\
\text { high schools, continuation schools, home } \\
\text { schools and trade schools (boarding } \\
\text { schools) }\end{array}$ & $\begin{array}{l}\text { Reduce the number of students who receive special education outside of the mainstream classes from } \\
\text { around } 6 \% \text { of all student to no more than } 4 \% \text { by: } \\
\text { (1) re-classifying children who require less than } 9 \text { hours of additional support as children without SEN; } \\
\text { (2) giving the local municipality and the school director a more decisive role in the visitation of } \\
\text { students to special education }\end{array}$ \\
\hline 2012 & $\begin{array}{l}\text { Executive Order: Notice of public school } \\
\text { special education and other special } \\
\text { educational assistance }\end{array}$ & $\begin{array}{l}\text { Change the procedures concerning SEN policy for more effective management by local municipal } \\
\text { authorities: } \\
\text { child needs }<9 \text { hours support the principal decides whether PPR shall be involved; if } 9 \text { hours or more of } \\
\text { support are needed the child shall be referred to PPR by the principal. The PPR evaluation, presented to } \\
\text { the parents and eventually the pupil, describes the special needs of the pupil and makes } \\
\text { recommendations to the school principal concerning how these needs can be met in the education } \\
\text { system; } \\
\text { (2) Parent and pupil involvement and access to PPR was changed. Above } 9 \text { hours of support the parents, } \\
\text { and eventually the pupils, can ask for an evaluation by PPR. Below } 9 \text { hours, it is solely up to the } \\
\text { principal to decide whether PPR shall be involved }\end{array}$ \\
\hline 2013 & $\begin{array}{l}\text { Guidance on primary school special } \\
\text { education and other special educational } \\
\text { assistance }\end{array}$ & $\begin{array}{l}\text { The provision that SEN services or assistance should be based on a professional evaluation and never on } \\
\text { economic resources is no longer mentioned }\end{array}$ \\
\hline 2014 & $\begin{array}{l}\text { Executive Order: Notice of public school } \\
\text { special education and other special } \\
\text { educational assistance }\end{array}$ & $\begin{array}{l}\text { Central role of PPR, the parents (and student) and teacher in the visitation procedure for SEN sevices was } \\
\text { replaced by the school pricipal as over-all decision-making power (on behalf of the municipal } \\
\text { authorities) }\end{array}$ \\
\hline 2015 & $\begin{array}{l}\text { Order on the education for professional } \\
\text { bachelor as a teacher in primary school }\end{array}$ & $\begin{array}{l}\text { Competence objectives for the teacher's basic subject } \\
\text { (1) Student learning and development: involves the ability to create communities and facilitate student } \\
\text { learning and development, lead learning processes that foster the development of individual, social and } \\
\text { communication skills, and conflict management in diverse social contexts } \\
\text { (2) General teaching competence: deals with the framework for school teaching, including learning } \\
\text { environments and differentiation, class leadership, teaching didactic potentials, collaboration between } \\
\text { colleagues, resource persons, school and home as well as research methodological prerequisites for } \\
\text { assessing and applying research results } \\
\text { (3) Special education: addresses reasoned planning, implementation and evaluation of specially } \\
\text { designed teaching of students who are in complicated learning situations }\end{array}$ \\
\hline
\end{tabular}


$2016 \quad$ Expert Panel Report: Afrapportering af inklusionseftersynet - Et overblik over den samlede afrapportering
Reviewed inclusive education in Denmark and made two major conclusion

(1) Inclusive education started positive trends in the overal welfare of students;

(2) Eight major challenge areas still restrict inclusive education:

(a) strengthening inclusive learning environments;

(b) focusing on students' needs in learning and well-being and engaging students;

(c) increased focus on students' social and personal competencies

(d) better prioritization of efforts and resources at all levels;

(e) strengthening proactive rather than reactive measures;

(f) improving access to professional knowledge and help such as PPR

(g) strengthening competencies of teaching staff in working with children with special needs

(h) strengthening parental involvement and responsibility

Description: A point by point overview of the implications of each respective policy that was analysed for Denmark.

\section{Additional File 5}

Title: A chronological overview and description of the Swedish policies on education and SEN.

\begin{tabular}{ll}
\hline Year & Policy \\
\hline 1962 & Curriculum for Compulsory Education
\end{tabular}

Curriculum for Compulsory Education

\begin{tabular}{ll}
1965 & Special School Act \\
\hline 1971 & School Regulation Act
\end{tabular}

\section{Description}

Schools should support children's development towards free, independent, and harmonious people, considering the child's individuality and qualifications

Special needs education should be offered to those who needed it and eight special classes were offered for children having different kinds of disabilities Developmentally delayed children are a group that requires SEN services

Stressed the importance of addressing SEN in mainstream schools

Teachers were put in charge to address these SEN in their classrooms

Introduced the potential need for additional or specialised equipment in order to adequately fulfil specific SEN

$1974 \quad$ Swedish Constitution

wo major changes to education:

(1) The personal, economic, and cultural well-being of the individual needs to be the primary objective of public activity. Particularly, the public institutions shall be obligated to ensure the right to health, employment, housing and education, and to promote social care and social security; (2) All children covered by compulsory schooling are entitled to free education at public schools

\section{Chapter 1}

Every child shall have equal access to education, regardless of their gender, geographical location, social, and economic conditions

Children who are unable to attend public education as a result of their intellectual or learning disability, will be allowed to attend compulsory schools for pupils with learning disabilities

Laws regarding intellectual and learning disabilities in children also applied among others to children with autism

Chapter 3

Children in general shall be admitted to regular primary and secondary school

A school form called special school is accessible if necessary only for children who are visually impaired, deaf, hard of hearing and have severe language impairment

Children who are unable to meet the goals as a result of their intellectual disability will be admitted to schools for pupils with learning disabilities

Chapter 6

Education in schools for the learning disabled is aimed to give developmentally delayed children and adolescents education as equivalent to elementary schools and upper secondary school as possible, taking the conditions of each student into account

This iteration of schools for children with intellectual and learning disabilities includes elementary education and secondary education 


\begin{tabular}{|c|c|c|}
\hline 1988 & Primary School Regulation & $\begin{array}{l}\text { Reiterates the necessity to provide special support measures for children that experience difficulty in } \\
\text { schoolwork } \\
\text { Special education should be provided for pupils in need of special support } \\
\text { Additional support should primarily be provided within the regular class to which the student belongs } \\
\text { Groups that special classes can be arranged for, namely 1) children with significant physical conditions; } \\
\text { 2) children with pronounced social and emotional disorders; and 3) children with other prominent } \\
\text { difficulties with schoolwork } \\
\text { Special education shall resemble the education the child cannot participate in as much as possible (e.g. } \\
\text { primary and secondary mainstream education) }\end{array}$ \\
\hline 1993 & $\begin{array}{l}\text { Law regulating Support and Service to } \\
\text { Persons with Certain Functional } \\
\text { Disabilities }\end{array}$ & $\begin{array}{l}\text { Measures being taken to better support autistic people among others in order to improve their general } \\
\text { environment: } \\
\text { (1) a short stay away from home for the autistic child to allow the parents or guardians a change of } \\
\text { environment and to have an opportunity for recreation } \\
\text { (2) short-term supervision for children older than } 12 \text { years before and after school } \\
\text { (3) should a child with autism be unable to reside with its family, a replacement home can be arranged } \\
\text { where the child will move to and where it can receive the special care is requires }\end{array}$ \\
\hline 1993 & Higher Education Act & $\begin{array}{l}\text { Sets out the requirements for teacher education at all levels } \\
\text { All mainstream school teachers are trained to assess the needs and prerequisites of their students' } \\
\text { educational and developmental progress and act accordingly } \\
\text { Teachers for special education receive additional specialization courses that focus, among others, on } \\
\text { (1) Language, writing and reading development; } \\
\text { (2) Visual impairment; } \\
\text { (3) Severe language impairment; and } \\
\text { (4) Developmental impairment }\end{array}$ \\
\hline 1994 & Elementary School Curriculum & $\begin{array}{l}\text { Every student's rights are to be met in school based on their prerequisites and needs } \\
\text { Teachers have to take into consideration and plan based on each individual's needs, prerequisites, } \\
\text { experiences and thoughts }\end{array}$ \\
\hline 2006 & Act on Discrimination against Children & $\begin{array}{l}\text { Children cannot be discriminated against on the basis of disability among others } \\
\text { This Act applied to all forms and levels of education, as well as other activities covered by the } 1985 \\
\text { Education Act } \\
\text { Assigned the responsibility of equal treatment within a specific institution to the head of that particular } \\
\text { institution }\end{array}$ \\
\hline 2008 & Discrimination Act & $\begin{array}{l}\text { Replaced the Act on Discrimination against Children } \\
\text { Expanded the scope from children to every person in Sweden }\end{array}$ \\
\hline 2010 & $\begin{array}{l}\text { Best in class - a new teacher education } \\
\text { (Government Bill 2009/10:89) }\end{array}$ & $\begin{array}{l}\text { Replaced Bachelor/Master of Education with four specialised degrees } \\
\text { (1) Degree in pre-primary education } \\
\text { (2) Degree in primary education } \\
\text { (a) Pre-primary class and years } 1-3 \text { of compulsory school } \\
\text { (b) Years } 4-6 \text { of compulsory school } \\
\text { (c) Out-of-school care } \\
\text { (3) Degree in subject education } \\
\text { (a) Years 7-9 of compulsory school } \\
\text { (b) Upper-secondary school } \\
\text { (4) Degree in vocational education }\end{array}$ \\
\hline
\end{tabular}

Description: A point by point overview of the implications of each respective policy that was analysed for Sweden. 


\section{Additional File 6}

\section{Title: A chronological overview and description of the Finnish policies on education and}

SEN.

\begin{tabular}{llc}
\hline Year & Policy & Degulation on Special Care for the \\
\hline 1977 & Regulally Handicapped & Int \\
& & \\
& & \\
\hline 1998 & Basic Education Act &
\end{tabular}

\section{Description}

Introduced the possibility for children that are barred from attending regular schools due to their condition to follow training courses until the year in which they turn 16

These children need to be assessed by a team of trained professionals in order to gauge their capacity as bjectively and accurately as possible

Teaching should promote the conditions for children to participate in their own education and, by extension, develop themselves during their lives

The responsibility of providing education to children that are of compulsory education age lie with the municipality

Children that require additional support or schooling in their education, must be provided with that support in accordance with the learning plan is drafted for them in a collaboration between teacher, student, and parent or guardian

SEN services consist of special education and other support provided

Special education is organized with a high priority on the child's needs, while keeping in mind the environment in which the teaching is organised and the context of parallel education (e.g. other children in the same classroom that do not have SEN)

In cases where these circumstances do not favour the child in question, the teaching may be partly or completely given in a special class or other appropriate place

A personal plan for the organization of teaching should be provided to the child and must be drafted in cooperation with the child and the legal guardian as well as indicate the provision of education and other support in accordance with the decision to provide SEN services to the child

A child's study can be divided if completion of elementary education would be unreasonable given the child's circumstances or if the heal th of the child demands as such

Several basic rights that are particularly applicable to children with SEN were reiterated

(1) Everyone is equal before the law;

(2) Children have to be treated equally and they need to be allowed to influence matters that relate to themselves according to their level of development;

(3) Everyone has the right to free basic education;

(4) Public institutions need to guarantee an equal opportunity for everyone to receive other educational services in accordance with their ability and special needs, as well as for self-development without prevention by economic factors

$2004 \quad$ Government Decree on University Sets out the professional competences taught in teacher education, which include among others Degrees

(1) Early and pre-primary education

(2) Basic education

(3) Special needs education

Aimed to create a proposal for a long-term strategy for the development of pre-primary and basic special education

Acknowledged the growth in special education of recent years

Proposed that the practice at the time needed to shift towards an earlier support and prevention-based approach, and that this was to be adopted as the primary form of support, even before a decision on whether a child requires special education would be made

Advocated that special education decisions received stronger content, meaning that a decision on whether a child is to receive special education would now explicitly and bindingly cover the place that the special education would be given, the resources required for special education, the group size the child should be placed in, and syllabus adapted to the SEN and capacity of the child

Recognised the necessity for pedagogic expertise to be included in this process of decision-making Claimed that inclusion of early childhood education in the education system would allow special-needs children to proceed flexibly and safely from early childhood to pre-primary and further to basic education 
(1) promote student learning, health and welfare and inclusion and to prevent the emergence of problems (2) contribute to the school community and student well-being of the environment, health and safety, accessibility, community activities, as well as cooperation between home and educational institution; (3) ensure early support for those who need it;

(4) ensure equal access and quality of students' learning required by the service; and

(5) confirm the establishment and management functional entity, and a horizontal collaborative study service

Put several responsibilities with the municipalities in which the educational institution is located: (1) The students in the institutions that provide preschool education, basic education, secondary education;

(2) Arrange psychologist and social worker services to students even when the education provider is private or public;

(3) Option to provide assistance in arranging supportive services that education providers can use

Introduced the student health plan, which should be developed in collaboration with school personnel, students and their guardians, and have the following contents:

(1) an estimate of the total needs of student health and the student health services available;

(2) the institution's actions to promote student health and provide necessary support services;

(3) a cooperation organized by the students, their families, those who work at educational institutions, and other factors that contribute to student's well-being;

(4) a plan for how students should be protected from violence, bullying and harassment; and

(5) measures to implement and follow up on the student health plan. 


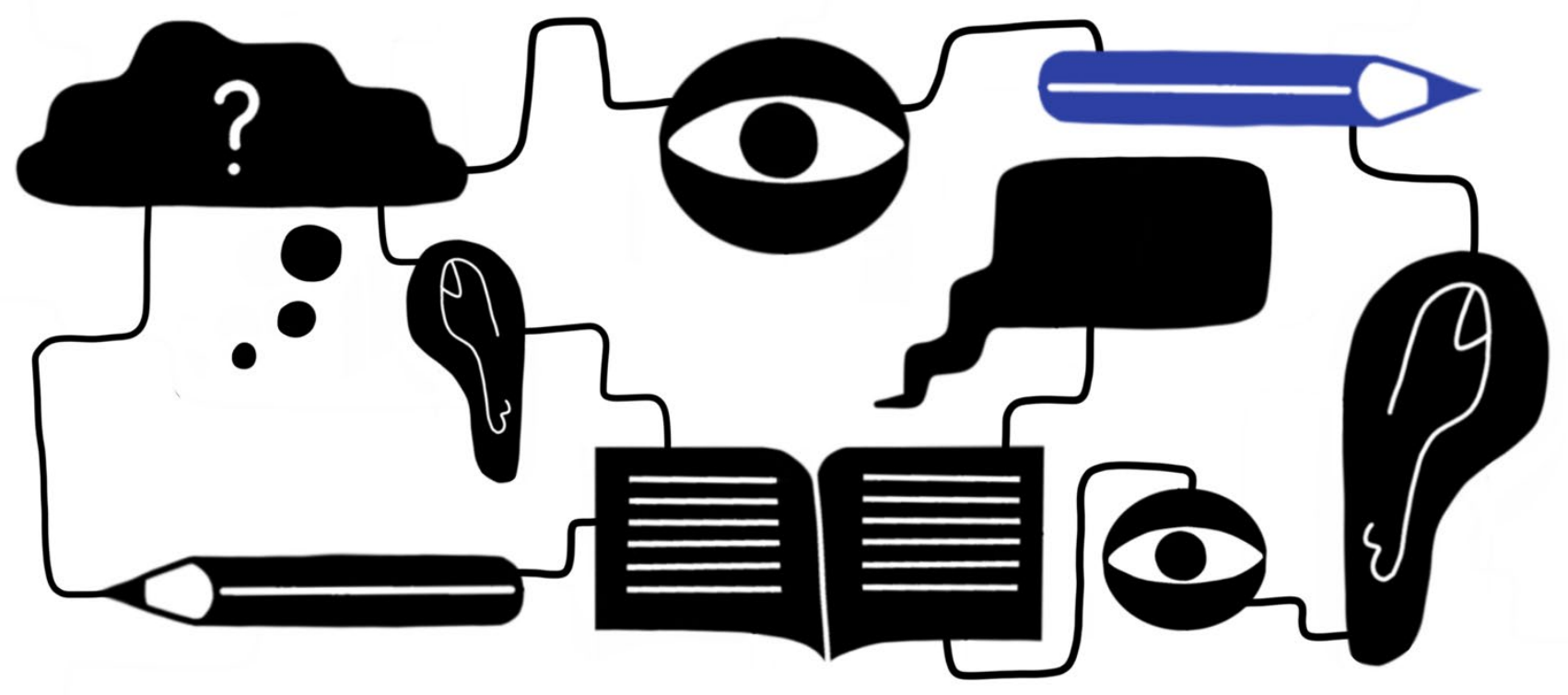

\section{Chapter Three}

Teacher Roles and Responsibilities

\section{Published as:}

van Kessel, R., Steinhoff, P., Varga, O., Breznoščáková, D., Czabanowska, K., Brayne, C., Baron-Cohen, S., Roman-Urrestarazu, A. (2020). Autism and education-Teacher policy in Europe: Policy mapping of Austria, Hungary, Slovakia and Czech Republic. Research in Developmental Disabilities, 105(C). DOI: 10.1016/J.RIDD.2020.103734 [IF(2019): 1,836] 


\begin{abstract}
Background: This report maps autism and special education needs (SEN) policies, alongside teacher responsibilities in the education of children with SEN in Austria, Hungary, Czech Republic, and Slovakia.

Methods and Procedure: A policy path analysis using a scoping review as an underlying methodological framework was performed.

Outcomes and Results: The end of communism and accession to the European Union were critical for the countries under study. They passed crucial policies after international policies and adopted a three-stream approach towards providing education: (1) special schools; (2) special classes in mainstream schools; or (3) mainstream classes. Special schools remain for children that cannot participate in mainstream schools. Teachers are given high levels of responsibility.
\end{abstract}

Conclusion and Implications: Changes in international guidance greatly impacted Austria, Hungary, Slovakia and the Czech Republic. The education systems aim for inclusion, though segregation remains for children that cannot thrive in mainstream schools. Teachers are pivotal in the education of children with SEN, more so than with typical children.

Keywords: Autism, education, teachers, human rights, policy

\title{
What this paper adds?
}

This paper continues on the policy mapping endeavour to investigate all 28 European Union Member States on their respective autism, education, and special needs policies by investigating Austria, Hungary, Czech Republic, and Slovakia. It specifically scrutinizes the responsibilities allocated to teachers in the education of children with special needs. It also adds to the general understanding of how the values of international guidelines on disability, education, and inclusion are implemented in national policy.

\section{Highlights}

- Special education needs are addressed on a policy level in all four countries

- Teachers play a critical role in SEN education - more so than mainstream education

- Implementation of inclusion practices varies significantly across countries

- Autism-specific policy is scarce and most countries rely on general SEN policy 


\section{Introduction}

Autism refers to neurodevelopmental conditions usually present from early childhood onward that come along with challenges in specific areas such as communication, social interaction, repetitive behaviour, and distinct interests throughout life (Baron-Cohen, 2017). About $1 \%$ of the world population is on the autism spectrum with the sex ratio lying between 3:1 and 4:1 (Charman et al., 2017; Loomes et al., 2017). Over the last decades, autism diagnoses increased steadily. This increase has predominantly been linked to new screening and assessment tools but also to a greater awareness in the general population (Cervantes et al., 2016). In addition to mental health problems, such as anxiety and depression (Croen et al., 2015; Simonoff et al., 2008), other health conditions (e.g. epilepsy, gastrointestinal problems and immune dysregulation) are common comorbidities in autism (Gurney et al., 2006; Lai et al., 2014), making it a significant public health challenge (Newschaffer \& Curran, 2003).

Difficulties in social interaction, including showing empathy and sharing interests and feelings, have a great impact on the quality of life of people with autism (Baron-Cohen, 2017; Billstedt et al., 2011; Lee et al., 2008). One way of improving their quality of life and addressing inequalities they experience is to include them in society as much as possible. One crucial aspect that facilitates equal and inclusive participation in society is the fundamental right to education for people with disabilities (Roleska et al., 2018). This right was first mentioned by the United Nations (UN) in the Universal Declaration of Human Rights (UDHR) but its importance has developed and expanded since then (United Nations, 1948). The Convention on the Rights of the Child (CRC) guarantees the right of children with disabilities to fully and equally participate in society and the right to free and equal education (United Nations, 1989). These rights were later emphasised by the Salamanca Statement (United Nations Educational Social and Cultural Organisation, 1994) and the Convention on the Rights of Persons with Disabilities (CRPD) (Convention on the Rights of Persons with Disabilities, 2006). The CRPD has been ratified by 181 countries, including all 27 European Union (EU) Member States, as well as the United Kingdom (United Nations Department of Economic and Social Affairs, 2020). It ensures the right to inclusive education and lifelong learning. In order to guarantee that people with autism can achieve their full potential in society, adequate lifelong education is paramount (Hehir et al., 2016).

A means to achieve this is through inclusive education (Sumi et al., 2005). Special educational needs (SEN) education used to be provided by either separating children with SEN in special schools or integrating them in the mainstream education facilities (Hehir et 
al., 2016; Norwich, 2002). The ratification of the Salamanca Statement initiated a shift from integrative to inclusive education on a global level. The difference between integrative and inclusive education lies in the perception of diversity. Within an integrative approach, students are schooled in mainstream schools but receive special education and are therefore not an equal member of the school community (Hehir et al., 2016; Norwich, 2002). In contrast, inclusion emphasises the benefits from diversity and relates to the social inclusion of all people in society (Costello \& Boyle, 2013). In order to achieve a change in perception, a societal shift from integrative towards inclusive thinking is necessary (Monsen et al., 2014; Norwich, 2002). Inclusive education is provided in mainstream schools, and while accounting for their individual needs and abilities, students with and without SEN are educated together (Boyle et al., 2013; Lynch \& Irvine, 2009). Both students with SEN and their typical peers benefit from inclusive learning (Eldar et al., 2009; Osborne \& Reed, 2011; Ruijs \& Peetsma, 2009) and inclusive education is especially helpful for children with autism (Harrower \& Dunlap, 2001; Lynch \& Irvine, 2009). However, in order to attain successful inclusive education, the structures of the school and learning environment have to be adapted (Hehir et al., 2016; Norwich, 2002). The CRPD states the need for appropriate teacher education and the provision of support facilities which emphasises its importance (Convention on the Rights of Persons with Disabilities, 2006). In addition, a positive attitude from teachers towards inclusion is indispensable (Boyle et al., 2011; Leatherman \& Niemeyer, 2005), since they have to realize inclusion policies.

Since health and social policy are part of the EU Member States' sovereignty (Treaty on the Functioning of the European Union, 2009), legislation and provision of inclusive education differs considerably across the EU. As such, it is important to identify education policies in the EU in order to ensure inclusive education for every child. The objective of this paper is to contribute to the policy mapping project of the European Consortium for Autism Researchers in Education (EDUCAUS) (EDUCAUS, 2019a), which aims to map all policies relevant for the education of people with autism in all 28 EU Member States (EDUCAUS, 2019b).

This paper maps autism policies of Austria, Hungary, Slovakia and the Czech Republic (henceforth Czech). Moreover, it (1) investigates the interdependences between the current and past international, EU and national policies; (2) identifies critical junctures and patterns in the policy-making process; and (3) analyses the role of teachers within the different autism policies. Aside from expanding the scope of the EDUCAUS policy mapping project, an analysis of these countries is interesting for various reasons. These four 
countries are relatively small (Austria 8,8 million inhabitants; Hungary 9,8 million; Czech 10,6 million; and Slovakia 5,4 million), which creates an interesting contrast when comparing these countries to the analysis of small EU Member States that was done previously (van Kessel et al., n.d.) [in press]. Additionally, the countries under study (apart from Austria, which joined 1995) joined the EU at a later time. Hungary, Slovakia, and Czech were part of the Eastern Bloc countries that adopted communism after World War II and joined the EU in 2004 (European Union, 2019).

It is interesting to compare these four countries because of their common history. The Dual Monarchy Austria-Hungary from 1867 - 1918, which Czech and Slovakia were part of, influences these countries to this day (Deak, 1990). Thus, it is important to analyze the historical and cultural impacts on social and health policy in terms of disability and autism in these countries.

\section{Methods}

The policy mapping framework utilised in this paper is based on the work validated by EDUCAUS previously (Roleska et al., 2018; van Kessel, Roman-Urrestarazu, et al., 2019; van Kessel, Walsh, et al., 2019). More explicitly, the data were gathered through the use of a scoping review (Arksey \& O’Malley, 2005; Levac et al., 2010) and analyzed through a policy path dependence analysis (Mahoney, 2000). Due to there not being a comprehensive data source in the EU on autism and SEN policy, a modular approach to legislative and policy work was adopted to analyse the different educational policy environments (Austrian, Hungarian, Czech, and Slovakian). The findings were reported using the PRISMA framework (Moher et al., 2009).

\section{Eligibility Criteria}

The purposive selection of the countries is based on the needs of the policy mapping project of EDUCAUS. An overview of the eligibility criteria is shown in Table 1. 
Table 1

A Summary of the Eligibility Criteria.

\begin{tabular}{ll}
\hline Criteria & Specification \\
\hline Inclusion & Scope related to the right to education, the national education systems, \\
& disability laws, inclusion, and special education needs. \\
& Aimed at those under 18 years of age. \\
& Documents drafted by a governmental institution. \\
& Publication date after 1948. \\
& Constitutions are included regardless of publication year. \\
& Documents in all languages were considered for inclusion. \\
Exclusion & Policies and actions by non-governmental organisations. \\
\hline
\end{tabular}

\section{Data Collection and Search Strategy}

Like previous work by EDUCAUS (Roleska et al., 2018; van Kessel, RomanUrrestarazu, et al., 2019; van Kessel, Walsh, et al., 2019), the data collection consisted of five steps. This five-step process is depicted in Figure 1. Subsequently, the exact build-up of the search query used for scientific databases is shown in Table 2. The data collection in this study took place between April 2019 and June 2019.

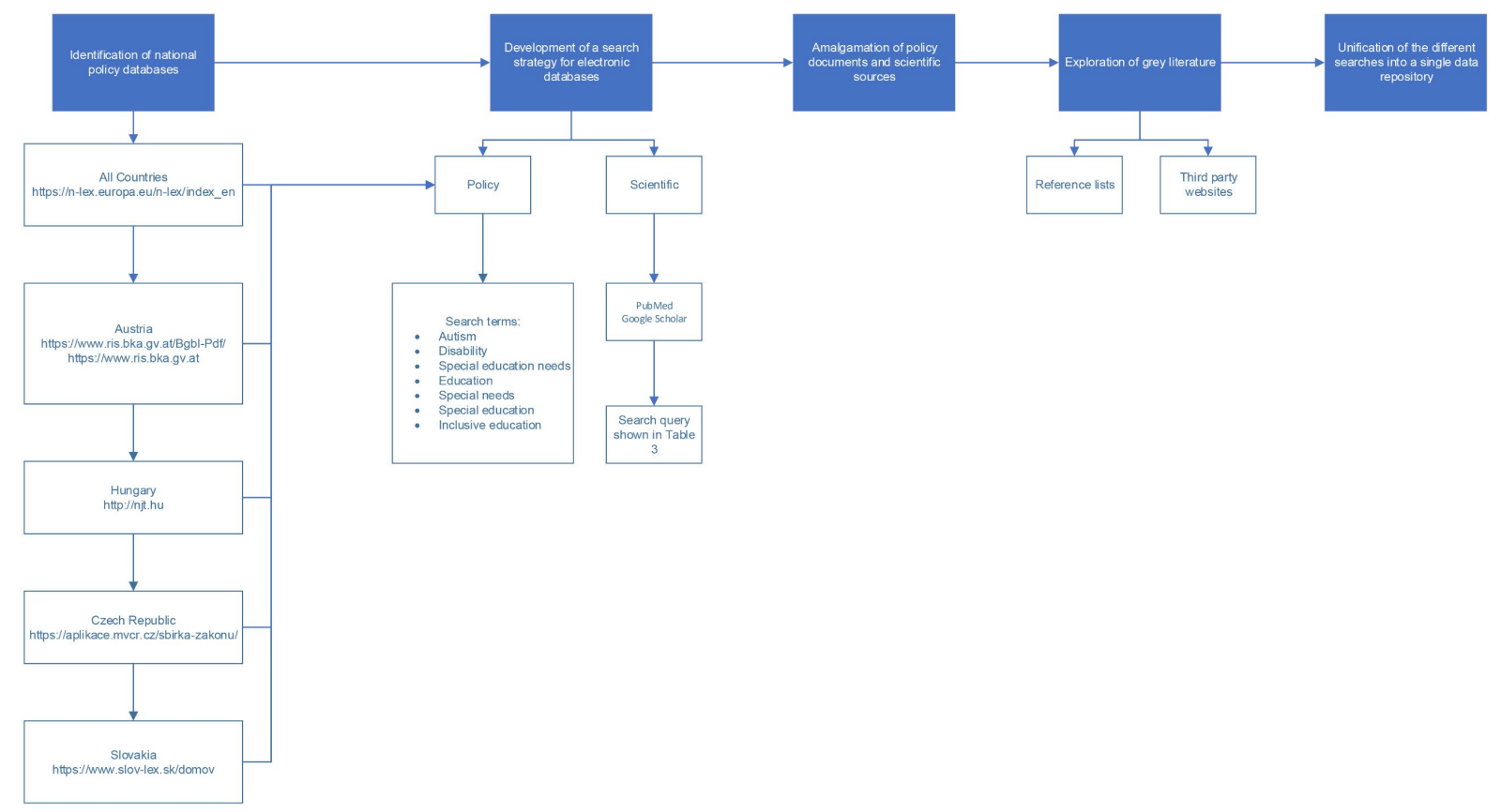

Figure 1. An exact depiction of each step of the data collection process. 
Table 2

The Build-up of the Final Search Query for Academic Databases

\begin{tabular}{ll}
\hline & Search Query \\
\hline S1 & inclusion OR education \\
S2 & $\begin{array}{l}\text { autis* OR ASC OR ASD OR disability OR special educational needs OR SEN } \\
\text { OR disab* } \\
\text { S3 }\end{array} \quad$ policy OR legislation OR regulation OR law \\
S4 & Austria OR Hungary OR (Czech OR Czech Republic) OR Slovakia \\
Final & (inclusion OR education) AND (autis* OR ASC OR ASD OR disability OR \\
& special educational needs OR SEN OR disab*) AND (policy OR legislation OR \\
& regulation OR law) AND (Austria OR Hungary OR (Czech OR Czech Republic) \\
& OR Slovakia) \\
\hline
\end{tabular}

\section{Data Analysis}

After the search strategy was completed, the gathered data was compared to the data that was already gathered on UN and EU policy in the previous work of EDUCAUS (Roleska et al., 2018; van Kessel, Roman-Urrestarazu, et al., 2019; van Kessel, Walsh, et al., 2019). As a result, the extent to which the values of international policies are integrated in the national policies could be established.

To facilitate a comparative analysis, the policies found through the database searches were delineated to the values set out in international documents. This allowed us not only to determine the influence of international guidance on national policy, but also frame the results in a way that the different countries under study can be compared with one another. Four core values are used in the analysis: (1) right to education for all children (UDHR and Salamanca Statement); (2) appropriate/adapted education for children with SEN (Declaration on the Rights of Disabled Persons and the CRPD); (3) appropriate treatment corresponding to the child's condition (Declaration and Convention on the Rights of the Child); and (4) development of inclusive education (CRPD).

\section{Results}

Through the database search for legal governmental documents 3012 sources were identified. After screening for title, 432 documents were included from which 62 were duplicates. After screening the policies, 286 documents were removed from which 22 were 
unreadable documents from Czech. Overall, 84 policy documents were included and fully assessed. Additionally, 321 articles were found through the database searches from PubMed and Web of Science. From these, 24 sources were included after title screening. Eight duplicates were removed. After screening the abstract twelve articles were excluded as they did not meet the scope of this study. All in all, four journal articles were incorporated. Furthermore, eleven documents were detected through reference searches. On the whole, 99 sources were analysed in this study. For a better overview, an adapted PRISMA flowchart illustrates the data collection process in Figure 2. Subsequently, a chronological overview of the included policies per country is shown in Supplementary File 1 and a reference list of the data used is included in Supplementary File 2.

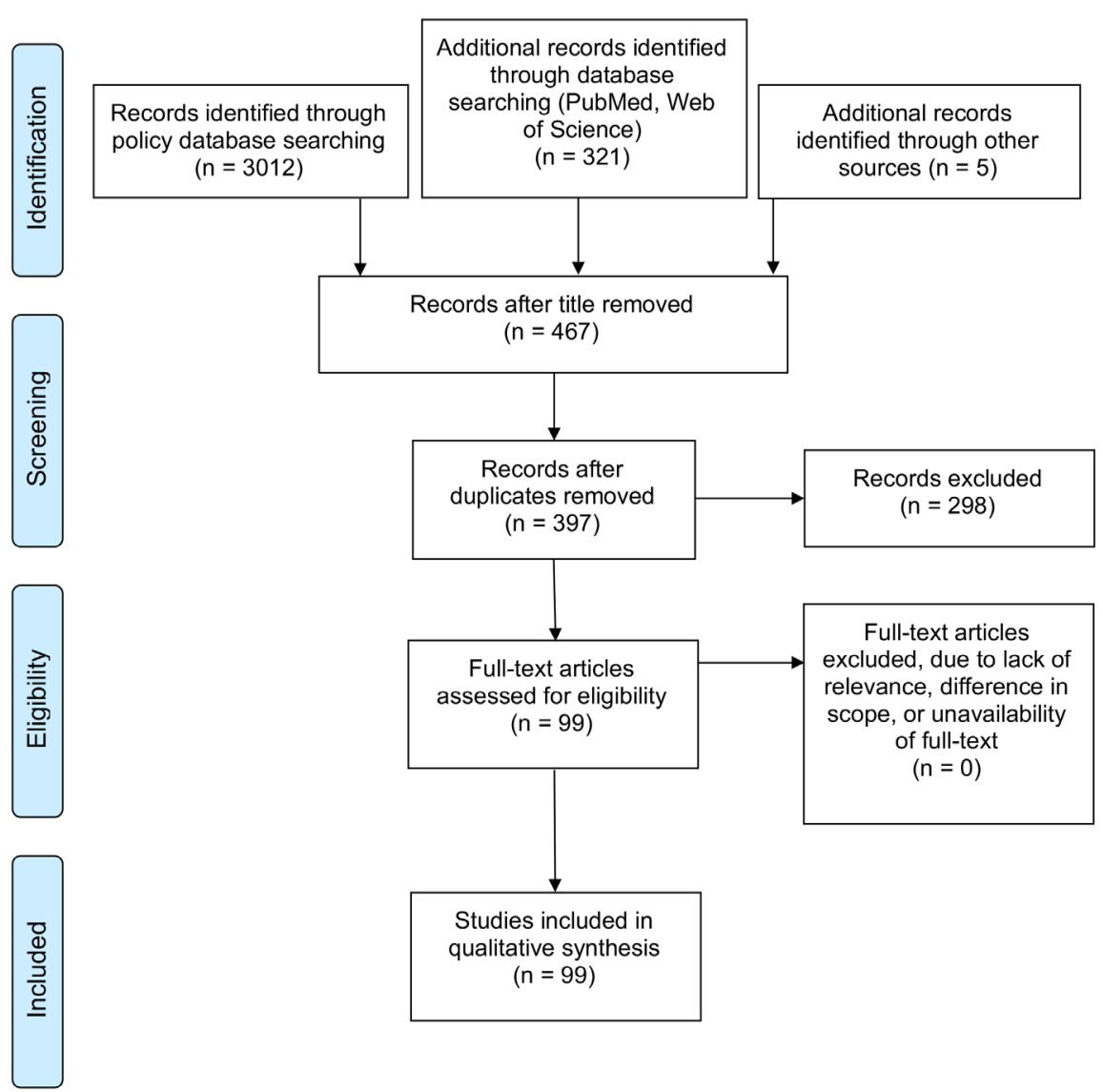

Figure 2. Overview of the data collection process. Author's own compilation based on the PRISMA flowchart.

\section{Austria}

The State Treaty indicated that human rights of all people have to be respected prior to the ratification of the UDHR through the 'Bundesverfassungsgesetz' that implemented the right to education for all children. The adaptation of education for children with SEN is 
reflected in the combination of the 1993 School Organisation Act and the Compulsory Education Act. Appropriate treatment of a child's condition — while never explicitly statedis part of the integration of the Convention on the Rights of the Child in Austrian law. Finally, all policy actions from 2012 onward aim to develop inclusive education as set out in the CRPD.

Austria has no autism-specific policies. However, there are several important policies which address children with SEN. In Austria, education is the responsibility of the state. The federal states are responsible for the provision of education in primary, lower secondary and special schools. Higher secondary and vocational education remains the responsibility of the state (Republic of Austria, 2019).

Aside from that, Austria participates in European projects as 'Mapping the implementation of policy for inclusive education (MIPIE)' and 'Teacher education for inclusion across Europe' that aim to identify what qualitative and quantitative information needs to be gathered for policy makers in order to facilitate the development of policy surrounding inclusion and teacher education, what information is already available, and what gaps in information still exist (European Agency for Special Needs and Inclusive Education, 2019b, 2019c).

In the Directive for the Establishment of Inclusive Model Regions (Republic of Austria, 2015), Kärnten, Tirol, and Steiermark were the three provinces chosen to pioneer the implementation of the CRPD as model regions. The Action Plan to implement the CRPD in Steiermark consists of nine guidelines representing the article of the CRPD and are implemented in three phases (Federal state Steiermark [Austria], 2012, 2015, 2018). To improve inclusive education, 18 measures were developed from which 17 were completely implemented in 2018, including seminars on autism for teachers in general schools. One means to enhance the self-determined living of people with disability is the 'Autism Concept Steiermark'. However, this rather applies to adults as it aims to get a better overview of the support system in order to provide best possible care for people with autism. This measure was realised in 2018 .

Kärnten introduced a Stage Plan to Implement the CRPD 2015 - 2020 which is built on the same guidelines as the Action Plan of Steiermark (Federal state Kärnten [Austria], 2019). Kärnten developed three means to evolve inclusive education. These measures consist of (1) the establishment of two inclusive model regions; (2) the production of a guideline for the promotion of school assistance for children with autism; and (3) the development of small cooperative classes in compulsory education. Since the school year 2014/15 children with 
autism are given effective, personalised support in the general education system. Moreover, a special project which is addressing persons with autism was founded. As there are not enough resources and facilities to care for people with autism to some extent people have to move to other federal states. This has negative consequences as the distance leads to less contact with family and other important social contacts. For this target group, further housing and employment offers in Kärnten are created. A social-therapeutic housing project for children and adolescents has already been implemented, a housing project for adult people which is specifically geared towards their needs is being planned.

The implementation of the inclusive model regions in Tirol is characterised by the development of ten 'Pedagogical Advisory Centres' (Federal state Tirol [Austria], 2016). These centres are responsible for the provision and coordination of special needs education in other types of schools to ensure that children with SEN can be taught in the best possible way in general schools. At the beginning of the school year 2016/2017, pedagogical advisory centres were set up in all educational regions of Tirol. The aim of the measure is to improve the quality of inclusive education and thus to gradually increase inclusive education. In addition, the supervision and support for teachers is improved. In 2014, a monitoring committee was established which, as an independent body, observes the implementation of the CRPD in Tirol (Federal state Tirol [Austria], 2015). In 2018, the Tirol Participation Act came into force (Federal state Tirol [Austria], 2018). The aim of this act is to contribute to the realisation of an inclusive society and to enable people with disabilities to lead a selfdetermined life. Paragraph 9 explicitly mentions educational support services for people with autism. It distinguishes between individual and group support services. Individual support helps to develop cognitive, linguistic, mental, and social skills. Besides, group support assists to train social skills through interaction with other people. This Act is the only legislation in Austria which explicitly addresses people with autism. In 2016, Austria ratified Decree on the Curricula of Primary, Secondary and Special Schools (Republic of Austria, 2016), which expanded the development of inclusive education beyond the three model regions into the rest of Austria.

All three federal states stress in their strategies international (UDHR, CRC, CRPD) and EU (European Disability Strategy 2010-2020) policies and customise their guidelines towards them. In addition, they take the interdependence between national, federal and regional level into account. Even though Austria is a federal republic, the federal states have little power in terms of education policies. However, they decide how to implement national policies. The National Disability Strategy 2012 - 2020 gives them more leeway which is an 
appropriate measure as it is the federal states' responsibility to implement the inclusive education system. Furthermore, it allows identifying best practices to realise inclusion in all over Austria. Apart from Tirol there is not legally binding legislation which is mentioning autism. However, the Austrian education and disability policies mostly cover the SEN of children with autism. As there are strategies to improve the life of people with autism mentioned in the action plans of Steiermark and Kärnten the need of special support becomes apparent which could lead to further legislation. In summary, Austria clearly wants to implement the CRPD and therefore one can assume that more policies to realise an inclusive society will be passed.

\section{Hungary}

The right to education for all children in Hungarian law through the Convention on the Rights of the Child - a direct implementation from the international document - and the Public Education Act. The latter also addressed the adaptation of education for children with SEN and the possibility to be educated in special schools, special classes in mainstream schools, or general classes, on top of establishing the necessity for appropriate treatment that corresponds to the child's condition. Elements of inclusion have been in place since the Public Education Act. More recently_policies from 2005 onward - there has been a larger focus on the development of inclusive education.

According to the European Agency for Special Needs and Inclusive Education, Hungary introduced a postgraduate specialist training course on 'Autism spectrum disorder pedagogy' in 2009 (European Agency for Special Needs and Inclusive Education, 2019a). In addition, Hungary was the first country in Europe which offered since the academic year 2012/13 bachelor's degree students to pursue an autism pedagogy specialisation course. In short, one can say that Hungary follows a progressive disability strategy. Even though it does not clearly distinguish between integrative and inclusive education, Hungary always followed an integrative education path. None of the Public Education Acts mentioned that children with SEN have to be educated in special schools or classes. Instead, children always had the right to be educated in general schools. Finally, Hungary is also listed as a contributor to the MIPIE project (European Agency for Special Needs and Inclusive Education, 2019b).

\section{Czechoslovakia (until 1990)}

Before mapping the respective policies of Slovakia and Czech, it is necessary to briefly explain their common history and establish policies from the former Czechoslovakia 
(Stolarik, 2016). After the decomposition of Austro-Hungarian Empire after the First World War, the First Czechoslovak Republic (1918-1939) as a unified state was founded (Miškolci, 2016). Even though it passed its own education policies, it took over the centralised public administration system of the Austro-Hungarian Monarchy and the authority about education laid with the state (Hoetzel \& Joachim, 1920). With the exception of Subcarpathian Ruthenia, pre-war Czechoslovakia was re-established after the Second World War. Decades later, after Czechoslovakia was split into its constituent countries (Czech and Slovakia), they joined the EU in 2004 (European Union, 2019).

The right to education was part of the Constitution of Czechoslovakia and thus immediately implemented upon ratification. The Decree on Education Counselling infers that educational approaches could be adapted by stating that children with SEN and educational staff could be counselled. Regardless, the adaptation of education was not explicitly stated until the implementation of the Education Act-which also addressed the fact that a child's condition should be appropriately treated in-classrooms so the child could develop itself optimally. Inclusion, even though mentioned, referred to the uptake of children with SEN in mainstream classes and providing additional support out-of-class, thus referring to the dimension of integration of the UN model (Hehir et al., 2016).

\section{Czech Republic.}

Following the separation of Czechoslovakia into Czech and Slovakia, each country started to further develop their education system. In Czech, this resulted in the implementation of policies that were founded on the values of international policies and guidelines. As a result, an education system that fosters inclusion where possible was developed.

By implementing the Convention on the Rights of the Child in Czech law, the right to education for all children remained ensured after the division of Czech and Slovakia. This right was further emphasized by the Education Act, along with the value on appropriate treatment of a child's condition and adaptation of education for children with SEN. Inclusion practices are being developed since 2005. Finally, Czech is listed as one of the contributors to the MIPIE project (European Agency for Special Needs and Inclusive Education, 2019b).

\section{Slovakia.}

The translation of the Convention on the Rights of the Child ensured the continuation of the right to education for all children in Slovakia after its separation. The Education Act 
reinforced this right and subsequently established adaptations to the education environment to facilitate children with SEN. Appropriate treatment corresponding to the child's condition is inferred in the Education Act given its focus to deliver education "according to the needs and capacities of the child." Finally, the development of inclusive education started with the implementation of the CRPD and the 2014 Strategy, though it remains in its infancy. Notably, Slovakia currently has no policy in place to implement the values set out in the CRPD specifically.

\section{Discussion}

In line with previous research done in the policy mapping project of EDUCAUS, the UDHR was a critical juncture for the four countries under study - though the end of the communist era was too. It changed the political system in Hungary, Czech and Slovakia completely, creating democratic republics. The end of communism in Europe also led to a new dynamic in European integration. Austria joined the EU in 1995, Hungary, Czech and Slovakia in 2004 (European Union, 2019). In terms of education, the Salamanca Statement, CRC, CRPD, and European Disability Strategy 2010-2020 significantly impacted national policy-making and value systems. Especially the CRC and the Salamanca Statement facilitated the shift from an integrative to an inclusive perspective. This paper also investigated teacher-related policies and found that teachers are assigned great responsibilities through national policies, though how teacher education and additional assistance for teachers are regulated differs per country.

All four countries passed important education policies after the ratification of the $\mathrm{CRC}$ and the Salamanca Statement. The first legally binding legislation for inclusive education in Austria was the 1993 School Organisation Act. In 2012, Austria published the National Action Plan on Disability 2012-2020, aimed to implement the CRPD and European Disability Strategy 2010-2020. The disability strategies from Tirol, Kärnten, and Steiermark also mention the CRPD and the European Disability Strategy 2010-2020. Hungary manifested inclusive education with the Public Education Act and all legislation firmly reassured the rights of the child-indicating the impact of the CRC. After Hungary joined the EU, the Directive on SEN was passed which is key for SEN education - particularly autism. Hungary also amended the Directive on SEN according to the CRPD, while the Hungarian National Disability Programme 2015-2025 is based on the CRPD and the European Disability Strategy 2010-2020. Compared to other EU countries, Czech and Slovakia passed respective education legislation late. Czech passed the Education Act in 2004 and Slovakia in 
2008. This was partially due to the political changes in the value and economical system after the dissolution of Czechoslovakia. The importance of the EU accession for both countries shows in their Education Acts. Both emphasised that a fundamental principle of education is the knowledge and understanding of European values, traditions, and principles resulting from European integration. Slovakia enabled children to receive inclusive education in its Education Act, though the 2003 Decree on Special Schools already introduced inclusive language. Czech ratified the CRPD and passed the Act on Implementing EU Legislation in 2009-found in the National Plan for the Creation of Equal Opportunities for Persons with Disabilities 2010-2014. In 2014, the Education Act finally established the right to inclusive education for children with SEN. Czech continues to improve its inclusive education system, publishing the National Plan for the Creation of Equal Opportunities for Persons with Disabilities 2015-2020 to implement the CRPD further.

The education policies in the countries under study were not only in line with the values set out in key UN documents, such as the UDHR, CRC, and CRPD, but also adopted specific points set out by the Council of Europe on the education and social inclusion of children with autism (Council of Europe, 2009). All countries under study adopted legislation and policies that facilitated social integration, promoted the development and independence of children with autism, and prohibit discrimination on the basis of disability. They also provided a legal framework that ensures the rights of children with autism to receive education in mainstream education where possible. Specific training programs for teachers are found in Hungary, whereas Austria, Czech, and Slovakia only assert that teachers are required to participate in life-long learning to maintain and develop their competences in working with children with disabilities, including autism.

All four countries guarantee equality of people and the fundamental right to equal and free education for all in their constitutions. For education policies, it can be noted that all countries have a three-stream approach towards education for children with SEN. They can attend special schools (segregation), special classes in mainstream schools (integration), or mainstream classrooms (inclusion). Even though the aim is an inclusive school system, special schools for children that cannot participate in mainstream education are retained. Hungary underlined that children with SEN should be happy in inclusive education. In all four countries, schools should provide children with SEN with education resources, facilities, and materials appropriate to their condition.

Of the four reviewed countries, Hungary has the most progressive autism-specific education policies. The Decrees from 2005 and 2012 on Special Needs Education for Pupils 
provide detailed rules for the education of children with autism and acknowledge autism as a condition - not only as a medical disorder. They are entitled to various support measures to achieve successful education and development. The Slovakian Education Act states that schools have to follow an education programme for children with autism which is part of the national education programme. On a federal level, Austria has no national autism-specific policies, though inclusion policies are also applicable for children with autism. The three established model regions for inclusive education, Kärnten, Steiermark and Tirol all developed autism-specific strategies that go beyond education into general challenges, general support, facilities, and housing to improve the quality of life of people with autism as a whole (Federal state Kärnten [Austria], 2019; Federal state Steiermark [Austria], 2018; Federal state Tirol [Austria], 2018). Tirol is the only federal state in Austria which has autism-specific legislation (Federal state Tirol [Austria], 2018). Even though Czech policies do not address autism specifically, they still apply to children with autism.

Teachers have tremendous responsibilities in the reviewed countries-even more so for children with SEN. Overall, the rights and duties of the educational staff are very similar in all countries. During the communist era, teachers were obliged to follow its ideology in Hungary, Czech, and Slovakia. The fall of this regime highlights the change of the value system. As recommend (Boyle et al., 2011), all four countries introduced counselling and support facilities to support their educational staff. Since the 2008 Education Act, teachers in Slovakia need to follow specific education programmes for children with SEN. Mainstream schools that educate children with SEN have to employ teachers specialised in special needs education and school psychologists. Czech established advisory services that develop appropriate support tools and provide methodological support for teachers in schools. In Hungary, education staff are assisted, consulted and trained by expert groups (Republic of Hungary, 2011). Austrian pedagogical services responsible for supporting and supervising teachers were also established (Republic of Austria, 2017). In terms of training, teachers have the right and obligation to further education in all four countries. In addition to the provision of training for SEN education, Hungary also offers further training on education for students with autism (European Agency for Special Needs and Inclusive Education, 2019a). Although a positive attitude of teachers towards inclusion is key, it is not addressed in the education policies yet (Boyle et al., 2011; Leatherman \& Niemeyer, 2005).

Austria has emerged as the most progressive country in this analysis in terms of implementation of the CRPD and inclusion. Austria examines how people with disabilities can be admitted as teachers and how teacher training has to be adapted. Thus, four years after 
the ratification of the CRPD Austria does not question whether an inclusive school system shall be established but how it can be built best. In contrast, Slovakia has yet to implement a general inclusion strategy, though this could also be a consequence of the costs paired with changing policy paths as establishing inclusion is linked with many costs (Norwich, 2002). This would also serve as explanation as to why Slovakia is the only country under study to not contribute to the MIPIE project. Hungary has the most autism-specific education policies, though the extent of their implementation is worth an analysis of its own. Czech, Hungary, and Slovakia have a relatively large Roma community which might not benefit from these inclusion policies (Brüggemann, 2012; Messing, 2017; Rostas \& Kostka, 2014). Furthermore, Hungary currently undergoes a continuous trend of a decreasing democracy (Szikra, 2014) and is only on the global democracy rank 55. Czech and Slovakia are also considered flawed democracies, though both countries have a higher global democracy rank (Czech 32, Slovakia 42) (Economist Intelligence Unit, 2020). The question remains how far policies are actually implemented.

Findings of this paper also support the results of a previous EDUCAUS study, in which the effects of international guidance on small states in the EU was explored (van Kessel et al., n.d.) [in press]. In this study, Slovakia fits their description of small states, which are "states that not only have a small population size, but also are not in a position to influence the international policy environment on their own and are, by extension, largely dependent on the decisions of larger states and overarching political structures." They state that, even though tension can arise in the field of health policy, this is not the case in education policy. In education policy, guidelines that are set out in internationally are translated to national policy with minimal tension, if any at all. The findings of this paper further support this claim, as the values set out by international guidance (e.g. the UDHR, $\mathrm{CRC}$, and CRPD) have been translated directly to national policy of small and large EU Member States alike.

This study has several limitations. In general, a high risk of scoping reviews is a researcher bias (Anderson et al., 2008; Morse, 2015). Within this study, there is a risk of researcher bias because the mother tongues of one of the lead authors is German. Austrian policies may be analysed in a more detailed way than policies from Czech, Hungary and Slovakia. However, since the other lead author's mother tongue is Dutch, this functioned as a safeguard for asymmetrical analyses of Austrian policies compared to other countries. To counteract this further, country experts from Hungary and Slovakia reviewed the results of their respective countries. An expert of Czech could not be found, which may impact the 
completeness of Czech policy data. Furthermore, as the method of this study was a scoping review, the results cannot be generalised across Europe. That being said, it is still possible to identify good practices highlighted in the countries under study and translate that to another setting after accounting for policy and cultural environments, among others. Another limitation of this paper is the translation of both the key phrases from English to Hungarian, Czech, and Slovakian respectively and the Hungarian, Czech, and Slovakian policy texts into English. For the initial translation of these documents, online translators were used. However, these are not always accurate and could have led to important legislation being missed or policy texts being misinterpreted. To mitigate this limitation, country experts verified the completeness and correctness of the policy data, leaving only the Czech data at risk of this limitation. As for the analysis of inclusion policies, the specific semantic meaning of "inclusion" is of high importance, thus translation carries a risk. Furthermore, it cannot be guaranteed that all important legislations have been identified. Moreover, all databases were electronic databases. Some policy documents might not have been digitalised and are missing in this data collection. Finally, this paper only analysed primary and secondary education policies for children with SEN. However, tertiary education policies are also very important for the equal access to education. Thus, this paper only contributes to the analysis of the education of children and does not give an overall picture of the education policies for persons with SEN.

Ultimately, by mapping policies which are relevant for children with SEN in Austria, Hungary, Czech and Slovakia this study provides important information about the access to education for children with autism. It becomes evident that all four reviewed countries have adequate SEN policies in force. However, there are disparities in the level of policy development between the four countries. Austria has the most progressive policies to implement the CRPD. Hungary and Czech also have effective strategies in place. Slovakia, on the other hand, still lacks strategies for implementing the CRPD. Critical junctures not only influenced the paths of policy-making but also changed the perception of disability and autism.

\section{References}

Anderson, S., Allen, P., Peckham, S., \& Goodwin, N. (2008). Asking the right questions: Scoping studies in the commissioning of research on the organisation and delivery of health services. Health Research Policy and Systems, 6, 1-12.

https://doi.org/10.1186/1478-4505-6-7 
Arksey, H., \& O’Malley, L. (2005). Scoping studies: towards a methodological framework. International Journal of Social Research Methodology, 8(1), 19-32. https://doi.org/10.1080/1364557032000119616

Baron-Cohen, S. (2017). Editorial Perspective: Neurodiversity-a revolutionary concept for autism and psychiatry. https://doi.org/10.1111/jcpp.12703

Billstedt, E., Gillberg, C., \& Gillberg, C. (2011). Aspects of quality of life in adults diagnosed with autism in childhood: A population-based study. Autism, 15(1), 7-20. https://doi.org/10.1177/1362361309346066

Boyle, C., Scriven, B., Durning, S., \& Downes, C. (2011). Facilitating the learning of all students: The "professional positive" of inclusive practice in Australian primary schools. Support for Learning, 26(2), 72-78. https://doi.org/10.1111/j.1467-9604.2011.01480.x

Boyle, C., Topping, K., \& Jindal-Snape, D. (2013). Teachers' attitudes towards inclusion in high schools. Teachers and Teaching, 19(5), 527-542. https://doi.org/10.1080/13540602.2013.827361

Brüggemann, C. (2012). Policy brief: Roma education in comparative perspective. Analysis of the UNDP/World Bank/EC.

Cervantes, P. E., Matson, J. L., \& Goldin, R. L. (2016). Diagnosing ASD in Very Early Childhood (pp. 157-173). https://doi.org/10.1007/978-3-319-27171-2_9

Charman, T., Loth, E., Tillmann, J., Crawley, D., Wooldridge, C., Goyard, D., Ahmad, J., Auyeung, B., Ambrosino, S., Banaschewski, T., Baron-Cohen, S., Baumeister, S., Beckmann, C., Bölte, S., Bourgeron, T., Bours, C., Brammer, M., Brandeis, D., Brogna, C., ... Buitelaar, J. K. (2017). The EU-AIMS Longitudinal European Autism Project (LEAP): clinical characterisation. Molecular Autism, 8(1), 27. https://doi.org/10.1186/s13229-017-0145-9

Costello, S., \& Boyle, C. (2013). Pre-service Secondary Teachers’ Attitudes Towards Inclusive Education. Australian Journal of Teacher Education, 38(4). https://doi.org/10.14221/ajte.2013v38n4.8

Council of Europe. (2009). Recommendation CM/Rec(2009)9 of the Committee of Ministers to member states on the education and social inclusion of children and young people with autism spectrum disorders.

https://search.coe.int/cm/Pages/result_details.aspx?ObjectID=09000016805d046f

Croen, L. A., Zerbo, O., Qian, Y., Massolo, M. L., Rich, S., Sidney, S., \& Kripke, C. (2015). The health status of adults on the autism spectrum. Autism, 19(7), 814-823. https://doi.org/10.1177/1362361315577517 
Deak, I. (1990). Beyond Nationalism: A Social and Political History of the Habsburg Officer ... - Istvan Deak - Google Books.

Economist Intelligence Unit. (2020). Democracy Index 2019: A year of democratic setbacks and popular protest.

https://www.eiu.com/Handlers/WhitepaperHandler.ashx?fi=Democracy-Index2019.pdf\&mode $=$ wp\&campaignid $=$ democracyindex 2019

EDUCAUS. (2019a). European Consortium for Autism Researchers in Education. https://www.educaus.eu/

EDUCAUS. (2019b). Objectives and Coverage. https://www.educaus.eu/objectives-andcoverage.html

Eldar, E., Talmor, R., \& Wolf-Zukerman, T. (2009). International Journal of Inclusive Education Successes and difficulties in the individual inclusion of children with Autism Spectrum Disorder (ASD) in the eyes of their coordinators. International Journal of Inclusive Education, 14(1), 97-114. https://doi.org/10.1080/13603110802504150

European Agency for Special Needs and Inclusive Education. (2019a). Country information for Hungary: Teacher education for inclusive education.

European Agency for Special Needs and Inclusive Education. (2019b). Mapping the Implementation of Policy for Inclusive Education.

European Agency for Special Needs and Inclusive Education. (2019c). Teacher Education for Inclusion Across Europe - Challenges and Opportunities.

Treaty on the Functioning of the European Union, (2009). http://eur-lex.europa.eu/legalcontent/EN/TXT/PDF/?uri=CELEX:12012E/TXT

European Union. (2019). The History of the European Union.

Federal state Kärnten [Austria]. (2019). Landesetappenplan 2014 - 2020.

Federal state Steiermark [Austria]. (2012). Umsetzung der UN-Behindertenrechtskonvention. Aktionsplan des Landes Steiermark. Phase 1: 2012-2014.

Federal state Steiermark [Austria]. (2015). Umsetzung der UN-Behindertenrechtskonvention. Aktionsplan des Landes Steiermark. Phase 2: 2015-2017.

Federal state Steiermark [Austria]. (2018). Umsetzung der UN-Behindertenrechtskonvention. Aktionsplan des Landes Steiermark. Phase 3: 2018-2012.

Federal state Tirol [Austria]. (2015). Inklusive Bildung in Tirol. Eine Stellungnahme des Tiroler Monitoringausschusses zur Überwachung der UN-Konvention über die Rechte von Menschen mit Behinderungen.

Federal state Tirol [Austria]. (2016). Pädagogische Beratungszentren: PBZ. Modell Tirol. 
Federal state Tirol [Austria]. (2018). Tiroler Teilhabegesetz (32/2018).

Gurney, J. G., Mcpheeters, M. L., \& Davis, M. (2006). Parental Report of Health Conditions and Health Care Use Among Children With and Without Autism Article in Archives of Pediatrics and Adolescent Medicine · Child Care Center Illness Policies View project Outcomes and Survivorship in Childhood Cancer View . https://doi.org/10.1001/archpedi.160.8.825

Harrower, J. K., \& Dunlap, G. (2001). Children with autism can benefit from participation in inclusive classroom environments Including Children With Autism in General Education Classrooms A Review of Effective Strategies. Dunlap / CLASSROOM INCLUSION.

Hehir, T., Grindal, T., Freeman, B., Lamoreau, R., Borquaye, Y., \& Burke, S. (2016). A summary of the evidence on inclusive education.

Hoetzel, J., \& Joachim, V. (1920). The Constitution of the Czechoslovak Republic.

Lai, M.-C., Lombardo, M. V, \& Baron-Cohen, S. (2014). Autism. Lancet, 383(9920), 896910. https://doi.org/10.1016/s0140-6736(13)61539-1

Leatherman, J. M., \& Niemeyer, J. A. (2005). Teachers' Attitudes Toward Inclusion: Factors Influencing Classroom Practice. Journal of Early Childhood Teacher Education, 26(1), 23-36. https://doi.org/10.1080/10901020590918979

Lee, L.-C., Harrington, R. A., Louie, B. B., \& Newschaffer, C. J. (2008). Children with Autism: Quality of Life and Parental Concerns. Journal of Autism and Developmental Disorders, 38(6), 1147-1160. https://doi.org/10.1007/s10803-007-0491-0

Levac, D., Colquhoun, H., \& O’Brien, K. K. (2010). Scoping studies: advancing the methodology. Implementation Science, 5(1), 69. https://doi.org/10.1186/1748-5908-5-69

Loomes, R., Hull, L., \& Mandy, W. P. L. (2017). What Is the Male-to-Female Ratio in Autism Spectrum Disorder? A Systematic Review and Meta-Analysis. Journal of the American Academy of Child and Adolescent Psychiatry, 56(6), 466-474. https://doi.org/10.1016/j.jaac.2017.03.013

Lynch, S. L., \& Irvine, A. N. (2009). Inclusive education and best practice for children with autism spectrum disorder: An integrated approach. International Journal of Inclusive Education, 13(8), 845-859. https://doi.org/10.1080/13603110802475518

Mahoney, J. (2000). Path dependence in historical sociology. Theory and Society, 29(4), $507-548$.

http://webarchiv.ethz.ch/soms/teaching/OppFall09/MahoneyPathDependence.pdf Messing, V. (2017). Differentiation in the making: Consequences of school segregation of Roma in the Czech republic, Hungary, and Slovakia. European Education, 49(1), 89- 
103. https://doi.org/10.1080/10564934.2017.1280336

Miškolci, J. (2016). Inclusive education in the Slovak Republic two decades after the dissolution of Czechoslovakia. International Journal of Inclusive Education, 20(2), 199-213. https://doi.org/10.1080/13603116.2015.1079272

Moher, D., Liberati, A., Tetzlaff, J., Altman, D. G., \& PRISMA Group. (2009). Preferred reporting items for systematic reviews and meta-analyses: the PRISMA statement. BMJ (Clinical Research Ed.), 339, b2535. https://doi.org/10.1136/BMJ.B2535

Monsen, J. J., Ewing, D. L., \& Kwoka, M. (2014). Teachers' attitudes towards inclusion, perceived adequacy of support and classroom learning environment. Learning Environments Research, 17(1), 113-126. https://doi.org/10.1007/s10984-013-9144-8

Morse, J. M. (2015). Critical Analysis of Strategies for Determining Rigor in Qualitative Inquiry. Qualitative Health Research, 25(9), 1212-1222. https://doi.org/10.1177/1049732315588501

Newschaffer, C. J., \& Curran, L. K. (2003). Autism: An Emerging Public Health Problem. In Public Health Reports (Vol. 118).

Norwich, B. (2002). Education, Inclusion and Individual Differences: Recognising and Resolving Dilemmas. British Journal of Educational Studies, 50(4), 482. https://doi.org/10.1111/1467-8527.t01-1-00215

Osborne, L. A., \& Reed, P. (2011). School factors associated with mainstream progress in secondary education for included pupils with Autism Spectrum Disorders. Research in Autism Spectrum Disorders, 5(3), 1253-1263. https://doi.org/10.1016/j.rasd.2011.01.016

Republic of Austria. (2015). Verbindliche Richtlinie zur Entwicklung von Inklusiven Modellregionen (17/2015).

Republic of Austria. (2016). 219. Änderung der Verordnung über die Lehrpläne der allgemein bildenden höheren Schulen.

Republic of Austria. (2017). Bildungsreformgesetz 2017 (138/2017).

Republic of Austria. (2019). Bundes-Verfassungsgesetz (B-VG).

Republic of Hungary. (2011). 2011. évi CXC. törvény a nemzeti köznevelésröl.

Roleska, M., Roman-Urrestarazu, A., Griffiths, S., Ruigrok, A. N. V., Holt, R., van Kessel, R., McColl, K., Sherlaw, W., Brayne, C., \& Czabanowska, K. (2018). Autism and the right to education in the EU: Policy mapping and scoping review of the United Kingdom, France, Poland and Spain. PLOS ONE, 13(8), e0202336. https://doi.org/10.1371/journal.pone.0202336 
Rostas, I., \& Kostka, J. (2014). Structural Dimensions of Roma School Desegregation Policies in Central and Eastern Europe. European Educational Research Journal, 13(3), 268-281. https://doi.org/10.2304/eerj.2014.13.3.268

Ruijs, N. M., \& Peetsma, T. T. D. (2009). Effects of inclusion on students with and without special educational needs reviewed. Educational Research Review, 4(2), 67-79. https://doi.org/10.1016/j.edurev.2009.02.002

Simonoff, E., Pickles, A., Charman, T., Chandler, S., Loucas, T., \& Baird, G. (2008). Psychiatric Disorders in Children With Autism Spectrum Disorders: Prevalence, Comorbidity, and Associated Factors in a Population-Derived Sample. Journal of the American Academy of Child \& Adolescent Psychiatry, 47(8), 921-929. https://doi.org/10.1097/CHI.0B013E318179964F

Stolarik, M. M. (2016). The Czech and Slovak Republics: Twenty Years of Independence, 1993-2013. Central European University Press.

Sumi, C., Marder, C., \& Wagner, M. (2005). The Social Adjustment of Elementary and Middle School Students with Disabilities. https://seels.sri.com/designdocs/engagement/05_SEELS_outcomes_C5_10-3-05.pdf

Szikra, D. (2014). Democracy and welfare in hard times: The social policy of the Orbán Government in Hungary between 2010 and 2014. Journal of European Social Policy, 24(5), 486-500. https://doi.org/10.1177/0958928714545446

United Nations. (1948). Universal Declaration of Human Rights | United Nations.

United Nations. (1989). Convention on the Rights of the Child. http://www.ohchr.org/Documents/ProfessionalInterest/crc.pdf

Convention on the Rights of Persons with Disabilities, (2006). http://www.ohchr.org/EN/HRBodies/CRPD/Pages/ConventionRightsPersonsWithDisabi lities.aspx\#3

United Nations Department of Economic and Social Affairs. (2020). Convention on the Rights of Persons with Disabilities (CRPD).

https://www.un.org/development/desa/disabilities/convention-on-the-rights-of-personswith-disabilities.html

United Nations Educational Social and Cultural Organisation. (1994). The Salamanca Statement and Framework for Action. Policy, June, 7-10.

van Kessel, R., Hrzic, R., Czabanowska, K., Baranger, A., Azzopardi-Muscat, N., Charambalous-Darden, N., Brayne, C., Baron-Cohen, S., \& Roman-Urrestarazu, A. (n.d.). Autism and the Influence of International Legislation on Small EU Member 
States: Policy Mapping in Malta, Cyprus, Luxembourg, and Slovenia.

van Kessel, R., Roman-Urrestarazu, A., Ruigrok, A., Holt, R., Commers, M., Hoekstra, R.

A., Czabanowska, K., Brayne, C., \& Baron-Cohen, S. (2019). Autism and family

involvement in the right to education in the EU: policy mapping in the Netherlands,

Belgium and Germany. Molecular Autism, 10(1). https://doi.org/10.1186/s13229-019-

0297-x

van Kessel, R., Walsh, S., Ruigrok, A. N. V., Holt, R., Yliherva, A., Kärnä, E., Moilanen, I.,

Hjörne, E., Johansson, S. T., Schendel, D., Pedersen, L., Jørgensen, M., Brayne, C.,

Baron-Cohen, S., \& Roman-Urrestarazu, A. (2019). Autism and the right to education in the EU: policy mapping and scoping review of Nordic countries Denmark, Finland, and

Sweden. Molecular Autism, 10(1). https://doi.org/10.1186/s13229-019-0290-4

\section{Supplementary File 1}

\section{Supplementary Material}

\begin{tabular}{|c|c|c|c|}
\hline Country & Year & Policy & Characteristics \\
\hline \multirow[t]{13}{*}{ Austria } & 1945 & $\begin{array}{c}\text { Federal Conslitutional Law } \\
\end{array}$ & Austria is a democralic federal republic; emphasised the equality anong people \\
\hline & 1955 & State Treaty & Austria became an independent statc; laid down the foundation of human rights; human rights of all people have to be respected \\
\hline & 1964 & Bundesverfassungsgesetz & Ratification of the Universal Declaration of Iluman Rights in Austria \\
\hline & 1975 & School Organisation Acl & $\begin{array}{l}\text { As part of general compulsory education, integraled primary schools are implemented-which refer to partial joint education of children with } \\
\text { and without SEN }\end{array}$ \\
\hline & 1992 & Convention on the Rights of the Child & Ratification of the Convention on the Rights of the Child in Austria \\
\hline & 1993 & School Organisation Act & Introduced special needs education centres; main lasks were to provide and coordinale special education services in mainstream education \\
\hline & 1993 & Compulsory Lducation Act & $\begin{array}{l}\text { Limphasised the right to joint education; school-age children with SLN are entitled to complete compulsory schooling in mainstream or } \\
\text { special education }\end{array}$ \\
\hline & 1996 & Modification of the 1993 School Organisation $\Lambda$ ct & Children with SEN were allowed to visit the general lower sccondary education school if they successfully completed primary school \\
\hline & 2005 & Lederal Disability Liquality Act & Guarantees the equal participation of persons with disabilities in society \\
\hline & 2012 & $\begin{array}{l}\text { National Action Plan Disability } 2012-2020 \\
\end{array}$ & $\begin{array}{l}\text { Identified means to improve and achieve inclusive education, such as establishing model regions for inclusive education, increasing school } \\
\text { experiments in higher secondary schools, enhancing integrative school classes, increasing further training for teachers and further } \\
\text { development of this training, and generating inclusive teaching resources }\end{array}$ \\
\hline & 2015 & Directive for the Establishment of Inclusive Model Regions & 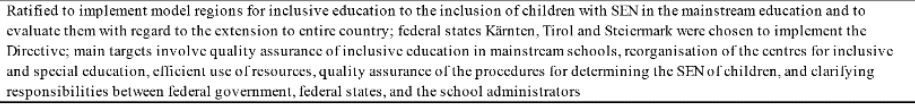 \\
\hline & 2016 & $\begin{array}{l}\text { Decree on the Curricula of Primary, Secondary and Special } \\
\text { Schools }\end{array}$ & $\begin{array}{l}\text { Changed the focus of education from integration to inclusion; key aspects to achieve are individualized and social learning; schools are } \\
\text { responsible for optimal development of children; school have to offer differentiated learning, respond to individual needs, consider diverse } \\
\text { necds of carc, devclop fectback procecdures, and crcate a good and stimulating learning climate }\end{array}$ \\
\hline & 2017 & Education Reform Act & $\begin{array}{l}\text { Schools and teachers have more freedom in shaping their education; group and class sizes can be adjusted; resources can be used more } \\
\text { flexibly; duration of periods can be adapted-while total teaching time remains unchanged; schools can merge into clusters -strengthening } \\
\text { cooperation; in-house teacher training is expanded }\end{array}$ \\
\hline \multirow[t]{7}{*}{$\begin{array}{l}\text { Hungary } \\
\end{array}$} & 1989 & Hungarian Constitution & Determined the protection of inviolable human rights \\
\hline & 1991 & Convention on the Rights of the Child & Implementation of the international document \\
\hline & 1993 & Public Education Act & $\begin{array}{l}\text { Guaranted the right for education based on equal opportunities; children have the right to be educated in a safe and heal thy environment, } \\
\text { and to receive education according to their personal needs, condition and abilities; children with SEN could attend special schools, special } \\
\text { classes in mainstream schools or in mainstream classes; repealed in } 2016\end{array}$ \\
\hline & 1998 & $\begin{array}{l}\text { Act on the Rights and Liqual Opportunities of Persons with } \\
\text { Disabilities }\end{array}$ & $\begin{array}{l}\text { People with disabilities are equal members of society with equal dignity; children with SLN have the right to attend early development } \\
\text { education according to their needs; if advantageous, children with SEN can be educated in general kindergartens and schools; choice of } \\
\text { school for children with SEN } \text { sis with the parents based on the opinion of the expert and rehabilitation committees; established the National } \\
\text { Disability Council which assists to carry out tasks relatcd to disability matters }\end{array}$ \\
\hline & 2005 & Directive on Special Needs Education for Pupils & 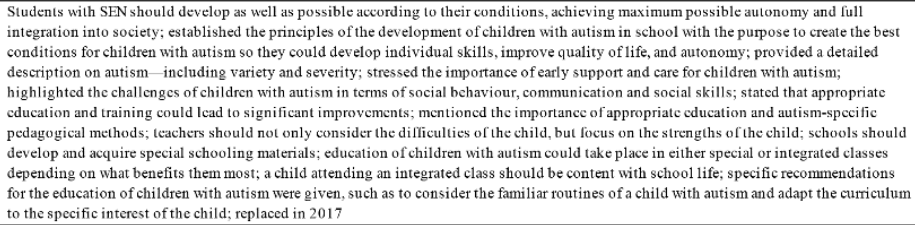 \\
\hline & 2007 & Convention on Rights of Persons with Disabilities & Implementation of the international document \\
\hline & $\overline{2012}$ & Hungarian Constitution & $\begin{array}{l}\text { Fstablishcs the cquality of all pcople and grants cach person fundamcntal human rights without discrimination on disability among other } \\
\text { things; cvery child has the rightt to cnjoy the care and protection by family, statc, and socicly - which is necessary for physical, mental, and } \\
\text { moral development; every Hungarian citizen have the right to education that is ensured by extending and generalising public education, by } \\
\text { providing free and compulsory primary education, free and accessible secondary education, and higher education accessible to everyone } \\
\text { according to his or her abilities, and by providing financial support }\end{array}$ \\
\hline
\end{tabular}



inclusive education; gives recommendations for the integration of children with autism in mainstream schools, namely integration has to be tailored to the individual, several conditions-teachers skilled in education children with autism, development of supplementary, individual plans, tools and methods - have to be met in-school, school class should be prepared to facilitate positive attitudes, environment and
continuous support in class, and teachers should cooperate with the familics and expert groups; integrated children should be happy

2012 Act on National Public Education Determines the primary aim of cducation prevent social exclusion; children with SEN have the right to receive education appropriate to their condition in a special or a gencral intcgrative school; cnrolment of a child with SEN cannot be rejected by the local school; for the and specific tools and resources conresponding to the individual condition of f the child provided; teachers are assis ted, consulted and trained by experts and consultants; teacher duties include assuring the development of the child's personality according to their individual abilities, promoting moral development, regularly inform the parents of the child's performance, and respect the rights of the child, participating in further education training at least once every seven years in which they can choose the curriculum and education methods based on the pedagogical programme, and accessing information and further training and to increase their professional knowledge which is necessary for
their work; provides the overall frame of habilititition/rchabilitation lessons of children with SFN, recommending 10.15 hours per weck for

2013 Regulation on the functioning of pedagogical service The pedagogical services operale expert commitlees that prepare opinions on appropriale schools, development tasks on the basis of complex institutions
$2015 \quad$ National Disability Programme 2015-2025 psychological, pedagogical-special-pedagogical and medical examination for children with SEN inclusive education system; sugoested anetwork of travellino pedaoogues with training in special needs education; due to the array of SEN teacher training and education methods have to be evolved and adapted citizens and cqual ity of all peoplc; all citizens have the right to cducation; cducation should be according to individual abilitics and needs

1960 Act on the System of Education and Trainin Emphasised the importance of education and the right of every citizen to free and equal education; acknowledged the importance and 1968 Ústavný z 27. októbra 1968 o československej federácii responsibilitites of teachers in education
Federali isation of the Crechoslovakia remained; creation of Czech Social ist Republic ( $\check{C}$ 'SR) and the Slovak Socialist Republic (SSR) in Czechoslovakia; Czechoslovakia relied on consensus of these bodies; responsibilities were divided between exclusively federal

1977 Decrec on A Unificd System of Continuing Fducation of

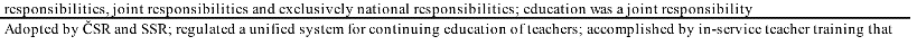
\begin{tabular}{ll} 
Teachers and Ohter Pedagogical and Educational Stall \\
\hline 1980 & Decree on Education Counselling
\end{tabular} also included ideological-political education next to the regular continuous trainin

1984 Fducation Acl counselling for the cducational staff

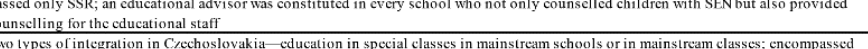

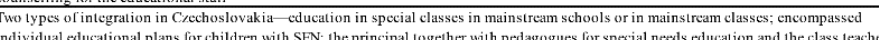
had to create a learming environment in which the student could thrive-including special tools and resources and an individual curriculum which met the SLN
Both states implemented the Education Act similarly; established inclusion of children with SEN; district national committee decided on

1986 Decree of the Ministry of Education of the Czech Socialis Republic on Schools for Young People Requiring Specia \begin{tabular}{ll} 
Carc \\
\hline 1987 & $\begin{array}{l}\text { Decrec of the Ministry of Education of the Slovakian } \\
\text { Socialist Republic on Schools for Young People Requir }\end{array}$
\end{tabular} inclusion and did not require consent of parents/guardians; out-of-class education was focused on to support children with SEN in the bo

1991 Charter of lundamental Rights and l'reedoms

Guaranteed the fundamental rights and freedom of all; established the right to free education for all; all citizens had the right to be educated according to their abilities; citizens had the right to assistance for successful education

1991 Decree on Special Schools

Crech Republic adopted the Charter cntircly in its Constitution; Slovakia integrated clements in its Constitution

1992 Act on the Dissolution of the Czech and Slovak lederative Only adopted in SSR; established different lypes of special schools including a special primary school for children with autism; delined Dots but only with the consent of the parents or legal representatives
SSR and ČSR officially separated on $31-12-1992$, establishing the Czech and Slovak Republic

\begin{tabular}{lll} 
& Republic \\
\hline Crech Republic & 1991 & (iovernment Roard for Pcople with Disabilitics \\
\cline { 2 - 3 } 1993 & Convention on the Rights of the Child
\end{tabular}
1993 Convention on the Rights of the Child Functioncd as an advisory and coordinating body Implementation of the intermational document

Education is based on the principle of free and equal access to education for all without discrimination; goal of education was success ful personal development of children, acquire knowledge of Luropean cultural values and traditions, and understanding principles and rules that arose from the Luropean integration; individual needs and abilities should be considered and respected; development refers to knoweded ge, social competencies, respecting ethical values, democracy, and fundamental human rights; implemented a broader definition of SEN that included children with disabilitics as well as those who were disadvantaged in health or social position; children with SEN were cntitled to
cducation that fit thcir abilititics and necds; schools should create the neccssary conditions for successful cducation; special resources and cducation that fit thcir abilitics and needs; schools should create the necess
tools were free; children with aut ism could be educated in special schools

2005 Decrec on the Provision of Advisory Services in Schools An advisory service was cstablished per school that were responsible for creating suitable conditions for the physical, psychological and and School Counselling Facilitics 2009 Convention on the Rights of Persons with Disabilities 2009 Act on Eyual Treatment and Icgal Protection Against Discrimination
$2010 \quad$ National Plan for the Creation of Liqual Opportunities for

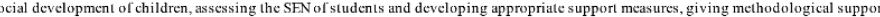
to teachers who were involved in the education of children wilh SEN, and promoting the social inclusion of all children Incorporated relevant EU regulatlions containing equal Irealment and non-discrimination matlers, including access to education Aimed to implement the CRPD and switch from an integrative to an inclusive education system; several means which should be implemented by 2013 , which included increasing additional teaching staff and teaching assistants in classes with children with SLN, creating a genera catalogue of available special needs education resources, preparing an intormation campaign to emphasise the obligation of schoo
provide cducation for all, and improving the organisational process on special cducation counsell ing and diagnostics

$2014 \quad$ Amendments to the Decree on the Provision of $\Lambda$ dvisoly Services in Schools and School Counselling Facilitios Introduced inclusion in education; allowed children with SEN to attend special schools, a special class in mainstream schools or 2 mainstrcam class; school counselling facilitics werc responsible to regularly cvaluate the inclusion of the child and adapt the education National Plan for the Promotion of Equal Opportunities for
Persons with Disabilitics 2015 2020 The plan has three main objectives to implement the education objectives in the CRPD, namely continuing in the system of inclusion, choosing education according to the best interest of the child, and providing support to persons with disabilititis in education at all levels, including lifelong learning; one suggested means to accomplish inclusive education is to establish and evaluale pilot schools; teachers shat partipt Fisabilitites to abolish segregation of those children in special schools

\begin{tabular}{ll}
\hline 2016 & $\begin{array}{l}\text { Decrec on the Fducation of Pupils with Special Fducational } \\
\text { Necds and Ciflicd Pupils }\end{array}$ \\
\hline 2019 & Education Act
\end{tabular} including special tools, individual education plans, and teaching assistants
Broadens the definition of SEN - a person who needs extra support measures in order to exercise his or her right of equal education; specifies rights and duties of teachers, such as using their own education methods as long it is in accordance with the stated principles and objectives of education; teachers are obligated to protect and respect the rights of the child and create a positive school and learning environment

Slovakia $\quad 1993$ Convention on the Rights of the Child 2003 Amendment of the Decree on Special Schools Implementation of the international document

Introduced inclusive language

SEN is delined as the need to modify conditions, content, forms, methods, and approaches in education and training for a child resulling from health disadvantage or development in a socialy disadvantaged environment for achieving an appropriate evevel or edacation and integration

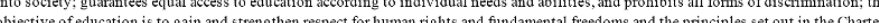
for the Protection of Human Rights and Fundamental Freedoms, reassuring the importance of the 1991 Czechoslovakian Charter, education of children with SFN can cither take placc in a special school, a spccial class in a mainstrcam school, or a mainstream school; schools havc to follow a specifie education programme depending on the SFN of the child; developed 12 different education programmes according to the disability of the child, one of which perlains exclusively to autism-though the progranmes are not specilied; mainstream schools with children with SEN need to employ special needs education teachers and school psychologists; reiterates the rights of children, such as equal and free access to education and receive education according to individual abilities and conditions, which includes access to facilities, tool
and resources; children who have communication difficulties can receive education through alternative measures of communication Stresses the importance of education in Slovakia

2009 Act on Lifelong Learning

2009 Act on Liducational Staff and Professional Limployees Teachers have the right to work in a safe environment and be protected from unprofessional interference in their educational activities and to receive continuing education and training for professional development; teaching staff can participate in the management of the school through elected representatives they can select and apply the cducation methods which are most suitable for creating optimal learning and legal guardian about the learning progress: leachers need to honour individual educational needs of their children through guidance an counselling of the child and objective evaluation of his or her work; educational stalf has to parlicipate in life-long learning training to maintain and evolve their competences; distinguishes three types of special needs education professionals, namely special pedagogues that ate responsible for the diagnosis of SLN and for an intervention plan-he or she counsels and consulates the education staff and the legal representative of the child, special school teachers that carry out teaching and education activities, and field-special pedagogues who provide preventive, educational and methodological activities and provide counselling for children with SEN

2010 Convention on the Rights of Persons with Disabilitice Implementation of the international documen!

2014 Strategy of the Slovak Republic for Youth $2014-2020 \quad$ The goal for education is to support and enhance inclusion; stipulates that inclusion and education legislation should be analysed and have its effectiveness examined; legislation to vali iate pedagogic quality within education should be established; a national platform to improv

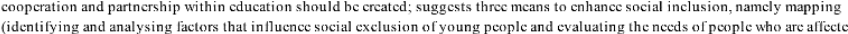
social exclusion), prevention (developing measures to prevent social exclusion), and new services (providing new services to abolish exclusion) 


\section{Supplementary File 2}

\section{Austria}

Federal state Kärnten [Austria]. (2019). Landesetappenplan 2014 - 2020.

Federal state Steiermark [Austria]. (2012). Umsetzung der UN-Behindertenrechtskonvention. Aktionsplan des Landes Steiermark. Phase 1: 2012-2014.

Federal state Steiermark [Austria]. (2015). Umsetzung der UN-Behindertenrechtskonvention. Aktionsplan des Landes Steiermark. Phase 2: 2015-2017.

Federal state Steiermark [Austria]. (2018). Umsetzung der UN-Behindertenrechtskonvention. Aktionsplan des Landes Steiermark. Phase 3: 2018-2012.

Federal state Tirol [Austria]. (2015). Inklusive Bildung in Tirol. Eine Stellungnahme des Tiroler Monitoringausschusses zur Überwachung der UN-Konvention über die Rechte von Menschen mit Behinderungen.

Federal state Tirol [Austria]. (2016). Pädagogische Beratungszentren: PBZ. Modell Tirol.

Federal state Tirol [Austria]. (2018). Tiroler Teilhabegesetz (32/2018).

Republic of Austria. (1945). Verfassungsgesetz vom 1. Mai 1945 über das neuerliche Wirksamwerden des Bundes-Verfassungsgesetzes in der Fassung von 1929.

Republic of Austria. (1955). Staatsvertrag, betreffen die Wiederherstellung eines unabhängigen und demokratischen Österreich.

Republic of Austria. (1964). 59. Bundesverfassungsgesetz.

Republic of Austria. (1975). 5. Schulorganisationsgesetz-Novelle.

Republic of Austria. (1993a). 15. Schulorganisationsgesetz-Novelle.

Republic of Austria. (1993b). Änderung des Schulpflichtgesetzes 1985.

Republic of Austria. (1996). Änderung des Schulorganisationsgesetzes.

Republic of Austria. (2005). Bundes-Behindertengleichstellungsgesetz.

Republic of Austria. (2015). Verbindliche Richtlinie zur Entwicklung von Inklusiven Modellregionen (17/2015).

Republic of Austria. (2016). 219. Änderung der Verordnung über die Lehrpläne der allgemein bildenden höheren Schulen.

Republic of Austria. (2017). Bildungsreformgesetz 2017 (138/2017).

Republic of Austria. (2019). Bundes-Verfassungsgesetz (B-VG).

\section{Hungary}

Republic of Hungary. (1988). 1998. évi XXVI. törvény a fogyatékos személyek jogairól és esélyegyenlöségük biztositásáról. 
Republic of Hungary. (1993). 1993. évi LXXIX. törvény a közoktatásról.

Republic of Hungary. (2005). 2/2005. (III. 1.) OM rendelet a Sajátos nevelési igényü gyermekek óvodai nevelésének irányelve és a Sajátos nevelési igényü tanulók iskolai oktatásának irányelve kiadásáról.

Republic of Hungary. (2011a). 2011. évi CXC. törvény a nemzeti köznevelésröl.

Republic of Hungary. (2011b). Magyarország Alaptörvénye: 2011. április 25.

Republic of Hungary. (2012a). 20/2012. (VIII. 31.) EMMI Regulation on the operation of educational institutions and the use of names of public educational institutions.

Republic of Hungary. (2012b). 32/2012. (X. 8.) EMMI rendelet a Sajátos nevelési igényü gyermekek óvodai nevelésének irányelve és a Sajátos nevelési igényü tanulók iskolai oktatásának irányelve kiadásáról.

Republic of Hungary. (2012c). Verfassung der Ungarischen Republik (1949/1989).

Republic of Hungary. (2013a). 1330/2013. (VI. 13.) Government Resolution on the National Disability Council.

Republic of Hungary. (2013b). 15/2013. (II. 26.) EMMI Regulation on the functioning of pedagogical service institutions.

Republic of Hungary. (2015). 15/2015. (IV. 7.) OGY határozat az Országos Fogyatékosságügyi Programról (2015-2025).

\section{Czech Republic}

Czech Republic. (1948). Ústavní zákon ze dne 9. května 1948 Ústava Československé republiky.

Czech Republic. (1991a). Government Board for People with Disabilities.

Czech Republic. (1991b). Listina Základních Práv A Svobod.

Czech Republic. (1992). Ústava České republiky ze dne 16. prosince 1992.

Czech Republic. (2004). 561/2004: Zákon o předškolním, základním středním, vyšším odborném a jiném vzdělávání (školský zákon).

Czech Republic. (2005). 72/2005 Vyhláška o poskytování poradenských služeb ve školách a školských poradenských zařizeních.

Czech Republic. (2009). Zákon o rovném zacházení a o právních prostředcích ochrany před diskriminací a o změně některých zákonů (antidiskriminační zákon) (198/2009).

Czech Republic. (2014). 103/2014 Vyhláška, kterou se mění vyhláška č. 72/2005 Sb., o poskytování poradenských služeb ve školách a školských poradenských zařízeních.

Czech Republic. (2016). 27/2016 Vyhláška o vzdělávání žáků se speciálními vzdělávacími 
potřebami a žáki̊ nadaných.

Czech Republic. (2019). 46/2019 Zákon, kterým se mění zákon č. 561/2004 Sb., o předškolním, základním, středním, vyšším odborném a jiném vzdělávání (školský zákon).

\section{Slovakia}

Republic of Slovakia. (1960). 186/1960 Zákon o sústave výchovy a vzdelávania.

Republic of Slovakia. (1968). Ústavný z 27. októbra 1968 o československej federácii.

Republic of Slovakia. (1977a). 79/1977 Zb. Vyhláška ministerstva školství České socialistické republiky o jednotném systému dalšiho vzdělávání učitelů škol poskytujících základní, střední a vyšší vzdèlání a ostatních pedagogických a výchovných pracovníků.

Republic of Slovakia. (1977b). 80/1977 Zb. - Vyhláška Ministerstva školstva Slovenskej socialistickej republiky o jednotnom systéme d'alšieho vzdelávania učitel'ov škôl poskytujúcich základné, stredné a vyššie vzdelanie a ostatných pedagogických a výchovných pracovnikov.

Republic of Slovakia. (1980). 99/1980 Zb. - Vyhláška Ministerstva školstva Slovenskej socialistickej republiky o výchovnom poradenstve.

Republic of Slovakia. (1984). 29/1984 Zb. - Zákon o sústave základných a stredných škôl (školský zákon).

Republic of Slovakia. (1986). 49/1986 Zb. - Vyhláška ministerstva školství České socialistické republiky o školách pro mládež vyžadujících zvláštní péči.

Republic of Slovakia. (1987). 2/1987 Zb. - Vyhláška Ministerstva školstva Slovenskej socialistickej republiky o školách pre mládež vyžadujúcu osobitnú starostlivost'.

Republic of Slovakia. (1991). 212/1991 Zb. - Vyhláška Ministerstva školstva, mládeže a športu Slovenskej republiky o špeciálnych školách.

Republic of Slovakia. (1992a). Ústava Slovenskej republiky z 1. septembra 1992 (460/1992).

Republic of Slovakia. (1992b). Ústavný Zákon z 25. novembra 1992 o zániku Českej a Slovenskej Federatívnej Republiky.

Republic of Slovakia. (2003). 364/2003 Z.z. - Vyhláška Ministerstva školstva Slovenskej republiky ktorou sa mení a doplña vyhláška Ministerstva školstva, mládeže a športu Slovenskej republiky č. 212/1991 Zb.

Republic of Slovakia. (2008). 245/2008 Z.z. - Zákon o výchove a vzdelávaní (školský zákon) a o zmene a doplnení niektorých zákonov.

Republic of Slovakia. (2009a). 317/2009 Z.z. - Zákon o pedagogických zamestnancoch a odborných zamestnancoch a o zmene a doplnení niektorých zákonov. 
Republic of Slovakia. (2009b). 568/2009 Z.z. - Zákon o celoživotnom vzdelávaní a o zmene a doplnení niektorých zákonov.

Republic of Slovakia. (2014). Strategy Of The Slovak Republic For Youth For The Years 2014 - 2020. 


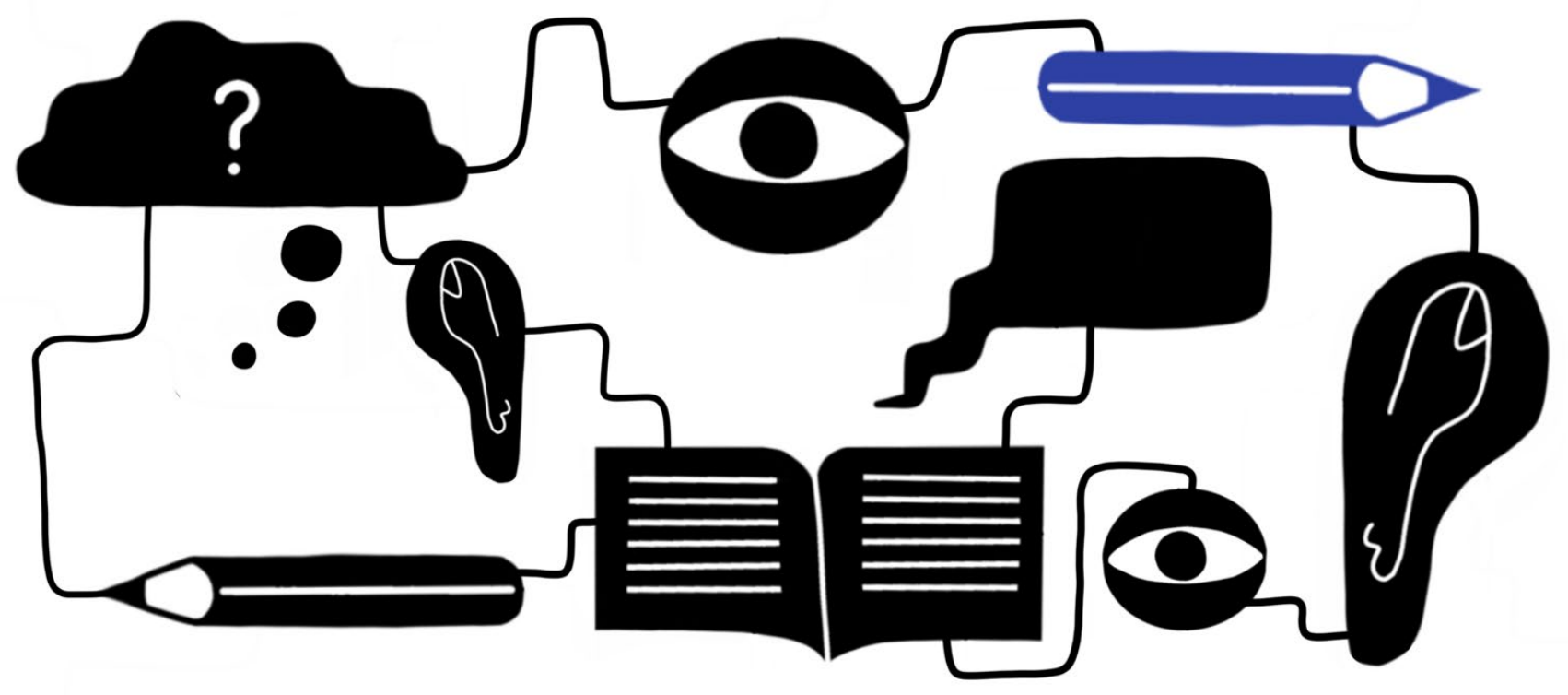

\section{Chapter Four}

Education Policy in Small EU Member States

\section{Published as:}

van Kessel, R., Hrzic, R., Czabanowska, K., Baranger, A., Azzopardi-Muscat, N., Charambalous-Darden, N., Brayne, C., Baron-Cohen, S., \& Roman-Urrestarazu, A. Autism and Education-International Policy in Small EU States: Policy Mapping in Malta, Cyprus, Luxembourg, and Slovenia. [Accepted July 2020 in European Journal of Public Health; IF(2019): 2,391] 


\begin{abstract}
Background: Special education provides an array of support that can advantageously meet special education needs (SEN) of children with autism. This report maps autism and SEN policies, and tension of international legislation in Malta, Cyprus, Luxembourg, and Slovenia.

Methods: A policy path analysis was performed using a scoping review as fundamental methodological framework.

Results: Education for children with SEN developed from limited education towards segregation, and further to integration, and inclusion in mainstream education. International policy has greatly influenced the education systems under study. The rights to education and to have SEN addressed have been adopted in all countries. Inclusion is seen to be gradually incorporated by Malta, Cyprus, and Luxembourg - closely following values of international documents through concise SEN policies. Slovenia's education system remains segregated, indicating potential tension.

Conclusion: It appears that mainstream schools offer SEN services until no longer feasible for the child in the majority of investigated countries. Inclusion has become a guiding principle for most education systems under study. Finally, small states either commit to the implementation of inclusion or delay it and attempt to improve the education system for children with SEN in different ways.
\end{abstract}

\title{
Keywords
}

Autism, education, special education needs, inclusion, small states 


\section{Introduction}

Several studies have investigated the tension between big and small European Union (EU) Member States in their approach towards European involvement in aspects of policy traditionally left to Member States including health and education. ${ }^{1-4}$ Small states, in this context, are defined as states that not only have a small population size, but also are not in a position to influence the international policy environment on their own and are, by extension, largely dependent on the decisions of larger states and overarching political structures.

With the respective adoption of the Universal Declaration of Human Rights (UDHR) in 1948 and the Convention of the Rights of Persons with Disabilities (CRPD) in 2006, ${ }^{5,6}$ the right to education for children with special education needs (SEN) internationally has been wellestablished. Its values of the UDHR have significantly influenced the course of disability and education policy in the previously investigated countries. The CRPD covers people with disabilities and it highlights that children with disabilities need to be able to fully enjoy all human rights and fundamental freedoms equally to other children. As a result, it cements any future development of children and people with disabilities and their right to education. However, implementing this right with respect to access to education for children with autism in the EU has been challenging. ${ }^{7}$ With a male-to-female ratio between $3: 1$ and 4:1, autism affects roughly $1 \%$ of the population. ${ }^{8,9}$ Autistic people may be more susceptible to severe health and other functional difficulties that may result in financial problems for families and caregivers and the condition can still carry considerable stigma. ${ }^{10-13}$ To address these circumstances and increase the inclusion and quality of life of autistic people and the autism community across Europe, the application of fundamental rights of education is paramount. ${ }^{14,15}$

It is pivotal for EU Member States to provide adequate SEN services starting from early childhood and continuing throughout school years, while simultaneously supporting autistic people in life-long education. ${ }^{8,16}$ The evidence base of SEN support has been reported previously: ${ }^{7}$ Support in cognition and learning; social, emotional and mental health; and communication and interaction could lead to significant benefits for the development of children with SEN, while also acknowledging that the SEN for children with autism may differ significantly per person. It also emphasized the importance of children having their SEN met in education settings. A recent example of a novel approach to SEN that has been adopted by schools is inclusive education, ${ }^{15}$ in which the required SEN services are provided 
in a mainstream education setting, enabling children with SEN to engage in education along with typical peers. Providing these services adequately can result in major benefits for a child's cognitive and social development.

This paper focuses on mapping SEN and autism policy in Malta, Cyprus, Luxembourg, and Slovenia. These countries make up four out of the five smallest EU Member States and are therefore deemed suitable to fill the definition of small state. ${ }^{17}$ Since small states often experience tension when dealing with the implementation of international policies, the second aim of this paper is to investigate the extent of this tension in the area of autism and special education policy. It should be noted that, even though Estonia fits the definition of a small state, it was not included as it joined the UN significantly later (1991) compared to the other countries under study (Malta 1964, Cyprus 1960, Luxembourg 1945, Slovenia 1945 [as part of former Yugoslavia]) and had been under communist influence prior to its independence. ${ }^{18}$ Determining the influence of the communist era on the national policy environment on top of investigating possible tensions would be beyond the scope of this study.

\section{Methods}

The policy mapping framework in this paper is based on previously validated work. ${ }^{19,20}$ Data were gathered through a scoping review and analysed through a policy path dependence analysis. ${ }^{22-24}$ Due to the absence of a comprehensive EU data source on autism and SEN policy, a modular approach was adopted to analyse the education policy environments under study. The findings were reported using the PRISMA framework. ${ }^{25}$

\section{Eligibility Criteria}

Consistent with previous work, ${ }^{19-21}$ inclusion criteria consisted of (1) a scope relating to the right to education, national education system, disability laws, inclusion, or special education needs; (2) aimed at children under 18 years; (3) drafted by a governmental institution; and (4) published after 1948. Constitutions were always included and no language limitations were set. Non-governmental policies and actions were excluded.

\section{Data Collection and Search Strategy}

Like previous work, ${ }^{19-21}$ the data collection consisted of five steps in which governmental websites formed the primary source for data collection: (1) review and extract policies 
relevant to the education of children with SEN; (2) develop a multi-layered search strategy for scientific databases (Google Scholar/PubMed); (3) merge policy and academic publications conform the eligibility criteria; (4) acquire further information through searching reference lists; and (5) merge all documents into one data repository for the purpose of this scoping review and path dependence analysis.

Table 1 shows the policy repositories that were used per country. The search strategy involved searching full-texts for the respective keywords, instead of just titles and abstracts in order to minimize the risk of overlooking policy as a result of inaccurate or incomplete translations. The used keywords consisted of: autism, disability, special education needs, education, special needs, special education, and inclusive education. These were translated into French (Luxembourg), Greek (Cyprus), and Slovenian respectively and used individually, as combining the keywords in the policy repositories yielded little relevant results. Subsequently, the exact build-up of the search query used for scientific databases is shown in Table 2. The data collection took place between February $2^{\text {nd }}$ and April $9^{\text {th }} 2019$. Sources from a later date were added as a result of consulting country experts.

Table 1 . The policy databases used per country.

\begin{tabular}{ll}
\hline Country & Link \\
\hline All & http://eur-lex.europa.eu/n-lex/ \\
\hline Malta & http://justiceservices.gov.mt \\
& https://education.gov.mt/en/education/student- \\
& services/Pages/default.aspx \\
& http://www.legislation.mt/ \\
\hline Cyprus & http://www.cylaw.org \\
\hline Luxembourg & $\mathrm{http}: / /$ legilux.public.lu/ \\
\hline Slovenia & $\mathrm{http}: / /$ www.pisrs.si/Pis.web/\# \\
\hline
\end{tabular}


Table 2. The build-up of the final search query for academic databases.

\begin{tabular}{|c|c|}
\hline & Search Query \\
\hline Term 1 & $\begin{array}{l}\text { ((((((((()autism \& law) OR autism \& policy) OR autism \& SEN) OR autism \& } \\
\text { education) OR autism \& disability) OR SEN \& policy) OR SEN \& law) OR } \\
\text { disability \& law) OR disability \& policy }))\end{array}$ \\
\hline Term 2 & (Malta OR Cyprus OR Luxembourg OR Slovenia) \\
\hline Final Query & $\begin{array}{l}\text { (((((((((autism \& law) OR autism \& policy) OR autism \& SEN) OR autism \& } \\
\text { education) OR autism \& disability) OR SEN \& policy) OR SEN \& law) OR } \\
\text { disability \& law) OR disability \& policy)) AND ((Malta OR Cyprus OR } \\
\text { Luxembourg OR Slovenia)) }\end{array}$ \\
\hline
\end{tabular}

\section{Data Analysis}

Gathered data was compared to data on UN and EU policy in previous work. ${ }^{19-21}$ As such, the extent to which the values of international policies are integrated in the national policies could be established. To gauge possible tension in the small Member States, we tracked the implementation of various values that were set out in international policy: (1) the universal right to education laid down in the UDHR; (2) the right for children to receive appropriate treatment consistent with their condition by the Declaration on the Rights of the Child; (3) the right for children with developmental, intellectual, and learning conditions to receive appropriate education to maximize their potential by the Declaration on the Rights of Disabled Persons; and (4) the development of an inclusive education environment as set out by the Salamanca Statement and the CRPD. Lack of implementation of any of these points is considered tension.

\section{Results}

We identified 15129 sources (94 for Malta, 5583 for Cyprus, 2622 for Luxembourg, 6830 for Slovenia) through database searching and 7 through other sources. CyLaw returned individual chapters, rather than complete documents. As such, the entire policy document was included if two separate chapters of the same document were identified by the search query. Fifty-one documents ( 8 for Malta, 17 for Cyprus, 9 for Luxembourg, and 17 for Slovenia) were ultimately included in this review. A PRISMA flowchart illustrates the entire process in Figure 1. A synopsis of the policy contents is included in Supplementary file 1. Supplementary file 2 shows the policy and academic documents that were used per country. 

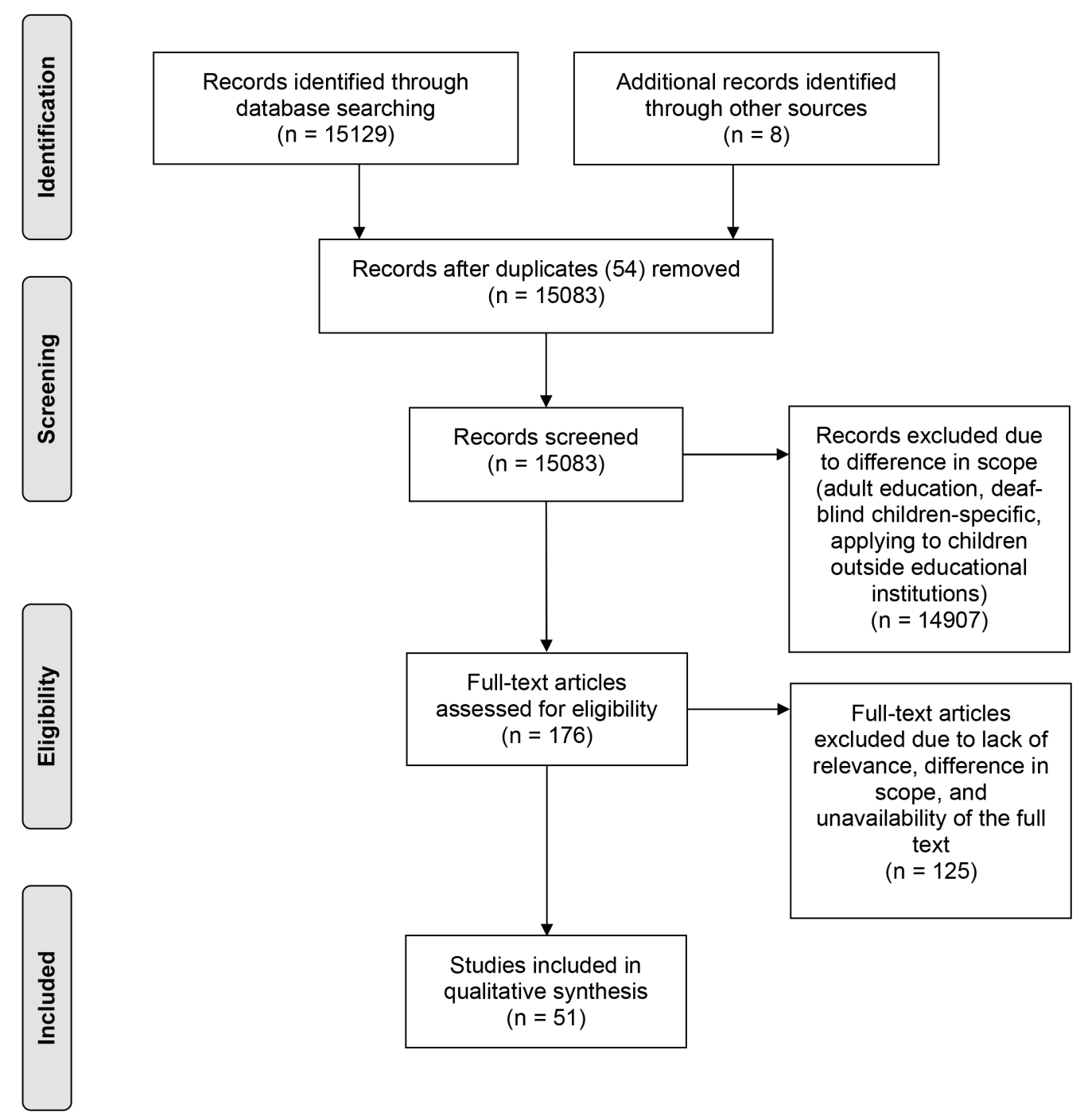

Figure 1. A visualisation of the process that was used to select relevant articles from the search strategy.

\section{Malta}

The development of Maltese SEN policy is divided into two categories: the development of the education system and the empowerment of people with disabilities. Firstly, the development of the education system is covered by the Education Act (1988), creating an environment where all children were guaranteed primary education. It provided a definition of SEN — a child that has particular difficulties of physical, intellectual, sensory, or psychological essence - and established Resource Centres, aimed to educate children with SEN who were unable to follow mainstream education, effectively ensuring a place for every child in the education system. Secondly, the empowerment of people with disabilities is achieved through the Equal Opportunities (Persons with Disabilities)-, Mental Health-, and Persons within the Autism Spectrum (Empowerment) Act of 2000. While the former two 
heavily focus on establishing rights for people with disabilities, the latter expanded on this by formulating clear guidelines on how to improve the environment for people with autism in terms of (1) improving the education of pupils with autism; (2) informing people close to the person with autism; and (3) raising awareness. Malta adopted a new Education Act in 2019, in which the right to education was re-emphasised. It also expanded the environment of inclusion by requiring teachers to keep developing themselves professionally and create collaborations between teachers, children, and parental committees as to ensure high-quality education.

In Malta, autism falls under inclusive education policy and the Autism Spectrum Support Service is specifically geared towards children with autism. ${ }^{26}$ It recognizes that each student is an individual, and seeks to maximise the student's potential. ${ }^{27}$ It aims to empower educators and parents to meet the individual education needs of the child with autism, facilitating learning, supporting behavioural and social development and maximising on students' abilities in mainstream and resource environment. Additionally, a national early screening program for autism has been established. ${ }^{28}$ It is a simple means to help identify possible developmental delays, learning difficulties, and/or education needs related to autism so children can be supported before starting kindergarten. Furthermore, it involves a process that starts at the age of eighteen months through M-CHAT - a short questionnaire which is carried out with the parents or guardians and helps provide an indication of any risks relating to autism. The development of an inclusive education system in Malta also does not signal tension and is in line with internationally available guidance.

\section{Cyprus}

The first special school was established in 1929 and by 1979 all special schools were established. ${ }^{29}$ A draft legislation was initiated in 1979 to monitor issues regarding special schools. ${ }^{30}$ This draft resulted in a new law that legalized the operations of special schools: The Special Education Act.

The Education and Training of Children with Special Needs Act of 1999 was essential for the Cypriot education system, ${ }^{31}$ as children with SEN were no longer only educated in special schools, but also placed in more specialised institutions. The Education and Training of Children with Special Needs Act passed in 1999 came in effect in 2001, which resulted in a split system of education. Only the children with mild-to-moderate SEN were placed into 
mainstream school settings, while children with more severe SEN were separated and placed in special schools or institutions. These remained unprepared to accept children with more severe SEN due to lacking infrastructure to ensure quality education. ${ }^{29,32,33}$

Jones and Symeonidou elaborate on the Code of Practice for Referring Children with Special Needs to the Special Education and Training District Committees that aims to motivate schools and teachers to work with children that are suspected to have SEN before referring them for assessment, and work on early detection mechanisms for SEN. ${ }^{31}$ Inclusion was introduced in the 2014 amendments to the Education and Training of Children with Special Needs Act. No distinction between various disabilities is made though. Therefore, no specialized provisions for autism specifically are established. Circulars in 2016, 2018, and 2019 targeted to improve education and train teachers in working with children with autism - further solidifying their right to receive appropriate education. Ultimately, education in Cyprus has evolved from a segregated system towards a system of inclusion in line with international guidance, indicating no tension.

\section{Luxembourg}

Policies until 1994 developed the education system in Luxembourg so that every child can follow a form of education. Compulsory education required all children to receive nine consecutive years of education - in special classes if necessary. The introduction of differentiated education allowed children that could not function in special classes to receive education according to their capabilities. In this education setting, teachers were assisted by an array of supporting staff.

Policies after 1994 focused on the development of more inclusive practices. Children with SEN had the option to attend either mainstream education, in which case individualized care plans were implemented to help adjust, special education, or differentiated education. Furthermore, specialized centres were implemented to aid with the uptake of children with SEN in the education system by aiding the personal development of the child and the schools.

Ultimately, the education system in Luxembourg is regulated in such a way that there is room for every child in the system. They initially implemented a segregated education environment through differentiated education, although this has evolved towards a more 
integrated/inclusive approach that is in line with international guidance, while retaining the option of segregated schools in case a child cannot participate in mainstream schools.

\section{Slovenia}

The initial focus of the Slovenian education system, which encompasses the policies up to 2005, was the development of a non-discriminatory environment where all children have a place. Children with SEN followed a modified version of the mainstream curriculum that was adapted to their needs. These adaptations could be in the form of additional professional assistance, as well as adaptation of class sizes - ranging between four and twelve pupils per class depending on the severity of their conditions. Modified education programs were also made available for children with SEN to use.

Policies from 2010 onwards intend to develop SEN education to be on par with education for typical children - to the point a tailored primary school program of equivalent education standards is created for children with autism. There is a small notion of inclusion of children with SEN in education systems and that children with SEN should be guided to the most suitable education program. Overall, policies work towards the improvement of the existing segregated system, though never progressing towards and integrative or inclusive environment.

In short, the education system in Slovenia has seen a development of their education system that is consistent with the values set out by most respective international documents - the only point of tension being the move towards inclusion. A unique element in the Slovenian system is the elaborate regulation on class sizes depending on the condition of the children. Numerous policies were implemented specifically in an attempt to equalize and/or unify the values of educational achievements in mainstream and special education.

\section{Discussion}

This study aimed to map autism and SEN policies in Malta, Cyprus, Luxembourg, and Slovenia and to investigate how international SEN and human right policy was addressed at the national policy level in these small states. All relevant SEN policies that affect the education of children with autism and their universal right to education were mapped. 
The UDHR formed a critical juncture in international, EU, and national policy. ${ }^{19-21}$ Integration and inclusion became guiding principles in most countries-except Slovenia. Legislation was found to address discrimination of people on basis of disability. International documents greatly influenced the development of national education systems - most notably the right to education for all children, the right to have SEN adequately addressed, and the ideology of inclusive education have been adopted by most countries under study.

An inference was made previously that health reforms in small states are predominantly lead by shifting ideologies over supranational influence. ${ }^{1,2}$ However, education policy development closely follow the values set out in guiding international documents and their approaches also resemble the actions of larger EU Member States-particularly regarding inclusive education and allocating responsibilities to address SEN to schools and teachers. ${ }^{21}$ Finally, almost no policy across the countries under study establishes or recommends specific tools or tool requirements, except for Malta. ${ }^{28}$

Some cross-country differences were found. Malta was the only country that had adopted policy, aiming to include children with autism specifically in the education system. While the others adopted their own policy in enabling children with SEN to access education, the scope of the Maltese legislation expanded beyond that-intending to fully integrate autistic people in society on par with typical people, focusing health, well-being, participation, and striving for autonomy for their autism community. Moreover, Malta implemented specific services aiding educators and parents in addressing the needs of a child with autism and an autismspecific screening program that starts at the age of 18 months. Since the earliest symptoms of autism generally appear between the age of 6 and 12 months,${ }^{8}$ this screening program can benefit early identification and early intervention for children with autism. Slovenia prescribed class sizes of primary, secondary, and special education programs based on SEN categories that would be present in-class, along with possibilities of home schooling. Organizations for people with disabilities were introduced, promoting their human rights, non-discrimination, and equal opportunities. Interestingly, Slovenia adopted a higher number of education policies that pertain to SEN. A possible explanation for this is that Slovenian policies tend to introduce small/incremental changes, whereas the other countries' policies introduce larger-scale changes. While no approach is inherently superior to the other, the Slovenian approach may run the risk of becoming too specific, which could potentially lead to the fragmentation of education for children with different SEN. Finally, no policy 
initiatives were found in Cyprus to increase awareness of SEN, autism, or mental health in general. Regardless, it is unknown to what extent mental health awareness is already being raised in the community by NGOs for example.

Compared to larger countries, the findings of this study indicate that, during the development of the respective education systems, small states tend to establish separate institutions that tend to the various needs of children with SEN, including health and education-going beyond the scope of special schools that were commonly established in larger countries. ${ }^{19-21}$ This tendency was also found in the German-speaking community in Belgium, which holds the characteristics of a small state. ${ }^{20}$ Additionally, small states either commit to the implementation of inclusive education as soon as possible (Malta, Cyprus, Luxembourg) or delay it and attempt to improve the education environment for children with SEN in other ways (Slovenia), whereas larger countries tend to adopt a gradual implementation in which the system in-place slowly shifts towards inclusion. ${ }^{19,20}$

This scoping review has some limitations that should be accounted for. Results of this study cannot be generalized beyond the investigated countries; outcomes of this study remain strictly theoretical as the practical situation was not investigated (for instance the findings of Cyprus insinuate that children have not been properly assessed on whether they have SEN when they come to school, which would be crucial to assess in-practice); the possibility of errors in translation or misinterpretation cannot be dismissed - though Maltese, Cypriot, Luxembourgian, and Slovenian experts were involved to assist interpreting the legislation for the respective countries; only governmental documents were included in this research, disregarding actions belonging to NGOs; the terms 'autistic' and 'disabled' were not included in the search terms - though this is ameliorated by involving country experts and the search strategy using full-texts rather than titles only; and the scope of the search strategy of this study was strictly limited to children-meaning individuals under the age of 18. Adult education was not covered, even though similar challenges with SEN may be present there.

Ultimately, this study provided insight in the SEN policy environment of Malta, Cyprus, Luxembourg, and Slovenia. Path dependency analysis indicates the integration of most values of the UDHR, CRPD and other international documents in their education systems through national legislation. Mainstream schools offer SEN services and support until children cannot participate in mainstream education. At that point, specialized institutions are in charge of the 
education of the children. Inclusive education has become a guiding factor in the education systems of most countries under study. Finally, all countries under study account for children with autism in their respective education policy_-with Slovenia retaining segregation, while Malta, Cyprus, and Luxembourg work towards inclusion.

\section{Key Points}

- Data suggests that inclusion is a guiding factor for education systems and being implemented is the majority of small EU states;

- Access to education for children with special education needs is facilitated in all countries under study;

- Little tension is found in the translation of international education values to national policies, indicating their priority to update education according to the latest evidence.

\section{References}

1 Azzopardi-Muscat N, Funk T, Buttigieg SC, Grech KE, Brand H. Policy challenges and reforms in small EU member state health systems: a narrative literature review. Eur J Public Health 2016;26:916-22.

2 Azzopardi-Muscat N, Sorensen K, Aluttis C, Pace R, Brand H. Europeanisation of health systems: a qualitative study of domestic actors in a small state. BMC Public Health 2016;16:334.

3 Thorhallsson B, Wivel A. Small States in the European Union: What Do We Know and What Would We Like to Know? Cambridge Rev Int Aff 2006;19:651-68.

4 Haugevik K, Rieker P. Autonomy or integration? Small-state responses to a changing European security landscape. Glob Aff 2017;3:211-21.

5 United Nations. Universal Declaration of Human Rights. 1948URL http://www.un.org/en/udhrbook/pdf/udhr_booklet_en_web.pdf.

6 United Nations. Convention on the Rights of Persons with Disabilities. 2006URL http://www.ohchr.org/EN/HRBodies/CRPD/Pages/ConventionRightsPersonsWithDisa bilities.aspx\#3.

7 Carroll J, Bradley L, Crawford H, Hannant P, Johnson H, Thompson A. SEN support: A rapid evidence assessment. 2017.

8 Lai M-C, Lombardo M V, Baron-Cohen S. Autism. Lancet 2014;383:896-910.

9 Loomes R, Hull L, Mandy WPL. What Is the Male-to-Female Ratio in Autism 
Spectrum Disorder? A Systematic Review and Meta-Analysis. J Am Acad Child Adolesc Psychiatry 2017;56:466-74.

10 Knapp M, Romeo R, Beecham J. Economic cost of autism in the UK. Autism 2009; 13:317-36.

11 Howlin P, Goode S, Hutton J, Rutter M. Adult outcome for children with autism. $J$ Child Psychol Psychiatry 2004;45:212-29.

12 van Heijst BFC, Geurts HM. Quality of life in autism across the lifespan: A metaanalysis. Autism 2015;19:158-67.

13 World Health Organisation. Autism spectrum disorders. 2017.URL http://www.who.int/mediacentre/factsheets/autism-spectrum-disorders/en/ Accessed 25 April 2018.

14 European Commission. European Disability Strategy 2010-2020: A Renewed Commitment to a Barrier-Free Europe. 2010.

15 Hehir T, Grindal T, Freeman B, Lamoreau R, Borquaye Y, Burke S. A Summary of the Research Evidence on Inclusive Education. São Paulo: Instituto Alana, 2016URL https://www.abtassociates.com/sites/default/files/2019-

03/A_Summary_of_the_evidence_on_inclusive_education.pdf.

16 Baron-Cohen S. Editorial Perspective: Neurodiversity-a revolutionary concept for autism and psychiatry. $J$ Child Psychol Psychiatry 2017;58:744-47.

17 Eurostat. Population change - Demographic balance and crude rates at national level. 2018.URL

http://appsso.eurostat.ec.europa.eu/nui/show.do?dataset=demo_gind\&lang=en Accessed 30 April 2018.

18 United Nations. Growth in United Nations membership, 1945-present. 2020.URL https://www.un.org/en/sections/member-states/growth-united-nations-membership1945-present/index.html Accessed 5 July 2020.

19 Roleska M, Roman-Urrestarazu A, Griffiths S, et al. Autism and the right to education in the EU: Policy mapping and scoping review of the United Kingdom, France, Poland and Spain. PLoS One 2018;13:e202336.

20 van Kessel R, Roman-Urrestarazu A, Ruigrok A, et al. Autism and family involvement in the right to education in the EU: policy mapping in the Netherlands, Belgium and Germany. Mol Autism 2019;10. doi:10.1186/s13229-019-0297-x.

21 van Kessel R, Walsh S, Ruigrok AN V., et al. Autism and the right to education in the EU: policy mapping and scoping review of Nordic countries Denmark, Finland, and 
Sweden. Mol Autism 2019;10. doi:10.1186/s13229-019-0290-4.

22 Arksey H, O’Malley L. Scoping studies: towards a methodological framework. Int J Soc Res Methodol 2005;8:19-32.

23 Levac D, Colquhoun H, O’Brien KK. Scoping studies: advancing the methodology. Implement Sci 2010;5:69.

24 Mahoney J. Path dependence in historical sociology. Theory Soc 2000;29:507-48.

25 Moher D, Liberati A, Tetzlaff J, Altman DG, PRISMA Group. Preferred reporting items for systematic reviews and meta-analyses: the PRISMA statement. BMJ 2009;339:b2535.

26 Spiteri L, Borg G, Callus AM, Cauchi J, Sciberras M. Inclusive and Special Education Review. Floriana, 2005URL https://education.gov.mt/en/resources/Documents/Policy Documents/inclusive and special education review.pdf Accessed 22 August 2019.

27 Government of Malta. Autism Spectrum Support Team. 2016.URL https://education.gov.mt/en/education/studentservices/Pages/Inclusive_Education/Autism-Spectrum-Support-Team.aspx Accessed 22 August 2019.

28 Government of Malta. Lenti fuq 1-Iżvilupp ta` Wliedna. 2016.URL https://education.gov.mt/en/Lenti/Pages/Lenti.aspx Accessed 22 August 2019.

29 Phtiaka H. Educating the Other: A Journey in Cyprus Time and Space. In: Policy, Experience and Change: Cross-Cultural Reflections on Inclusive Education. Dordrecht: Springer Netherlands, 2008; 147-61.

30 Symeonidou S. Parental involvement in education politics: the case of disabled children. Mediterr J Educ Stud 2007;12:45-67.

31 Jones C, Symeonidou S. The Hare and the Tortoise: a comparative review of the drive towards inclusive education policies in England and Cyprus. Int J Incl Educ 2017;21:775-89.

32 Hadjikakou K, Petridou L, Stylianou C. The academic and social inclusion of oral deaf and hard-of-hearing children in Cyprus secondary general education: investigating the perspectives of the stakeholders. Eur J Spec Needs Educ 2008;23:17-29.

33 Liasidou A. Inclusive education policies and the feasibility of educational change: the case of Cyprus. Int Stud Sociol Educ 2007;17:329-47. 


\section{Supplementary File 1}

\section{Supplementary Material}

\begin{tabular}{|c|c|c|c|}
\hline Country & Year & Policy & Description \\
\hline \multirow[t]{3}{*}{ Malta } & 1988 & Education Act & $\begin{array}{l}\text { Compulsory education was introduced for children between five and fifteen years old } \\
\text { The duty of the State to facilitate primary education to all Maltese citizens that are of compulsory school age was } \\
\text { established } \\
\text { The responsibility of the State was established to provide Resource Centers whose specialized role will include provision } \\
\text { for learners with SEN who would benefit more from being in these centers than in mainstream schools for as long needed } \\
\text { based on the SEN } \\
\text { SEN is defined as a case where a child has special difficulties of physical, intellectual, sensory, or psychological nature } \\
\text { The Colleges of State Schools were created that ensure all students that belong to the schools in a certain College (in this } \\
\text { context, it is a set geographical area in Malta) receive their education in a continuous and smooth process from an early } \\
\text { age to the end of compulsory education, taking their potential into account }\end{array}$ \\
\hline & 2013 & Mental Health Act & $\begin{array}{l}\text { Established several rights for people with mental conditions, namely the rights to: } \\
\text { (1) Exercise all civil, social, educational, and cultural rights (among others) equally to people not covered by this Act } \\
\text { (2) Receive treatment that addresses their needs holistically using a multidisciplinary care plan } \\
\text { (3) Receive treatment in the least restrictive manner, as well as in the least restrictive environment } \\
\text { (4) Have their dignity fully respected } \\
\text { (5) Have access to any health, educational, or social service to aid their situation; and } \\
\text { (6) Have the equal opportunities and protection from discrimination as people that do not fall under the scope of this Act }\end{array}$ \\
\hline & 2016 & $\begin{array}{l}\text { Persons within the Autism Spectrum } \\
\text { (Empowerment) Act }\end{array}$ & $\begin{array}{l}\text { Established a Council that tends to the needs of autistic people in society and outlined their tasks and responsibilities: } \\
\text { (1) Give advice on enabling people with autism to learn life- and social development skills to facilitate their optimal and } \\
\text { equal participation in education } \\
\text { (2) Facilitating training for parents and people who interact regularly with children with autism } \\
\text { (3) Raising awareness in society in an attempt to create understanding and acceptance } \\
\text { The goals of the Council are also outlined: } \\
\text { (1) To empower people with autism by providing for their health, well-being, education, and participation in all aspects of } \\
\text { society and for the improvement of their living conditions } \\
\text { (2) To encourage early identification of autism in children in order to provide appropriate early intervention services to } \\
\text { achieve optimal participation in their home and education } \\
\text { (3) To maximize the potential for children with autism through their personal autonomy and active citizenship; and } \\
\text { (4) To identify the socio-economic,psycho-educational and health needs of people with autism with a view for } \\
\text { Government to address these needs }\end{array}$ \\
\hline \multirow{6}{*}{ Cyprus } & 1979 & Special Education Act & Legitimized segregation and put special schools under the umbrella of Ministry of Education and Culture \\
\hline & $\overline{1999 / 2001}$ & $\begin{array}{l}\text { Education and Training of Children with } \\
\text { Special Needs Act }\end{array}$ & $\begin{array}{l}\text { Made changes to the "culture" of educating children with disabilities solely in special schools, which was not a common } \\
\text { viewpoint that was shared by the community of education regarding these children: } \\
\text { (1) Regulation of the detection of children with SEN } \\
\text { (2) Development of a personal education plan, along with its assessments } \\
\text { (3) Placement in appropriate educational institutions } \\
\text { (4) Continuous evaluation of the progress of the child } \\
\text { Special education environments were equipped to provide children with disabilities with a positive learning environment, } \\
\text { due to numerous operational structures and provisions which support them } \\
\text { Such provisions included speech therapists, special education teachers, teaching assistants, assistive technology, } \\
\text { individualized teaching, extra budgets and materials and specially designed resource rooms } \\
\text { All children with SENhave the right to be educated and trained in the mainstream public schools without regard of the } \\
\text { severity of their needs } \\
\text { Special staff should also be provided for any extra help and support needed in the classroom for the child }\end{array}$ \\
\hline & 2001 & $\begin{array}{l}\text { Rules on the Education and Training of } \\
\text { Children with Disabilities } \\
\text { Early Detection Mechanism for Children with } \\
\text { Special Needs Regulation }\end{array}$ & $\begin{array}{l}\text { These two policies combined regulate the implementation of the 1999/2001 Education and Training of Children with } \\
\text { Special Needs Act }\end{array}$ \\
\hline & 2003 & $\begin{array}{l}\text { Code of Practice for Referring Children with } \\
\text { Special Needs to the Special Education and } \\
\text { Training District Committees }\end{array}$ & $\begin{array}{l}\text { Motivating schools to work with students believed to have 'special needs' prior to referring them for assessment } \\
\text { Work on so called the detection mechanism for early detection of children with SEN } \\
\text { Introduced a five-staged assessment procedure and takes about } 5 \text { months for the procedure to be finalized }\end{array}$ \\
\hline & 2014 & $\begin{array}{l}\text { Amendment to the } 1999 / 2001 \text { Education and } \\
\text { Training of Children with Special Needs Act }\end{array}$ & $\begin{array}{l}\text { Main policy framework remained the same } \\
\text { Explicitly stated the commitment of the Ministry of Education and Culture to from integration towards an inclusive } \\
\text { education system }\end{array}$ \\
\hline & \begin{tabular}{l|l}
2016 \\
2018 \\
2019
\end{tabular} & Primary Education Circulars & $\begin{array}{l}\text { Teachers were invited to show interest in and be educated on issues related to information, education, and inclusion of } \\
\text { children with autism }\end{array}$ \\
\hline \multirow{2}{*}{ Luxembourg } & $\overline{1973}$ & $\begin{array}{l}\text { Law establishing institutes and services of } \\
\text { differentiated education }\end{array}$ & $\begin{array}{l}\text { Implementation of differentiated education: any child that could not participate in mainstream or special education } \\
\text { because of his or her mental particularities would receive an education that corresponded to his or her condition } \\
\text { Regardless of the condition of a child, they would still be subject to compulsory education } \\
\text { A framework for differentiated education institutions was set up to adhere to in terms of workforce to assist children with } \\
\text { SEN, included the assistance of psychologists, special education teachers, primary school teachers, other educators and } \\
\text { instructors, and nursery school teachers }\end{array}$ \\
\hline & 1988 & $\begin{array}{l}\text { Grand-Ducal Decree establishing an Institute } \\
\text { for Autistic and Psychotic Children }\end{array}$ & $\begin{array}{l}\text { A special institute for children with autism and children that suffer from psychoses that was also part of differentiated } \\
\text { education } \\
\text { Established a framework to be used for the guidance of children with autism in the institute, based on the } 1973 \text { Law }\end{array}$ \\
\hline
\end{tabular}




\begin{tabular}{|c|c|c|}
\hline 1989 & Law of 10 January 1989 & $\begin{array}{l}\text { Updated the required staff to be available in the institute } \\
\text { Compared to the previous iteration, a more multidisciplinary approach is introduced, involving not only psychologists } \\
\text { and various kinds of teachers, but also physiotherapists, speech therapists, social workers, and occupational therapists, } \\
\text { thus significantly improving the variety of SEN that could be addressed. }\end{array}$ \\
\hline 1994 & Law of 28 June 1994 & $\begin{array}{l}\text { Resulted in an environment where a child would always have a place in the education system, preferably in mainstream } \\
\text { education, followed by special education, and lastly differentiated education } \\
\text { Made amendments to the Education Law of } 1912 \text {, where it was updated to try to include every child in mainstream } \\
\text { education along with general efforts that need to be made in order to facilitate this inclusion where possible }\end{array}$ \\
\hline 2009 & Law on compulsory education & $\begin{array}{l}\text { Every child living aged three years or over is entitled to a school education that contributes to his or her development } \\
\text { Schools should promote the development of children, their creativity, and their confidence in their abilities } \\
\text { Schools should teach values that based on the UDHR } \\
\text { Every child that is over the age of four before } 1 \text { September is obliged to attend school. This obligation then extends over } \\
\text { the next twelve years } \\
\text { Children with SEN can meet the compulsory education requirement through differentiated education according to their } \\
\text { personal needs }\end{array}$ \\
\hline 2009 & Law on the organisation of basic education & $\begin{array}{l}\text { School inclusion commissions were introduced } \\
\text { Their goals were defined as to define the care of children in education } \\
\text { The file that the commissions draft on the children with SEN include a diagnosis of the SEN, the aid allocated to the child, } \\
\text { and an individualized care plan } \\
\text { The individualized care plan may consist of } \\
\text { (1) adaptation of classroom instruction provided by the teacher in collaboration with the pedagogics team } \\
\text { (2) classroom assistance for the teaching staff by members of the related multi-professional team for the intervention } \\
\text { (3) a temporary stay in another class for the purpose of learning certain subjects } \\
\text { (4) teaching in a differentiated education class; or } \\
\text { (5) education in a school or specialized institution in Luxembourg or abroad }\end{array}$ \\
\hline 2018 & $\begin{array}{l}\text { Law establishing Centers of Competence in } \\
\text { Specialized Psycho-Pedagogy for Inclusive } \\
\text { Education }\end{array}$ & $\begin{array}{l}\text { These centers have two goals in order to guarantee the right to education and training for children with SEN: } \\
\text { (1) At the level of personal development of the child with SEN, they provide early support and support for early } \\
\text { intervention, they establish specialized diagnoses, and they make recommendations regarding the aids and provisions } \\
\text { that are to be allocated to the child to ensure uptake in the education system } \\
\text { (2) At the school level, the centers are to contribute to the development of ministerial guidelines and recommendations } \\
\text { regarding the education of children with SEN, while also promoting awareness regarding the matter }\end{array}$ \\
\hline 2018 & $\begin{array}{l}\text { Grand-Ducal Regulation on the Center for the } \\
\text { Development of Children and Young People } \\
\text { with Autism Spectrum Disorder }\end{array}$ & $\begin{array}{l}\text { In order to fulfil the goals set in the } 2018 \text { Law, a certain infrastructure is required in every Center for Children and Youth } \\
\text { with Autism Spectrum Disorder: } \\
\text { (1) The teaching unit has at least one teacher or specialized teacher for every two children with SEN; and } \\
\text { (2) the diagnostic, counseling, and monitoring unit is required to have at least one social scientist per } 35 \text { children with } \\
\text { SEN, at least one humanities expert per } 20 \text { children with SEN, and at least one expert social scientist per } 70 \text { children with } \\
\text { SEN }\end{array}$ \\
\hline 1996 & Pre-School Institutions Act & $\begin{array}{l}\text { Children with SEN are defined as in need of personalized program during pre-school with supplementary professional } \\
\text { assistance or personalized programs }\end{array}$ \\
\hline 1996 & Primary School Act & $\begin{array}{l}\text { Aim of primary education: } \\
\text { (1) ensuring universal education of sufficient quality for the entire population } \\
\text { (2) promoting the coherent physical, emotional, cognitive, and social development of an individual, taking individual } \\
\text { developmental capacities into account; and } \\
\text { (3) enabling the student's personal development according to his interests and abilities }\end{array}$ \\
\hline
\end{tabular}

Described what is considered a child with SEN, namely a child that needs an adapted implementation of the primary school program with additional professional assistance

Emphasised the right of a child with SEN to access mainstream primary education

\begin{tabular}{lll}
\hline 1996 & Gymnasium Act & A child with SEN can adjust the performance of his/her duties based on individual capabilities \\
\hline 1997 & Decree on norms and standards for the & Chapter 8 - How various educational programs are supposed to be adapted when educating children with SEN \\
education and training of children and youth & Primary School Programs: \\
with special needs & (1) Class sizes of the departments that involve children with intellectual disabilities are supposed to start with a \\
& maximum of 8 children per class in grades 1 and 2,10 children in grades 3 through 5 , and 12 pupils in grades 6 through 8 \\
& $\begin{array}{ll}\text { (2) Classes for children with behavioural or personality disorders are supposed to be no larger than } 8 \text {, while class sizes for } \\
\text { children with multiple disorders are supposed to be no larger than } 5 \text { and } 8 \text { for grades } 1 \text { and } 2 \text {, and } 3 \text { through } 8 \text { respectively }\end{array}$ \\
& Secondary Schools:
\end{tabular}

Secondary Schools

Class sizes were set to a standard of 10 children

Special Education Programs per education level:

Each education level reflects three years of education (level 1 is the first three years, 2 the next three, and so on up to level

5)

(1) For departments that covered education programs for children with moderate to severe mental conditions, the firs

level should only have 6 children per class, the second level 7 children, and the third level 8

(2) Special program classes for children with severe or multiple mental conditions should consist of 5 children at the first

level, 6 at the second, and 7 at the third

\begin{tabular}{|c|c|c|}
\hline 2001 & $\begin{array}{l}\text { Decree amending and supplementing the Decree } \\
\text { on norms and standards for the education and } \\
\text { training of children and youth with special } \\
\text { needs }\end{array}$ & $\begin{array}{l}\text { An amendment was made to the class sizes of secondary schools set out in the Decree on norms and standards for the } \\
\text { education and training of children and youth with special needs of } 1997 \text { : } \\
\text { (1) The standard size for groups in which a special program is implemented is } 8 \text { children } \\
\text { (2) This number could be reduced if the level and nature of the SEN of the children demand as such down to a minimum of } \\
4\end{array}$ \\
\hline 2001 & Organization and Financing of Education Act & $\begin{array}{l}\text { Set out goals of the Slovenian education system: } \\
\text { (1) Ensuring the optimal development of the individual irrespective of gender, social and cultural background, religion, } \\
\text { national affiliation, or physical and mental constitution } \\
\text { (2) Providing education and training that corresponds to the stage of development and the life of an individual } \\
\text { (3) Ensuring equal opportunities for education and training in areas with special development problems; and } \\
\text { (4) Ensuring equal opportunities for raising and educating children, adolescents and adults with special needs } \\
\text { Regular and modified educational programs for children and adolescents with SEN were considered publicly available } \\
\text { programs for evervone that required it to use }\end{array}$ \\
\hline 2014 & $\begin{array}{l}\text { Decree on the adoption of the adapted primary } \\
\text { school programme with equivalent education } \\
\text { standard for children with autistic disorders }\end{array}$ & Introduced a tailored primary school program for children with autism with equivalent educational standards \\
\hline 2016 & $\begin{array}{l}\text { Foundation for children and adults with autism } \\
\text {-ZORA }\end{array}$ & $\begin{array}{l}\text { The purpose of this institution was to provide financial support that are important to the treatment of children with autism } \\
\text { and that are not provided by the public sector (e.g. early therapeutic treatment, caring for a child's education) }\end{array}$ \\
\hline 2016 & Protection against Discrimination Act & $\begin{array}{l}\text { Discrimination on basis of disability is prohibited } \\
\text { This prohibition applied to the area of education }\end{array}$ \\
\hline 2016 & $\begin{array}{l}\text { Rules on home education of children with } \\
\text { special needs at primary school level }\end{array}$ & $\begin{array}{l}\text { Sett out the groups of pupils that these rules apply to, which include children with moderate and severe mental conditions } \\
\text { Sets out the conditions under which a child that falls in this category can be homeschooled: } \\
\text { (1) The education at home adequate. This is considered the case a provider of home-based education is available that } \\
\text { fulfills the conditions for the implementation of publicly available programs for children with special needs, as well as } \\
\text { equipment or didactic devices necessary for achieving the objectives and standards of knowledge specified in the } \\
\text { curricula; and } \\
\text { (2) Due to deficiencies, obstacles, or a sudden deterioration of the state of health, the student can no longer attend classes, } \\
\text { the school, or institution in which the student is enrolled. } \\
\text { Before a decision on home schooling is made, a guidance committee is required to review the case and give a final } \\
\text { decision on the matter. }\end{array}$ \\
\hline 2018 & $\begin{array}{l}\text { Resolution on the National Mental Health } \\
\text { Program (2018-2028) }\end{array}$ & $\begin{array}{l}\text { Literacy and awareness with regards to mental health should be increased and steps towards stigmatization should be } \\
\text { taken } \\
\text { This could partially be achieved by the inclusion of the content of mental health in all levels of education }\end{array}$ \\
\hline
\end{tabular}




\section{Supplementary File 2}

\section{Malta}

1. Maltese Ministry for Justice, Culture, and Local Government. Education Act (Cap. 327). 1988. Available from:

http://www.justiceservices.gov.mt/DownloadDocument.aspx?app=lom\&itemid=8801\&l= 1

2. Maltese Ministry for Justice, Culture, and Local Government. Equal Opportunities (Persons with Disability) Act (Cap. 413). 2000. Available from: http://www.justiceservices.gov.mt/DownloadDocument.aspx?app=lom\&itemid=8879\&l= 1

3. Maltese Ministry for Justice, Culture, and Local Government. Mental Health Act (Cap. 525). 2013. Available from:

http://www.justiceservices.gov.mt/DownloadDocument.aspx?app=lom\&itemid=11962\&1 $=1$

4. Maltese Ministry for Justice, Culture, and Local Government. Persons within the Autism Spectrum (Empowerment) Act (Cap. 557). 2016. Available from: http://www.justiceservices.gov.mt/DownloadDocument.aspx?app=lom\&itemid=12505\&l $=1$

5. Spiteri L, Borg G, Callus AM, Cauchi J, Sciberras M. Inclusive and Special Education Review. Floriana; 2005 [cited 2019 Aug 22]. Available from: https://education.gov.mt/en/resources/Documents/Policy Documents/inclusive and special education review.pdf

6. Government of Malta. Autism Spectrum Support Team. 2016 [cited 2019 Aug 22]. Available from: https://education.gov.mt/en/education/studentservices/Pages/Inclusive_Education/Autism-Spectrum-Support-Team.aspx

7. Government of Malta. Lenti fuq 1-Iżvilupp ta`Wliedna. 2016 [cited 2019 Aug 22]. Available from: https://education.gov.mt/en/Lenti/Pages/Lenti.aspx

8. Maltese Ministry of Education. Education Act. 2019. Available from: https://legislation.mt/eli/act/2019/29/eng/pdf Accessed 5 July 2020.

\section{Cyprus}

1. Republic of Cyprus. Constitution of Cyprus. 1960. Available from: http://www.cylaw.org/nomoi/arith/1960_1_011_TKS.pdf

2. Phtiaka H. Educating the Other: A Journey in Cyprus Time and Space. In: Policy, 
Experience and Change: Cross-Cultural Reflections on Inclusive Education. Dordrecht: Springer Netherlands; 2008 [cited 2019 Aug 29]. p. 147-61. Available from: http://link.springer.com/10.1007/978-1-4020-5119-7_11

3. Symeonidou S. Parental involvement in education politics: the case of disabled children. Mediterr J Educ Stud. 2007 [cited 2019 Aug 20];12(2):45-67. Available from: https://gnosis.library.ucy.ac.cy/handle/7/38584

4. Cypriot Ministry of Education and Culture. Special Education Act. 1979. Available from: http://www.cylaw.org/nomoi/arith/1979_1_047.pdf

5. N. 113(I)/99. Integration of Children with Special Needs Act. Official Gaz Repub Cyprus. 1999;

6. Jones C, Symeonidou S. The Hare and the Tortoise: a comparative review of the drive towards inclusive education policies in England and Cyprus. Int J Incl Educ. 2017 Jul 3 [cited 2019 Aug 19];21(7):775-89. Available from: https://www.tandfonline.com/doi/full/10.1080/13603116.2017.1283715

7. Cypriot Ministry of Education and Culture. Rules on the Education and Training of Children with Disabilities (186/2001). 2001 [cited 2019 Aug 31]. Available from: http://www.cylaw.org/KDP/data/2001_1_186.pdf

8. Cypriot Ministry of Education and Culture. The Early Detection Mechanism for Children with Special Needs Regulations (185/2001). 2001 [cited 2019 Aug 31]. Available from: http://www.moec.gov.cy/eidiki_ekpaidefsi/nomothesia/peri_mihanismou_kanonismoi_20 01_185_2001.pdf

9. Republic of Cyprus. Education and Training of Children with Special Needs Act (N. 113(I)/1999). Nicosia: Republic of Cyprus; 1999.

10. Hadjikakou K, Petridou L, Stylianou C. The academic and social inclusion of oral deaf and hard-of-hearing children in Cyprus secondary general education: investigating the perspectives of the stakeholders. Eur J Spec Needs Educ. 2008 Feb [cited 2019 Aug 29];23(1):17-29. Available from: http://www.tandfonline.com/doi/abs/10.1080/08856250701791211

11. Liasidou A. Inclusive education policies and the feasibility of educational change: the case of Cyprus. Int Stud Sociol Educ. 2007 Dec [cited 2019 Aug 23];17(4):329-47. Available from: http://www.tandfonline.com/doi/abs/10.1080/09620210701666972

12. Cypriot Ministry of Education and Culture. Code of Practice for Referring Children with Special Needs to the Special Education and Training District Committees. 2003.

13. Cypriot Ministry of Education and Culture. Primary Education Circulars. 2019. 
14. Cypriot Ministry of Education and Culture. Primary Education Circulars. 2018. Available from:

http://www.pi.ac.cy/pi/files/anakoinoseis/2018_2019/20190619_proairetika_diagnosi_ana gkon.pdf

15. Cypriot Ministry of Education and Culture. Primary Education Circulars. 2016. Available from: http://www.pi.ac.cy/pi/files/anakoinoseis/2015_2016/20160610_diimero_ekp.pdf

16. Symeonidou S. Initial teacher education for inclusion: a review of the literature. Disabil Soc. 2017 Mar 16 [cited 2019 Aug 20];32(3):401-22. Available from: https://www.tandfonline.com/doi/full/10.1080/09687599.2017.1298992

17. Symeonidou S, Mavrou K. Problematising disabling discourses on the assessment and placement of learners with disabilities: can interdependence inform an alternative narrative for inclusion? Eur J Spec Needs Educ. 2019 Apr 25 [cited 2019 Aug 20];1-15. Available from: https://www.tandfonline.com/doi/full/10.1080/08856257.2019.1607661

\section{Luxembourg}

1. Luxembourgian Ministry of National Education. Act of 5 August 1963 on the reform of pre-school education and primary education. 1963. Available from: http://legilux.public.lu/eli/etat/leg/loi/1963/08/05/n4/jo

2. Luxembourgian Ministry of National Education. Law of 14 March 1973 establishing institutes and services of differentiated education. 1973. Available from: http://legilux.public.lu/eli/etat/leg/loi/1973/03/14/n1/jo

3. Luxembourgian Ministry of National Education. Grand-Ducal Decree of 4 March 1988 establishing an Institute for Autistic and Psychotic Children. 1988. Available from: http://legilux.public.lu/eli/etat/leg/agd/1988/03/04/n1/jo

4. Luxembourgian Ministry of National Education. Law of 10 January 1989 on 1. the resumption of differentiated education centers and services in certain municipalities, 2. amendment of the law of 14 March 1973 establishing institutes and educational services differentiated, 3. amendment of the law of 16. 1989. Available from: http://www.men.public.lu/fr/legislation/education-nationale/eleves-specifiques/ch6-loi10-janvier-89.pdf

5. Luxembourgian Ministry of National Education. Law of 28 June 1994 amending and supplementing (a) the amended law of 10 August 1912 concerning the organization of primary education; (b) the amended Act of 14 March 1973 establishing differentiated education institutes and services; for the participatio. 1994. Available from: 
http://legilux.public.lu/eli/etat/leg/loi/1994/06/28/n1/jo

6. Luxembourgian Ministry of National Education. Law of 6 February 2009 on compulsory education. 2009 [cited 2019 Feb 14]. Available from: http:/legilux.public.lu/eli/etat/leg/trep/2009/09/03/n1/jo

7. Luxembourgian Ministry of National Education. Law of 6 February 2009 on the organization of basic education. 2009 [cited 2019 Feb 14]. Available from: http://legilux.public.lu/eli/etat/leg/trep/2014/09/04/n2/jo

8. Luxembourgian Ministry of National Education. Law of 20 July 2018 establishing Centers of Competence in Specialized Psycho-Pedagogy for Inclusive Education. 2018. Available from: http://legilux.public.lu/eli/etat/leg/loi/2018/07/20/a664/jo

9. Luxembourgian Ministry of National Education. Grand-Ducal Regulation of 7 September 2018 on the Center for the Development of Children and Young People with Autism Spectrum Disorder. 2018. Available from: http://legilux.public.lu/eli/etat/leg/rgd/2018/09/07/a806/jo

\section{Slovenia}

1. National Assembly of the Republic of Slovenia. Pre-School Institutions Act. 1996. Available from: http://www.pisrs.si/Pis.web/pregledPredpisa?id=ZAKO447

2. National Assembly of the Republic of Slovenia. Primary School Act. 1996. Available from: http://www.pisrs.si/Pis.web/pregledPredpisa?id=ZAKO448

3. National Assembly of the Republic of Slovenia. Gymnasium Act. 1996. Available from: http://www.pisrs.si/Pis.web/pregledPredpisa?id=ZAKO450

4. Slovenian Ministry of Education and Sport. Decree on norms and standards for the education and training of children and youth with special needs. 1997. Available from: http://www.pisrs.si/Pis.web/pregledPredpisa?id=ODRE1448

5. Slovenian Ministry of Education and Sport. Special Education Program. 2014. Available from:

http://www.mizs.gov.si/delovna_podrocja/direktorat_za_predsolsko_vzgojo_in_osnovno_ solstvo/izobrazevanje_otrok_s_posebnimi_potrebami/programi/posebni_program_vzgoje _in_izobrazevanja/

6. Slovenian Ministry of Education and Sport. Decree amending and supplementing the Decree on norms and standards for the education and training of children and youth with special needs. 2001. Available from: http://www.pisrs.si/Pis.web/pregledPredpisa?id=ODRE1656 
7. National Assembly of the Republic of Slovenia. Organization and Financing of Education Act (official consolidated text). 2001. Available from: http://www.pisrs.si/Pis.web/pregledPredpisa?id=ZAKO3592

8. National Assembly of the Republic of Slovenia. Disabled Persons Organizations Act. 2002. Available from: http://www.pisrs.si/Pis.web/pregledPredpisa?id=ZAKO1460

9. Slovenian Ministry of Education and Sport. Rules on norms and standards for the implementation of educational programs for children with special needs in elementary schools with an adapted program and institutions for the education and training of children with special needs. 2005. Available from: https://www.uradni-list.si/glasilouradni-list-rs/vsebina/2005-01-3293?sop=2005-01-3293

10. National Assembly of the Republic of Slovenia. Equalization of Opportunities for Persons with Disabilities Act. 2010. Available from: http://www.pisrs.si/Pis.web/pregledPredpisa?id=ZAKO4342

11. National Assembly of the Republic of Slovenia. Guidance of Children with Special Needs Act. 2011. Available from: http://www.pisrs.si/Pis.web/pregledPredpisa?id=ZAKO5896

12. Slovenian Ministry of Education,Science and Sport,. Rules on the organization and work methods of commissions for the placement of children with special needs. 2013. Available from: http://www.pisrs.si/Pis.web/pregledPredpisa?id=PRAV11834

13. Slovenian Ministry of Labor, Family and Social Affairs and Equal Opportunities,. Rules on criteria for claiming rights for children in need of special care. 2014. Available from: http://www.pisrs.si/Pis.web/pregledPredpisa?id=PRAV12241

14. Slovenian Ministry of Education, Science and Sport,. Decree on the adoption of the adapted primary school programme with equivalent education standard for children with autistic disorders. 2014. Available from: http://www.pisrs.si/Pis.web/pregledPredpisa?id=ODRE2283

15. Slovenian Ministry of Labor, Family, Social Affairs and Equal Opportunities,. Foundation for children and adults with autism - ZORA. 2016. Available from: http://www.pisrs.si/Pis.web/pregledPredpisa?id=ODLB1397

16. Slovenian Ministry of Labor, Family, Social Affairs and Equal Opportunities,. Protection Against Discrimination Act. 2016. Available from: http://www.pisrs.si/Pis.web/pregledPredpisa?id=ZAKO7273

17. Slovenian Ministry of Health. Resolution on the national mental health programme 20182028. 2018. 


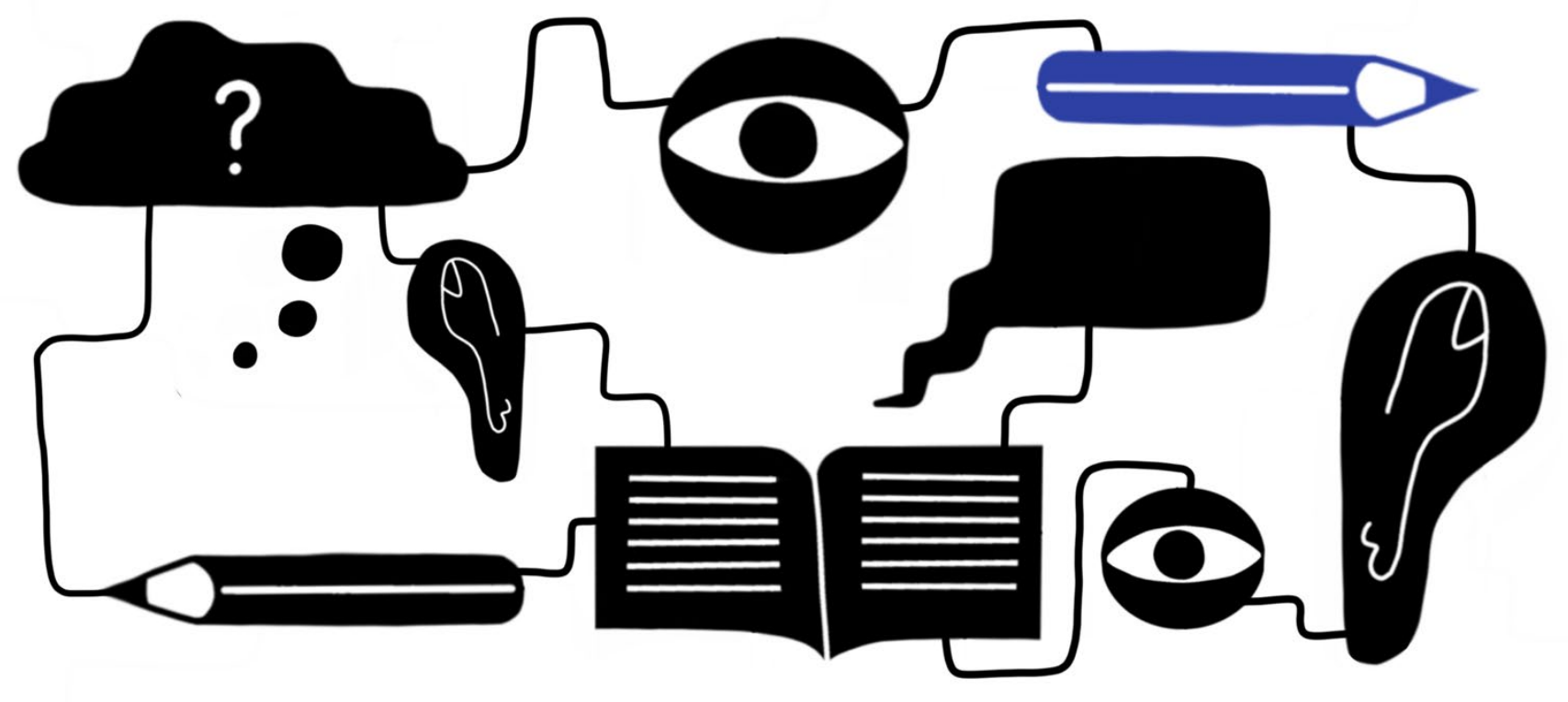

\section{Chapter Five}

Baltic States and Former Soviet Influence

\section{Published as:}

van Kessel, R., Dijkstra, W., Prasauskiene, A., Villeruša, A., Brayne, C., Baron-Cohen, S., Czabanowska, K., \& Roman-Urrestarazu, A. Education, Special Needs, and Autism in the Baltic States: Policy Mapping in Estonia, Latvia, and Lithuania. [Accepted August 2020 in Frontiers in Education] 


\begin{abstract}
The Soviet occupation of the Baltic States followed by joining the United Nations (UN) and European Union make these countries an interesting point of comparison in the development of autism and education policy. This study investigates how policies changed following the transition and how the right and access to education are facilitated for autistic children by performing a path dependence analysis. All Baltic States created new education policies following the transition out of the Soviet era, with their accession to the UN and their appetite to follow internationally available guidance. The right to education for all children in was adopted in all education systems. Education facilities for children with disabilities were implemented in all countries. Afterwards, all countries started towards the development of more inclusive systems. Nevertheless, the majority of policies did not specify for autism, yet covered special education needs in general. A development in Latvia should be noted, where various special education needs are outlined in national policy, along with provisions and professional assistance required to address them in mainstream or special classrooms. Ultimately, education policy flourished after the transition. Their development caught up to other European Union countries and they are currently working on implementing inclusive education.
\end{abstract}

\title{
Keywords
}

Autism, Special Education Needs, Policy, Baltics, Special Education, Inclusive Education 


\section{Introduction}

The Baltic States (a geopolitical term for Estonia, Latvia, and Lithuania) were occupied by the Soviet Union until late 1980s, at which point their independence became inevitable as the Soviet Union began to dissolve (Beissinger, 2009). This ultimately led to a transitional period in which the Soviet Union collapsed and the individual Baltic States were re-established (Van Elsuwege, 2008; Kerikmäe et al., 2018). The Baltic States proceeded to each join the United Nations (UN) in 1991 and the European Union (EU) in 2004 (European Union, 2020; United Nations, 2020).

With the accession to the UN and EU respectively, the Baltic States were introduced to the values set out in international documents, such as the Universal Declaration of Human Rights (UDHR), the Salamanca Statement and later the Convention on the Rights of Persons with Disabilities (CRPD) (United Nations, 1948, 2006; UNESCO, 1994). In these documents, the right to education for children with special education needs (SEN) is well established, including autistic children. However, endorsing this right with respect to access to education for autistic children in the EU has been complicated (Carroll et al., 2017). With a male-tofemale ratio between $3: 1$ and $4: 1$, autism affects roughly $1 \%$ of the population and around 1 in 160 children (Lai et al., 2014; Loomes et al., 2017; World Health Organisation, 2019). Autistic people may be more susceptible to serious health and other functional difficulties that may cause financial problems for families and caregivers and the condition can still carry substantial stigma (Howlin et al., 2004; Knapp et al., 2009; van Heijst and Geurts, 2015; World Health Organisation, 2017). To address these circumstances and improve the inclusion and quality of life of the autism community across Europe, the implementation of fundamental rights of education is crucial (European Commission, 2010; Hehir et al., 2016).

Prior work by the European Consortium for Autism Researchers in Education (EDUCAUS) established that the implementation of the UDHR and CRPD had great impact in the development of the education systems with regards to autistic children (Roleska et al., 2018; van Kessel et al., 2019a, 2019b). In these analyses, it was outlined that the UDHR, CRPD, and other UN policies set out values and directions for education systems to develop in. For instance, the UDHR set out the right to education for everyone. Subsequently, facilities where children with SEN could be educated were implemented in the countries under study. The Salamanca Statement and CRPD both emphasised the importance of developing inclusive education, which the countries under study subsequently started to develop. 
This paper will extend the policy mapping project of EDUCAUS into the Baltic States. Even though Estonia (1.3 million inhabitants), Latvia (1.9 million inhabitants), and Lithuania (2.8 million inhabitants) represent only 6 million EU citizens and roughly $1 \%$ of the EU population (Eurostat, 2018), their shared history with the Soviet Union and subsequent development under the influence of the UN and EU make them an interesting point of comparison to see how a transition of ideology impacts the development of the respective education systems. More specifically, this study has two aims: (1) investigate what effects the transition from the Soviet era to the UN had on special education policy for autistic children; and (2) explore how the education systems have developed in regards to special education and inclusive education for autistic children.

\section{Methods}

Since the analysis in this paper focuses on the interaction of different policy layers in a temporal manner, a path dependence analysis was used. This methodology enables us to see policy creation as historical sequences and patterns and identify path dependence (Mahoney, 2000). The usage of this methodology is consistent with and validated by previous work of EDUCAUS (Roleska et al., 2018; van Kessel et al., 2019a, 2019b). Data were gathered through the use of a scoping review, which allows for rapid mapping of the key concepts that underpin a wide research area and is particularly suitable for exploring complex matters that have not yet been comprehensively reviewed (Arksey and O'Malley, 2005; Levac et al., 2010). Due to there not being a comprehensive data source in the EU on autism and SEN policy, a modular approach to legislative and policy work was adopted to analyse the different educational policy environments (Estonian, Latvian, and Lithuanian). This approach adopted the systematic search strategy that is outlined in the PRISMA framework by establishing clear eligibility criteria, defining information sources, reporting the complete search query, and outlining the data collection process and the data items that were looked for (Moher et al., 2009). Risk of bias assessment was not translated into this methodology, since this work uses policy data. The findings were also reported based on the PRISMA framework by reporting the exact number of documents included per country, giving an overview of the individual documents, and a synthesis of the documents (Moher et al., 2009).

\section{Eligibility Criteria}

Eligibility criteria were similar to previous work by EDUCAUS for consistency purposes (Roleska et al., 2018; van Kessel et al., 2019a, 2019b). Documents that fit the inclusion 
criteria should conform to (1) having a scope relating to the right to education, national education system, disability laws, inclusion, or special education needs; (2) aiming at children under 18 years; (3) being drafted by a governmental institution; and (4) being published after 1948. Constitutions were always included and no language limitations were set. Non-governmental policies and actions were excluded. It has to be noted that, in previous works by EDUCAUS, it became evident that autism-specific policy is not always present. In case this happens, general SEN or education policy was analyzed instead and the implications for the autism community were discussed.

\section{Data Collection and Search Strategy}

Similar to previous work (Roleska et al., 2018; van Kessel et al., 2019a, 2019b), the data collection consisted of five steps in which governmental policy repositories formed the primary source of data collection: (1) review and extract relevant policies and legislation that address the right to education of autistic people directly from original governmental sources; (2) develop a multi-layered search strategy for scientific databases (PubMed and Google Scholar); (3) merging policy and academic publications according to the eligibility criteria; (4) acquire further information through searching reference lists of key articles; and (5) merge the three searches into one single data repository for the purpose of this scoping review and to compare it to the already mapped policy of the United Nations and the EU for further analysis.

Table 1 shows the governmental policy repositories that were used per country. The search strategy involved searching the full-text for the respective keywords, instead of just titles and abstracts in order to minimize the risk of overlooking policy as a result of inaccurate or incomplete translations. The keywords used for the policy repositories were as follows: autism, disability, special education needs, education, special needs, special education, inclusive education. These were translated into Estonian, Latvian, and Lithuanian respectively and used individually, as combining the keywords in the policy repositories yielded little relevant results. Subsequently, the exact build-up of the search query used for scientific databases is shown in Table 2. The data collection took place between May $23^{\text {rd }}$ and June $13^{\text {th }} 2019$. 
Table 1 The policy repositories used per country

\begin{tabular}{ll}
\hline Country & Link \\
\hline All & http://eur-lex.europa.eu/n-lex/ \\
\hline Estonia & https://www.riigiteataja.ee/index.html \\
\hline Latvia & https://likumi.lv/ \\
& https://www.vestnesis.lv/ \\
\hline Lithuania & http://www3.lrs.lt/dokpaieska/forma_e.htm \\
& https://www.e-tar.lt/portal/en/index \\
\hline
\end{tabular}

Table 2 The build-up of the final search query for academic databases

\begin{tabular}{ll}
\hline & Search Query \\
\hline S1 & inclusion OR education \\
\hline S2 & $\begin{array}{l}\text { autis* OR ASC OR ASD OR disability OR special educational needs OR SEN } \\
\text { OR disab* }\end{array}$ \\
\hline S3 & policy OR legislation OR regulation OR law \\
\hline S4 & Lithuania OR Latvia OR Estonia OR Baltic* \\
\hline Final & $\begin{array}{l}\text { (inclusion OR education) AND (autis* OR ASC OR ASD OR disability OR } \\
\text { special educational needs OR SEN OR disab*) AND (policy OR legislation OR } \\
\text { regulation OR law) AND (Lithuania OR Latvia OR Estonia OR Baltic*) }\end{array}$ \\
\hline
\end{tabular}

\section{Data Analysis}

Gathered data was analyzed using the UN and EU policy data that was mapped in previous EDUCAUS papers (Roleska et al., 2018; van Kessel et al., 2019a). Supplementary File 1 shows an overview of the policy data of the respective policies. As such, the extent to which the values of international policies are integrated in the national policies could be established. To gauge the development of the Baltic education systems after regaining their independence, implementation of the values that were set out in international policy were tracked by reporting on the clusters of policies that accounted for the implementation of international values: (1) the universal right to education laid down in the UDHR; (2) the right for children to receive appropriate treatment consistent with their condition by the Declaration on the Rights of the Child; (3) the right for children with developmental, intellectual, and learning conditions to receive appropriate education to maximize their potential by the Declaration on the Rights of Disabled Persons; and (4) the development of an inclusive education environment as set out by the Salamanca Statement and the CRPD.

\section{Results}

A total of 2861 sources were identified through electronic database searching and four through other sources. Ultimately, 44 sources were included in this scoping review. A PRISMA flowchart illustrates the data selection process in Figure 1. A synthesis of the policy 
data outlining development of the education systems is reported below, while the contents of each individual policy that are used in the synthesis is added in Supplementary File 2.

References to all included policies are included in Supplementary File 3.
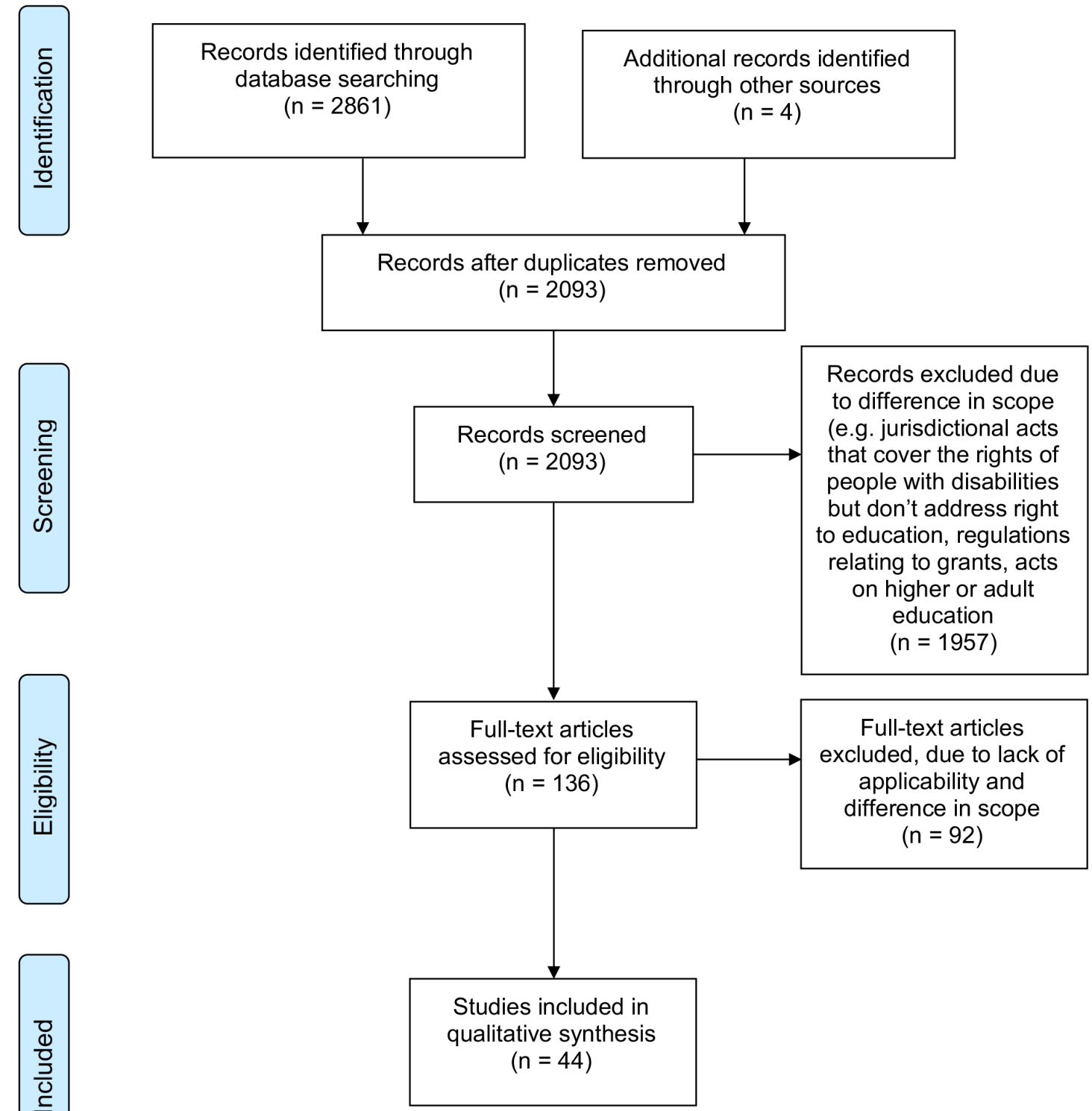

Full-text articles excluded, due to lack of applicability and difference in scope $(n=92)$

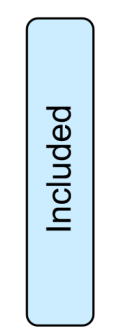

Studies included in $(n=44)$

Figure 1. The PRISMA flowchart depicting the data collection process.

However, since both the Estonian and Latvian databases did not expand on legislation prior to their regained independence, an additional five sources were identified using the nonscientific database 'Google' and added as grey literature in this review. Considering the lack of initial data prior to 1991 in two of the three countries under review and the stated fact that the Soviet Union acted in this time period in all three countries as a federal state, an 
additional sub-chapter is added in the results section covering Soviet federal law on the right to education for autistic children.

\section{The Baltic Soviet Socialist Republics}

The Soviet Union advocated a notion of rights different from the conception of fundamental rights in the West (Patenaude, 2012): Western rights aim to protect citizens and prevent the government from amassing too much power, while Soviet rights were given out and dictated by the government. The right to education and facilities to educate children with SEN in general were implemented - though from a different ideological perspective. Whereas UNbased policies state that their aim is to enable children with SEN to develop themselves to their maximum potential with a focus on autonomy (United Nations, 1975), the Soviet-based policies specifically state that they aimed to develop children with SEN in a way they can do socially useful work (Union of Soviet Socialist Republics, 1973).

\section{Estonia}

The right to education for all children was re-established immediately upon the introduction of the new Estonian constitution in 1992 (Republic of Estonia, 1992). Subsequent policies in the 1990's all shared the common theme of shaping the education system in a way that every child had a place: continuous education was developed for all children, schools were established to give children with SEN a place to follow education and have their needs met timely and adequately, and adapted curricula were formed that were appropriate to the SEN of a child (Republic of Estonia, 1993d, 1993a, 1993b, 1993c). A multidisciplinary advisory committee was also established during this timeframe - which functioned as a guiding body in determining the location and curriculum for children with SEN (Republic of Estonia, 1999b, 1999a). The term 'inclusion' mentioned in this document refers to including children with SEN in the education system rather than mainstream education.

Policies from 2010 onward, however, aimed more at developing inclusive education. Education was organised with the ideology to admit children with SEN into mainstream schools as much as possible (Republic of Estonia, 2010, 2014, 2016, 2018). An updated definition of SEN was introduced, namely a child whose talents, learning difficulties, state of health, disability, behavioral and emotional disturbances, prolonged absence from school or insufficient knowledge of the language of instruction necessitates changes or adjustments; classes for children with SEN that cannot participate in mainstream education were limited in 
their membership numbers, and an acknowledgement was made to adjust mainstream content to the needs of the child with SEN where possible and necessary.

Ultimately, with reference to the educational dimensions of the UN (United Nations Committee on the Rights of Persons with Disabilities, 2016), a system of integration is currently in place. Additionally, it has to be noted that Estonia has not implemented autismspecific policy. Instead, all policies discuss children with SEN in general.

\section{Latvia}

Initially, a segregated approach is described by placing children with SEN in either sanatoriatype schools or educational and upbringing institutions, where they received care and education and, upon graduation, would receive a standard educational document (Republic of Latvia, 1991). This further developed in 1993 when the rights of people with disabilities were established at the national level (Republic of Latvia, 1993), which included the right to appropriate education - involving additional equipment or technical aides - at home and in schools. 1998 saw the introduction of anti-discrimination legislation that applied on the basis of disability (Republic of Latvia, 1998a); the reaffirmation of free, compulsory education for all children in Latvia (Republic of Latvia, 1998a); the establishment of rights specifically for children, including the right to develop according to individual capabilities, as well as the guarantee that professionals are specifically trained to work with children with SEN (Republic of Latvia, 1998b); and the ratification of a new education law that abolished the excluding elements set out in the 1991 iteration by introducing a framework on special education (Republic of Latvia, 1998c). 1999 marked the end of the first group of educationrelated policies by further elaborating on possibilities for education programs for children with SEN (Republic of Latvia, 1999). It is mentioned that mainstream schools can admit children with SEN when they can provide the assistance the child needs - which points to an initial element of integration-inclusion practice.

The second group of education-related policies commenced in 2010 with the introduction of rights for students with SEN at all school levels (Republic of Latvia, 2010). Subsequently, assistant services were introduced for children with SEN, along with requirements that people who would deliver these assistant services should adhere to in terms of their education (Republic of Latvia, 2012a). Pedagogical Medical Commissions were implemented to further streamline the education of children with SEN and promote their integration in mainstream 
education (Republic of Latvia, 2012b). Autism, atypical autism, and Asperger's syndromethe differentiations of autism that were included in the fourth edition of the Diagnostic and Statistical Manual of Mental Disorders (DSM-IV) (American Psychiatric Association, 2000) — were also specifically mentioned as possible diagnoses for children with SEN. A definition on inclusive education was introduced that acknowledged the array of needs that children with SEN can have and calls for inclusion in the education system (Republic of Latvia, 2014). It, however, fails to address the element that is present in the international definition of the unification of education - merging mainstream and special education in a single entity. Special Education Development Centres aimed to provide consultative and methodical support to parents, children and educators in the areas of diagnosis, methodical and pedagogical assistance, and organisation of events (Republic of Latvia, 2016). Finally, specific provisions (i.e. equipment, support measures, and additional staff) that are necessary, preferred, and/or desirable to be implemented in mainstream or special classrooms were set out (Republic of Latvia, 2018). While autism is not specifically mentioned, various cooccurring conditions that appear with autism are listed (Lai et al., 2014), such as visual- and hearing impairment, learning disabilities, and mental health problems.

\section{Lithuania}

Development of the education system in Lithuania happened in two parts. Firstly, in the period of 1991-2002, the constitution instantly implemented compulsory education for all children until the age of 18 (Republic of Lithuania, 1992). Simultaneously, the right to education for people with disabilities was established (Republic of Lithuania, 1991b), as well as the option for children with SEN to be educated in special classes in mainstream schools (Republic of Lithuania, 1991a). The structure for special education was elaborated, along with the implementation of a definition for SEN (Republic of Lithuania, 1998). Special education, in a Lithuanian context, is not characterised by a segregated approach — rather by an approach that is mostly similar to integration. Autism was also categorised under the umbrella of 'emotional, behavioural, and social developmental disorders' (Republic of Lithuania, 2002).

The second period, ranging from 2011 until present, commenced with an update of the purpose and framework of special education - now aiming to aid children with SEN to develop their competences and skills through education and involving technical and professional assistance (Republic of Lithuania, 2011a). Autism was recategorized under the 
umbrella of 'various developmental disorders' and a distinction was made between the several types of autism that were previously outlined in the DSM-IV (American Psychiatric Association, 2000; Republic of Lithuania, 2011b). Remaining policies in this period all aimed at establishing values and objectives to improve education and to develop education further from an integrative to an inclusive system.

\section{Discussion}

The aim of this path dependence analysis was to extend the EDUCAUS policy mapping project into the Baltic States and (1) investigate what effects the transition from the Soviet era to the UN had on special education policy for autistic children; and (2) explore how the education systems have developed in regards to special education and inclusive education for autistic children. By searching the policy repositories of the respective Baltic States, all relevant national policies on the provision of education to autistic pupils and their right to education were inspected.

Firstly, we found a shift from the value system set out by the Soviet Union to the value system outlined by the UN in all three Baltic States after regaining their independence and joining the UN (Republic of Latvia, 1990, 1991; Republic of Estonia, 1993c). They showed willingness to follow internationally available guidance, as is seen by their reformations of the education systems to introduce and further enhance the education of children with SEN soon after their accession to the UN and their efforts to start implementing inclusive education after the ratification of the CRPD (Republic of Estonia, 2010; Republic of Latvia, 2014; Republic of Lithuania, 2014). This is consistent with other literature where it is explained that the Baltic States showed willingness to adopt new policy influences after the collapse of the Soviet Union (Van Elsuwege, 2008; Kerikmäe et al., 2018). They were also willing to make the changes necessary to join the EU during their accession process (Grigas et al., 2013).

Secondly, we found that the Baltic States specifically adopted the values set out in the UDHR, Salamanca Statement, CRPD, and other UN documents. Particularly, we found that the universal right to education as laid down in the UDHR was unanimously implemented (Republic of Lithuania, 1991a; Republic of Estonia, 1992; Republic of Latvia, 1998a). The right for children to receive appropriate treatment consistent with their condition by the Declaration on the Rights of the Child and the right for children with developmental, 
intellectual, and learning conditions to receive appropriate education to fully develop themselves as set out by the Declaration on the Rights of Disabled Persons were also both integrated in all three countries (Republic of Estonia, 1993c; Republic of Latvia, 1998b, 1998c; Republic of Lithuania, 1998). Development of inclusive education started in all three countries as well, initiating the uptake of children with SEN in their mainstream systems (Republic of Estonia, 2010; Republic of Latvia, 2014; Republic of Lithuania, 2014), though none have implemented a system of full inclusion yet. This is coherent with the development of other education systems across the EU (e.g. Denmark, France, Germany, and the Netherlands), where a similar level of development of the education system was found (Roleska et al., 2018; van Kessel et al., 2019b, 2019a). One noteworthy development in Latvia is the implementation of provisions that should be present in mainstream and special classrooms based on specific forms of SEN, which has only been found in Luxembourg previously (van Kessel et al.) [Forthcoming 2020] and forms a key factor is the development of inclusive education (Peters et al., 2005).

Findings of this paper also further support the findings of a previous EDUCAUS paper, in which the effect of international guidance on small states within the EU was explored (van Kessel et al.) [in press]. Estonia fits their description of a small state, namely "states that not only have a small population size, but also are not in a position to influence the international policy environment on their own and are, by extension, largely dependent on the decisions of larger states and overarching political structures." They explained that, while tension occurs in the field of health policy, the field of education policy, international guidelines tend to be closely translated to national policy. The findings of this paper are in line with this assertion, as the values set out by international guidance have been translated directly to national policy.

From the 39 discussed policies (12 for Estonia, 15 for Latvia, 12 for Lithuania), 35 did not specify for autism $(89.74 \%$; 12 for Estonia [100\%], 14 for Latvia [93.33\%], 9 for Lithuania [75\%]). Instead, they relate to autism in the sense that they discuss children with SEN. While this benefits the autism community by granting them access to the services discussed in the policies, it also points towards a lack of specificity being incorporated in national policy. This is a stark contrast to other EU countries, such as France, Northern Ireland, Spain, and Flanders (Belgium), where specific autism-related policies are implemented to guide how autism should be addressed in those specific countries (Roleska et al., 2018; van Kessel et al., 
2019a). Alternatively, the German-speaking community in Belgium and Luxembourg implemented institutions that are specifically geared towards assisting autistic children (van Kessel et al., 2019a). As such, even though the Baltic States are progressing on par with other EU countries in terms of the development of their education system, specifically addressing autism in national policy is an aspect in which there is still room for improvement. That being said, due to the vast majority of policies focusing on SEN in general, the implications of this study are not limited to autism and can be applied to the wider context of SEN.

This study holds several limitations. Firstly, even though the outcomes of this scoping review are not blindly transferable, the concepts that are discussed can be implemented in other education systems after accounting for local and cultural implications. Secondly, this study involves a policy analysis, meaning it cannot determine how these policies are translated into practice. Thirdly, the national legal databases of Estonia, Latvia, and Lithuania were used in the data search. To use these databases, the search terms had to be translated into the respective languages and the documents had to be translated back to English using machine translation services. In order to account for errors in translation and to ensure completeness of the dataset, country experts were involved to review the data analysis. Fourthly, this paper did not investigate actions taken by non-governmental organisations, which could be used to enhance national policy. Finally, this paper only investigated education policy that pertained to autistic children. As a result, autistic adults that follow education are not included in this analysis, while they may experience similar learning difficulties.

Ultimately, this study provided insight in the SEN policy environment of the Baltic States: Estonia, Latvia, and Lithuania. Path dependency analysis shows the integration of most values of the UDHR, CRPD and other international documents in national legislation. Policies from the Soviet era were all replaced with policies that reflect the values of the UN. Finally, inclusive education has become a guiding factor in the education systems of the countries under study.

\section{Contribution to Field}

Autism is a neurodevelopmental condition that affects approximately $1 \%$ of the population and 1 in 160 children and often causes special education needs during children's development. Since the right and access to education for all children are set out at the United Nations and the European Union level and a particular focus on developing inclusive 
education has emerged in Sustainable Development Goals 4.5 and 4.A, it is important to assess the current situation of education systems. This study provides country-level comparisons and a thorough policy mapping of Estonia, Latvia, and Lithuania. We demonstrate how national policy developments are linked to internationally available guidance. We investigate how autistic children are enabled to attend, follow, and participate in education. We discuss how inclusive education is developed in the countries under study according to available guidance and what factors can improve that development, also referencing previously investigated European countries. Lastly, we emphasize a development in Latvian policy, which establishes specific provisions (both materials and professionals) that should be present in mainstream and special classrooms for special education needs. Even though this study is initially focused on autism, its findings are also applicable to SEN in general due to the volume of general SEN policies.

\section{Reference list}

American Psychiatric Association (2000). Diagnostic and statistical manual of mental disorders (4th ed., Text Revision). Washington, DC: American Psychiatric Association. Arksey, H., and O’Malley, L. (2005). Scoping studies: towards a methodological framework. Int. J. Soc. Res. Methodol. 8, 19-32. doi:10.1080/1364557032000119616.

Beissinger, M. (2009). "The intersection of Ethnic Nationalism and People Power Tactics in the Baltic States," in Civil resistance and power politics: the experience of non-violent action from Gandhi to the present. (Oxford: Oxford University Press).

Carroll, J., Bradley, L., Crawford, H., Hannant, P., Johnson, H., and Thompson, A. (2017). SEN support: A rapid evidence assessment.

European Commission (2010). European Disability Strategy 2010-2020: A Renewed Commitment to a Barrier-Free Europe. doi:10.1017/CBO9781107415324.004.

European Union (2020). Countries. Available at: https://europa.eu/european-union/abouteu/countries\#tab-0-1 [Accessed April 30, 2020].

Eurostat (2018). Population change - Demographic balance and crude rates at national level. Available at: http://appsso.eurostat.ec.europa.eu/nui/show.do?dataset=demo_gind\&lang=en [Accessed April 30, 2018].

Grigas, A., Kasekamp, A., Maslauskaite, K., and Zorgenfreija, L. (2013). The Baltic States in the EU: Yesterday, Today and Tomorrow.

Hehir, T., Grindal, T., Freeman, B., Lamoreau, R., Borquaye, Y., and Burke, S. (2016). A 
Summary of the Research Evidence on Inclusive Education. São Paulo: Instituto Alana Available at: https://www.abtassociates.com/sites/default/files/2019-

03/A_Summary_of_the_evidence_on_inclusive_education.pdf.

Howlin, P., Goode, S., Hutton, J., and Rutter, M. (2004). Adult outcome for children with autism. J. Child Psychol. Psychiatry 45, 212-229. Available at: http://onlinelibrary.wiley.com/doi/10.1111/j.1469-7610.2004.00215.x/abstract.

Kerikmäe, T., Chochia, A., and Atallah, M. (2018). The Baltic States in the European Union. Oxford University Press doi:10.1093/acrefore/9780190228637.013.186.

Knapp, M., Romeo, R., and Beecham, J. (2009). Economic cost of autism in the UK. Autism 13, 317-336. doi:10.1177/1362361309104246.

Lai, M.-C., Lombardo, M. V, and Baron-Cohen, S. (2014). Autism. Lancet 383, 896-910. doi:10.1016/s0140-6736(13)61539-1.

Levac, D., Colquhoun, H., and O’Brien, K. K. (2010). Scoping studies: advancing the methodology. Implement. Sci. 5, 69. doi:10.1186/1748-5908-5-69.

Loomes, R., Hull, L., and Mandy, W. P. L. (2017). What Is the Male-to-Female Ratio in Autism Spectrum Disorder? A Systematic Review and Meta-Analysis. J. Am. Acad. Child Adolesc. Psychiatry 56, 466-474. doi:10.1016/j.jaac.2017.03.013.

Mahoney, J. (2000). Path dependence in historical sociology. Theory Soc. 29, 507-548. Available at: http://webarchiv.ethz.ch/soms/teaching/OppFall09/MahoneyPathDependence.pdf.

Moher, D., Liberati, A., Tetzlaff, J., Altman, D. G., and PRISMA Group (2009). Preferred reporting items for systematic reviews and meta-analyses: the PRISMA statement. BMJ 339, b2535. doi:10.1136/BMJ.B2535.

Patenaude, B. (2012). Regional Perspectives on Human Rights: The USSR and Russia, Part One. Available at: http://spice.stanford.edu [Accessed November 21, 2019].

Peters, S., Johnstone, C., and Ferguson, P. (2005). A Disability Rights in Education Model for evaluating inclusive education. Int. J. Incl. Educ. 9, 139-160. doi:10.1080/1360311042000320464.

Republic of Estonia (1992). Constitution of the Republic of Estonia. Available at: https://www.riigiteataja.ee/akt/24304 [Accessed November 23, 2019].

Republic of Estonia (1993a). Basic Schools and Upper Secondary Schools Act. Available at: https://www.riigiteataja.ee/akt/28542 [Accessed November 23, 2019].

Republic of Estonia (1993b). Child Protection Act. Available at: https://www.riigiteataja.ee/akt/30657 [Accessed November 23, 2019]. 
Republic of Estonia (1993c). Education Act. Available at:

https://www.riigiteataja.ee/akt/30588 [Accessed November 23, 2019].

Republic of Estonia (1993d). Preschool Child Care Institution Act. Available at:

https://www.riigiteataja.ee/akt/28539 [Accessed November 23, 2019].

Republic of Estonia (1999a). Act Amending and Supplementing the Basic Schools and Upper

Secondary Schools Act. Available at: https://www.riigiteataja.ee/akt/77246 [Accessed

November 23, 2019].

Republic of Estonia (1999b). Approval of the Simplified National Curriculum for Basic

Education (Curriculum for Assistive Education). Available at:

https://www.riigiteataja.ee/akt/90764 [Accessed November 23, 2019].

Republic of Estonia (2010). Basic Schools and Upper Secondary Schools Act. Available at:

https://www.riigiteataja.ee/akt/13332410\#jg4 [Accessed November 23, 2019].

Republic of Estonia (2014). The Estonian Lifelong Learning Strategy 2020.

Republic of Estonia (2016). Organizing the Network of Basic Schools for Students with

Special Educational Needs 2014-2020. Available at:

https://www.riigiteataja.ee/akt/101032019006 [Accessed November 23, 2019].

Republic of Estonia (2018). Applying the Principles of Inclusive Education in General

Education Schools 2014-2020. Available at:

https://www.riigiteataja.ee/akt/118042018001\#para2 [Accessed November 23, 2019].

Republic of Latvia (1990). Declaration by the Supreme Council of the Socialist Republic of

Latvia Regarding the Restoration of Independence of the Republic of Latvia. Available at: https://ikumi.lv/ta/id/75539-par-latvijas-republikas-neatkaribas-atjaunosanu

[Accessed November 23, 2019].

Republic of Latvia (1991). Education Law of the Republic of Latvia. Available at:

https://likumi.lv/ta/id/67960-latvijas-republikas-izglitibas-likum [Accessed November 23, 2019].

Republic of Latvia (1993). Law of the Republic of Latvia on Medical and Social Protection of the Disabled. Available at: https://ikumi.lv/ta/id/66352-par-invalidu-medicinisko-unsocialo-aizsardzibu [Accessed November 23, 2019].

Republic of Latvia (1998a). Amendments to the Constitution of the Republic of Latvia.

Available at: https://www.vestnesis.lv/ta/id/50292-grozijumi-latvijas-republikas-

satversme [Accessed November 23, 2019].

Republic of Latvia (1998b). Children's Rights Protection Law. Available at:

https://likumi.lv/ta/id/49096-bernu-tiesibu-aizsardzibas-likums [Accessed November 23, 
2019].

Republic of Latvia (1998c). Education Law. Available at:

https://www.vestnesis.lv/ta/id/50759-izglitibas-likums [Accessed November 23, 2019].

Republic of Latvia (1999). Law of General Education. Available at:

https://likumi.lv/ta/id/20243-visparejas-izglitibas-likums [Accessed November 23, 2019].

Republic of Latvia (2010). Disability Law. Available at: https://ikumi.lv/doc.php?id=211494 [Accessed November 23, 2019].

Republic of Latvia (2012a). Arrangements for awarding and financing assistant services at educational establishments. Available at: https://likumi.lv/ta/id/252140-kartiba-kadapieskir-un-finanse-asistenta-pakalpojumu-izglitibas-iestade [Accessed November 27, 2019].

Republic of Latvia (2012b). Regulations on Pedagogical Medical Commissions. Available at: https://www.vestnesis.lv/op/2012/165.7 [Accessed November 23, 2019].

Republic of Latvia (2014). Education Development Guidelines 2014-2020. Available at: https://likumi.lv/ta/id/266406 [Accessed November 23, 2019].

Republic of Latvia (2016). Regulations Regarding Criteria and Procedures for Granting the Status of Special education development Centre to a Special Education Institution. Available at: https://likumi.lv/ta/id/281256-noteikumi-par-kriterijiem-un-kartibu-kadaspecialas-izglitibas-iestadei-pieskir-specialas-izglitibas-attistibas [Accessed December 6, 2019].

Republic of Latvia (2018). Requirements for Admission of Students with Special Needs to General Education Programs Implemented by General Education Institutions. Available at: https://likumi.lv/ta/id/301251 [Accessed December 6, 2019].

Republic of Lithuania (1991a). Law on Education of the Republic of Lithuania. Available at: https://www.e-tar.lt/portal/lt/legalAct/TAR.9A3AD08EA5D0 [Accessed November 25, 2019].

Republic of Lithuania (1991b). Law on the Social Integration of the Disabled. Available at: https://e-seimas.lrs.lt/portal/legalAct/lt/TAD/TAIS.2319?jfwid=32wfa0a4 [Accessed November 25, 2019].

Republic of Lithuania (1992). Constitution of the Republic of Lithuania. Available at: https://eseimas.1rs.lt/portal/legalAct/1t/TAD/TAIS.1890?positionInSearchResults=17\&searchMo delUUID=01 ecf603-c354-4a15-8dfa-b2de55568575 [Accessed November 25, 2019]. 
Republic of Lithuania (1998). Law on Special Education. Available at: https://eseimas.1rs.lt/portal/legalAct/lt/TAD/TAIS.69873?positionInSearchResults=3\&searchMo delUUID=f0d810cf-e202-4808-8980-b8ee642d582d [Accessed November 25, 2019].

Republic of Lithuania (2002). Order on the Procedure for the Identification of Persons with Special Needs and their Degree and the Assignment of Persons with Special Needs to the Special Education Needs. Available at: https://eseimas.lrs.lt/portal/legalAct/lt/TAD/TAIS.180989?jfwid=-hok3irklu [Accessed November 25, 2019].

Republic of Lithuania (2011a). Law amending the Law on Education of the Republic of Lithuania. Available at: https://eseimas.1rs.lt/portal/legalAct/1t/TAD/TAIS.395105?jfwid=-edboaxtlh [Accessed November 25, 2019].

Republic of Lithuania (2011b). Order on the Approval of the Description of the Procedure for the Identification of Groups of Pupils with Special Education Needs. Available at: https://e-seimas.1rs.lt/portal/legalAct/lt/TAD/TAIS.404013/asr [Accessed November 25, 2019].

Republic of Lithuania (2014). 2014-2016 Action Plan for the Strengthening of Public Education and the Development of Inclusive Education. Available at: https://eseimas.lrs.lt/portal/legalAct/lt/TAD/74fc2e20379b11e48908b52e62efa377?jfwid=edboaxq4p [Accessed November 25, 2019].

Roleska, M., Roman-Urrestarazu, A., Griffiths, S., Ruigrok, A. N. V., Holt, R., van Kessel, R., et al. (2018). Autism and the right to education in the EU: Policy mapping and scoping review of the United Kingdom, France, Poland and Spain. PLoS One 13, e0202336. doi:10.1371/journal.pone.0202336.

UNESCO (1994). The Salamanca Statement and Framework for Action on Special Needs Education. Available at: http://www.unesco.org/education/pdf/SALAMA_E.PDF [Accessed May 19, 2018].

Union of Soviet Socialist Republics (1973). Law about the Approval of Bases Legislations of the Union of the SSR and the Union Republic About Public Education. Available at: http://www.libussr.ru/doc_ussr/usr_8127.htm [Accessed November 21, 2019].

United Nations (1948). Universal Declaration of Human Rights. Available at: http://www.un.org/en/udhrbook/pdf/udhr_booklet_en_web.pdf.

United Nations (1975). Declaration on the Rights of Disabled Persons. Available at: http://www.ohchr.org/EN/ProfessionalInterest/Pages/RightsOfDisabledPersons.aspx. 
United Nations (2006). Convention on the Rights of Persons with Disabilities. Available at: http://www.ohchr.org/EN/HRBodies/CRPD/Pages/ConventionRightsPersonsWithDisabi lities.aspx\#3.

United Nations (2020). Member States. Available at: https://www.un.org/en/member-states/ [Accessed April 30, 2020].

United Nations Committee on the Rights of Persons with Disabilities (2016). Convention on the Rights of Persons with Disabilities General Comment No. 4. Available at: http://www.ohchr.org/Documents/HRBodies/CRPD/GC/RighttoEducation/CRPD-CGC-4.doc.

Van Elsuwege, P. (2008). From Soviet Republics to EU Member States. A Legal and Political Assessment of the Baltic States' Accession to the EU. Martinus Nijhoff Publishers doi:10.1163/ej.9789004169456.i-585.

van Heijst, B. F. C., and Geurts, H. M. (2015). Quality of life in autism across the lifespan: A meta-analysis. Autism 19, 158-167. Available at: http://journals.sagepub.com/doi/pdf/10.1177/1362361313517053.

van Kessel, R., Hrzic, R., Czabanowska, K., Baranger, A., Azzopardi-Muscat, N., Charambalous-Darden, N., et al. Autism and the Influence of International Legislation on Small EU Member States: Policy Mapping in Malta, Cyprus, Luxembourg, and Slovenia.

van Kessel, R., Roman-Urrestarazu, A., Ruigrok, A., Holt, R., Commers, M., Hoekstra, R. A., et al. (2019a). Autism and family involvement in the right to education in the EU: policy mapping in the Netherlands, Belgium and Germany. Mol. Autism 10. doi:10.1186/s13229-019-0297-x.

van Kessel, R., Walsh, S., Ruigrok, A. N. V., Holt, R., Yliherva, A., Kärnä, E., et al. (2019b). Autism and the right to education in the EU: policy mapping and scoping review of Nordic countries Denmark, Finland, and Sweden. Mol. Autism 10. doi:10.1186/s13229019-0290-4.

World Health Organisation (2017). Autism spectrum disorders. Available at: http://www.who.int/mediacentre/factsheets/autism-spectrum-disorders/en/ [Accessed April 25, 2018].

World Health Organisation (2019). Autism spectrum disorders. Available at: https://www.who.int/en/news-room/fact-sheets/detail/autism-spectrum-disorders [Accessed February 14, 2020]. 


\section{Supplementary Material}

\section{Supplementary File 1}

\begin{tabular}{|c|c|c|c|}
\hline & Year & Policy & Brief Description of Values \\
\hline \multirow{6}{*}{ United Nations } & 1948 & Universal Declaration of Human Rights & Lays down the right to education for every child in the United Nations, including children with SEN. \\
\hline & 1959 & Declaration on the Rights of the Child & Establishes the right for children to receive appropriate treatment that corresponds to their condition. \\
\hline & 1971 & $\begin{array}{l}\text { Declaration on the Rights of Mentally Retarded } \\
\text { Persons }\end{array}$ & $\begin{array}{l}\text { Defines the right for people with developmental, intellectual, and learning conditions to receive appropriate education to } \\
\text { maximise their potential. }\end{array}$ \\
\hline & 1975 & Declaration on the Rights of Disabled Persons & Expands the scope of the 1975 Declaration to include all children with disabilities. \\
\hline & 1989 & Convention on the Rights of the Child & Expands the role of parents in the development of a child with SEN. \\
\hline & 1994 & Salamanca Statement & $\begin{array}{l}\text { Reemphasizes the fundamental right to education for all children, as well as acknowledges that a wide diversity in special } \\
\text { education needs exist and that they should be addressed properly. }\end{array}$ \\
\hline \multirow{8}{*}{ European Union } & 1952 & European Convention on Human Rights & $\begin{array}{l}\text { A binding version of the Universal Declaration of Human Rights that applies to all European States. Adopted by the Council } \\
\text { of Europe. }\end{array}$ \\
\hline & 1992 & Charter for Persons with Autism & $\begin{array}{l}\text { Emphasises the right to accessible and appropriate education for children with autism. Adopted formally by the European } \\
\text { Parliament in } 1996 \text {. }\end{array}$ \\
\hline & 1997 & Treaty of Amsterdam & Reiterates that discrimination of any kind on the basis of disability is prohibited. \\
\hline & 2000 & $\begin{array}{l}\text { Charter of Fundamental Rights of the European } \\
\text { Union }\end{array}$ & Pools all previously stated rights and freedoms into a single document that unifies values across the EU. \\
\hline & 2009 & $\begin{array}{l}\text { Treaty on the Functioning of the European } \\
\text { Union }\end{array}$ & Delegates the competence of education completely to the EU Member States. \\
\hline & 2010 & European Disability Strategy 2010-2020 & $\begin{array}{l}\text { Aims to empower people with disabilites, acknowledges that children with SEN are often not included in mainstream } \\
\text { education, calls for inclusion. }\end{array}$ \\
\hline & 2015 & Written Declaration on Autism & Calls for an autism-specific EU strategy with the main focus to better understand autism. \\
\hline & 2018 & General Data Protection Regulation & $\begin{array}{l}\text { Consent is required to access health data, which can complicate the communication between the many parties involved in } \\
\text { addressing health and SEN of a child with autism. }\end{array}$ \\
\hline
\end{tabular}

\section{Supplementary File 2}

\begin{tabular}{|c|c|c|c|}
\hline Country & Year & Policy & Description \\
\hline \multirow[t]{4}{*}{$\begin{array}{l}\text { Union of Soviet } \\
\text { Socialist Republics }\end{array}$} & 1936 & $\begin{array}{l}\text { Constitution of the Union of } \\
\text { Soviet Socialist Republics }\end{array}$ & $\begin{array}{l}\text { Defined the USSR as a federal state, formed of the association of Soviet Socialist Republics having equal } \\
\text { rights } \\
\text { The communist ideology accentuated economic and social rights, such as access to healthcare and education } \\
\text { Stipulated the right to education for all citizens of the Soviet Union, which included universal, compulsory, } \\
\text { and free public education }\end{array}$ \\
\hline & 1940 & Revision to the Constitution & $\begin{array}{l}\text { Added the Lithuanian SSR, the Latvian SSR, and the Esthonian SSR to the list of Soviet Socialist Republics } \\
\text { appointed } \\
\text { Jurisdiction of the USSR included the establishment of the basic principles in the field of education and } \\
\text { public health, which limited the Union Republics' sovereignty within this provision and reformed the Baltic } \\
\text { educational systems }\end{array}$ \\
\hline & 1973 & $\begin{array}{l}\text { Law about the Approval of } \\
\text { Bases Legislations of the } \\
\text { Union of the SSR and the } \\
\text { Union Republic About Public } \\
\text { Education }\end{array}$ & $\begin{array}{l}\text { Laid down the general principles of the law and placed the purpose of public education in the USSR in the } \\
\text { context of systematic improvement of socialism and in favour of further advancement of Soviet society by } \\
\text { preparing highly educated and harmoniously developed citizens as convinced fighters for communism, with } \\
\text { a strong attitude toward work and active participation in state life } \\
\text { Special schools, boarding schools, and orphanages were to be organised for children and adolescents with } \\
\text { disabilities in physical or mental development that impede learning in a general school environment and } \\
\text { requires special education } \\
\text { This was done in order to provide education, training, and treatment for these children and adolescents and } \\
\text { prepare them for socially useful work } \\
\text { Ratified a clear division into a separate general and special education system and was guided by the ideology } \\
\text { that all citizens must eventually contribute to the communist society }\end{array}$ \\
\hline & 1975 & $\begin{array}{l}\text { Lithuanian SSR Law on Public } \\
\text { Education }\end{array}$ & $\begin{array}{l}\text { Special preschool facilities were set up for special education and training of children with physical or mental } \\
\text { disabilities } \\
\text { Children were admitted to special preschools at the request of their parents or their deputies, per the } \\
\text { conclusions of a pedagogical medical commission } \\
\text { Enforced that special education schools and boarding schools were founded for children and adolescents with } \\
\text { physical or mental disabilities that hinder them from learning in mainstream schools, as well as those with } \\
\text { special educational needs, in order to ensure their education }\end{array}$ \\
\hline \multirow[t]{3}{*}{ Estonia } & 1992 & Estonian Constitution & $\begin{array}{l}\text { Established the right to education for everyone } \\
\text { Declared education to be under State supervision and compulsory for school-age children to the extent } \\
\text { prescribed by law } \\
\text { Education received at State and local government general education schools shall be free of charge and } \\
\text { parents have a decisive voice in the choice of their children's education } \\
\text { People and families with children with disabilities are under special care of the State and local governments }\end{array}$ \\
\hline & 1993 & Child Protection Act & $\begin{array}{l}\text { Affirmed the right of every child to an innate right to life, health, development, work, and well-being } \\
\text { A child with disability shall have the same opportunities as any other child for education and self- } \\
\text { development } \\
\text { This law was repealed when the new Child Protection Act was established in 2014, though the amended } \\
\text { version did not reiterate the right to education }\end{array}$ \\
\hline & 1993 & Education Act & $\begin{array}{l}\text { The State and local governments shall ensure everyone's opportunities to obtain schooling and continuous } \\
\text { education } \\
\text { The local government shall ensure the opportunity for individuals with physical, mental, speech, and } \\
\text { intellectual disabilities and persons in need of special assistance to study in a school of their place of } \\
\text { residence } \\
\text { In the absence of suitable conditions for educating pupils with SEN in the area, the State or local authorities } \\
\text { shall provide them with nearby study opportunities in a class or institution established for this purpose }\end{array}$ \\
\hline
\end{tabular}




\begin{tabular}{|c|c|}
\hline 1993 & $\begin{array}{l}\text { Pre-school Child Care } \\
\text { Institutions Act }\end{array}$ \\
\hline 1993 & $\begin{array}{l}\text { Basic Schools and Upper } \\
\text { Secondary Schools Act }\end{array}$ \\
\hline 1999 & $\begin{array}{l}\text { Act Amending and } \\
\text { Supplementing the Basic } \\
\text { Schools and Upper Secondary } \\
\text { Schools Act }\end{array}$ \\
\hline
\end{tabular}

The local government shall ensure the opportunity for individuals with physical, mental, speech, and intellectual disabilities and persons in need of special assistance to study in a school of their place of residence

In the absence of suitable conditions for educating pupils with SEN in the area, the State or local authorities The first jurisdictional act to elaborate on the organisation behind the inclusion of pupils with SEN The abovementioned responsibilities of the local government were expanded and ratified that Advisory Committees are responsible for assessing and establishing education for all children with SEN

An Advisory Committees shall be formed by the County Governor and consists of a special educator, a speech therapist, a psychologist, a social worker, and a representative of the county or city government The following are within the competence of an advisory committee:

(1) determine the curriculum or form of study appropriate to the needs of the child

(2) direct the child to a sanatorium school or a school or class for children with SEN with the consent of the

legal guardian; and

(3) decide on postponement of compulsory school attendance at the request of the parent

A Simplified National Curriculum for Basic Education (Curriculum for Assistive Education) shall be established by a regulation of the Minister of Education

1999 Approval of the Simplified National Curriculum for Basic Education (Curriculum for Assistive Education)
The curriculum forms the framework whereupon each assistant school or assistant class draws its own curriculum

Provides the basis for individualised curricula for students who need a curriculum in auxiliary curricula a other types of schools or who have partially different goals and requirements at the assisting school The Curriculum is based on the national basic curriculum with differences due to the peculiarities of the development of pupils with SEN

The main differences are the simplified syllabi and the greater focus on the development of basic skills and self-reliance in life

Stated that the Simplified Curriculum for Basic Education is based on the principles of humanism, democracy, and equal access to education

Everyone must have the opportunity to receive education according to their abilities, which is realised through the integration of students in need of assistance in the Estonian school system

These students have the right to study in auxiliary schools, auxiliary classes, or an individual curriculum in mainstream schools or other types of schools for children with disabilities

In individual cases, home schooling for children in need of assistance is provided in accordance with legislation

The organisation of education and the choice of content will take the students' abilities and other individual characteristics into account

2004 The Act amending the Preschool Child Care Institution Act, the Social Welfare Act, the Basic Schools and Upper Secondary Schools Act, the Republic of Estonia Child Protection Act, the Superannuated Pensions Act and the Education Act

eviation "was the common term to refer to people with disabilities

The term "deviant person" was replaced with "persons with special needs" in all legislation concerning disabled people 


\begin{tabular}{|c|c|c|}
\hline 1991 & $\begin{array}{l}\text { Education Law of the Republic } \\
\text { of Latvia }\end{array}$ & $\begin{array}{l}\text { Children with mental or physical disabilities shall be placed in sanatorium-type schools and discharged only } \\
\text { on the basis of the opinion of a medical-pedagogical commission } \\
\text { These children were partially or fully dependent on the State. Therefore, they would receive free treatment, } \\
\text { meals, and medical and technical aids }\end{array}$ \\
\hline 1993 & $\begin{array}{l}\text { Law on Medical and Social } \\
\text { Protection of the Disabled }\end{array}$ & $\begin{array}{l}\text { De jure rights of persons with disabilities were established in national legislation } \\
\text { Stated the responsibilities of the State and municipalities regarding the protection of people with disabilities } \\
\text { In order to promote the social inclusion of people with disabilities, the law regulated that municipalities } \\
\text { shall ensure that persons with disabilities are provided with access to appropriate education at home, in } \\
\text { specialised or general educational institutions, with equipment and technical aids adapted to their needs } \\
\text { Was repealed and replaced with the Disability Law in } 2010\end{array}$ \\
\hline 1994 & $\begin{array}{l}\text { Law on International } \\
\text { Agreements of the Republic of } \\
\text { Latvia }\end{array}$ & $\begin{array}{l}\text { Determined the execution and ratification related to international treaties } \\
\text { When an international treaty is binding and Latvian laws contain other provisions, the international } \\
\text { agreement shall apply, thereby giving pre-eminence of international law over national legislation }\end{array}$ \\
\hline 1998 & $\begin{array}{l}\text { Amendments to the } \\
\text { Constitution of the Republic } \\
\text { of Latvia }\end{array}$ & $\begin{array}{l}\text { Added a chapter on Fundamental Human Rights } \\
\text { Ensured that all people in Latvia are equal by law and before the courts and human rights are effectuated } \\
\text { without discrimination of any sort } \\
\text { Entitled everyone the right to education by making basic education compulsory and assuring free access to } \\
\text { primary and secondary education }\end{array}$ \\
\hline 1998 & $\begin{array}{l}\text { Children's Rights Protection } \\
\text { Law }\end{array}$ & $\begin{array}{l}\text { Addressed the rights of children } \\
\text { Affirmed the State's obligation to ensure equal rights to education for all children } \\
\text { Contained a full chapter on children with SEN, which ratified that children with special needs have the same } \\
\text { rights as other children to an active life, to develop, to take part in social life, and to acquire education } \\
\text { matching their physical and mental abilities and aspirations } \\
\text { Guarantees that pedagogical and social workers are specially trained to work with children with SEN } \\
\text { For this purpose special training programmes would be }\end{array}$ \\
\hline 1998 & Law on Education & $\begin{array}{l}\text { Replaced the } 1991 \text { Education Law } \\
\text { Set the new legal framework for the main principles and procedures of the (special) education environment } \\
\text { Defined special education as general and vocational education adapted for people with special needs or health } \\
\text { problems } \\
\text { Determined that persons with special needs might acquire special education at a mainstream educational } \\
\text { institution if it is ensured that the student could acquire education corresponding to their abilities } \\
\text { Stated that the implementation of special education programmes shall be determined by the Law on General } \\
\text { Education and other legislative documents }\end{array}$ \\
\hline 1999 & Law on General Education & $\begin{array}{l}\text { Set out the definitions, principles, and organisation of special education } \\
\text { Stated that special education can be provided for children with acquired or hereditary functional disorders } \\
\text { according to their SEN } \\
\text { Children with SEN may acquire special educational programmes in special educational institutions or clas ses } \\
\text { too, which can be state-owned, municipal or private } \\
\text { Emphasised that general primary and secondary schools can integrate children with SEN when they are able to } \\
\text { provide them with adequate facilities } \\
\text { Defined special education programmes, describing that educational programmes for children with intellectual } \\
\text { disabilities are offered for nine years and may be implemented over a longer period, but not exceeding twelve } \\
\text { years } \\
\text { Mandated the assessment of students' disabilities for educational purposes, and the selection of an } \\
\text { appropriate special education program, to the State and Municipal Medical Pedagogical Commissions }\end{array}$ \\
\hline 2010 & Disability Law & $\begin{array}{l}\text { Provided the rights for students in pre-school education, basic education, basic vocational education, and } \\
\text { vocational secondary education as well as higher education and college students with disabilities } \\
\text { Assistant services are paid by the state budget to support mobility and self-care }\end{array}$ \\
\hline 2012 & $\begin{array}{l}\text { Arrangements for awarding and } \\
\text { financing assistant services at } \\
\text { educational establishments }\end{array}$ & $\begin{array}{l}\text { Assistant services include support for the student with SEN in carrying out activities which he or she is } \\
\text { unable to carry out independently, such as moving to an educational establishment and self-care } \\
\text { Describes that the person who assists a student with SEN has to be someone who has work or personal } \\
\text { experience in caring for persons with disabilities, or who has appropriate education or work experience in the } \\
\text { field of pedagogy, psychology, medicine, health or social work }\end{array}$ \\
\hline 2012 & $\begin{array}{l}\text { Regulations on Pedagogical } \\
\text { Medical Commissions }\end{array}$ & $\begin{array}{l}\text { Prescribed the competence of Medical Pedagogical Commissions and the procedure for their establishment } \\
\text { Described the commissions' main responsibilities: } \\
\text { (1) assess the learner's state of health, abilities and development level and give an opinion on the most } \\
\text { appropriate educational program for the learner } \\
\text { (2) promote integration of students with special needs into general education institutions } \\
\text { (3) consult teachers and parents on special education issues; and } \\
\text { (4) provide methodological support, analyse, and coordinate the work of special education teachers } \\
\text { The criteria for the Pedagogical Medical Commissions' opinions were added and childhood autism, atypical } \\
\text { autism, and Asperger's syndrome are all mentioned as a possible basic diagnosis for pupils with SEN } \\
\text { It is the competence of the State Commission to provide an opinion on the most appropriate special primary } \\
\text { or secondary education program for students with special needs in grades 1-12 } \\
\text { The competence of municipal commissions is to provide an opinion on the most appropriate pre-school or } \\
\text { special pre-school curriculum, special primary education curriculum for pupils with intellectual disabilities, } \\
\text { severe mental or multiple disabilities, learning disabilities, language disorders or mental health problems in } \\
\text { grades 1-4 }\end{array}$ \\
\hline 2014 & $\begin{array}{l}\text { Education Development } \\
\text { Guidelines 2014-2020 }\end{array}$ & $\begin{array}{l}\text { Linked the European Union's development priorities with the national objectives } \\
\text { Emphasised the importance of inclusive education and personalised learning approaches } \\
\text { The concept of inclusive education is defined as a process that responds to the diverse needs of all learners by } \\
\text { increasing the participation of all learners in the learning process, culture, and communities and reducing } \\
\text { exclusion from education and training } \\
\text { Children and young people at risk of exclusion and ill health and social conditions are identified as the } \\
\text { target group in the provision of inclusive education } \\
\text { Described that there is a need for education systems to respond to diversity and to ensure the successful } \\
\text { inclusion of all in the education system, children and young people with special needs are not sufficiently } \\
\text { supported in the education process }\end{array}$ \\
\hline 2016 & $\begin{array}{l}\text { Regulations Regarding } \\
\text { Criteria and Procedures for } \\
\text { Granting the Status of Special } \\
\text { education development Centre } \\
\text { to a Special Education } \\
\text { Institution }\end{array}$ & $\begin{array}{l}\text { Establishes Special Education Development Centres } \\
\text { Their areas of activities are: } \\
\text { (1) To provide early diagnosis of special needs for preschool children, regadless of the place of education } \\
\text { (2) To provide methodical and pedagogical assistance to educators of educational institutions, in the the } \\
\text { development of an individual educational programme acquisition plan and an assessment of the dynamics of } \\
\text { achievements } \\
\text { (3) To develop training or methodological supporting materials to encourage the integration of learners with } \\
\text { special needs into the educational process } \\
\text { (4) To organise informative educational events, including teacher training activities etc. }\end{array}$ \\
\hline
\end{tabular}


$2018 \quad$ Requirements for Admission of Students with Special Needs to General Education Programs to General Education Prog Education Institutions

\begin{tabular}{lll}
\hline Lithuania 1991 & $\begin{array}{l}\text { Law on Education of the } \\
\text { Republic of Lithuania }\end{array}$
\end{tabular}

\begin{tabular}{ll}
\hline 1991 & $\begin{array}{l}\text { Law on Social Integration of } \\
\text { the Disabled }\end{array}$ \\
\hline 1992 & $\begin{array}{l}\text { Consitution of the Republic of } \\
\text { Lithuania }\end{array}$ \\
\hline 1998 & Law on Special Education
\end{tabular}

2002 Order on the Procedure for the Identification of Persons with Special Needs and their Degree and the Assignment of Persons with Special Needs to the Special Education Needs

2011 Law amending the Law on Education of the Republic of Lithuania
These rules rewrite what school requirements are in place to ensure inclusive education for children with

different health problems

They also include learning and mental health conditions (without diagnosis specifications)

The rules require the school to provide

(1) rehabilitation lessons

2) additional individual or group training sessions if necessary

(3) counseling of a psychologist

(4) a safe regime in the training and parenting process

For pupils with behaviour disabilities, an individual behavioural adjustment plan need to be developed

Marked the reform of the Soviet education system to the national education system

Consolidated the democratic and humanistic principles of the Lithuanian education system and established the general framework of its organisation and activities

Pre-school and school-aged children with physical or mental disabilities could be educated in general or correctional classes within mainstream settings

Recognised integration of the disabled as one of the indicators of civilisation and affirmed their right to education

Assured the fortitude of the Lithuanian State to seek an open and harmonious democratic society

Stated that education is compulsory for every citizen under the age of 17

Elaborated on the structure of the special education system and set the basis for the organisation and

management of special education in early and pre-school, general, vocational, and higher educational institutions

Marked the Republic's responsibility for providing appropriate and free education for all youngsters (until the age of 21) with SEN in the most integrated environment

Defined persons with special needs as children and adults with limited abilities to participate in the educational process and society due to congenital or acquired disorders

Listed the principles of special education, i.e. equal opportunities, integration, decentralisation, universality, continuity, and educational functionality

continuity, and educational functionality
Regulated the provision of assistive technical aids and training appliances

Ensured children with SEN free transportation to educational establishments if necessary

Special educational needs of a person were evaluated by the special education commission of the school

Stated that special educational needs are identified on the basis of the "Disability Identification and

Curriculum Memorandum"

In the attached Memorandum, childhood autism and atypical autism fall under the group of Emotional, Behavioural, and Social Developmental Disorders

The suggested curriculum implied adapting the general curriculum for one, several, or all subjects, further defined as a general education program that does not meet the standards of state education and is adapted to the needs of a person with SEN at a realistic level of education

Repealed the 1998 Law on Special Education

Formed the new legal basis for the accessibility and organisation of education for students with SEN The purpose was to assist pupils in their education, skills, and qualifications by recognising and developing their competences, which was to be implemented by all schools providing compulsory and public education, other education providers, and by schools or classes intended for educating pupils with SEN

Ensured access to special education by adapting the school environment, by supplying schools with

technological aids, and by providing special psychological, pedagogical, and social-pedagogical assistance
2011 Order on the Approval of the Description of the Procedure for the Identification of Groups of Pupils with Specia Education Needs
Described the identification of disorders, disabilities, and learning difficulties that create special educational needs and the criteria for grading their special educational needs

Childhood autism, atypical autism, and Asperger's syndrome were classified under Various Developmental Childhood
Disorder

The current consolidated version of the Procedure respectively defined

(1) childhood autism as "characteristic developmental disorders, which occur in children under three years of age and occur in three areas: social, communication, and behaviour;"

(2) atypical autism as "characteristic developmental disorders, occurring at the age of three years and occurring in one or two of the three groups of symptoms necessary for the diagnosis of autism;" and (3) Asperger's syndrome as "social communication disorders similar to autism, with a limited stereotypical, repetitive set of activities and interests. The condition differs from autism in that there is no general retardation or difficulty in language or cognitive development."

2012 Resolution on the Approval of The strategic goal of the Program was to develop a favourable environment and the conditions for dignified the National Program for Social Integration of Person with Disabilities for 20132019 lives of persons with disabilities as well as to ensure equal treatment and quality of life for all disabled people in Lithuania

Described the objective to ensure the provision of the special needs of people with disabilities through social integration services (i.e. social security, health care, education)

The objective was based on the analyses that the environment of educational establishments was not sufficiently adapted for the disabled and methodological assistance to educational institutions and parents was not found to be adequate

2013 Resolution on the Approval of $\quad$ Described policy priorities, long-term goals, and changes of direction in content and funding of the the National Education Lithuanian education system

Strategy 2013-2022 Aimed to transform Lithuania's education into a sustainable basis for pupils to ensure that they fulfil their true potential

The third objective of the Strategy was to provide the most favourable opportunities for pupils and students to develop their individual skills and meet their special educational needs by ensuring access to education and equal opportunities, while maximising the scope of education for children and adolescents

\section{2014-2016 Action Plan for the Sought to develop and enhance the quality of inclusive education for children with SEN by increasing the Strengthening of Public provision of special educational assistance}

Education and the

Development of Inclusive Education

$2016 \quad 2017-2022$ Action Plan on

Child Inclusion and Diverse Education

$2019 \quad 2019-2020$ Action Plan for Strengthening Assistance for Children with Autism or Othe Children with Autism or O
Developmental Disorders 


\section{Supplementary File 3}

\section{The Baltic Soviet Socialist Republic}

Supreme Council of the Republic of Lithuania. Lithuanian SSR Law on Public Education (1975). Retrieved from https://eseimas.1rs.lt/portal/legalAct/lt/TAD/329f75b01e7b11e585eaba374ef4b409?jfwid=32wf9 qdt

Union of Soviet Socialist Republics. The Constitution of the USSR as amended on December 5, 1936 (1936). Retrieved from http://constitution.garant.ru/history/ussrrsfsr/1936/red_1936/3958676/

Union of Soviet Socialist Republics. The Constitution of the USSR as amended on August 7, 1940 (1940). Retrieved from http://constitution.garant.ru/history/ussrrsfsr/1936/red_1936/3958681/

Union of Soviet Socialist Republics. Law about the Approval of Bases Legislations of the Union of the SSR and the Union Republic About Public Education (1973). Retrieved from http://www.libussr.ru/doc_ussr/usr_8127.htm

United Nations. (2019). Member States. Retrieved from https://www.un.org/en/memberstates/

\section{Estonia}

Republic of Estonia. Constitution of the Republic of Estonia (1992). Retrieved from https://www.riigiteataja.ee/akt/24304

Republic of Estonia. Basic Schools and Upper Secondary Schools Act (1993). Retrieved from https://www.riigiteataja.ee/akt/28542

Republic of Estonia. Child Protection Act (1993). Retrieved from https://www.riigiteataja.ee/akt/30657

Republic of Estonia. Education Act (1993). Retrieved from https://www.riigiteataja.ee/akt/30588

Republic of Estonia. Preschool Child Care Institution Act (1993). Retrieved from https://www.riigiteataja.ee/akt/28539

Republic of Estonia. Act Amending and Supplementing the Basic Schools and Upper Secondary Schools Act (1999). Retrieved from https://www.riigiteataja.ee/akt/77246 Republic of Estonia. Approval of the Simplified National Curriculum for Basic Education (Curriculum for Assistive Education) (1999). Retrieved from https://www.riigiteataja.ee/akt/90764 
Republic of Estonia. The Act amending the Pre-school Child Care Institutions Act, the Social Welfare Act, the Basic Schools and Upper Secondary Schools Act, the Republic of Estonia Child Protection Act, the Superannuated Pensions Act and the Education Act (2004). Retrieved from https://www.riigiteataja.ee/akt/738632

Republic of Estonia. Basic Schools and Upper Secondary Schools Act (2010). Retrieved from https://www.riigiteataja.ee/akt/13332410\#jg4

Republic of Estonia. Simplified National Curriculum for Basic School (2010). Retrieved from https://www.riigiteataja.ee/akt/128122010014?leiaKehtiv

Republic of Estonia. (2014). The Estonian Lifelong Learning Strategy 2020.

Republic of Estonia. Organizing the Network of Basic Schools for Students with Special Educational Needs 2014-2020 (2016). Retrieved from https://www.riigiteataja.ee/akt/101032019006

Republic of Estonia. Applying the Principles of Inclusive Education in General Education Schools 2014-2020 (2018). Retrieved from https://www.riigiteataja.ee/akt/118042018001\#para2

\section{Latvia}

Republic of Latvia. Constitution of the Republic of Latvia (1922). Retrieved from https://ikumi.lv/ta/id/57980-latvijas-republikas-satversme Republic of Latvia. Declaration by the Supreme Council of the Socialist Republic of Latvia Regarding the Restoration of Independence of the Republic of Latvia (1990). Retrieved from https://likumi.lv/ta/id/75539-par-latvijas-republikas-neatkaribas-atjaunosanu Republic of Latvia. Education Law of the Republic of Latvia (1991). Retrieved from https://likumi.lv/ta/id/67960-latvijas-republikas-izglitibas-likum

Republic of Latvia. (1993). Law of the Republic of Latvia on Medical and Social Protection of the Disabled. Retrieved November 23, 2019, from https://likumi.lv/ta/id/66352-parinvalidu-medicinisko-un-socialo-aizsardzibu

Republic of Latvia. Law on International Agreements of the Republic of Latvia (1994). Retrieved from https://www.vestnesis.lv/ta/id/57840-par-latvijas-republikasstarptautiskajiem-ligumiem

Republic of Latvia. (1998a). Amendments to the Constitution of the Republic of Latvia. Retrieved November 23, 2019, from https://www.vestnesis.lv/ta/id/50292-grozijumilatvijas-republikas-satversme

Republic of Latvia. (1998b). Children's Rights Protection Law. Retrieved November 23, 2019, from https://likumi.lv/ta/id/49096-bernu-tiesibu-aizsardzibas-likums 
Republic of Latvia. (1998c). Education Law. Retrieved November 23, 2019, from https://www.vestnesis.lv/ta/id/50759-izglitibas-likums

Republic of Latvia. Law of General Education (1999). Retrieved from https://likumi.lv/ta/id/20243-visparejas-izglitibas-likums

Republic of Latvia. (2010). Disability Law. Retrieved November 23, 2019, from https://likumi.lv/doc.php?id=211494

Republic of Latvia. Arrangements for awarding and financing assistant services at educational establishments (2012). Retrieved from https://likumi.lv/ta/id/252140kartiba-kada-pieskir-un-finanse-asistenta-pakalpojumu-izglitibas-iestade

Republic of Latvia. (2012b). Regulations on Pedagogical Medical Commissions. Retrieved November 23, 2019, from https://www.vestnesis.lv/op/2012/165.7

Republic of Latvia. (2014). Education Development Guidelines 2014-2020. Retrieved November 23, 2019, from https://likumi.lv/ta/id/266406

Republic of Latvia. Regulations Regarding Criteria and Procedures for Granting the Status of Special education development Centre to a Special Education Institution (2016). Retrieved from https://likumi.lv/ta/id/281256-noteikumi-par-kriterijiem-un-kartibukada-specialas-izglitibas-iestadei-pieskir-specialas-izglitibas-attistibas

Republic of Latvia. Requirements for Admission of Students with Special Needs to General Education Programs Implemented by General Education Institutions (2018). Retrieved from https://likumi.lv/ta/id/301251

\section{Lithuania}

Republic of Lithuania. (1991a). Law on Education of the Republic of Lithuania. Retrieved November 25, 2019, from https://www.e-tar.lt/portal/lt/legalAct/TAR.9A3AD08EA5D0 Republic of Lithuania. Law on the Social Integration of the Disabled (1991). Retrieved from https://e-seimas.lrs.lt/portal/legalAct/lt/TAD/TAIS.2319?jfwid=32wfa0a4

Republic of Lithuania. Constitution of the Republic of Lithuania (1992). Retrieved from https://eseimas.1rs.lt/portal/legalAct/lt/TAD/TAIS.1890?positionInSearchResults=17\&searchMo delUUID=01 ecf603-c354-4a15-8dfa-b2de55568575

Republic of Lithuania. Law on Special Education (1998). Retrieved from https://eseimas.1rs.lt/portal/legalAct/lt/TAD/TAIS.69873?positionInSearchResults=3\&searchMo delUUID=f0d810cf-e202-4808-8980-b8ee642d582d

Republic of Lithuania. Order on the Procedure for the Identification of Persons with Special 
Needs and their Degree and the Assignment of Persons with Special Needs to the Special Education Needs (2002). Retrieved from https://eseimas.lrs.lt/portal/legalAct/lt/TAD/TAIS.180989?jfwid=-hok3irklu

Republic of Lithuania. (2011a). Law amending the Law on Education of the Republic of Lithuania. Retrieved November 25, 2019, from https://eseimas.lrs.lt/portal/legalAct/lt/TAD/TAIS.395105?jfwid=-edboaxtlh

Republic of Lithuania. (2011b). Order on the Approval of the Description of the Procedure for the Identification of Groups of Pupils with Special Education Needs. Retrieved November 25, 2019, from https://eseimas.lrs.lt/portal/legalAct/lt/TAD/TAIS.404013/asr

Republic of Lithuania. (2012). Resolution on the Approval of the National Program for Social Integration of Persons with Disabilities for 2013-2019. Retrieved November 25, 2019, from https://e-

seimas.1rs.lt/portal/legalAct/en/TAD/98ca3ed4271011e6a222b0cd86c2adfc

Republic of Lithuania. (2013). Resolution on the Approval of the National Education Strategy 2013-2022. Retrieved November 25, 2019, from https://eseimas.1rs.lt/portal/legalAct/lt/TAD/TAIS.463390?jfwid=32wf9yee

Republic of Lithuania. 2014-2016 Action Plan for the Strengthening of Public Education and the Development of Inclusive Education (2014). Retrieved from https://eseimas.lrs.1t/portal/legalAct/lt/TAD/74fc2e20379b11e48908b52e62efa377?jfwid=edboaxq4p

Republic of Lithuania. 2017-2022 Action Plan on Child Inclusion and Diverse Education (2017). Retrieved from https://eseimas.1rs.lt/portal/legalAct/1t/TAD/aad10e305c3c11e 7a53b83ca0142260e?jfwid=5w7a v14go

Republic of Lithuania. (2019). 2019-2020 Action Plan for Strengthening Assistance for Children with Autism or Other Developmental Disorders. Retrieved November 26, 2019, from https://eseimas.lrs.lt/portal/legalAct/lt/TAD/cb6658326a5411e99684a7f33a9827ac?positionIn SearchResults=1\&searchModelUUID=f0d810cf-e202-4808-8980-b8ee642d582d 


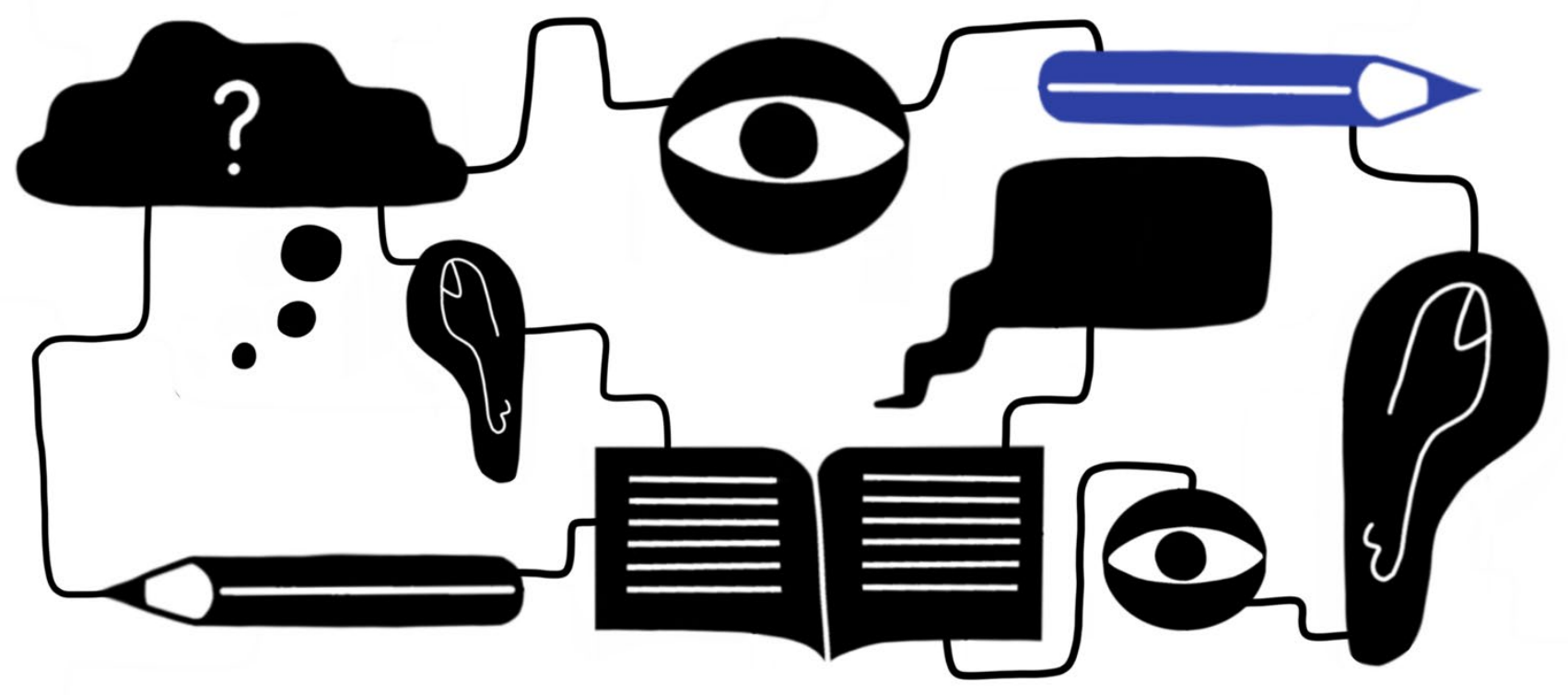

\section{Chapter Six}

Qualitative Comparative Analysis

\section{Published as:}

van Kessel, R., Hrzic, R., Cassidy, S., Brayne, C., Baron-Cohen, S., Roman-Urrestarazu, A., \& Czabanowska, K. Inclusive Education in the European Union: A Fuzzy-Set Qualitative Comparative Analysis of Education Policy for Autism. Preprint at https://www.researchsquare.com/article/rs-36514/v1 [Accepted in Social Work in Public Health; IF(2019): 0,607] 


\section{Abstract}

Background: Children with special education needs (SEN), such as children with autism, benefit from being included in education along with typical peers. However, development and implementation of inclusive education (IE) is considered difficult. This paper identifies conditions that facilitate IE development for children with autism in the European Union and benchmarks to track IE policy development.

Methods: Education policy data from thirty legislative regions in the European Union were analyzed through a qualitative comparative analysis using eight conditions: a definition of SEN, the right to education for children with SEN, support for teaching staff, support services for children with SEN, individualized learning outcomes, parental involvement, and mixed mainstream classes.

Results: The right to education for children with SEN is implemented in all regions under study. Seven of the examined conditions were associated with an environment of IE in the European Union from an autism perspective: an established definition of SEN, support for teaching staff, general availability of support services for children with SEN, individualized learning outcomes, parental involvement, IE policies, and mixed mainstream classrooms. Mixed classrooms and support services for children with SEN were identified as necessary for IE. IE policies and support for teaching staff were present in all scenarios that facilitated IE. Even though the analysis was initially focused on autism, the policies consisted predominantly of general SEN policies. As such, the results can be interpreted in a wider context, beyond autism.

Conclusion: Mixed mainstream classrooms and support services for children with special needs were found essential for consistent IE development. Support for teaching staff and IE policies facilitate IE and should be further explored and implemented.

Keywords: education, inclusion, special education needs, European Union, policy, autism

\section{Background}

The prevalence of special education needs (SEN) in children in the European Union (EU) varies between 1-20\% depending on the classification system [1]. The Council of Europe has associated segregation of children with SEN with lapsed learning opportunities that are worsened by isolation and lack of inclusion in mainstream education [2]. Moving from segregation-based education systems to inclusive education (IE) systems is therefore an important goal for the autism community in the EU. However, the United Nations (UN) also 
acknowledged that there are children that simply cannot participate in mainstream classes, regardless of the support services. Attending mainstream education with SEN support would still not meet the child's educational or social needs or would inhibit the child's welfare in any other way [3]. For these children, segregated facilities are retained in order to ensure access to education.

IE has widely emerged with the goal of enhancing education for children with SEN by adjusting classroom practices to individual needs [4]. Including children with SEN in mainstream classrooms is found to benefit their academic and social skills, and their wellbeing [4-6]. That being said, implementing IE is considered difficult since education systems typically develop in very specific contexts, both in policy and practice, thus making each unique in how it functions [7]. Systems of IE are also typically embedded in a combination of mainstream and special education frameworks [7]. Therefore, frameworks are created to help guide and streamline the implementation, such as the Disability Rights in Education Model (DREM) [8]. The DREM is a guidance tool that provides a multilevel framework for evaluating aspects of IE at local, national, and international levels and outlines vital points to focus on to further the development of IE [8]. It also stresses that the different points in the framework have to interact for IE to be achieved, both in-level (e.g. different factors at the national level) and cross-level (e.g. national and international). However, recent reviews suggest that providing guidance on specific SEN may be more feasible than the generalized guidance that the DREM offers [4].

One in 160 children, approximately $1 \%$ of people worldwide, are on the autism spectrum and many have significant health and education needs $[9,10]$. Recently, autism, SEN, and education policies in 20 EU Member States - covering 76,87\% of the EU population [11] have been mapped by the European Consortium for Autism Researchers in Education (EDUCAUS) using a path dependency framework. The aim of EDUCAUS was to systematically compare policy across all EU Member States against the vision of an education system which supports children with autism to fulfil their potential [12-17] [in press]. Each policy analysis focused on a specific theme, including parental involvement [13], teacher education [14,16], and teacher responsibilities [16]. Each review found IE to be present in national policies of most Member States, though many of the investigated countries also retain segregation-based frameworks. It therefore remains unclear what factors 
are truly influential and effective in developing inclusive education for children with autism on a policy level.

This work aims to synthesize the policy data of EDUCAUS and contribute to modelling pathways that are associated with the development of IE in EU Member States from the perspective of children with autism and identifying benchmarks that can be used to track the development of IE on a policy level. Subsequently, key drivers that can aid the development of a policy of inclusion for children with autism in EU Member States in different contexts can be pinpointed as well. This is necessary to direct future policy and research endeavors for education policy pertaining to inclusive education for children with autism. One challenge of comparative studies on inclusion is to capture the complexity of the terminology, show different possible pathways and interpretations, and discuss their respective consequences for practice [7].

A Qualitative Comparative Analysis (QCA) is a suitable option to map these possible pathways and interpret their meanings in light of existing literature for several reasons. Firstly, IE is defined as an outcome that is contingent on the combinations of different factors $[4,5,18]$, which is a requirement for the usage of QCA [19]. Secondly, QCA formalizes and systematizes case comparison. This addresses the common concern of scientificity (i.e. based on principles of science) surrounding case studies that the case study material is compared in a loose and unformalized way [20]. QCA refers to a case-based methodology in which (1) conditions and outcomes are previously identified, (2) an examination on which of these conditions are considered necessary and/or sufficient for an outcome to occur is performed, and (3) a systematic comparison is made to determine which combinations of conditions are associated with an outcome [21-23].

\section{Methods}

\section{Theoretical Background}

QCA is a mixed-method approach developed by Ragin [23] and has been used to analyze comparative case studies that include a medium number of cases (usually between 10 and 50) [19]. It uses set theory and Boolean minimization to identify patterns in the data [22,23]. QCA thus takes an alternative approach to causal analysis compared to probabilistic methods (such as regression models) [24]. QCA instead considers what variables (henceforth conditions), individually or in combination, are required to produce an outcome [24,25]. Its 
approach to causation recognizes that the conditions that produce an outcome do not work isolated but complementary and acknowledges the possibility of more than one combination of conditions to produce an outcome [26] For a visual representation of the QCA method, see Fig1.

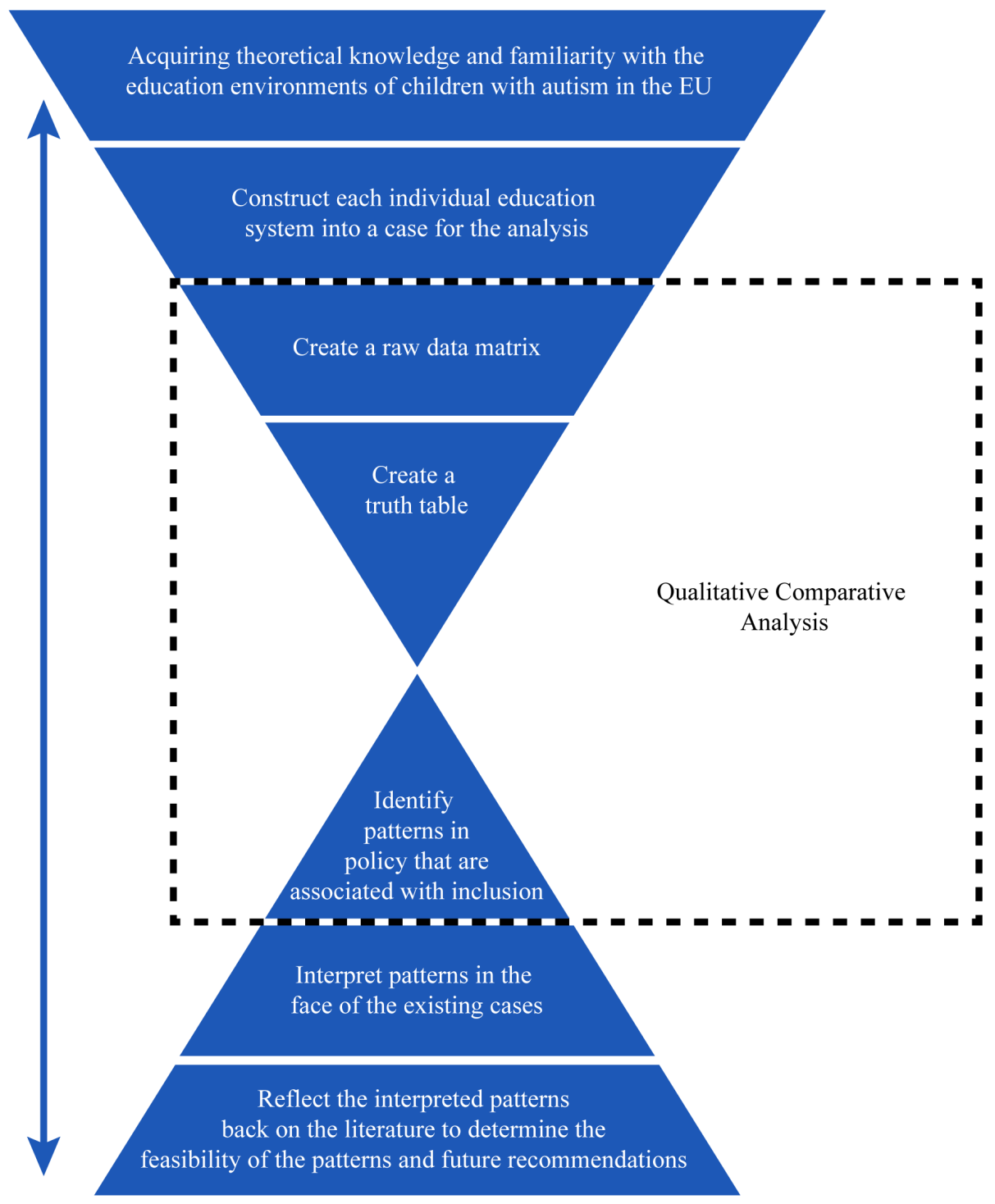

Fig1. A representation of what a Qualitative Comparative Analysis. Source: Adaptation of the illustration by Verweij [27].

QCA typically uses case studies in which cause and effect are determined and explained. The conditions are classified as necessary and/or sufficient [19]. Necessary conditions are essential for producing an outcome, though they may require other conditions to be present. Sufficient conditions, on the other hand, can individually produce an outcome, though different sufficient conditions may exist [19]. 
Within QCA, there are two common approaches: a crisp-set approach (indicating conditions and outcomes with only binary coding) and a fuzzy-set approach (indicating a mix of conditions and outcomes that can be dichotomous or have multiple crossover points) [22]. This study makes use of fuzzy-set QCA, as the conditions and outcomes for this study are a mix of dichotomous conditions and conditions with multiple levels of membership (see below).

For its output (so-called solutions), QCA uses Boolean minimization to provide combinations of conditions that are associated with the outcome [19]. This study used two types of solutions: complex solutions that minimize a solution based only on available data and intermediate solutions that use theoretical knowledge to evaluate what conditions would be feasible to include in practice [22].

QCA requires five steps. First, a dataset is chosen that includes data on all relevant conditions and the outcome. Second, the dataset is calibrated, which means that cases are coded according to the degrees of membership present in a condition or outcome. Third, an analysis of necessity is performed to identify conditions that are required for the outcome to occur. Fourth, an analysis of sufficiency is performed by constructing a truth table and minimizing it through Boolean algebra to identify the combinations of conditions that are associated with the outcome. Finally, the combinations of conditions are assessed according to their consistency and coverage. Those that are sufficiently consistent are then compared to established theoretical knowledge to understand why the combination is associated with the outcome.

\section{Data Collection}

This study synthesizes the findings of the policy analyses by EDUCAUS, which comprises descriptive data on individual policies of the 20 investigated EU Member States [12-17]. Information in each case was collected by means of a scoping review [28,29] of the respective national policy repository and analyzed through a path dependence analysis [30]. The primary aim of the EDUCAUS project was to map autism policy with regards to education in general in the EU. They stated in their analyses that, in case autism-specific policy was missing, general SEN policy was identified. Table 1 shows that 17 out of 30 legislative regions (56.67\%) do not address autism specifically in their policy environment. 
From the remaining 13 regions, six $(20 \%)$ developed one or more autism strategies that set priorities for future policy development and seven (23.33\%) implemented policies that set out specific provisions for children with autism. Regardless, both approaches were enrichments on top of general SEN policy. As such, their dataset describes a robust repository of policies that affect the right and access to education for children with autism.

Table 1. The extent of autism policy present in European Union Member States.

\begin{tabular}{|c|c|c|}
\hline Autism Policy & Autism Strategy & General SEN Policy \\
\hline Cyprus & Belgium-Flanders & Austria \\
\hline England $^{1}$ & France & Belgium-German community \\
\hline Germany & Lithuania & Belgium-Wallonia \\
\hline Luxembourg & Scotland $^{1}$ & Czech Republic \\
\hline Malta & Spain & Denmark \\
\hline Northern Ireland $^{1}$ & Wales $^{1}$ & Estonia \\
\hline \multirow[t]{11}{*}{ Slovenia } & & Finland \\
\hline & & Germany-Bavaria \\
\hline & & Germany-Lower Saxony \\
\hline & & Germany-North Rhein Westphalia \\
\hline & & Germany-Saxony \\
\hline & & Hungary \\
\hline & & Latvia \\
\hline & & Netherlands \\
\hline & & Poland \\
\hline & & Slovakia \\
\hline & & Sweden \\
\hline
\end{tabular}

\footnotetext{
${ }^{1}$ Exited the European Union after the data collection and analysis of this country was completed.
}

Our selection of conditions is based on the items included in the DREM and previous research on factors that influenced the development and implementation of IE practices from different perspectives. Since ambiguous terminology can form a barrier of implementation [31] and SEN includes various definitions [1,32-34], having an established definition of SEN is taken as the first condition. The DREM points out that, at a national level, teacher training, child-centered pedagogy, collaborations, sensitization, community involvement, and representation are key for developing IE [8]. It also establishes that basic human rights, such as the rights to health and education, need to be met at the international level. Since the implementation of the right to education occurs at the national level in the EU [35], it is included as the second condition. Teacher training, collaborations, and sensitization are grouped as a third condition as they all relate to the teacher infrastructure, which is a key 
element in IE [4]. The right to health is partially covered by general support services for SEN [36], so their availability is taken as the fourth condition. Policy stands at the center of the national level in the DREM as a factor that enables IE by providing basic conditions needed for IE to be effective. As such, we the presence of IE policy is included as fifth condition. The DREM also explains that community involvement is crucial in the effectiveness of IE. This is restated by Van Mieghem and colleagues [4] and Hehir and colleagues [5], who indicate that the attitude the community (specifically parents) has, is very influential to whether IE practices are developed, implemented, and effective. In particular, it is emphasized that parents need to be included as key partners in their children's education to help ensure the best outcomes [5]. Therefore, parental involvement is included as the sixth condition. Literacy, satisfaction, and accommodation/adaptation are integral factors in the local level of the DREM. They indicate that children should be connected with the contents of school curricula, that they should be motivated to learn, and that appropriate accommodations and adaptations to the learning environment are required (e.g. instructional adaptations to facilitate diverse learning styles). Individualized learning outcomes are a measure in which children can develop according to their own strengths, which is a key factor in IE practices [4]. As such, the presence of individualized learning outcomes is added as seventh condition. Finally, mixed classes in which children with and without SEN are added together form the basis of an IE environment [4,5]. As such, the presence of mixed mainstream classes is the final condition.

We coded the eight conditions as follows: (1) establishment of a definition of SEN (yes or no), (2) the right to education for children with SEN (yes or no), (3) support for teaching staff (none - 0, limited, elaborate - 2), (4) general support services for children with SEN (yes or no), (5) IE policies (yes or no), (6) parental involvement (no - 0, passive, active - 2), (7) individualized learning outcomes (yes or no), and (8) mixed mainstream classes (yes or no). The outcome was access to education (exclusion - 0, segregation, integration, inclusion - 3) [5]. The calibration criteria of conditions and outcome is shown in Table 2, along with information on the characteristics of each condition and what elements had to be present in a policy in order to be allocated a respective value. 
Table 2. Conditions and outcomes, descriptors and sources, and data calibration.

\begin{tabular}{|c|c|c|c|}
\hline Condition/Outcome & Calibration & Criteria & Abbreviation \\
\hline $\begin{array}{l}\text { Condition: Established definition of } \\
\text { SEN }\end{array}$ & No (0), Yes (1) & $\begin{array}{l}\text { Yes, if a definition of SEN is established } \\
\text { through policy. }\end{array}$ & DefSEN \\
\hline $\begin{array}{l}\text { Condition: Right to education for } \\
\text { children with SEN }\end{array}$ & No (0), Yes (1) & $\begin{array}{l}\text { Yes, if the right to education for children } \\
\text { with SEN is established through policy. }\end{array}$ & EduSEN \\
\hline Condition: Support for teaching staff & $\begin{array}{l}\text { None (0), Scarce (1), } \\
\text { Elaborate (2) }\end{array}$ & $\begin{array}{l}\text { Scarce support is indicated by either the } \\
\text { presence of additional teacher training or } \\
\text { supporting staff (e.g. teacher assistants); } \\
\text { elaborate support is indicated by the } \\
\text { presence of both those factors. }\end{array}$ & TeachSup \\
\hline $\begin{array}{l}\text { Condition: Support services for } \\
\text { children with SEN }\end{array}$ & No (0), Yes (1) & $\begin{array}{l}\text { Yes, if support services for children with } \\
\text { SEN are established through policy. }\end{array}$ & SupServ \\
\hline $\begin{array}{l}\text { Condition: Inclusive education } \\
\text { policies }\end{array}$ & No (0), Yes (1) & $\begin{array}{l}\text { Yes, if policies specifically target the } \\
\text { development of inclusive education. }\end{array}$ & IEP \\
\hline Condition: Parental involvement & $\begin{array}{l}\text { None (0), Passive (1), } \\
\text { Active (2) }\end{array}$ & $\begin{array}{l}\text { Passive parental involvement is } \\
\text { characterized by only informing parents of } \\
\text { the child's progress in schools, while active } \\
\text { involvement is a reciprocal relationship } \\
\text { between schools and parents in order to } \\
\text { optimize the learning environment for the } \\
\text { child. }\end{array}$ & Parent \\
\hline $\begin{array}{l}\text { Condition: Individualized learning } \\
\text { outcomes }\end{array}$ & No $(0)$, Yes (1) & $\begin{array}{l}\text { Yes, if there is a system in place that } \\
\text { allows children with SEN to have an } \\
\text { educational trajectory that deviates from } \\
\text { the trajectory that typical children follow. }\end{array}$ & ILO \\
\hline $\begin{array}{l}\text { Condition: Mixed mainstream } \\
\text { classes }\end{array}$ & No (0), Yes (1) & $\begin{array}{l}\text { Yes, if children with SEN are admitted to } \\
\text { mainstream classes in any form. }\end{array}$ & MMC \\
\hline $\begin{array}{l}\text { Outcome: Level of access to } \\
\text { education }\end{array}$ & $\begin{array}{l}\text { Exclusion (0), Segregation } \\
\text { (1), Integration (2), } \\
\text { Inclusion (3) }\end{array}$ & $\begin{array}{l}\text { Exclusion refers to the situation in which } \\
\text { children with SEN are barred from } \\
\text { education entirely; segregation involves } \\
\text { children with SEN being education in } \\
\text { separate facilities; integration means that } \\
\text { children with SEN able to follow } \\
\text { mainstream education do so in } \\
\text { combination with out-of-class support; and } \\
\text { inclusion is defined by the systematic } \\
\text { introduction of children with SEN in } \\
\text { mainstream classrooms where they also } \\
\text { receive the necessary support in that } \\
\text { classroom. }\end{array}$ & AccEdu \\
\hline
\end{tabular}

\section{Statistical Analysis}

The analysis was performed using R [37] and the 'QCA' package [38]. Six out of seven calibrated conditions were tested for necessity. The right to education for children with SEN was excluded from this analysis since it was always present. Conditions were only labelled as necessary when their consistency was greater than 0.90 [39]. Subsequently, a truth table was constructed to identify sufficient causal pathways. This is an intermediate action in a QCA that depicts all potential configurations of conditions and the number of cases that show each causal configuration, along with a consistency score for that causal configuration. The standard frequency threshold of 1 and consistency threshold of 0.80 were used, indicating a moderately strong relationship with the outcome [39]. The condition "individual learning 
outcomes" was excluded from the analysis of intermediate solutions, because individual learning outcomes can only function properly in a multi-disciplinary environment [40], which are contingent on the "support for teaching staff" condition.

Solution consistency and coverage were calculated based on the findings. Coverage indicates to what degree the causal condition explains the outcome. No cut-offs were used, as a lower coverage may identify a less common causal pathway. Intermediate and complex solutions of sufficient conditions from the truth table analysis are illustrated presented in a table. The analysis and the results were replicated by an independent researcher.

To strengthen the findings of this work, a second, independent researcher also coded the dataset. After comparing the two datasets (shown in Supplementary File 1), we tested for inter-rater reliability and found a crude ratio of $72.22 \%$ (195 out of 270 observations). We also accounted for the possibility of reaching inter-rater agreement by chance by computing Cohen's Kappa [41]. The analysis was performed using R [37], particularly using the 'irr' package [42]. A value of 0.533 was found for Cohen's Kappa, which indicates a moderate agreement between observers [43]. In order to ensure correctness of the analysis, the results were analyzed through the DREM and compared to findings in modern literature on IE.

\section{Results}

The analysis involved investigating factors that benefit the development of inclusion. The abbreviated truth table of the causal conditions is included in Supplementary File 2. Seven conditions (support for teaching staff, general support services for children with SEN, individualized learning outcomes, parental involvement, an established definition of inclusion, and mixed mainstream classes) were found to have a relationship with the development of IE. The only condition that was removed from the model was the right to education for children with SEN because this was unanimously implemented. As such, since this condition is unanimously present, it signals that it is irrelevant to the outcome. The presence of general support services for children with SEN (consistency 0.97; coverage 0.632 ) and mixed mainstream classes (consistency 0.997 ; coverage 0.65 ) were labeled as necessary conditions. An overview of the necessary conditions and the causal pathways is given in Table 3. 
Table 3. Necessary and sufficient causes for developing inclusive education.

\begin{tabular}{|c|c|c|c|c|c|c|c|c|}
\hline \multirow{3}{*}{\multicolumn{2}{|c|}{ Conditions }} & \multicolumn{2}{|c|}{ Necessary Causes } & \multicolumn{5}{|c|}{ Sufficient Causes } \\
\hline & & & & \multicolumn{5}{|c|}{ Complex Solution } \\
\hline & & & & 1 & 2 & 3 & 4 & 5 \\
\hline \multicolumn{2}{|c|}{ Established definition of SEN } & & & - & $*$ & * & & \\
\hline \multicolumn{2}{|c|}{ Support for teaching staff } & & & & $*$ & $*$ & $*$ & $*$ \\
\hline \multicolumn{2}{|c|}{$\begin{array}{l}\text { General support services for children } \\
\text { with SEN }\end{array}$} & * & & & & & & \\
\hline \multicolumn{2}{|c|}{ Individualized learning outcomes } & & & & $*$ & & - & $*$ \\
\hline \multicolumn{2}{|c|}{ Parental involvement } & & & $*$ & & - & - & $*$ \\
\hline \multicolumn{2}{|c|}{ Inclusive Education Policies } & & & * & $*$ & $*$ & $*$ & * \\
\hline \multicolumn{2}{|c|}{ Mixed mainstream classes } & & $*$ & & & & & \\
\hline \multirow[t]{2}{*}{ Condition } & Consistency & 0.97 & 0.997 & 0.948 & 1 & 1 & 1 & 1 \\
\hline & Coverage & 0.632 & 0.65 & 0.374 & 0.061 & 0.087 & 0.148 & 0.128 \\
\hline \multirow[t]{2}{*}{ Solution } & Consistency & 0.966 & & 0.811 & & & & \\
\hline & Coverage & 0.652 & & 0.691 & & & & \\
\hline
\end{tabular}

Every column of sufficient causes is one separate causal pathway. The conditions in each pathway should be combined with a logical AND.

Based on available data, five causal pathways were identified as sufficient for the development of IE in the complex solution analysis of the truth table. Having no established definition on SEN with parents being involved and policy that focuses on IE in place was found to be the pathway with a high consistency (0.948) and the highest coverage of the complex solutions (0.374). An established definition of SEN, support for teaching staff, individualized learning outcomes, and IE policies was found to have high consistency with the outcome (1.00), though had little coverage (0.061). Having an established definition of SEN, support for teaching staff, and IE policies, but no parental involvement resulted in high consistency (1.00), but also with little coverage (0.087). Support for teaching staff and IE policies combined with a lack of individual learning outcomes and parental involvement yielded a high consistency (1.00), but low coverage (0.148). Finally, support for teaching staff, individual learning outcomes, parental involvement, and IE policies yielded again a high consistency (1.00), but low coverage $(0.128)$. The overall solution consistency $(0.811)$ was high and coverage (0.691) was moderate, indicating that these combinations of conditions produce the outcome in a large proportion of cases and that a moderate proportion of outcomes in these cases are a result of these combinations of conditions. No intermediate solutions that exceeded the consistency threshold of 0.80 were found. 


\section{Discussion}

This study affirms that EU countries unanimously implemented the right to education for children with SEN and shows that seven of the examined factors are associated with an environment of IE in the EU through the perspective of children with autism: an established definition of SEN, support for teaching staff, general availability of support services for children with SEN, individualized learning outcomes, parental involvement, IE policies, and mixed mainstream classrooms. This suggests that various inputs or components in an education system may be key in the development of IE.

There are several benefits to conducting a QCA. First, it identifies an array of patterns that are associated with an outcome measure, which can bring attention to previously unexplored possibilities or approaches to an outcome [44]. Second, it allows the systematic comparison of case studies by calibrating the characteristics of each case study to a format is transparent and replicable [45]. Third, by differentiating between necessary and sufficient conditions, it can aid researchers and policymakers in developing programs that produce successful educational outcomes [24]. Fourth, the fuzzy nature of this analysis is suitable for analyzing outcomes that can be quantified in degrees (in this study: exclusion, segregation, integration, inclusion) [45]. Finally, whereas statistical methods can overlook the rich contextual complexity and causal complexity to achieving an outcome, QCA is suited to partially overcome this difficulty because of its "potential to account for causal complexity and allowing for generalization" [45].

On the other hand, this study has several limitations. First, the dataset of this study is comprised entirely of policy information and holds no information regarding practical settings. As such, practical implications of the policy recommendations later on should be reviewed before considering implementation. Second, cases should be similar in all aspects relevant to the outcome except for the analyzed conditions to be used by a QCA [22]. As such, policies had to be analyzed by generalized characteristics. This makes it so unique elements that can make a policy effective in a certain setting could have been overlooked. Third, the coding of data was performed by an individual researcher. Given the coding was heavily based on the interpretation of qualitative data, the possibility of interpretative bias of ambiguous texts cannot be excluded, regardless of clear explanations being established for the individual conditions. To ameliorate this limitation, the coding was verified by a second, independent researcher and inter-relater agreement scores were calculated. Fourth, several 
conditions were coded in a binary fashion. Even though it provides a clear overview, it also brings with it the risk of overlooking nuances that be important in the interpretation of the outcome of the condition. Fifth, QCA is not a quantitative approach and cannot account for false positives. We ameliorated this by reflecting back on modern literature in the interpretation of the pathways. Sixthly, conclusions about causality should always be made with an abundance of caution, including when using QCA. It is not likely that our study was able to establish a causal relationship between the analyzed conditions and the outcome. Instead, we identified pathways within a dataset to give insight in future areas of development and should be interpreted carefully [44]. Finally, the dataset of EDUCAUS consisted of a combination of a majority general SEN policy and a minority autism-specific policy. As such, the implications of this study should initially be interpreted from an autismperspective. That being said, the large body of general SEN policy makes it so the results of this study can be used in a wider context, beyond autism.

After considering the strengths and weaknesses of the methodology, findings can be interpreted accordingly. The identification of general support services for children with SEN and mixed mainstream classrooms as necessary conditions are consistent with the core fundamentals of IE - which call for children with SEN to join mainstream classrooms and to have their needs addressed (albeit in-class) [4,46]. As such, consistent with the definition of necessary conditions [19], the availability of general support services for children with SEN and mixed mainstream classrooms can be deemed crucial to the development of IE, but not enough on their own.

Even though the combination of necessary conditions with parental involvement, IE policies, and a lack of SEN definition fit in the DREM as a system of inclusion [8], it is more indicative of an integrative education environment in which children with SEN that can adapt to mainstream classrooms are admitted there and receive SEN support predominantly out of classrooms, but can receive it in-class [5]. The place where the support services are delivered remains ambiguous because policies rarely explicitly state the place of delivery [12-17]. Parental involvement, however, was previously found to be key in letting children with SEN experience effective and welcoming educational settings in which their needs are met [5].

Establishing a definition of SEN, support for teaching staff, individualized learning outcomes, and IE policies combined with the necessary conditions point more towards the 
structural adaptation and interdisciplinarity that is required to develop IE and also complies with the DREM $[4,5,8,46]$. While an established definition of SEN and IE policy provide clarity and consistency in the interpretation of these terms, the support for teaching staff is vital in taking pressure off teachers and allowing them to further develop their skillset in working with SEN. This, in turn, is complemented by the individualized learning outcomes in which children can develop according to their own strengths, which is integral to IE [4].

Adding the necessary conditions to an established definition of SEN, support for teaching staff, IE policies, and the absence of individual learning outcomes creates an environment in which teachers are being put in a position to succeed. More specifically, the availability of teacher support, involving support in classrooms (e.g. teaching assistants) and additional education for teachers on specific SEN condition - shown to be more effective than education on inclusion in general [4] - creates an environment where teachers have the opportunity to tend to the needs of individual children more, due to (1) other responsibilities being transferred to assisting staff and (2) an enhanced skillset on how to work with children with SEN. The set definition of SEN makes sure that there is little ambiguity in terminology, which can increase transferability of practices between teachers.

Combining the necessary conditions with support for teaching staff, IE policies, but without individual learning outcomes and parental involvement creates an environment in which everything is focused on the teachers, without input from community members. It enables teachers to be open in their approach to teaching and, by extension, creative in shaping their classroom materials, which is beneficial in addressing the needs of children with SEN [5]. However, the disconnection with the community may result in more difficulties with regards to implementation, since the community is a big factor in creating welcoming education environments for children [5].

The final pathway that involves the combination of the necessary conditions with support for teaching staff, individualized learning outcomes, parental involvement, and IE policies is the closest representation of the DREM in this analysis. Its multifaceted approach of enhancing teacher training, community involvement (through parents), child centered pedagogy (individual learning outcomes), and collaboration (teacher support) are all reflected in the DREM [8]. Additionally, it corresponds with notion that developing IE requires a systemic change compared to the systems of segregation and integration [5]. 
An interesting finding of this study is that support for teaching staff was present in four out of five identified pathways. The only pathway in which it was absent, is the pathway that was more associated with an integrative environment. This is in line with the DREM where teacher training and collaborations are outlined as key factors of IE [8], as well as recent literature that indicates that teachers who are more experienced and have received better training in working with children with SEN are better able to lessen any negative impact of the children with SEN on the behaviour of their typical peers [47]. They are also found to have a more positive attitudes towards IE upon enhancing their skillset and being better prepared to work with children with SEN [4]. That being said, training teachers on SEN holistically was reported to be less effective than providing training on specific SEN [4]. Nevertheless, support for teaching staff being identified as a sufficient condition indicates that, while it can contribute extensively to developing IE, it does so inconsistently, implying that other factors are necessary to be present (e.g. mixed mainstream classrooms and support services for children with SEN).

This line of reasoning is also applicable for the presence of IE policies in all five of the identified pathways. Policy should be a guiding tool for the relevant areas in developing IE. However, for policy to be effective, these other areas need to have both the capacity and willingness to develop towards IE. For instance, IE policy can prescribe that community members should be involved, but if community members do not see the importance of building IE, they will be less inclined to work towards it.

This study has implications for future research. We identified seven key policy areas that can be used as benchmarks in future studies to keep track of the development of IE. The identified conditions were based on state-of-the-art evidence surrounding IE combined with the internationally used DREM $[4,5,8]$.

This study also has two recommendations for IE policy development. Firstly, the results of this study indicate the need for enhanced teacher support networks. There are already some instances where collaborative networks are seen in the EU. In Luxembourg, a framework was created for institutions that worked with children with SEN that included the assistance of psychologists, special education teachers, primary school teachers, other educators and instructors, and nursery school teachers [15]. Latvia implemented provisions that should be present in mainstream and special classrooms based on specific forms of SEN [17], such as 
visual- and hearing impairments, physical disabilities, speech disorders, learning disabilities, mental health problems, and severe mental disabilities or multiple severe disabilities — which are all common co-occurring conditions for autism [10].

Secondly, improving teacher training is also emphasized as a vital point for IE. Various approaches have been found in the EU as well. Finland, for example, adopted a teaching curriculum that includes courses on each potential step of the education system, making it so that every teacher has at least a basic understanding of SEN [14]. Sweden acknowledged the need to address at a system-wide level and at an individual level by distinguishing two types of special education teachers: SEN teachers that focus at the individual level, and special education needs coordinators, who specialize at addressing the education environment as a whole [14]. As such, it is imperative that a course on autism specifically is created for teachers to improve their understanding and ability to work with children with autism, especially since courses on specific conditions are found to be more effective than general courses on SEN and teachers with more training on SEN were found to have better attitudes towards inclusive education [4].

\section{Conclusion}

In short, equipping mainstream schools with approaches to IE that do not impair (ideally enhance) educational quality for students without a diagnosis is vital. Especially given autism is not binary, but a continuous spectrum, many more children than the raw prevalence figures will benefit from an IE approach that works. However, the development of IE is a complex process in which an array of conditions is involved. In this study, provision of support services for children with SEN and mixed mainstream classrooms were identified as core elements of any system that wants to move from exclusion-segregation to integrationinclusion. Additional items were identified that are sufficient for the development of inclusion on their own, though inclusion does not always happen under those circumstances. The outcomes of this paper hold methodological implications, specifically the identification of key policy areas that can be used as benchmarks in future studies to keep track of the development of IE. It also holds policy implications, namely the identification of several topics that could benefit the development of IE. 


\section{References}

1. Banks J, McCoy S. A Study on the Prevalence of Special Educational Needs. Trim; 2011.

2. Council of Europe. Fighting school segregation in Europe through inclusive education: a position paper. 2017 [cited 2020 Feb 12]. Available from: https://rm.coe.int/fightingschool-segregationin-europe-throughinclusive-education-a-posi/168073fb65

3. UNESCO. The Salamanca Statement and Framework for Action on Special Needs Education. 1994 [cited 2018 May 19]. Available from: http://www.unesco.org/education/pdf/SALAMA_E.PDF

4. Van Mieghem A, Verschueren K, Petry K, Struyf E. An analysis of research on inclusive education: a systematic search and meta review. Int J Incl Educ. 2018;1-15. Available from: https://doi.org/10.1080/13603116.2018.1482012

5. Hehir T, Grindal T, Freeman B, Lamoreau R, Borquaye Y, Burke S. A Summary of the Research Evidence on Inclusive Education. São Paulo: Instituto Alana; 2016. Available from: https://www.abtassociates.com/sites/default/files/201903/A_Summary_of_the_evidence_on_inclusive_education.pdf

6. Lai M-C, Anagnostou E, Wiznitzer M, Allison C, Baron-Cohen S. Evidence-based support for autistic people across the lifespan: maximising potential, minimising barriers, and optimising the person-environment fit. Lancet Neurol. 2020 Mar 3 [cited 2020 Mar 27]; Available from: http://www.ncbi.nlm.nih.gov/pubmed/32142628

7. D'alessio S, Watkins A. International Comparisons of Inclusive Policy and Practice: are we talking about the same thing? Res Comp Int Educ. 2009 [cited 2020 Jan 24];4. Available from: www.wwwords.co.uk/RCIE

8. Peters S, Johnstone C, Ferguson P. A Disability Rights in Education Model for evaluating inclusive education. Int J Incl Educ. 2005;9(2):139-60.

9. World Health Organization. Autism spectrum disorders. World Health Organization. 2019.

10. Lai M-C, Lombardo M V, Baron-Cohen S. Autism. Lancet. 2013/10/01. 2014;383(9920):896-910. Available from: https://www.sciencedirect.com/science/article/pii/S0140673613615391?via\%3Dihub

11. Eurostat. Population change - Demographic balance and crude rates at national level. 2018 [cited 2018 Apr 30]. Available from: http://appsso.eurostat.ec.europa.eu/nui/show.do?dataset=demo_gind\&lang=en

12. Roleska M, Roman-Urrestarazu A, Griffiths S, Ruigrok AN V., Holt R, van Kessel R, 
et al. Autism and the right to education in the EU: Policy mapping and scoping review of the United Kingdom, France, Poland and Spain. Jan Y-K, editor. PLoS One. 2018 Aug 30 [cited 2019 Apr 26];13(8):e0202336. Available from:

http://dx.plos.org/10.1371/journal.pone.0202336

13. van Kessel R, Roman-Urrestarazu A, Ruigrok A, Holt R, Commers M, Hoekstra RA, et al. Autism and family involvement in the right to education in the EU: policy mapping in the Netherlands, Belgium and Germany. Mol Autism. 2019 Dec 9 [cited 2019 Dec 11];10(1). Available from:

https://molecularautism.biomedcentral.com/articles/10.1186/s13229-019-0297-x

14. van Kessel R, Walsh S, Ruigrok AN V., Holt R, Yliherva A, Kärnä E, et al. Autism and the right to education in the EU: policy mapping and scoping review of Nordic countries Denmark, Finland, and Sweden. Mol Autism. 2019 Dec 11 [cited 2019 Dec 14];10(1). Available from:

https://molecularautism.biomedcentral.com/articles/10.1186/s13229-019-0290-4

15. van Kessel R, Hrzic R, Czabanowska K, Baranger A, Azzopardi-Muscat N, Charambalous-Darden N, et al. Autism and the Influence of International Legislation on Small EU Member States: Policy Mapping in Malta, Cyprus, Luxembourg, and Slovenia.

16. Steinhoff $\mathrm{P}$, van Kessel R, Varga O, Breznoščáková D, Czabanowska K, Brayne C, et al. Autism and Teacher Responsibilities in Education in the European Union: Policy Mapping of Austria, Hungary, Slovakia and the Czech Republic.

17. van Kessel R, Dijkstra W, Prasauskiene A, Villeruša A, Czabanowska K, Brayne C, et al. Education for Autistic Children in the EU-Policy Mapping in the Baltic States: Estonia, Latvia, and Lithuania.

18. Franck B, Joshi DK. Including students with disabilities in Education for All: lessons from Ethiopia. Int J Incl Educ. 2017;21(4):347-60.

19. Schneider CQ, Wagemann C. Set-Theoretic Methods for the Social Sciences: A Guide to Qualitative Comparative Analysis. Cambridge: Cambridge University Press; 2012.

20. Rihoux B, Lobe B. The Case for Qualitative Comparative Analysis (QCA): Adding Leverage for Thick Cross-Case Comparison. In: The SAGE Handbook of Case-Based Methods. 1 Oliver's Yard, 55 City Road, London EC1Y 1SP United Kingdom: SAGE Publications Ltd; 2009 [cited 2020 Apr 5]. p. 222-42. Available from:

http://methods.sagepub.com/book/the-sage-handbook-of-case-based-methods/n13.xml

21. Bandelow NC, Vogeler CS, Hornung J, Kuhlmann J, Heidrich S. Learning as a 
Necessary but Not Sufficient Condition for Major Health Policy Change: A Qualitative Comparative Analysis Combining ACF and MSF. J Comp Policy Anal Res Pract. 2019 Mar 15 [cited 2020 Jan 24];21(2):167-82. Available from: https://www.tandfonline.com/doi/full/10.1080/13876988.2017.1393920

22. Rihoux B, Ragin C. Configurational Comparative Methods: Qualitative Comparative Analysis (QCA) and Related Techniques. New York: SAGE Publications; 2009 [cited 2020 Jan 28]. Available from: http://methods.sagepub.com/book/configurationalcomparative-methods

23. Ragin CC. The comparative method. Moving beyond qualitative and quantitative strategies. Los Angeles: University of California Press; 1987.

24. Kane H, Lewis MA, Williams PA, Kahwati LC. Using qualitative comparative analysis to understand and quantify translation and implementation. TBM. 2014 [cited 2020 Jan 24];4:201-8. Available from:

https://www.ncbi.nlm.nih.gov/pmc/articles/PMC4041929/pdf/13142_2014_Article_25 1.pdf

25. Verweij S, Gerrits LM. Understanding and researching complexity with Qualitative Comparative Analysis: Evaluating transportation infrastructure projects. Evaluation. 2013;19(1):40-55.

26. Warren J, Wistow J, Bambra C. Applying qualitative comparative analysis (QCA) in public health: a case study of a health improvement service for long-term incapacity benefit recipients. J Public Health (Bangkok). 2013 [cited 2020 Jan 28];36(1):126-33. Available from: https://academic.oup.com/jpubhealth/articleabstract/36/1/126/1571864

27. Verweij S. Introduction of Qualitative Comparative Analysis (QCA): Morning Session: The Basics of QCA as an Approach. Jülich; 2015 [cited 2020 Feb 16]. Available from: https://www.tias-web.info/wp-content/uploads/2015/07/2015-11-03Presentation-QCA-Basics-Published.pdf

28. Arksey H, O’Malley L. Scoping studies: towards a methodological framework. Int J Soc Res Methodol. 2005 Feb [cited 2018 Apr 25];8(1):19-32. Available from: http://www.tandfonline.com/doi/abs/10.1080/1364557032000119616

29. Levac D, Colquhoun H, O'Brien KK. Scoping studies: advancing the methodology. Implement Sci. 2010 Dec 20 [cited 2018 Apr 25];5(1):69. Available from: http://www.ncbi.nlm.nih.gov/pubmed/20854677

30. Mahoney J. Path dependence in historical sociology. Theory Soc. 2000;29(4):507-48. 
Available from:

http://webarchiv.ethz.ch/soms/teaching/OppFall09/MahoneyPathDependence.pdf

31. Dell'Anna S, Pellegrini M, Ianes D. Experiences and learning outcomes of students without special educational needs in inclusive settings: a systematic review. Int J Incl Educ. 2019;1-16. Available from: https://doi.org/10.1080/13603116.2019.1592248

32. Pijl SJ, Frostad P, Flem A. The social position of pupils with special needs in regular schools. Scand J Educ Res. 2008;52(4):387-405.

33. Dijk W Van, Verheul I, Klompe M. Zorgleerlingen en de PCL. Een onderzoek naar het functioneren van de PCL en de kenmerken van zorgleerlingen [Special educationial needs and the Permanent Committee for Student Care]. Utrecht; 2003.

34. Lindsay G. Educational psychology and the effectiveness of inclusive education/mainstreaming. Br J Educ Psychol. 2007;77(1):1-24.

35. European Commission. Treaty on the Functioning of the European Union. 2009. Available from: http://eur-lex.europa.eu/legalcontent/EN/TXT/PDF/?uri=CELEX:12012E/TXT

36. Carroll J, Bradley L, Crawford H, Hannant P, Johnson H, Thompson A. SEN support: A rapid evidence assessment. 2017.

37. R Core Team. R: A Language and Environment for Statistical Computing. Vienna, Austria; 2018. Available from: https://www.r-project.org/

38. Dusa A. QCA with R. A Comprehensive Resource. Cham, Switzerland: Springer International Publishing; 2019.

39. Garson GD. Case Study Analysis \& QCA. Asheboro, NC: Statistical Associates Publishers; 2016.

40. Johnstone C. The Role of Individualized Learning Plans (ILPs) in Inclusive Education. In: Inclusive Education Strategies: A Textbook. Minneapolis, MN, USA: University of Minnesota; 2018. p. 85-104.

41. Cohen J. A Coefficient of Agreement for Nominal Scales. Educ Psychol Meas. 1960 Apr 2 [cited 2019 Aug 2];20(1):37-46. Available from: http://journals.sagepub.com/doi/10.1177/001316446002000104

42. Gamer M, Lemon J, Fellows I, Singh P. Various Coefficients of Interrater Reliability and Agreement. 2012 [cited 2020 Jun 5]. Available from: https://cran.rproject.org/web/packages/irr/irr.pdf

43. Landis JR, Koch GG. The Measurement of Observer Agreement for Categorical Data. Biometrics. 1977 Mar [cited 2020 Jun 5];33(1):159. Available from: 
https://www.jstor.org/stable/2529310

44. Lucas SR, Szatrowski A. Qualitative comparative analysis in critical perspective. Sociol Methodol. 2014;44(1):1-79.

45. Pattyn V, Molenveld A, Befani B. Qualitative Comparative Analysis as an Evaluation Tool: Lessons From an Application in Development Cooperation. Am J Eval. 2019 Mar 28 [cited 2020 Apr 2];40(1):55-74. Available from: http://journals.sagepub.com/doi/10.1177/1098214017710502

46. Kurth JA, Gross M. The Inclusion Toolbox: Strategies and Techniques for all Teachers. California: Corwin Press; 2014.

47. Gottfried MA. Classmates With Disabilities and Students' Noncognitive Outcomes. Educ Eval Policy Anal. 2014 Mar 1 [cited 2020 Jun 4];36(1):20-43. Available from: http://journals.sagepub.com/doi/10.3102/0162373713493130

\section{Additional Files}

File Name: Additional File 1.

File Format: Excel File (.xlsx)

Title of Data: The datasets as coded by the two independent researchers.

Description of Data: An overview of how the two observers coded the policy data used in the study. 
Dataset Observer 1

\begin{tabular}{|c|c|c|c|c|c|c|c|c|c|c|}
\hline & DefSEN & EduSEN & $N$ TeachSu & & SupServ & ILO & Parent & IEP & MMC & AccEdu \\
\hline Austria & 0 & 0 & 1 & 2 & 1 & 1 & 1 & 1 & 1 & 2 \\
\hline Belgium-Flanders & 0 & 0 & 1 & 1 & 1 & 1 & 3 & 1 & 1 & 2 \\
\hline Belgium-German Community & 0 & 0 & 1 & 1 & 1 & 1 & 2 & 0 & 1 & 1 \\
\hline Belgium-Wallonia & 0 & b & 1 & 1 & 1 & 1 & 2 & 1 & 1 & 2 \\
\hline Cyprus & 0 & 0 & 1 & 3 & 1 & 1 & 2 & 1 & 1 & 3 \\
\hline Czech Republic & 1 & 1 & 1 & 2 & 1 & 1 & 1 & 1 & 1 & 3 \\
\hline Denmark & 0 & 0 & 1 & 2 & 1 & 1 & 2 & 1 & 1 & 2 \\
\hline Estonia & 1 & 1 & 1 & 2 & 1 & 1 & 2 & 1 & 1 & 2 \\
\hline Finland & 0 & 0 & 1 & 3 & 1 & 1 & 3 & 0 & 1 & 3 \\
\hline France & 0 & 0 & 1 & 1 & 1 & 1 & 1 & 1 & 1 & 2 \\
\hline Germany & 0 & 0 & 1 & 1 & 1 & 1 & 2 & 1 & 1 & 2 \\
\hline Germany-Bavaria & 0 & b & 1 & 1 & 1 & 1 & 2 & 1 & 1 & 2 \\
\hline Germany-Lower Saxony & 0 & 0 & 1 & 1 & 1 & 1 & 2 & 1 & 1 & 2 \\
\hline Germany-Nordrhine Westphalia & 1 & 1 & 1 & 1 & 1 & 1 & 2 & 1 & 1 & 2 \\
\hline Germany-Saxony & 0 & b & 1 & 1 & 1 & 1 & 2 & 0 & 1 & 2 \\
\hline Hungary & 0 & 0 & 1 & 3 & 1 & 1 & 2 & 1 & 1 & 2 \\
\hline Latvia & 0 & 0 & 1 & 3 & 1 & 1 & 2 & 1 & 1 & 2 \\
\hline Lithuania & 1 & 1 & 1 & 0 & 1 & 1 & 1 & 1 & 1 & 2 \\
\hline Luxembourg & 0 & 0 & 1 & 2 & 1 & 1 & 2 & 1 & 1 & 3 \\
\hline Malta & 1 & 1 & 1 & 1 & 1 & 1 & 2 & 0 & 1 & 3 \\
\hline Netherlands & 0 & b & 1 & 0 & 1 & 1 & 2 & 1 & 1 & 2 \\
\hline Poland & 0 & 0 & 1 & 0 & 0 & 0 & 1 & 0 & 1 & 2 \\
\hline Slovakia & 1 & 1 & 1 & 2 & 1 & 1 & 1 & 1 & 1 & 2 \\
\hline Slovenia & 1 & 1 & 1 & 2 & 1 & 1 & 2 & 0 & 0 & 1 \\
\hline Spain & 0 & 0 & 1 & 0 & 1 & 1 & 1 & 1 & 1 & 2 \\
\hline Sweden & 0 & 0 & 1 & 2 & 1 & 1 & 2 & 1 & 1 & 3 \\
\hline United Kingdom-England & 0 & 0 & 1 & 2 & 1 & 1 & 1 & 0 & 1 & 3 \\
\hline United Kingdom-Northern Ireland & 0 & 0 & 1 & 0 & 1 & 1 & 2 & 0 & 1 & 2 \\
\hline United Kingdom-Scotland & 0 & b & 1 & 0 & 1 & 1 & 1 & 0 & 1 & 2 \\
\hline United Kingdom-Wales & 0 & 0 & 1 & 0 & 1 & 1 & 1 & 0 & 1 & 2 \\
\hline
\end{tabular}




\begin{tabular}{|c|c|c|c|c|c|c|c|c|c|c|}
\hline & DefSEN & EduSEN & TeachSup & & SupServ & ILO & Parent & IEP & MMC & AccEdu \\
\hline Austria & 0 & 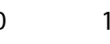 & 1 & 1 & 1 & 1 & 0 & 1 & 1 & 2 \\
\hline Belgium-Flanders & 0 & 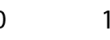 & 1 & 0 & 1 & 0 & 0 & 1 & 1 & 2 \\
\hline Belgium-German Community & 1 & 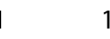 & 1 & 0 & 1 & 0 & 0 & 1 & 1 & 2 \\
\hline Belgium-Wallonia & 0 & 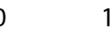 & 1 & 0 & 1 & 0 & 0 & 1 & 1 & 2 \\
\hline Cyprus & 0 & 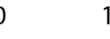 & 1 & 2 & 1 & 1 & 0 & 1 & 1 & 2 \\
\hline Czech Republic & 1 & l & 1 & 2 & 1 & 1 & 0 & 1 & 1 & 3 \\
\hline Denmark & 0 & 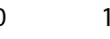 & 1 & 1 & 1 & 1 & 2 & 0 & 0 & 2 \\
\hline Estonia & 0 & 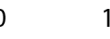 & 1 & 0 & 1 & 1 & 2 & 1 & 1 & 2 \\
\hline Finland & 0 & 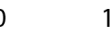 & 1 & 1 & 1 & 1 & 2 & 0 & 1 & 2 \\
\hline France & 0 & 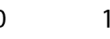 & 1 & 1 & 1 & 0 & 0 & 0 & 1 & 2 \\
\hline Germany & 1 & l & 1 & 0 & 1 & 0 & 0 & 1 & 1 & 2 \\
\hline Germany-Bavaria & 0 & 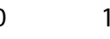 & 1 & 0 & 1 & 0 & 2 & 1 & 1 & 2 \\
\hline Germany-Lower Saxony & 0 & 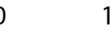 & 1 & 0 & 0 & 0 & 0 & 1 & 1 & 2 \\
\hline Germany-Nordrhine Westphalia & 1 & l & 1 & 0 & 0 & 0 & 2 & 1 & 1 & 2 \\
\hline Germany-Saxony & 0 & 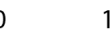 & 1 & 0 & 1 & 0 & 0 & 0 & 0 & 1 \\
\hline Hungary & 1 & 1 & 1 & 1 & 1 & 1 & 2 & 1 & 1 & 2 \\
\hline Latvia & 0 & 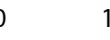 & 1 & 2 & 1 & 1 & 2 & 1 & 1 & 3 \\
\hline Lithuania & 1 & 1 & 1 & 2 & 1 & 1 & 2 & 1 & 1 & 2 \\
\hline Luxembourg & 0 & 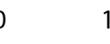 & 1 & 2 & 1 & 1 & 0 & 1 & 1 & 3 \\
\hline Malta & 1 & 1 & 1 & 1 & 1 & 0 & 0 & 0 & 0 & 1 \\
\hline Netherlands & 0 & 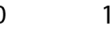 & 1 & 0 & 0 & 1 & 0 & 1 & 1 & 2 \\
\hline Poland & 0 & 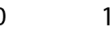 & 1 & 0 & 1 & 1 & 0 & 0 & 1 & 2 \\
\hline Slovakia & 1 & I & 1 & 1 & 1 & 1 & 1 & 1 & 1 & 2 \\
\hline Slovenia & 1 & 1 & 1 & 0 & 1 & 1 & 2 & 0 & 1 & 2 \\
\hline Spain & 0 & 0 & 1 & 1 & 1 & 1 & 0 & 1 & 1 & 2 \\
\hline Sweden & 0 & 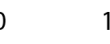 & 1 & 1 & 1 & 1 & 2 & 1 & 1 & 3 \\
\hline United Kingdom-England & 0 & 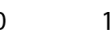 & 1 & 1 & 1 & 1 & 0 & 0 & 1 & 2 \\
\hline United Kingdom-Northern Ireland & 0 & 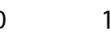 & 1 & 0 & 1 & 1 & 2 & 0 & 1 & 2 \\
\hline United Kingdom-Scotland & 0 & 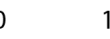 & 1 & 0 & 1 & 1 & 0 & 0 & 1 & 2 \\
\hline United Kingdom-Wales & 0 & 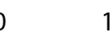 & 1 & 1 & 1 & 1 & 0 & 0 & 1 & 2 \\
\hline
\end{tabular}


File Name: Additional File 2.

File Format: PDF (.pdf)

Title of Data: Truth table corresponding to the analysis on the factors associated with the development of inclusive education.

Description of Data: The truth table that was computed as part of the qualitative comparative analysis that shows all combinations of pathways that are associated with the outcome of inclusion in the data.

\begin{tabular}{ccccccccccc}
\hline Configuration & DefSEN & TeachSup SupServ & ILO & Parent & DefIE & MMC & Outcome & n & \multicolumn{2}{c}{ Consistency } \\
\hline 2 & 0 & 0 & 0 & 0 & 0 & 0 & 1 & 0 & 1 & 0,614 \\
18 & 0 & 0 & 1 & 0 & 0 & 0 & 1 & 0 & 2 & 0,656 \\
20 & 0 & 0 & 1 & 0 & 0 & 1 & 1 & 1 & 1 & 0,900 \\
22 & 0 & 0 & 1 & 0 & 1 & 0 & 1 & 0 & 3 & 0,726 \\
24 & 0 & 0 & 1 & 0 & 1 & 1 & 1 & 1 & 5 & 0,907 \\
28 & 0 & 0 & 1 & 1 & 0 & 1 & 1 & 1 & 1 & 0,840 \\
32 & 0 & 0 & 1 & 1 & 1 & 1 & 1 & 1 & 1 & 1,000 \\
52 & 0 & 1 & 1 & 0 & 0 & 1 & 1 & 1 & 1 & 1,000 \\
56 & 0 & 1 & 1 & 0 & 1 & 1 & 1 & 1 & 3 & 1,000 \\
58 & 0 & 1 & 1 & 1 & 0 & 0 & 1 & 1 & 1 & 1,000 \\
62 & 0 & 1 & 1 & 1 & 1 & 0 & 1 & 1 & 1 & 1,000 \\
64 & 0 & 1 & 1 & 1 & 1 & 1 & 1 & 1 & 3 & 1,000 \\
84 & 1 & 0 & 1 & 0 & 0 & 1 & 1 & 0 & 1 & 0,798 \\
86 & 1 & 0 & 1 & 0 & 1 & 0 & 1 & 1 & 1 & 1,000 \\
88 & 1 & 0 & 1 & 0 & 1 & 1 & 1 & 1 & 1 & 1,000 \\
116 & 1 & 1 & 1 & 0 & 0 & 1 & 1 & 1 & 1 & 1,000 \\
124 & 1 & 1 & 1 & 1 & 0 & 1 & 1 & 1 & 1 & 1,000 \\
125 & 1 & 1 & 1 & 1 & 1 & 0 & 0 & 0 & 1 & 0,115 \\
128 & 1 & 1 & 1 & 1 & 1 & 1 & 1 & 1 & 1 & 1,000 \\
\hline
\end{tabular}




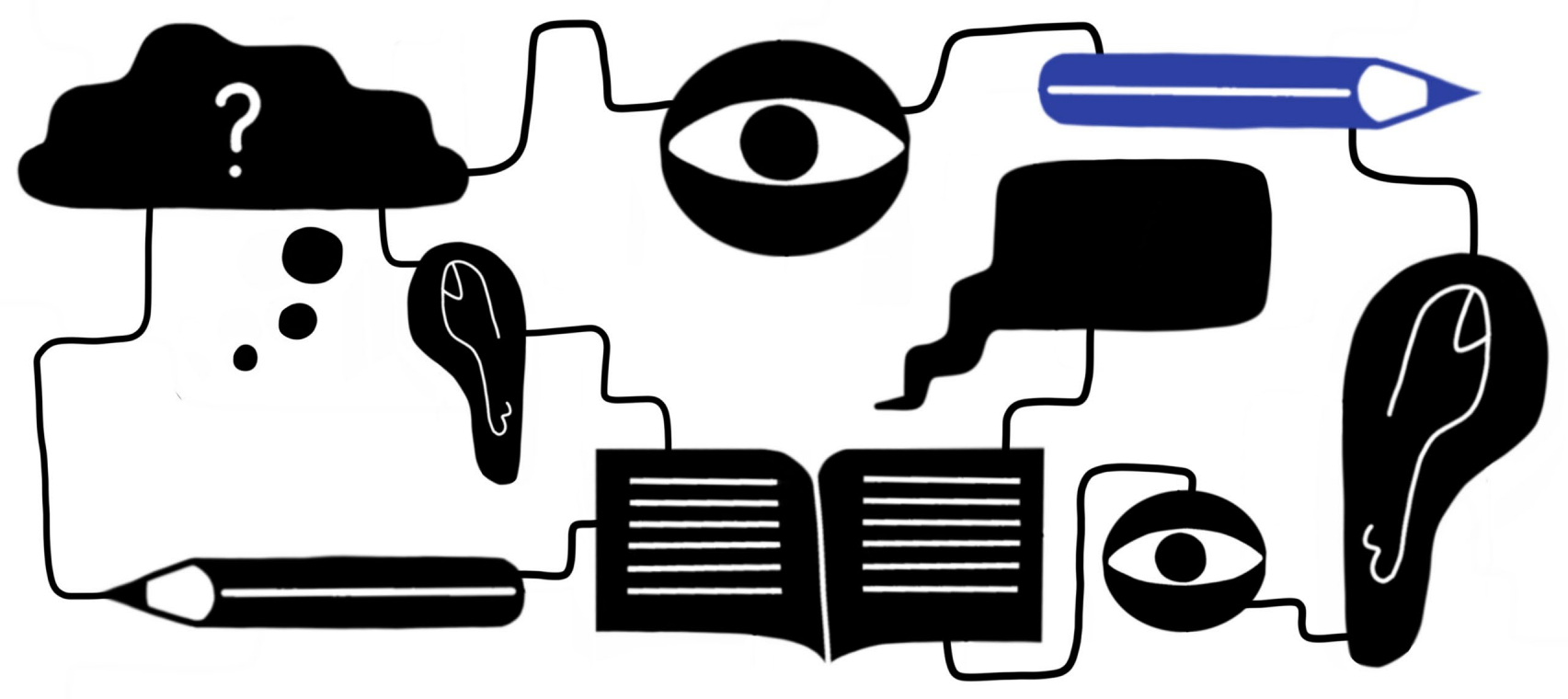

Chapter Seven

General Discussion, Valorisation, and Conclusion 
Autism is a life-long neurodevelopmental condition that is characterized by particularly narrow interests and difficulties in reciprocal social behaviour [1]. Autistic children experience difficulties in various areas in their lives — of particular interest to this thesis being the difficulties in education. These difficulties are often expressed in the form of special education needs (SEN) that have to be addressed properly to allow autistic children to develop themselves as much as possible. Over the last decades, SEN have been approached from various perspectives (e.g. scientific, human rights), as have options for education for children with SEN. This thesis addresses a gap in modern literature by adding an investigation and comparative analysis of the policy environments of 20 out of 28 European Union (EU) Member States in which autism and (special) education policies are explored to determine how the right to education for autistic children is warranted. It further explores pathways for the development of inclusive education for autistic children.

Bringing these perspectives together in a congruous manner is a crucial step to improving the quality of life of children (and adults-to-be) with autism. It would allow autistic children to better develop themselves, prepare for later life, engage more in society, and, by extension, combat the stigma that still surrounds developmental conditions. This thesis focuses on contributing to the education environments for autistic children by analyzing education policies across the EU and identifying good practices and opportunities for growth. In the introductory chapter, the outcomes of the analyses were grouped into five distinct themes that allow better interpretation, discussion, and reflection of the findings of Chapters One through Six: (1) the right to education for autistic children (Right to Education); (2) proper access to education for autistic children (Access to Education); (3) supporting factors that aid autistic children during their years in education - teacher infrastructure and parental involvement (Support); (4) tension that arises either through a change in guiding ideology or a difference in resources and/or policy priorities (Tension); and (5) patterns and trends that are associated with the development of inclusion practices (Trends).

In this final chapter, these themes are individually reviewed first. The main findings are summarized and discussed in the first section-Themes - subdivided under several headings. The heading "Right to Education" reviews the findings of the policy analyses in Chapters One through Five in terms of how the right to education for autistic children is guaranteed internationally and nationally. Subsequently, “Access to Education” examines Chapters One through Five on the extent to which each respective Member State offers inclusion of autistic 
children in their education system. The analysis in this chapter is based on the United Nations (UN) model that distinguishes four dimensions of inclusion. It also emphasizes the results of Chapter Two in particular, where inclusion practices are specifically investigated. "Support" then evaluates the topics discussed in Chapters One, Two, and Three, particularly the involvement of family and teachers in the education of autistic children. "Tension" covers the topics discussed in Chapters Four and Five, which examine the possibility of tension arising by either a change in guiding ideology or a difference in resources and/or policy priorities. "Trends" interprets the findings of the Qualitative Comparative Analysis (QCA) in Chapter Six in light of modern literature and the findings of previous chapters. Lastly, limitations of this thesis are explored and empirical data is reviewed in "Empirical Context" to be able to adequately contextualize the second section-Valorization. This section involves an outline of five distinct scenarios that might occur in the development of education systems. These scenarios are illustrative in nature, aiming to spark discussion and do not consider economic, political, or cultural factors. The thesis is finalized by the third and final section-Conclusion.

\section{Themes}

\section{Right to Education}

Of the 28 EU Member States, 16 were included in Chapters One through Five. On top of that, four were investigated in the work leading up to this thesis [2]. A distinction can be made between international policy that focuses on establishing the right to education for autistic children and national policy that implements that right in the education systems of the respective Member States.

International policy acknowledged that it did not have sovereignty to prescribe any concrete changes. Regardless, Member States that joined the UN (and later the EU) were required to sign the documents and implement them into their national policy, much like an opt-in system. International policy started off crude when comparing it to modern policy. The Universal Declaration of Human Rights [3], a cornerstone document in human rights in general, only declared the right to education for all people affected by it. Subsequent policies [4-6] all reiterated this right for a specific demographic group (children, people with disabilities). The first guidelines were set out in the Salamanca Statement [7] in which the notion of an inclusive education system was firstly mentioned after the acknowledgement of the existence of a wide array of SEN. More recently, the Convention on Rights of Persons 
with Disabilities, which can be considered the modern cornerstone document for human rights for people with disabilities specifically, reiterated the need for an inclusive education environment and for all countries who adopt it to work towards such an environment. Regardless, due to the lack of sovereignty in the area, policy recommendations go as far as establishing rights and pushing for a change in ideology, though do not contain concrete actions to be taken. It does, however, provide for a human rights framework that Member States can use to shape their education systems.

The ratification of the Treaty on the Functioning of European Union [8] resulted in the competence of regulating education being completely delegated to the individual Member States. Policies prior to this Treaty were relatively scarce. Of the four documents, three were mainly focused on establishing rights or addressing discrimination [9-11]. The remaining document involved the Charter of Persons with Autism [12] that emphasizes the need for appropriate education for autistic children, among other things. Post-ratification, the three relevant EU documents consisted of two strategies $[13,14]$ and the General Data Protection Regulation [15]. Both of the strategies involved the improvement of the environment people with disabilities, one by acknowledging that children with SEN are often not included in mainstream education and calling for inclusion, the other focusing on autism in particularcalling for a better holistic understanding of autism. Overall, EU policies share characteristics with UN policies, namely that they can only provide recommendations and guidelines due to the lack in competency. As such, it provides an elaboration of the UN policy framework that helps guide its Member States in developing and formulating their education systems.

National policy was found to be more diverse. Some commonalities were found across all twenty countries. All countries implemented the right to education for autistic children (and children with SEN in general), generally in the early stages of the development of their respective education systems. The implementation of this right was then structurally either paired or closely followed by a policy on anti-discrimination. Finally, after the ratification of the Salamanca Statement and the Convention on Rights of Persons with Disabilities, a trend towards a more inclusive education environment appeared across the investigated Member States. 


\section{Access to Education}

Initially, all countries under study committed to the implementation of different school types to enable all children access to education. This took the form of a distinction between mainstream and special education, especially in the early stages of development after the ratification of the Universal Declaration on Human Rights. More recently, particularly with international policy advocating inclusion, the division between the two school forms has become more variable, which resulted in several possible dimensions of inclusion $[16,17]$.

Analyses of education systems in the European Union (EU) show that modern education systems are typically most closely defined by the "integration" dimension [2,18-21]. However, the definition of this dimension lacks with regard to an explanation what happens with children that are not able to adjust to the mainstream system. As such, a new definition of integration is proposed, which considers all children in an education system, as well as improves the direction it gives countries looking to implement integration in their education system. The full definition is shown in Figure 7.1, along with the other educational dimensions.

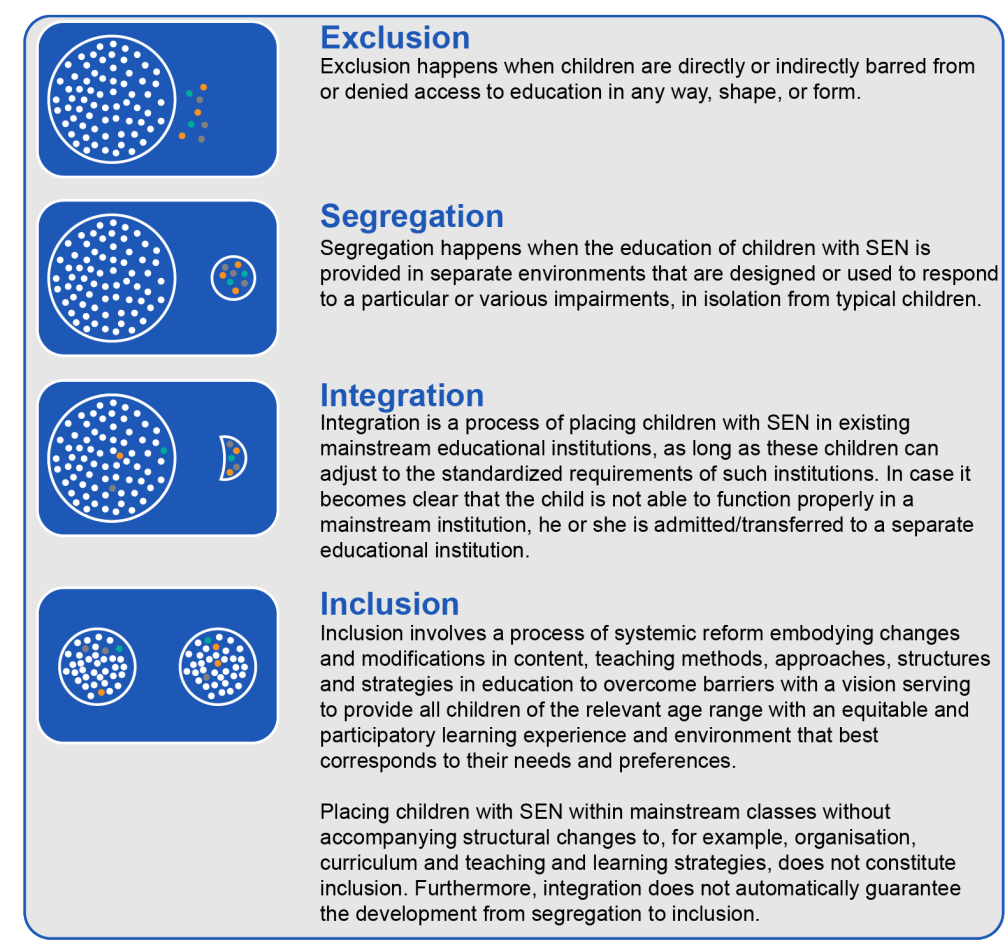

Figure 7.1. An updated version of the four education dimensions based on the depiction by Hehir and colleagues. Source: Adaptation of the Convention on the Rights of Persons with Disabilities General Comment No. 4. 
One notable element that should be discussed is a discrepancy found between education policy analysed in this thesis and employment policy relating to autism in different work. Education policy aims to include everyone in a single environment through the notion of inclusive education. As such, it attempts to equalize as much of the children as possible. Even though it notes that children with SEN should receive guidance according to their needs, it assumes that those needs can be met in the existing iteration of the education system. However, an analysis by Bunt and colleagues of employment policies shows a slightly different approach [22]. While employment policies, much like education policies, state that people with autism (and/or other conditions) should not be discriminated against on work floor, they also recognize that people with autism (or other conditions) may not be able to function optimally if no additional measures are taken. As such, employment policies often allow a measure of "positive discrimination" to exist. In other words, it is, according to (inter)national law, allowed to discriminate for people with autism. While this positive discrimination is somewhat present in education by the notion that children with SEN receive additional support in-class, it fails to recognize the evidence that many SEN come in a spectrum (like autism) and that there will be cases in which a child simply cannot function in mainstream education - inclusive or otherwise.

\section{Support}

The term "support" has multiple interpretations in this thesis. It refers to (1) the support autistic children receive from their parents; (2) the support parents of autistic children receive; (3) the support autistic children receive from teachers; (4) the support teachers receive in learning and understanding how to effectively address autism in a classroom; and (5) the support autistic children receive structurally, such as additional provisions, guidance, etc. The first and second interpretation were covered by Chapter Two, the third was covered by Chapter Four, the fourth by Chapter Three, and the fifth by Chapters Two through Six.

Family involvement can play a key role in policymaking and education [23]. It should be noted that "family" refers the parents and guardians of (autistic) children in this context. When analyzing both international and national policy, the role of family in mainstream education was generally limited to choosing the school in which a child will be admitted. Special education policy elaborated a bit more on the inclusion of parents, though that predominantly involved the education of family. This education then ranged from general 
information sessions to receiving active guidance on how to address the needs of an autistic child at home.

Teachers have been examined in two different aspects, as mentioned above. Firstly, in their role in supporting children in mainstream education, they were found to have been assigned tremendous responsibilities, which are raised even higher among autistic children and children with SEN in general. The four reviewed countries that specifically focused on this matter also all incorporated an array of counselling and supporting staff for their educational counterparts. Secondly, teacher training, investigated in seven reviewed Member States, mostly contains a course on SEN. However, the way this is implemented can differ slightly per Member State. For example, in Denmark, Sweden, and Finland, there are courses included in the teacher curriculum on how to address SEN in a classroom. Slovakia requires teachers in special education and mainstream education that educates children with SEN to have followed specific preparatory programs. The Czech Republic incorporated advisory services in schools and made plans to include training on SEN in teacher curriculum in the near future, but has not done so yet. Latvia prescribes certain that, based on the SEN in a classroom, certain professionals need to be present in the education environment to facilitate their needs and ensure their educational and social inclusion.

Finally, in all reviewed Member States, autistic children are able to receive additional provisions in classrooms. As the trend to include autistic children in mainstream education started and continued on, policy changed to also take additional tools, measures, instruments, etc. that children may need during their education into account. That being said, the measures set out by the reviewed Member States was rarely autism-specific. Instead, it focused on SEN as a whole. While the autism community still benefits from these policies through their access to the services discussed in the policies, it also indicates a lack of specificity being incorporated in national policy that can negatively affect the provision of services to children with complex conditions, such as autism.

\section{Tension}

Two separate forms of tension have been investigated in this thesis: (1) the tension that arises due to the difference in size of Member States when following international guidance; and (2) the tension that arises from a change in ideology, in this case the change from the communist ideology harbored by the former Soviet Union to the UN human rights ideology. 
When analyzing the presence of the first form of tension, it became clear that such tension is present in minor ways, if at all. International guidelines are implemented in large and small sized Member States alike. The observed difference, however, lies in the national education policies. In large-sized Member States, education policy was found to be more elaborate, while small-sized Member States implemented more straightforward iterations. Compared to their larger counterparts - assuming a global prevalence of approximately $1 \%$ [24] and the population sizes reported by Eurostat [25] — the small states of Malta, Cyprus, and Luxembourg host between three and 130 times fewer people and, thus, have to consider a significantly smaller number of autistic children. As such, by considering the difference in burden of disease of autism in these countries, it is justifiable that their policy regarding SEN is less elaborate. Especially since children with SEN are still enabled to follow education. With regards to policies that aim to develop inclusive education, it was found that smaller states tend to mimic the endeavors of their larger peers.

The second form of tension, moving from the communist ideology in the Soviet Union to the UN human rights ideology, required the Member States in question-Estonia, Latvia, and Lithuania - to abolish all policies of the former ideology. The education policies that initially emerged after the adoption of the UN human rights ideology still held traces from the old, communist ideology, especially in regards to the education of children with SEN. It favored the facilities implemented under the Soviet regime (e.g. special schools, special boarding schools, and sanatorium-esque facilities) for the education of children with SEN. However, as the education system developed further, more progressive initiatives were implemented, such as inclusive language and SEN education strategies.

\section{Trends}

All countries in this thesis were investigated individually. Comparisons were drawn among a selection of countries, but the results were not necessarily openly interpretable. As such, the QCA was used to identify patterns and trends in the dataset of the European Consortium for Autism Researchers in Education (EDUCAUS) that indicate beneficial factors for the development of inclusive education for autistic children. The seven analyzed conditions were based on previous research that focused on factors that affect the development of inclusion practices from different perspectives and that reported already established barriers to implementation of inclusion [2,16,18-21,26-29]. These consisted of (1) the right to education 
for autistic children, (2) support for teaching staff, (3) general support services for autistic children, (4) individualized learning outcomes, (5) parental involvement, (6) inclusive education policies, and (7) mixed mainstream classes.

Mixed mainstream classrooms and support services for autistic children were labelled as critical factors to implement for the development of inclusion for autistic children - albeit not sufficient by themselves. Support for teaching staff and inclusive education policies were found to be present in the majority of identified pathways ( $80 \%$ and $100 \%$ respectively) as highly influential factors that could lead to a system of inclusion on their own, albeit inconsistently. In the analysis that lead to these pathways, individual learning outcomes were assumed to be absent, as (1) the EDUCAUS policy analysis showed that current education systems are rarely based on individualized learning outcomes [2,18-21,26] and (2) while individual learning outcomes enable children to develop according to their own strengths and needs — which is a core element in inclusion [27,30] — they require multidisciplinary teams to be established and parents to be properly involved [30], indicating the need for a wider infrastructure than what was found by the EDUCAUS analyses in order to be effective.

\section{Empirical Context}

It has to be noted that the contents of this thesis are inherently limited due to the fact that it solely investigates written policy. Before it is possible to explore options for future recommendations, it is imperative that these written policies are contextualized by empirical data. According to two commonly used tools to analyze policy (Walt and Gilson's policy triangle and Kingdon's multiple streams framework), stakeholder views are vital to the policy development process $[31,32]$. In this section, a summary of stakeholder analyses of the past four years is provided, since these are most likely to reflect modern opinions of stakeholders on the practical state inclusive education and, by extension, of implemented policy. Even though stakeholder data with regards to inclusive education in the EU specifically is scarce, the task of developing inclusive education based on the CRPD and Salamanca Statement is being worked on worldwide.

Two reviews by Van Mieghem and colleagues (systematic) and by Roberts and Simpson (comprehensive) indicate that a generally positive attitude towards inclusion exists [27,33]. Both reports also find that the attitude towards inclusion tends to improve when teachers have more knowledge on how to work with children with SEN. Conversely, many negative 
attitudes towards inclusion exist due to a perceived structural lack of preparation to work with children with SEN. Roberts and Simpson further investigated stakeholder views on the inclusion of autistic children, in which they found that the level of knowledge and understanding of autism and their awareness and ability to use effective strategies were identified as vital factors in determining the success of inclusive education. Interestingly, general education teachers indicated that they did not feel they had sufficient knowledge of autism and effective strategies to adequately work with autistic children. Roberts and Simpson finish by calling for widespread mainstream teacher training on autism and how this would not only directly benefit autistic children, but non-autistic children would then immediately be introduced to good autism practices. This call was based on the notions that "systems-wide initiatives supporting autism inclusion and in-service training about autism and inclusive practices would contribute to success" and "education and training in inclusion and autism was highly prioritized by school leaders and staff themselves suggesting that this should be a priority, if not mandatory, in school systems" [33]. Van Mieghem and colleagues, Roberts and Simpson, and Ruben and colleagues further indicate overwhelming support for partnerships across stakeholders $[27,33,34]$. The stakeholders, in these contexts, consist of teachers, parents, co-teachers/teaching assistants, the schools/educational environment, health professionals, and/or social workers.

Vlachou and Papananou explain that it can also be very valuable to incorporate the voices of the children with the condition in question into the discussion [35]. Roberts and Simpson briefly explored this avenue and found that autistic children generally believed education staff required more extensive knowledge of autism to allow them to be properly included in the school environment.

In short, empirical data in the form of stakeholder analyses indicates that there is a need of improvement in the autism infrastructure. While the contents of the thesis could only infer this need based on theoretical models, these inferences are able to be validated by previously gathered empirical data. 


\section{Valorization}

This thesis identified several vital points that can be used to spearhead the development of inclusive education in the EU. To do this, however, it is important that a shared vision is created among stakeholders (e.g. policy makers, teaching staff, and community members). In the previous section, an overview of stakeholder analyses regarding the development of inclusive education is already provided. Scenario planning involves the definition of a desired, shared vision of the future, as to better prepare professionals to be successful in a constantly shifting environment [36] and has been used by the European Commission before to set the agenda on the future of the European Union [37].

In the QCA, it was explained how availability of SEN services, mixed mainstream classrooms, inclusive education policies, and support for teaching staff (i.e. high-quality education, as well as networks of professionals that provide support) are vital to the development of inclusive education and how the latter three are inconsistently present across the EU. The following scenarios explore various possibilities in terms of decision-making, priority setting, and structural improvement through policy in order to further enhance inclusive education in the EU. The scenarios are illustrative in nature in order to provoke thought and discussion. They are not detailed blueprints or policy prescriptions. They also intentionally do not mention legal or institutional processes - the form will follow the function. The possibilities covered here range from the current situation as-is, to a change of scope and priorities, to a partial or collective leap forward. There are overlaps between scenarios, meaning they are neither mutually exclusive, nor exhaustive. The final outcome will unquestionably be different from the way these scenarios are presented, since education systems differ per country and developing one system requires social, cultural, and national policy characteristics to be accounted for as well.

The starting point of each scenario is an integrative education system in which autistic children that can adapt to mainstream education are admitted. This starting point was chosen because this is the most common educational environment currently present in the EU based on the policy analyses. Afterwards, the rationale behind why and how a scenario would play out, its impact on the education system, and the advantages and disadvantages are discussed. Finally, the policy impacts and some illustrative snapshots of circumstances that could happen in that scenario are displayed. 


\section{Scenario One: Continuing the Current Trajectory}

Why and How?

In a scenario where EU Member States stick to their current course, the education system is incrementally changed to facilitate inclusion and remains integrative rather than inclusive for a long time. This course will likely meet the objectives set out in the Convention on the Rights of Persons with Disabilities, European Disability Strategy 2010-2020, Salamanca Statement, and the Sustainable Development Goals that pertain to inclusion eventually. In doing so, EU Member States continue to combat segregation of education and gradually offer more autistic children the required support. The rate of change depends on the national policy agendas, the support that inclusive education receives at the executive level, and the attitude that the community shows towards the implementation of inclusive education.

\section{Changes to the Education Systems}

This scenario portrays a slow and steady development of inclusive education by augmenting existing policy to slowly introduce a more elaborate infrastructure for teachers and supporting staff. Autistic children who can adapt to mainstream education can continue to participate in mixed classrooms. Those who cannot, however, continue to be segregated in special schools or specialist facilities depending on the country in question.

Teachers remain predominantly responsible for all the in-classroom needs of autistic children. They continue feeling underprepared to work with autistic children as a result of a lack of training and will receive little to no support from other disciplines due to there being no such network established. Consequently, their negative attitudes towards inclusive education persist, though they continue to work in mixed mainstream classrooms. Policy remains non-specific with regards to providing guidance for SEN, particularly autism.

\section{Advantages and Disadvantages}

This scenario builds upon the current education systems that already partially admit autistic children in mainstream classrooms. SEN services are provided outside of these mixed mainstream classrooms, thus enabling autistic children to grow next to their non-autistic peers. This system focuses on optimizing the current system and only resorts to larger changes once a barrier cannot be addressed by the resources in place. Problems that lie under the surface, such as attitudinal and motivational problems, will likely persist, as these are not as easily recognizable as, for example, a problem in infrastructure. 


\section{Impact on Policies}

\begin{tabular}{l|l|l|l}
\multicolumn{1}{c|}{$\begin{array}{c}\text { SEN Services } \\
\text { for Children }\end{array}$} & \multicolumn{1}{c|}{$\begin{array}{c}\text { Mixed } \\
\text { Classrooms }\end{array}$} & $\begin{array}{c}\text { Inclusive } \\
\text { Education Policy }\end{array}$ & \multicolumn{1}{c}{ Teacher Support } \\
\hline $\begin{array}{l}\text { SEN services are } \\
\text { provided outside of } \\
\text { mixed mainstream } \\
\text { classrooms }\end{array}$ & $\begin{array}{l}\text { Mixed mainstream } \\
\text { classrooms are } \\
\text { outlined that autistic } \\
\text { children can attend as } \\
\text { long as they are able to } \\
\text { adapt to the curriculum } \\
\text { set out for all children } \\
\text { in mainstream education }\end{array}$ & $\begin{array}{l}\text { Policies that are aimed } \\
\text { at developing inclusive } \\
\text { education remain non- } \\
\text { specific when addressing } \\
\text { SEN, in particular autism }\end{array}$ & $\begin{array}{l}\text { Teachers remain } \\
\text { responsible for the } \\
\text { needs of autistic } \\
\text { children in their classes; } \\
\text { they are insufficiently } \\
\text { prepared to work with } \\
\text { autistic children; they } \\
\text { receive little to no } \\
\text { support from other } \\
\text { disciplines }\end{array}$ \\
& &
\end{tabular}

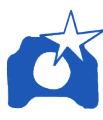

\section{Illustrative Snapshots}

- Autistic children have access to the additional resources they need to meet their educational needs, even though they may have to rely on multiple institutions to acquire them.

- Mainstream education is available for autistic children that can participate by adapting. Children that cannot adapt are moved to specialised facilities where they are educated.

- Little clarity is provided at the policy level on how to work with autistic children. This puts the responsibility to create and develop good practices with teachers and runs the risk of creating an unequal environment in terms of the quality of education and educational practices that are provided to autistic children.

- Teachers are reluctant to actively work with autistic children in mixed mainstream classrooms due to their lack of preparation and training.

- Other experts and disciplines are not actively involved in the education of autistic children. They may be involved outside of education and have an indirect effect, but are not actively present inside of schools. 


\section{Scenario Two: Committing to Inclusion}

Why and How?

In a scenario where EU Member States commit to developing and enhancing inclusive education quicker, more elaborate actions are implemented. This course will more swiftly achieve the objectives of the Convention on the Rights of Persons with Disabilities, European Disability Strategy 2010-2020, Salamanca Statement, and the Sustainable Development Goals surrounding inclusive education. This course is also more focused on the actual development of inclusion in education, rather than improving and further building a system of integration first.

\section{Changes to the Education Systems}

This scenario is characterized by large-scale changes to the education system in a shorter time span. These changes cover renewed and improved teacher training courses, collaborations with other professionals to be able to better address the SEN of a child in a school environment, and specified policies with regards to (clusters of) SEN.

As a result, the transition from integration to inclusion becomes clearer. The negative attitudes of teachers towards inclusive education is mitigated by the improved training courses and multidisciplinary support networks. Due to the active involvement of other professionals in the education of autistic children inside the school environment, pressure is further alleviated from teachers as they can predominantly focus on the educational needs of autistic children. Due to the specific guidelines and best practices outlined in inclusive education policy, a centralised foundation is created upon which the delivery of high-quality education to autistic children is built.

\section{Advantages and Disadvantages}

This scenario acknowledges that systemic changes are required to fully realise an inclusive environment and that teachers alone are not sufficient for such an environment. Addressing health, educational, social, and other needs of autistic children is more streamlined due to the multidisciplinary collaboration inside the school environment. Policies outline best practices and provide clarity on how to work with autistic children. Nevertheless, achieving these goals requires a structural change that goes beyond the school environment and also encompasses teacher training, national policy, and other professional fields. 


\section{Impact on Policies}

\begin{tabular}{l|l|l|l}
\multicolumn{1}{c|}{$\begin{array}{c}\text { SEN Services } \\
\text { for Children }\end{array}$} & \multicolumn{1}{c|}{$\begin{array}{c}\text { Mixed } \\
\text { Classrooms }\end{array}$} & $\begin{array}{c}\text { Inclusive } \\
\text { Education Policy }\end{array}$ & \multicolumn{1}{c}{ Teacher Support } \\
\hline $\begin{array}{l}\text { SEN services are } \\
\text { imbedded in the school } \\
\text { environment and can be } \\
\text { provided swiftly }\end{array}$ & $\begin{array}{l}\text { Mixed classrooms allow } \\
\text { for the uptake of all } \\
\text { autistic children; care can } \\
\text { be provided as necessary } \\
\text { due to the collaborations } \\
\text { between professionals }\end{array}$ & $\begin{array}{l}\text { Policies are specific with } \\
\text { regards to (a group of } \\
\text { SEN and set out best } \\
\text { practices to be used in } \\
\text { education; examples of } \\
\text { bad practice are also } \\
\text { highlighted in policies }\end{array}$ & $\begin{array}{l}\text { Teachers are responsible } \\
\text { for the educational needs } \\
\text { of autistic children in } \\
\text { their classes; they receive } \\
\text { life-long training to } \\
\text { sharpen their } \\
\text { competencies in working } \\
\text { with autistic children; } \\
\text { they are supported by an } \\
\text { array of professionals of } \\
\text { other fields }\end{array}$
\end{tabular}

\section{Illustrative Snapshots}

- The provision of SEN services is incorporated in the school environment and occurs in a collaborative effort between professionals.

- All children on the autism spectrum are able to participate in a mixed classroom, receiving appropriate health and educational support where necessary.

- Policies are designed more elaborately, now including a list of best practices when working with autistic children, such as what professionals should be present in an educational institution to ensure proper provision of SEN services in a school environment. Alternatively, the list can cover best practices when working with children with developmental conditions. Policies also specify bad practices and behaviour to avoid around autistic children/children with developmental conditions.

- Teacher attitudes towards inclusion are improved as a result of the added and improved training they receive as part of their standard teacher training as well as additional courses aimed at life-long learning.

- Psychologists, speech therapists, social workers, physical therapists and other professionals receive training to work in collaboration with teachers in a school environment. 


\section{Scenario Three: Reversing to Segregation}

Why and How?

In a scenario where EU Member States seek to address the more resource-intensive SEN without structurally reforming the education system, a stronger division of the education system in mainstream and special education facilities arises. The course of this scenario strays from the values of the Convention on the Rights of Persons with Disabilities, European Disability Strategy 2010-2020, Salamanca Statement, and the Sustainable Development Goals that pertain to inclusive education and social inclusion.

\section{Changes to the Education Systems}

This scenario is defined by a focus on splitting the education system in mainstream and special education. Autistic children are still able to participate in education, but are separated from their non-autistic peers in special classrooms, where their educational needs are addressed. Policies that pertain to inclusive education are non-existent in this scenario. Teacher training is specified into two categories: (1) teachers that work in mainstream education; and (2) teachers that focus on working in special education.

As a result, the right to education for all children is still intact. Nevertheless, the segregation of children with and without SEN results in a decrease of social uptake of people with disabilities later in life. Negative attitudes towards mixed classrooms diminish as a result of the segregation, as teachers can choose to work with children in either mainstream or special classrooms.

\section{Advantages and Disadvantages}

This scenario acknowledges that autistic children require an array of support that can differ per child. It adapts its education system to provide specialised classrooms in which these children can participate in education and develop themselves. However, this adaptation of the education system to separate autistic children from their typical peers is also detrimental to their social uptake and development, both during their formative years and in later life. This separation may also risk that the negative attitudes are directed to children with mild SEN that are admitted to mainstream classrooms. Effectively, this scenario allows discrimination on the basis of disability to be (re)introduced in the formation of classrooms. 


\section{Impact on Policies}

\begin{tabular}{l|l|l|l}
\multicolumn{1}{c|}{$\begin{array}{c}\text { SEN Services } \\
\text { for Children }\end{array}$} & \multicolumn{1}{c|}{$\begin{array}{c}\text { Mixed } \\
\text { Classrooms }\end{array}$} & $\begin{array}{c}\text { Inclusive } \\
\text { Education Policy }\end{array}$ & \multicolumn{1}{c}{ Teacher Support } \\
\hline $\begin{array}{l}\text { SEN services are } \\
\text { provided in special } \\
\text { schools or facilities where } \\
\begin{array}{l}\text { autistic children also } \\
\text { receive their education }\end{array}\end{array}$ & $\begin{array}{l}\text { Classrooms in special } \\
\text { education facilities } \\
\text { incorporate a range of } \\
\text { children that each has } \\
\text { their unique SEN }\end{array}$ & $\begin{array}{l}\text { Policies that focus on the } \\
\text { development of inclusive } \\
\text { education are non- } \\
\text { existent; policies set out } \\
\text { measures that enforce } \\
\text { a segregated education } \\
\text { environment based on } \\
\text { disability status }\end{array}$ & $\begin{array}{l}\text { Teacher training is split in } \\
\text { training the focuses on } \\
\text { mainstream education and } \\
\text { special education } \\
\text { respectively; teachers are } \\
\text { also assisted by other } \\
\text { staff present in the special } \\
\text { facilities }\end{array}$ \\
& &
\end{tabular}

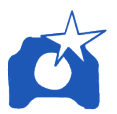

\section{Illustrative Snapshots}

- Autistic children are separated from their typical peers and receive education in a specialised environment that can tend to their individual SEN. SEN service provision is incorporated in these specialised institutions.

- Children with different SEN are admitted together in smaller class sizes in which they are less prone to overstimulation and where they can receive more individual attention from teachers and supporting staff.

- Policies are designed to separate typical children from children with SEN, essentially gauging their capabilities based on disability status.

- Teacher's negative attitudes towards inclusion of autistic children in mixed classrooms dissolves as teachers can now decide whether they are willing to work in mainstream or special classrooms specifically during their teacher training.

- Specialized institutions employ a wide spectrum of professionals in addition to the teachers that aid in taking care of and developing the children admitted to that institution. 


\section{Scenario Four: Intentional Social Distancing}

Why and How?

In a scenario where EU Member States coronavirus disease 19 (COVID-19) pandemic measures remain in place for a prolonged period of time, action is taken to retain the current level of social inclusion and actively adapt the education system to match. This course takes an innovative and adaptive approach to the values of the Convention on the Rights of Persons with Disabilities, European Disability Strategy 2010-2020, Salamanca Statement, and the Sustainable Development Goals.

\section{Changes to the Education Systems}

This scenario shows the adaptability of the education system in the face of public health emergencies through remote-controlled classrooms, smaller in-person class sizes, and clear and direct instructions of expectations and tasks for children. Teachers are supported by teaching assistants, as well as by the parents or caretakers at home, who are actively involved in the education process. Policies specify good practices when working with autistic children (or children with developmental disorders). Other professionals are connected with teachers and children to aid in addressing the non-educational needs of the child and relieve pressure from teachers.

As a result, autistic children still connect with their teacher and their non-autistic peers. The negative attitudes of teachers towards inclusive education are addressed by the involvement of other professionals. Due to the specific guidelines and established good practices in policy, a centralised foundation for the provision of high-quality education is created as well.

\section{Advantages and Disadvantages}

This scenario warrants the continued inclusion of autistic children in mainstream education and can advance that further. It guarantees that autistic children-who are already vulnerable to poor mental health that can be exacerbated by the pandemic [39] — are not further isolated. It both limits the number of changes to the daily routine of autistic children and makes sure the education trajectory of autistic children remains largely uninterrupted. However, this method limits face-to-face contact with teachers and relies heavily on communication through digital means, which may pose a problem for some children that experience difficulties in these areas. 


\section{Impact on Policies}

\begin{tabular}{l|l|l|l}
\multicolumn{1}{c|}{$\begin{array}{c}\text { SEN Services } \\
\text { for Children }\end{array}$} & \multicolumn{1}{c|}{$\begin{array}{c}\text { Mixed } \\
\text { Classrooms }\end{array}$} & $\begin{array}{c}\text { Inclusive } \\
\text { Education Policy }\end{array}$ & \multicolumn{1}{c}{ Teacher Support } \\
\hline $\begin{array}{l}\text { SEN services are } \\
\text { provided remotely or } \\
\text { in rooms specifically } \\
\text { set up for in-person } \\
\text { contact }\end{array}$ & $\begin{array}{l}\text { Mixed classrooms are } \\
\text { further enhanced due to } \\
\text { the general limitation of } \\
\text { the number of children } \\
\text { that are allowed to be } \\
\text { present in a single } \\
\text { classroom }\end{array}$ & $\begin{array}{l}\text { Policy is focused on } \\
\text { prescribing good } \\
\text { practices for working with } \\
\text { autistic children remotely }\end{array}$ & $\begin{array}{l}\text { Teacher training includes } \\
\text { a course on remote } \\
\text { education; specialist } \\
\text { courses are provided for } \\
\text { specific conditions; } \\
\text { professionals are } \\
\text { connected with teachers } \\
\text { to support them in } \\
\text { working with autistic } \\
\text { children remotely }\end{array}$ \\
& &
\end{tabular}

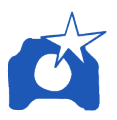

\section{Illustrative Snapshots}

- SEN services are provided remotely as much as possible. Only when necessary are specialised rooms prepared in which autistic children can freely interact with the professonial.

- Due to the reduced class sizes, autistic children can more easily join the mixed classrooms. Further measures to facilitate inclusion are taken in the forms of regular check-ups and remote assistance of parents and children by teachers and professionals.

- Policies' aim is keeping the education system as remote as possible and focuses on communicating good practices that can be performed through remote classes or at a safe distance.

- As a result of the improved teacher training curriculum, the negative attitude regarding inclusive education and mixed classrooms is minimal. This is further expanded by the involvement of professionals to work with both teachers and children to divide the responsibilities for addressing health and education needs. 


\section{Scenario Five: Slow Response to Social Distancing}

Why and How?

In a scenario where EU Member States keep the COVID-19 measures in place intermittently due to fluctuations in the spread of disease, teaching infrastructure can be insufficiently supported and adapted to the new environment in which teachers have to shift between inperson and remote teaching. As a result, autistic children run the risk of receiving insufficient assistance or provision of SEN services to ensure continuity of high-quality education. The course of this scenario deviates from the values of the Convention on the Rights of Persons with Disabilities, European Disability Strategy 2010-2020, Salamanca Statement, and the Sustainable Development Goals that pertain to inclusive education and social inclusion.

\section{Changes to the Education Systems}

This scenario shows marginal changes to the education system and attempts to pursue the same course as Scenario One. However, the frequent yet irregular shifts between in-person and remote provision of education and SEN services result in the creation of policy that lags behind the current situation and does not address remote teaching infrastructure in a timely manner.

Teachers remain primarily in charge of the provision of SEN in addition to education and they are insufficiently trained to switch between providing education in-person and remotely. Their already existing feelings of unpreparedness are exacerbated by the new and chaotic circumstances. Negative attitudes towards inclusive education can increase due to these added complications. Policy remains non-specific with regards to providing guidance for SEN, particularly autism.

\section{Advantages and Disadvantages}

This scenario, like Scenario One, builds upon the current education systems that already partially admit autistic children in mainstream classrooms and focuses on optimizing the current system and only resorts to larger changes once a barrier cannot be addressed by the resources in place. This approach, however, can lead to a lack of established clarity and additional resources for teachers to continue to offer high-quality education. As a result, it is not only detrimental to the continuity of education of autistic children, but also to their mental health, especially considering they are already at heightened risk of mental ill-health [38]. 


\section{Impact on Policies}

\begin{tabular}{|c|c|c|c|}
\hline $\begin{array}{l}\text { SEN Services } \\
\text { for Children }\end{array}$ & $\begin{array}{c}\text { Mixed } \\
\text { Classrooms }\end{array}$ & $\begin{array}{c}\text { Inclusive } \\
\text { Education Policy }\end{array}$ & Teacher Support \\
\hline $\begin{array}{l}\text { Over time, a system in } \\
\text { which SEN services can } \\
\text { be provided in-person and } \\
\text { remotely are created } \\
\text { to ensure continuity }\end{array}$ & $\begin{array}{l}\text { Mixed classrooms exist in } \\
\text { which autistic children } \\
\text { can develop themselves } \\
\text { next to their non-autistic } \\
\text { peers; children that cannot } \\
\text { adapt to a mixed } \\
\text { classroom are moved to a } \\
\text { separate facility }\end{array}$ & $\begin{array}{l}\text { Due to the frequent, yet } \\
\text { irregular shiftsbetween } \\
\text { in-person and remote } \\
\text { education, the } \\
\text { development of policy } \\
\text { that addresses the } \\
\text { combination of both } \\
\text { circumstances is slow }\end{array}$ & $\begin{array}{l}\text { Teacher remain } \\
\text { responsible for the SEN } \\
\text { of the autistic children in } \\
\text { their classes; teacher } \\
\text { training is not adapted to } \\
\text { account for the remote } \\
\text { environment; other } \\
\text { professionals are not } \\
\text { involved in the education } \\
\text { trajectory }\end{array}$ \\
\hline
\end{tabular}

\section{Illustrative Snapshots}

- SEN services are intended to be provided remotely or in-person. However, due to constant shifts between the two approaches, provision of services is chaotic and inconsistent.

- Mixed classrooms continue to exist remotely and in-person where autistic and non-autistic children co-develop. Class sizes remain unchanged due to the frequent shift to the standard environment.

- Policies remain non-specific with regards to autism (or developmental conditions as a cluster) and split focus between developing the education system on par with the intended course (see Scenario One) and adjusting to the new circumstances of frequently and irregularly shifting between in-person and remote teaching.

- Teachers are not specifically (re)trained to work with children with SEN remotely. Attitudes regarding the inclusion of children with SEN in mainstream education as a whole further deteriorate.

- Professionals are neither (re)trained for nor included in providing SEN services remotely, further risking inconsistent service delivery. 


\section{Moving Forward}

The inclusion of people with disabilities in education and in wider society has become an increasing priority after the implementation of the Universal Declaration of Human Rights, the Convention on the Rights of Persons with Disabilities, European Disability Strategy 2010-2020, Salamanca Statement, and the Sustainable Development Goals.

The five outlined scenarios each hold their distinct advantages and disadvantages. Regardless of which of the scenarios turns out to be closest to reality, each respective scenario aims to achieve the same goal from an educational perspective: to provide autistic children with highquality education and allow them to develop to their full potential. That being said, these scenarios are aimed to open an honest and wide-ranging debate on how EU Member States should develop their education systems in the years to come without prescribing a definitive conclusion. They also do not consider economic and resource feasibility, population attitude, and national priorities.

Ultimately, it is the responsibility of each respective EU Member State to develop their education system. However, engaging in open dialogue and learning from the successes and mistakes of other EU Member States can prove to be invaluable to smooth the development process. When looking to translate a practice from another EU Member State, social, cultural, attitudinal, and policy factors should be considered and how these affect the practice in the original settings versus how these may affect the practice in the destination.

\section{Conclusion}

Despite the fact that autistic children and their families face many obstacles, allowing them to develop themselves in educational settings yields long-term benefits, even more so when the educational setting is inclusive in nature. However, the understanding and implementation of inclusive practices is still in its infancy. This thesis aimed to highlight key policy areas that could benefit the development of inclusive practices for autistic children by mapping autism and (special) education policies in EU Member States and synthesising the findings as part of the policy mapping project of EDUCAUS. While doing so, values of international documents such as the Universal Declaration of Human Rights and the Convention on the Rights of Persons with Disabilities were compared to national policy to see whether these values were integrated at a national level. 
The right to education for autistic children (and SEN in general) — set out by the UDHR, Convention on Rights of the Child, and Declaration on the Rights of Disabled Persons — was adopted by all regions $(n=30)$ under study. They unanimously created and implemented facilities and services that aim to aid children with various conditions to enjoy their right and access to education. The vast majority of countries $(n=28$; except Slovenia and the German community in Belgium) further developed their respective education systems according to the values of the Salamanca Statement and CRPD, which stress that children with SEN should be admitted to one single form of education: inclusive education. Subsequently, different factors that influence the development of (inclusive) education were investigated in the respective papers. Firstly, active parental involvement, while deemed valuable by literature for the development of inclusive systems for children with SEN, was limited. More specifically, parents rarely had influence on the actual approaches that teachers use to reach their child $(\mathrm{n}=2$; Finland and Flanders-Belgium $)$ and, instead, were found to play a more passive role in the majority of cases $(n=28)$ - being allowed to choose the school that their child would attend and subsequently be informed by the teacher on the progress on the child. Secondly, teachers were found to hold massive responsibilities on the education of children with SENeven more in comparison to neurotypical children. The identification of support services for teachers in many countries ( $\mathrm{n}=23$, of which 13 elaborate) can therefore be considered a positive finding of this research, especially given the beneficial effects that results from additional education for teachers. Thirdly, different forms of tensions were investigated, namely the tension that small states experience in implementing international guidance and the tension that may have risen when countries formerly part of the Soviet Union adopted the UN-based human rights ideology. On the topic of education, little tension was discovered in small states. All adopted services and approaches to enable children with SEN to follow education, though in terms of inclusion policies, they were found to be less elaborate. This finding was justified because of the comparatively smaller burden of disease that is experienced by these countries. The influences of the former Soviet Union were only noticeable in transition periods from the communist to the UN ideology. Afterwards, all policies were either amended or replaced by modernized versions that held the UN ideology as foundational framework. Finally, approaches to inclusion were found to widely differ across the EU-though seven common elements could be identified from these different approaches and used to identify trends. The introduction of mixed mainstream classes was indicated to be a critical factor in developing inclusion, while parental involvement and the 
respective absence of teacher support and a definition on inclusion were suggested as obstructive factors.

All this data helped us build a preliminary model for the development of inclusion and it is key that this model be further developed with data in- and outside of the EU in order to guarantee the education for autistic children globally. Currently, autistic children have access to education everywhere within the EU, though areas of improvement still exist.

Nevertheless, there is no sign of infringement of the right to education for autistic children. 


\section{References}

1. American Psychiatric Association. DSM-5 Autism Spectrum Disorder Fact Sheet. 2013. Available from: https://www.psychiatry.org/File Library/Psychiatrists/Practice/DSM/APA_DSM-5-Autism-Spectrum-Disorder.pdf

2. Roleska M, Roman-Urrestarazu A, Griffiths S, Ruigrok AN V., Holt R, van Kessel R, et al. Autism and the right to education in the EU: Policy mapping and scoping review of the United Kingdom, France, Poland and Spain. Jan Y-K, editor. PLoS One. 2018 Aug 30 [cited 2019 Apr 26];13(8):e0202336. Available from: http://dx.plos.org/10.1371/journal.pone.0202336

3. United Nations. Universal Declaration of Human Rights. 1948. Available from: http://www.un.org/en/udhrbook/pdf/udhr_booklet_en_web.pdf

4. United Nations. Declaration on the Rights of the Child. 1959. Available from: https://www.unicef.org/malaysia/1959-Declaration-of-the-Rights-of-the-Child.pdf

5. United Nations. Declaration on the Rights of Mentally Retarded Persons. 1971. Available from:

http://www.ohchr.org/EN/ProfessionalInterest/Pages/RightsOfMentallyRetardedPerso ns.aspx

6. United Nations. Declaration on the Rights of Disabled Persons. 1975. Available from: http://www.ohchr.org/EN/ProfessionalInterest/Pages/RightsOfDisabledPersons.aspx

7. United Nations Educational Social and Cultural Organisation. The Salamanca Statement and Framework for Action. Policy. 1994;(June):7-10.

8. European Commission. Treaty on the Functioning of the European Union. 2007. Available from: http://eur-lex.europa.eu/legalcontent/EN/TXT/PDF/?uri=CELEX:12012E/TXT

9. Council of Europe. European Convention on Human Rights. 1953 [cited 2018 May 1]. Available from: www.echr.coe.int

10. European Commission. Treaty of Amsterdam amending the Treaty on European Union, the Treaties establishing the European Communities and certain related acts. 1997 [cited 2018 May 3]. Available from: http://www.europarl.europa.eu/topics/treaty/pdf/amst-en.pdf

11. European Commission. Charter of Fundamental Rights of the European Union. 2000. Available from: http://www.europarl.europa.eu/charter/pdf/text_en.pdf

12. Autism-Europe. Charter for Persons with Autism. 1992. Available from: http://www.autismeurope.org/wp-content/uploads/2017/08/charter-for-persons-with- 
autism-1.pdf

13. European Commission. European Disability Strategy 2010-2020. 2010. Available from: http://eur-

lex.europa.eu/LexUriServ/LexUriServ.do?uri=COM:2010:0636:FIN:en:PDF

14. European Parliament. Written Declaration on Autism. 2015 [cited 2018 May 3]. Available from: http://www.autismeurope.org/wp-content/uploads/2017/08/writtendeclaration-on-autism-to-the-ep.pdf

15. The European Parliament, The European Council. GDPR - General Data Protection Regulation. Vol. 2014, Official Journal of the European Union. 2016 [cited 2018 May 31]. p. 20-30. Available from: https://eur-lex.europa.eu/legalcontent/EN/TXT/?uri=uriserv:OJ.L_.2016.119.01.0001.01.ENG

16. Hehir T, Grindal T, Freeman B, Lamoreau R, Borquaye Y, Burke S. A Summary of the Research Evidence on Inclusive Education. São Paulo: Instituto Alana; 2016. Available from: https://www.abtassociates.com/sites/default/files/201903/A_Summary_of_the_evidence_on_inclusive_education.pdf

17. United Nations Committee on the Rights of Persons with Disabilities. Convention on the Rights of Persons with Disabilities General Comment No. 4. 2016. Available from: http://www.ohchr.org/Documents/HRBodies/CRPD/GC/RighttoEducation/CRPD-CGC-4.doc

18. van Kessel R, Roman-Urrestarazu A, Ruigrok A, Holt R, Commers M, Hoekstra RA, et al. Autism and family involvement in the right to education in the EU: policy mapping in the Netherlands, Belgium and Germany. Mol Autism. 2019 Dec 9 [cited 2019 Dec 11];10(1). Available from:

https://molecularautism.biomedcentral.com/articles/10.1186/s13229-019-0297-X

19. van Kessel R, Walsh S, Ruigrok AN V., Holt R, Yliherva A, Kärnä E, et al. Autism and the right to education in the EU: policy mapping and scoping review of Nordic countries Denmark, Finland, and Sweden. Mol Autism. 2019 Dec 11 [cited 2019 Dec 14];10(1). Available from: https://molecularautism.biomedcentral.com/articles/10.1186/s13229-019-0290-4

20. van Kessel R, Dijkstra W, Prasauskiene A, Villeruša A, Czabanowska K, Brayne C, et al. Education, Special Needs, and Autism in the Baltic States: Policy Mapping in Estonia, Latvia, and Lithuania.

21. van Kessel R, Steinhoff P, Varga O, Breznoščáková D, Czabanowska K, Brayne C, et al. Autism and education-Teacher policy in Europe: Policy mapping of Austria, 
Hungary, Slovakia and Czech Republic.

22. Bunt D, Kessel R Van, Hoekstra RA, Czabanowska K, Brayne C, Baron-Cohen S, et al. Quotas, and Anti-discrimination Policies Relating to Autism in the EU: Scoping Review and Policy Mapping in Germany, France, Netherlands, United Kingdom, Slovakia, Poland, and Romania. Autism Res. 2020;13(8):1397-417. Available from: https://onlinelibrary.wiley.com/doi/full/10.1002/aur.2315

23. Department for Education. Special educational needs and disability code of practice: 0 to 25 years. 2015 .

24. Lai M-C, Lombardo M V, Baron-Cohen S. Autism. Lancet. 2013/10/01. 2014;383(9920):896-910. Available from: https://www.sciencedirect.com/science/article/pii/S0140673613615391?via\%3Dihub

25. Eurostat. Population change - Demographic balance and crude rates at national level. 2018 [cited 2018 Apr 30]. Available from:

http://appsso.eurostat.ec.europa.eu/nui/show.do?dataset=demo_gind\&lang=en

26. van Kessel R, Hrzic R, Czabanowska K, Baranger A, Azzopardi-Muscat N, Charambalous-Darden N, et al. Autism and the Influence of International Legislation on Small EU Member States: Policy Mapping in Malta, Cyprus, Luxembourg, and Slovenia.

27. Van Mieghem A, Verschueren K, Petry K, Struyf E. An analysis of research on inclusive education: a systematic search and meta review. Int J Incl Educ. 2018;1-15. Available from: https://doi.org/10.1080/13603116.2018.1482012

28. Education Endowment Foundation. Individualised instruction. 2019 [cited 2020 Jan 28]. Available from:

https://educationendowmentfoundation.org.uk/pdf/generate/?u=https://educationendow mentfoundation.org.uk/pdf/toolkit/?id=133\&t=Teaching and Learning Toolkit\&e $=133 \& s=$

29. Education Endowment Foundation. Digital technology. 2019 [cited 2019 Dec 24]. Available from:

https://educationendowmentfoundation.org.uk/pdf/generate/?u=https://educationendow mentfoundation.org.uk/pdf/toolkit/?id=134\&t=Teaching and Learning Toolkit\&e $=134 \& s=$

30. Johnstone C. The Role of Individualized Learning Plans (ILPs) in Inclusive Education. In: Inclusive Education Strategies: A Textbook. Minneapolis, MN, USA: University of Minnesota; 2018. p. 85-104. 
31. Kingdon JW. Agendas, Alternatives and Public Policies. Boston: Little, Brown and Company; 1984.

32. Walt G, Gilson L. Reforming the health sector in developing countries: The central role of policy analysis. Health Policy Plan. 1994 Dec;9(4):353-70.

33. Roberts J, Simpson K. A review of research into stakeholder perspectives on inclusion of students with autism in mainstream schools. Int J Incl Educ. 2016;20(10):1084-96.

34. Ruben B, Rigelman N, McParker M. Analysis of Stakeholder Perceptions of a Clinical Model Involving Co-Teaching and Extended-Field Experiences in an Inclusive Middle-Grades Setting. RMLE Online. 2016;39(6):1-18. Available from: http://dx.doi.org/10.1080/19404476.2016.1171571

35. Vlachou A, Papananou I. Experiences and Perspectives of Greek Higher Education Students with Disabilities. Educ Res. 2018;60(2):206-21. Available from: https://doi.org/10.1080/00131881.2018.1453752

36. Neiner JA, Howze EH, Greaney ML. Using scenario planning in public health: anticipating alternative futures. Health Promot Pract. 2004;5(1):69-79.

37. European Commission. White Paper on the Future of Europe. 2017 [cited 2020 May 6]. Available from: https://ec.europa.eu/commission/sites/betapolitical/files/white_paper_on_the_future_of_europe_en.pdf

38. Holmes EA, O'connor RC, Perry H, Tracey I, Wessely S, Arseneault L, et al. Position Paper Multidisciplinary research priorities for the COVID-19 pandemic: a call for action for mental health science. The Lancet Psychiatry. 2020 [cited 2020 Apr 17]; Available from: www.thelancet.com/ 


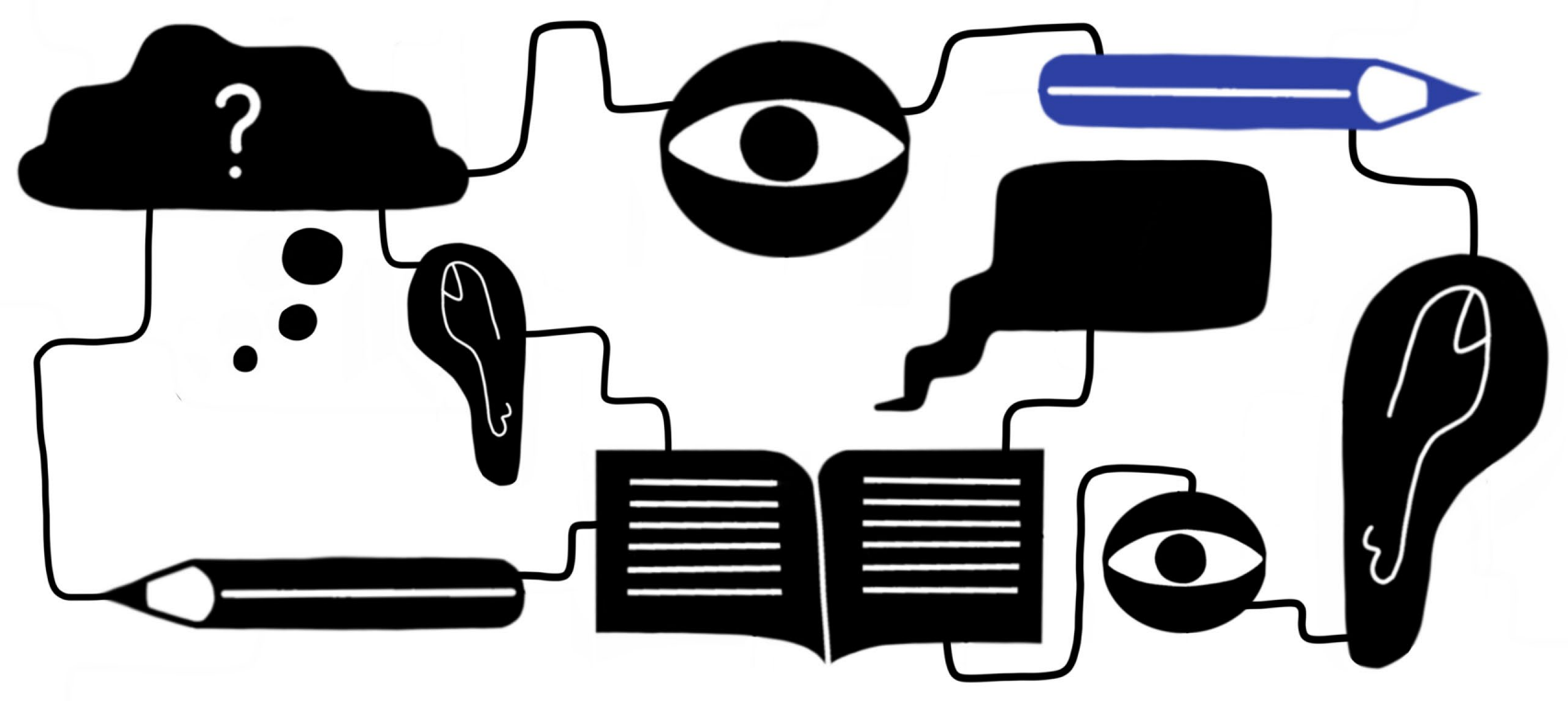

Summary 
One in 160 children globally has autism, causing an array of health and education needs throughout their life and being at risk for stigmatization, discrimination, and human rights violations. Inclusive education has widely emerged as a means to improve education for all children with special education needs, including autistic children. However, implementing inclusion is challenging, both in policy and practice, since systems of inclusion require the synthesis of mainstream and special education frameworks.

The focus of this thesis is analysing and describing education policy in the European Union (EU) covering 20 out of 28 Member States. The corresponding aim is to determine how the right and access to education for autistic children in the EU can best be improved, putting a particular focus on inclusive education.

This thesis discusses five Themes, namely (1) Right to Education; (2) Access to Education; (3) Support; (4) Tension; and (5) Trends. Each theme focuses on different (combinations of) chapters. Right to Education and Access to Education pool data from Chapters One through Five; Support from Chapters One through Three; Tension from Chapters Four and Five; and Trends from Chapter Six.

Right to Education examined the extent to which the right to education for autistic children was implemented in the twenty countries under study. It was found that all countries integrated the right to education for children with special education needs in general (thus including autism) in the early stages of the development of their education systems. Additionally, after the ratification of the Salamanca Statement and the Convention on Rights of Persons with Disabilities, a trend towards developing inclusive education was observed.

Access to Education focused on how education was developed and implemented for autistic children. All countries under study started with the implementation of different schools as to allow autistic children to follow education. Over time, most countries integrated autistic children that were able to participate in mainstream education into mainstream classrooms, while some fully delved in the development of inclusion systems, and a few retained their segregated systems.

Support looked into (1) the support autistic children receive from their parents; (2) the support parents of autistic children receive; (3) the support autistic children receive from 
teachers; (4) the support teachers receive in learning and understanding how to effectively address autism in a classroom; and (5) the support autistic children receive structurally. The role of family in mainstream education was generally limited to choosing the school in which a child will be admitted, while special education policy elaborated a bit more on the inclusion of parents, though that mostly involved the education of family.

Teachers, in their role in supporting children in mainstream education, were found to have been assigned massive responsibilities, which are raised even higher among autistic children. Teacher training curricula were also found to mostly include a course on SEN and autistic children were found to be able to receive additional provisions in classrooms.

Tension investigated two separate forms of tension, namely the tension that arises due to the difference in size of Member States when following international guidance; and the tension that arises from a change in ideology - in this case the change from the communist ideology harbored by the former Soviet Union to the UN human rights ideology.

Tension as a result of a difference in size is minorly present. International guidelines are implemented in large and small sized Member States alike. The observed difference was that larger Member States tend to have more elaborate policies on education and SEN, whereas small Member States tend to have more compact policies. Tension as a result of a changing ideology was found to primarily affect policies directly after the transition. In the investigated countries, the education policies that initially emerged after the adoption of the UN human rights ideology still held traces from the old, communist ideology, especially in regards to the education of autistic children (and children with SEN in general).

Trends examined patterns and trends that could point towards beneficial and obstructive factors for the development of inclusive education for autistic children. Seven factors were identified as being influential in the development of inclusive education, namely (1) the right to education for autistic children, (2) support for teaching staff, (3) general support services for autistic children, (4) individualized learning outcomes, (5) parental involvement, (6) an established definition of inclusion, and (7) mixed mainstream classes. From these factors, mixed mainstream classrooms and support services for autistic children were found to be key in allowing inclusion to develop, while inclusive education policies and teacher support were found to furthers enable the development of inclusion. 
The thesis concludes that, based on the performed analyses, the United Nations model that outlines the four educational approaches "exclusion, segregation, integration, inclusion" should be adjusted slightly as to better cover the children in the "integration" approach that cannot participate in mainstream education. Subsequently, based on the chronological analyses of the EU Member States and the identification of trends on the development of inclusion, five scenarios are drafted that outline possible future developments of education systems, some also considering the coronavirus pandemic. These scenarios aim to incite discussion on what factors should be focused on in the development of education systems and what outcomes should be prevented. Ultimately, this thesis adds a building block in the development of inclusive education for autistic children and, by extension, an improvement of the quality of life of the autism community moving forward. 


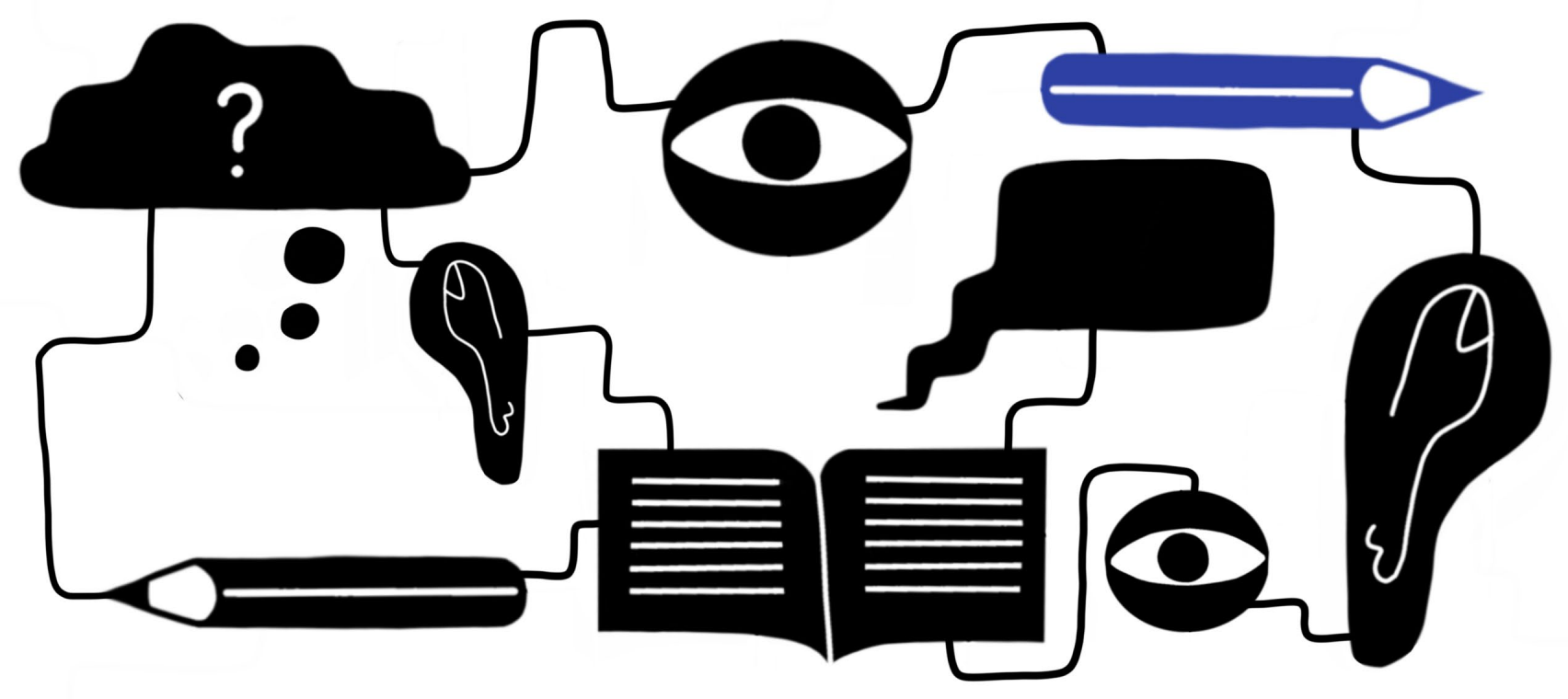

Acknowledgements 
During my $\mathrm{PhD}$, I had the opportunity to work with a lot of talented people and grow as both a researcher and as a person. This endeavor could not have been completed without the help and support of all the people I have worked with over the past years, to whom I would like to extend my gratitude.

Firstly, I want to thank my promotor Dr Katarzyna Czabanowska for her guidance and support during my journey, as well as her enthusiasm during our supervision meetings that helped encourage me to keep performing and pushing my limits. Secondly, I would like to thank my co-promotor Dr Andres Roman-Urrestarazu for his guidance, supervision, and patience, as well as for the opportunity and faith in me to take the lead in the EDUCAUS project. In terms of work ethic and quality, he was an inspiration to work with and I am grateful for the productive years we have had together. Thirdly, I would like to thank my former mentor Matt Commers. Our work together ultimately led me to the path in which I pursued a $\mathrm{PhD}$, for which I am beyond grateful.

I would like to convey my thanks and appreciation to the members of the assessment committee for their time reading critically through this dissertation and taking the effort to discuss it with me during the defense. I would also like to give a sincere word of thanks, respect and acknowledgement to the co-authors of the various papers for their valuable contribution, reviewing the drafts and their well wishes once papers were submitted.

Lastly, but definitely most importantly, I would like to thank my family and friends. I owe my sincerest thanks and appreciation to Marc Nijsten and Teun van Dam for their support in the form of reading drafts, listening to my concerns, or taking part in my enthusiasm, Ines Siepmann for challenging me in drafting the five scenarios and offering a different viewpoint, and Dewi Hombergen for her assistance in shaping the artworks for this thesis.

Thank you! 


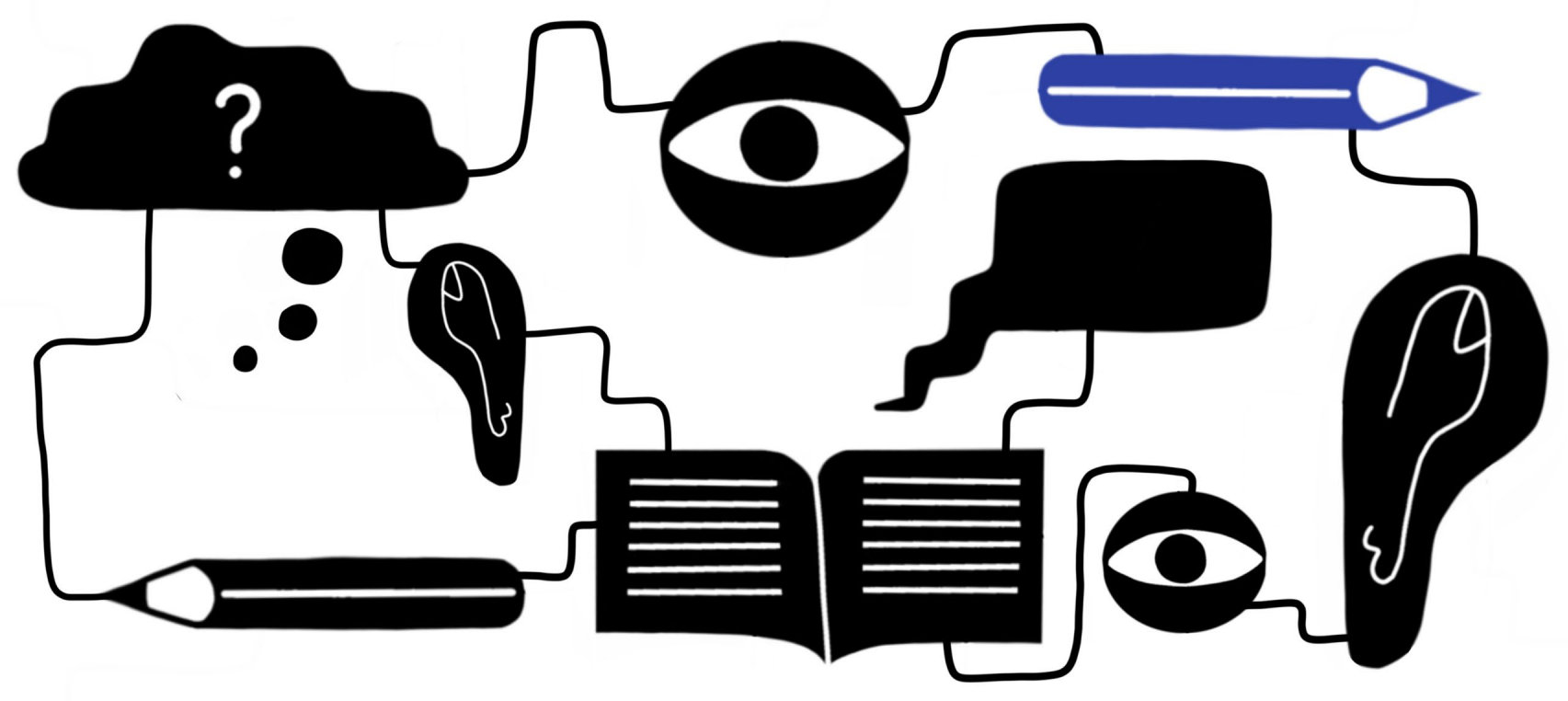

Curriculum Vitae 
Robin van Kessel was born 8 June 1996 in Urmond, Netherlands. He studied the Bachelor European Public Health (2014-2017) at Maastricht University, followed by the Master Governance and Leadership in European Public Health (2017-2018) at Maastricht University [Master thesis "Autism and family involvement in the right to education in the EU: policy mapping in the Netherlands, Belgium and Germany”].

After finishing his Master thesis in Cambridge, Robin worked as a research intern for the summer, after which he took the lead in the EDUCAUS education policy mapping project and made it his $\mathrm{PhD}$ subject. During his $\mathrm{PhD}$, he enriched his skillset by attending seminars, conferences, workshops, and courses and by mentoring and tutoring students in courses and writing their theses at Maastricht University. He also joined the COVID-19 Task Force that focuses on vulnerable groups of the Association of Schools of Public Health in the European Region (ASPHER). He assisted ASPHER in drafting a set of basic terms that pertain to vulnerable groups and broadcasting the 2020 Deans and Directors' Retreat on social media.

Currently, he is working as a post-doctoral researcher at the Department of International Health in Maastricht University. His prospective grant proposals involve projects that analyze and improve the infrastructure of teachers that work with children with special education needs. He is also expanding his field of research into health services for minority groups. 


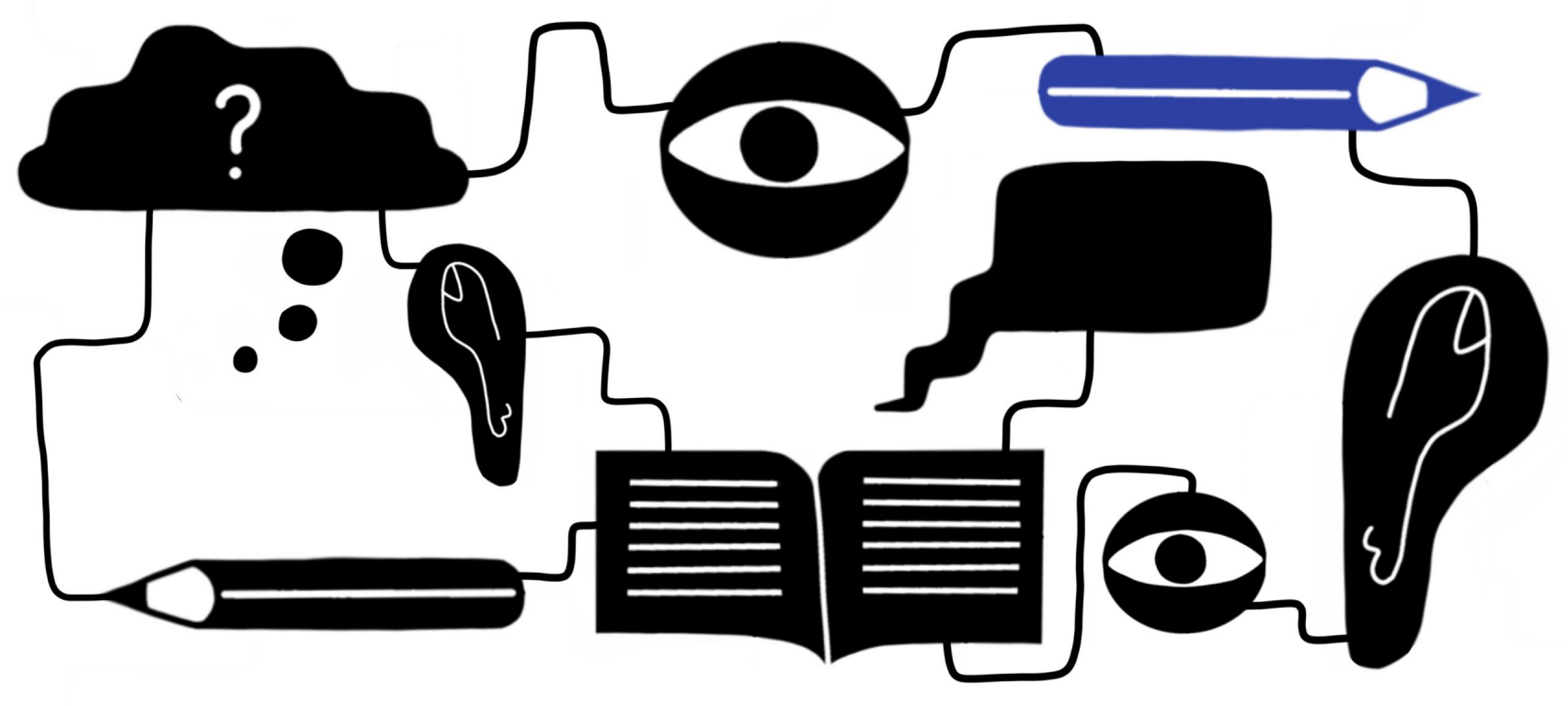

List of Publications 


\section{List of Publications}

*van Kessel, R.\#, Roman-Urrestarazu, A.., Ruigrok, A.N.V. et al. (2019). Autism and family involvement in the right to education in the EU: policy mapping in the Netherlands, Belgium and Germany. Molecular Autism 10. https://doi.org/10.1186/s13229-019-0297-x

*van Kessel, R.\#, Walsh, S.\#, Ruigrok, A.N.V. et al. (2019). Autism and the right to education in the EU: policy mapping and scoping review of Nordic countries Denmark, Finland, and Sweden. Molecular Autism 10. https://doi.org/10.1186/s13229-019-0290-4

*van Kessel, R.\#, Steinhoff, P.\#, Varga, O., Breznoščáková, D., Czabanowska, K., Brayne, C., et al. (2020). Autism and Education-Teacher Policy in Europe: Policy Mapping of Austria, Hungary, Slovakia and Czech Republic. Research in Developmental Disabilities 105(C). https://doi.org/10.1016/J.RIDD.2020.103734

*van Kessel, R., Hrzic, R., Czabanowska, K., Baranger, A., Azzopardi-Muscat, N., Charambalous-Darden, N., et al. (2020). Autism and the Influence of International Legislation on Small EU Member States: Policy Mapping in Malta, Cyprus, Luxembourg, and Slovenia. [Accepted and in press in European Journal of Public Health]

*van Kessel, R., Dijkstra, W., Prasauskiene, A., Villeruša, A., Czabanowska, K., Brayne, C., et al. Education for Autistic Children in the Baltic States: Policy Mapping in Estonia, Latvia, and Lithuania. [Accepted in Frontiers in Education]

*van Kessel, R., Hrzic, R., Cassidy, S., Brayne, C., Baron-Cohen, S., Roman-Urrestarazu, A., et al. Inclusive Education in the European Union: A Fuzzy-Set Qualitative Comparative Analysis of Education Policy for Autism. [Accepted in Social Work in Public Health November 2020]

Roleska, M., Roman-Urrestarazu, A., Griffiths, S., Ruigrok, A.N.V., Holt, R., van Kessel, R., et al. (2018). Autism and the right to education in the EU: Policy mapping and scoping review of the United Kingdom, France, Poland and Spain. PLoS ONE 13(8): e0202336. https://doi.org/10.1371/journal.pone.0202336

Bunt, D., van Kessel, R., Hoekstra, R.A., Czabanowska, K., Brayne, C., Baron-Cohen, S. and Roman-Urrestarazu, A. (2020). Quotas, and Anti-discrimination Policies Relating to Autism in the EU: Scoping Review and Policy Mapping in Germany, France, Netherlands, United Kingdom, Slovakia, Poland, and Romania. Autism Research 2020;00:1-21. Available from: https://onlinelibrary.wiley.com/doi/full/10.1002/aur.2315

Neicun, J.\#, Steenhuizen, M.\#, van Kessel, R.\#, Yang, J.C., Negri, A., Czabanowska, K., et al. (2019). Mapping novel psychoactive substances policy in the EU: The case of Portugal, the Netherlands, Czech Republic, Poland, the United Kingdom and Sweden. PLoS ONE 14(6): e0218011. https://doi.org/10.1371/journal.pone.0218011

Neicun, J.\#, Yang, J.C.\#, Shih, H.\#, van Kessel, R.\#, Nadella, P., Negri, A., et al. Lifetime prevalence of novel psychoactive substances use among adults in the USA:

Sociodemographic, mental health and illicit drug use correlates. Evidence from a populationbased survey 2007-2014. PLoS ONE 15(10): e0241056.

https://doi.org/10.1371/journal.pone.0241056 
Roman-Urrestarazu, A., van Kessel, R., Matthews, F., Allison, C., Brayne, C., and BaronCohen, S. Autism Prevalence in 7 million School Children in England: Ethnicity, Social Disadvantage and Access to Services. [Subject to major revisions and resubmission in JAMA Pediatrics November 2020]

Heine, E. , van Kessel, R.\#, Cassidy, S., Neicun, J., Gómez, J.L.C., Laszewska, A., et al. Organisation of Mental Health Services from an Autism Perspective: Policy Mapping in the United Kingdom, France, Spain and Poland. [Submitted to Health Policy October 2020]

vom Felde genannt Imbusch, P.\#, van Kessel, R.", Dragu, A., Brayne, C., Baron-Cohen, S., Czabanowska, K., et al. Europeanization and the right to education for autism: Policy Mapping and scoping review of Bulgaria, Romania and Croatia. [Submitted to Research in Developmental Disabilities October 2020]

van Kessel, R., Siepmann, I., Capucha, L., Brayne, C., Baron-Cohen, S., Czabanowska, K., et al. Autism, Austerity, and the Right to Education in the EU: Policy Mapping and Scoping Review of Ireland, Portugal, Italy, and Greece. [Submitted to Journal of Autism and Developmental Disorders October 2020]

\section{Conference Presentations}

INSAR Chile 2019

17-19 October 2019, Puerto Varas, Chile

van Kessel, R.: "Autism and the Right to Education in the European Union."

European Public Health Week 2020

11-15 May 2020, Brussels, Belgium (Online)

van Kessel, R., Roman-Urrestarazu, A., Czabanowska, K., Darden-Charambalous, N., Reid, J.: "Inclusion of Autism in Europe."

\section{Posters}

INSAR 2020 Virtual

van Kessel, R., Roman-Urrestarazu, A., Czabanowska, K.: "Autism and the Right to Education in the European Union." 